UNIVERSIDADE DE BRASÍLIA

INSTITUTO DE LETRAS

DEPARTAMENTO DE TEORIA LiterÁRIA E LiterATURAS

Programa DE PÓS-GRAdUaÇão EM LiteratuRA

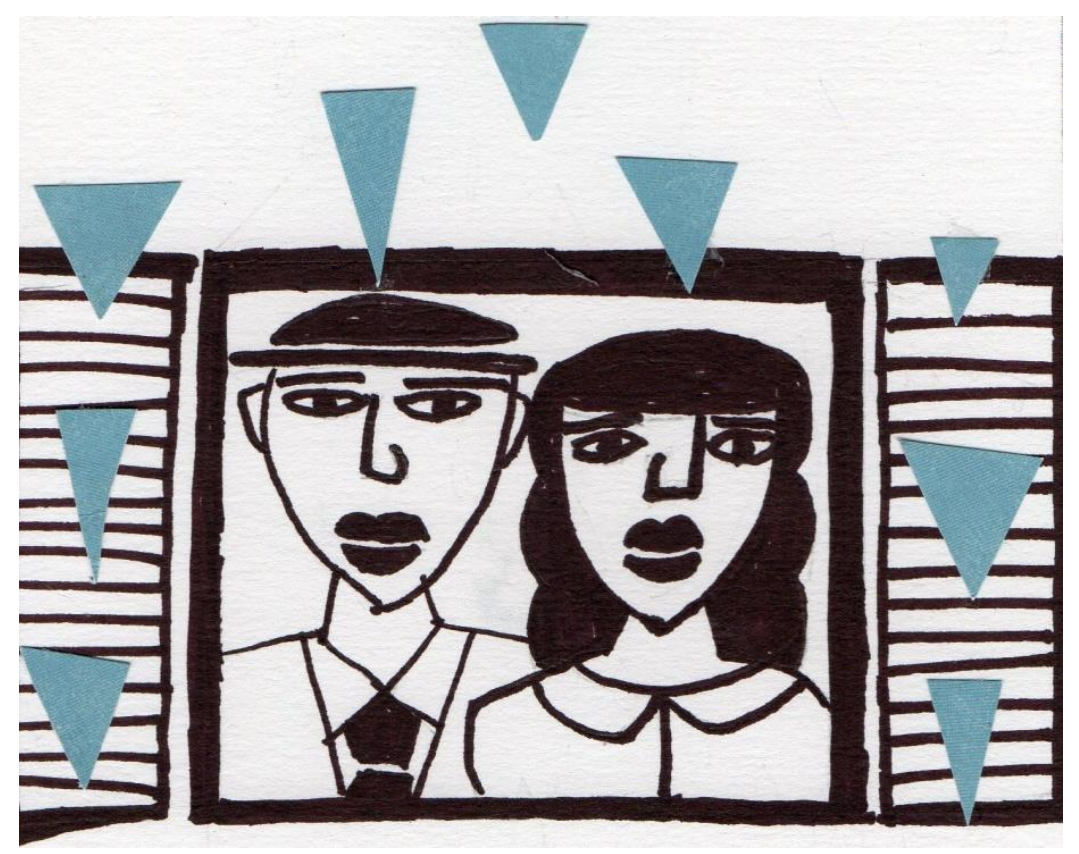

\title{
"É FÁCIL VER A CHUVA QUANDO VOCÊ NÃO SE MOLHA" os gabinetes da historiografia literária e do cordel e as poéticas a céu aberto
}

\author{
Bruna Paiva de Lucena
}

Orientadora: Prof ${ }^{\mathrm{a}}$. Dr ${ }^{\mathrm{a}}$. Regina Dalcastagnè

Brasília, março de 2016 
Tese apresentada ao Programa de Pós-graduação em Literatura do Departamento de Teoria Literária e Literaturas da Universidade de Brasília, como requisito parcial para a obtenção do título de doutora em Literatura.

Área de Concentração: Literatura e Práticas Sociais

Linha de Pesquisa: Representação na Literatura Contemporânea

Banca Examinadora:

$\operatorname{Prof}^{a}$. Dr ${ }^{a}$. Regina Dalcastagnè $(\mathrm{TEL} / \mathrm{UnB})$

(presidenta)

Prof. Dr. Anderson Luís Nunes da Mata (TEL/UnB)

(membro)

Prof. Dr. Eduardo de Assis Duarte (UFMG)

(membro)

Prof $^{a}$. Dr ${ }^{a}$. Gislene Maria Barral Lima Felipe da Silva (SEDF)

(membro)

Prof $^{\mathrm{a}}$. Dri ${ }^{\mathrm{a}}$. Virgínia Maria Vasconcelos Leal (TEL/UnB)

(membro)

Prof. Dr. Pedro Mandagará (UnB)

(suplente)

Prof $^{a}$. Dr ${ }^{a}$. Cíntia Schwantes (TEL/UnB)

(suplente) 
Para minha mãe, Madalena, que me deu "o de cumê", e para minha filha, Eleonora, a quem agora eu dou.

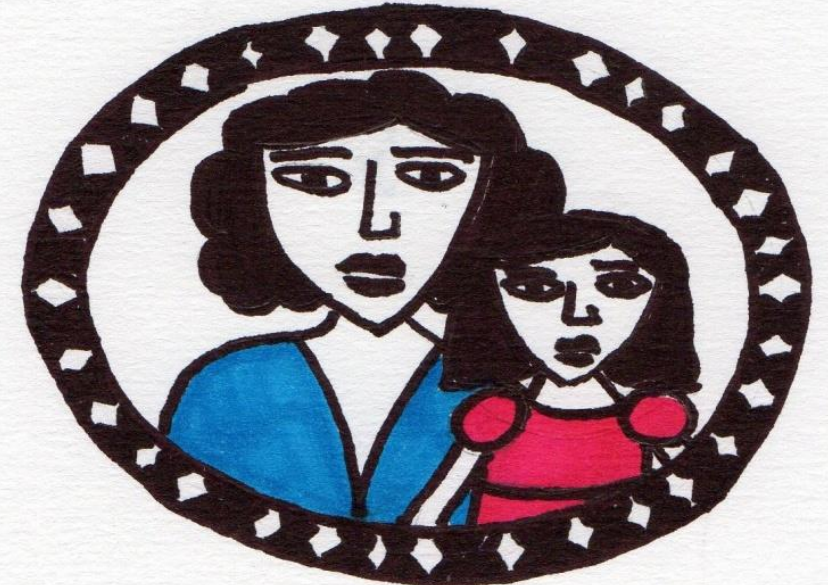




\section{AGRADECIMENTOS}

Ao iniciar o doutorado, já sabia que dentro de mim havia outro ser, que, ao mesmo tempo em que me pesava o corpo, me fortalecia a alma, na vontade de perseguir no caminho duro, de pedras, de tropeços, mas de caminhar intenso. Por isso, a esse ser, Eleonora, dedico esta tese, que só se fez inteira graças à minha maior inspiração, minha mãe, com quem pude inúmeras vezes contar no cuidado e afeto com minha menina, para que assim eu pudesse concluir esta empreitada que me colocou, muitas vezes, distante da cria.

Agradeço, ainda, à minha irmã, que, com seu profundo e terno olhar de encorajamento, me lembra para que viemos ao mundo, na nossa sina retirante de buscar vencer as secas da vida e de fazer valer o pau de arara que deu início à nossa história.

Um agradecimento especial à minha eterna orientadora, Regina Dalcastagnè, pelas suas provocações certeiras, pela leitura criteriosa desta tese e, principalmente, pelo convívio de mais de treze anos que me propicia aprender sobre o de dentro e o de fora dos muros da universidade. Agradeço, ainda, ao Grupo de Estudos em Literatura Brasileira Contemporânea, ao qual devo muitas das reflexões desta tese e do qual saíram Anderson Luís Nunes da Mata e Igor Ximenes Graciano, aos quais agradeço a leitura atenta da tese no momento da qualificação.

À minha amiga Francisca Pereira dos Santos, que me recebeu em sua aldeia com seu coração e arquivos abertos, e à professora Ria Lemaire, com quem pude conhecer uma história do cordel mais humana e sem preconceitos. Agradeço, ainda, ao gesto sempre generoso de Salete Maria da Silva, tornando sua obra acessível a todos e a todas, e à Sammyra Santana, por seu empenho na criação e manutenção do blogue Cordelirando.

À amizade, em especial às migas Renata e Sara, que me deram forças para seguir em frente entre uma xícara e outra de café, entre um choro e um riso.

Agradeço aos meus alunos e alunas, que todos os dias me instigam a tentar construir, juntos, mundos melhores. Um agradecimento especial, eterno e definitivo à escola pública, dentro da qual estou como estudante desde os quatro anos de idade e, 
como professora desse nosso Brasil profundo, há pouco tempo, que já se faz imenso em amor.

Agradeço, por fim, à Universidade de Brasília, onde cursei a graduação, o mestrado e o doutorado, à Coordenação de Pessoal de Nível Superior (Capes), pela concessão das bolsas de pesquisa em parte da graduação, do mestrado e do doutorado, e ao Ministério da Cultura (MinC), pela concessão de auxílio financeiro para a realização de pesquisa de campo no exterior. 
Eu perdi o meu medo da chuva.

Raul Seixas

Então é melhor falar tendo em mente que não esperavam que sobrevivêssemos Audre Lorde 


\section{SUMÁRI0}

\section{Introdução - Como quem faz uma colcha de retalhos: repensando a}

historiografia da literatura e do cordel brasileiros ............................................11

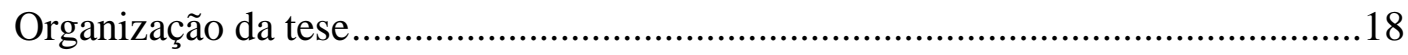

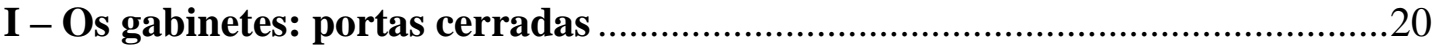

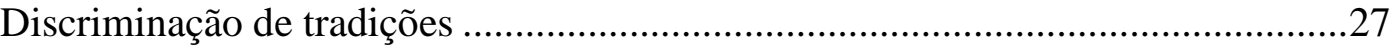

Levantando paredes: a construção da hegemonia e da legitimidade........................34

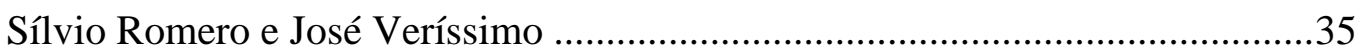

Afrânio Coutinho e Antonio Candido ......................................................................39

Os alicerces: pressupostos de dominação colonial.................................................48

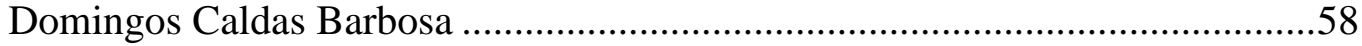

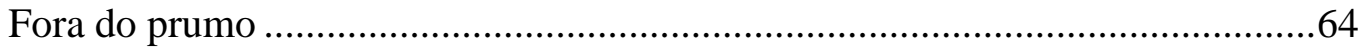

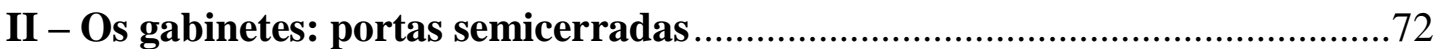

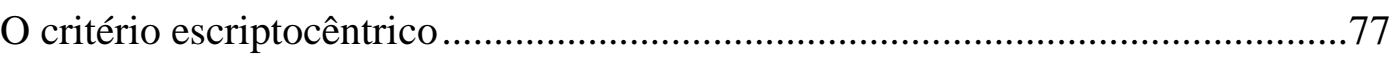

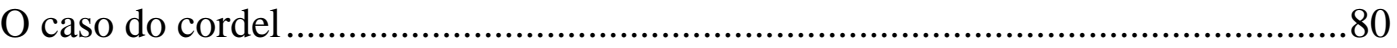

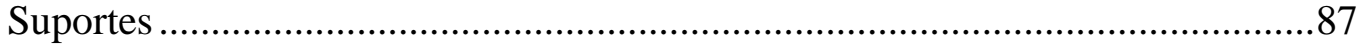

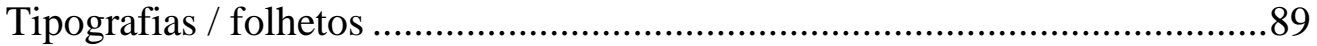

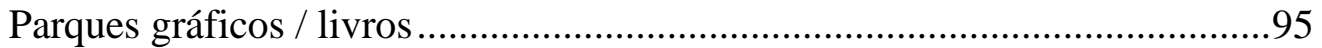

Internet /cordel digital ou cibercordel ....................................................99

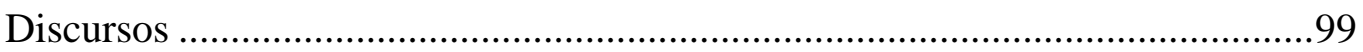

Fundação Casa de Rui Barbosa...................................................................102

Dicionário bio-bibliográfico de repentistas e poetas de bancada..................104

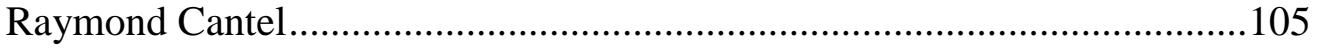

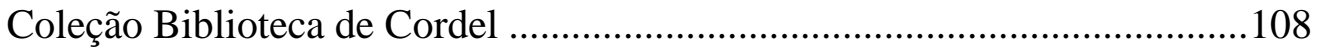

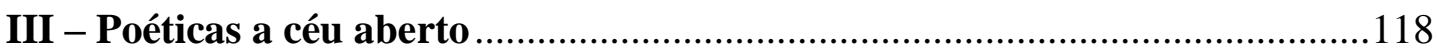

O céu é para todas: mulheres cordelistas .......................................................121

O deboche em Bastinha: submissão estratégica e desobediência tácita ............125

O impossível em Salete Maria da Silva..........................................................132

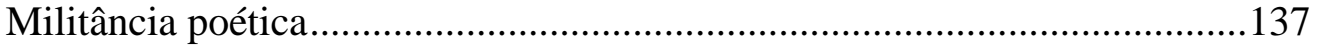

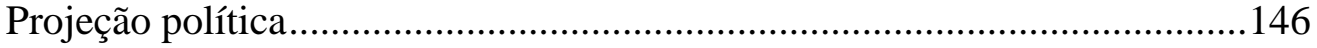


Considerações finais - Sob forte chuva: por historiografias à revelia dos gabinetes

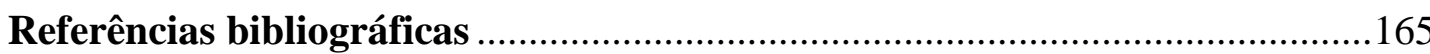




\section{RESUMO}

Esta tese insere-se em um rol de estudos que discutem a historiografia da literatura e do cordel brasileiros em um âmbito de revisão e questionamento de seus valores, parâmetros, paradigmas e métodos, com o intuito de trazer à tona tradições culturais que, por diversas circunstâncias históricas, sociais e ideológicas, não integram os estudos oficiais. Dado o caráter abrangente da abordagem, recortou-se um corpus representativo desse cenário, com obras paradigmáticas do contexto de produção da historiografia literária brasileira. O corpus de análise consistiu nas obras de Sílvio Romero, José Veríssimo, Afrânio Coutinho e Antonio Candido, e o do cordel, nas pesquisas da Casa de Rui Barbosa, de Átila Almeida e José Alves Sobrinho, de Raymond Cantel e da Coleção Biblioteca de Cordel da editora Hedra. Estabelecendo um quadro suplementar a esse corpus, foi estudada a obra do poeta Domingos Caldas Barbosa, que é considerada por essa crítica como menor, em razão de seus atributos orais e populares. A exclusão desse e de outros e outras poetas de nossa história literária é pensada por meio do cordel, empregado por Sebastiana Gomes de Almeida Job e Salete Maria da Silva, cujas obras são pensadas com base em teorias feministas e de gênero.

Palavras-chave: historiografia literária brasileira; estudos do cordel; mulheres cordelistas; Salete Maria da Silva; Sebastiana Gomes de Almeida Job. 


\begin{abstract}
This thesis is inserted in a list of studies that discuss the history of literature and Brazilian cordel in a sense of reviewing and questioning its values, parameters, paradigms and methods in order to bring out cultural traditions that, for various historical, social and ideological circumstances, do not constitute the official studies. Given the comprehensive nature of the approach, a representative corpus of this scenario was selected, consisting of paradigmatic works of the Brazilian literary history. The analytical corpus includes the works of Sílvio Romero, José Veríssimo, Afrânio Coutinho and Antonio Candido; in turn, regarding cordel, the corpus is composed by the researches developed in Casa de Rui Barbosa, and the works of Átila Almeida and José Alves Sobrinho, Raymond Cantel and from the collection Biblioteca de Cordel, published by Hedra. As a supplementary framework to this corpus, we analyzed the works of Domingos Caldas Barbosa, who is considered an inferior poet by the mentioned critics, due to his oral and popular attributes. The exclusion from our literary history of Barbosa and other poets is debated by Sebastiana Gomes de Almeida Job and Salete Maria da Silva, whose cordels are based on feminist and gender theories.
\end{abstract}

Keywords: Brazilian literary history; cordel studies; female authors of cordel; Salete Maria da Silva; Sebastiana Gomes de Almeida Job. 


\section{INTRODUÇ̃̃̃O}

Como quem faz uma colcha de retalhos: repensando a

historiografia da literatura e do cordel brasileiros

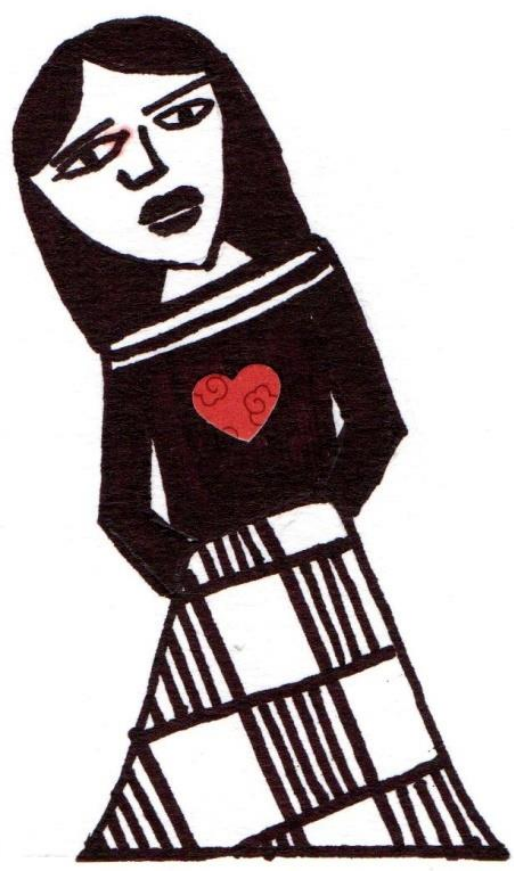


“É fácil ver a chuva quando você não se molha", escreveu Lucas Ramos de Oliveira, 17 anos, aluno de ensino médio, após ler o conto "O pão e a revolução", de Ferréz (2006), em que dois universitários questionam o dono de um bar, seu Donato, por ele ter dado um pão com manteiga e um pingado a um homem mancando com uma mancha no olho e um curativo no braço. Neste conto, são contrapostos os discursos acadêmico e os "da faculdade da vida", que, de acordo com o narrador do conto, "é mil grau", ao passo que o acadêmico é caracterizado como algo revolucionário, mas de uma revolução "que não veio até hoje", como afirma seu Donato. Entre o pão e a revolução, o narrador coloca-se a favor do pão, pois, como afirma Lucas Ramos, "é fácil ver a chuva quando você não se molha"1.

O conflito encenado nesse conto, entre teoria e prática, revolução e pão, discurso acadêmico e da vida cotidiana, quem vê a chuva e quem nela se molha, pode ser encontrado em diversos outros textos literários, em especial nos produzidos no âmbito do que se denomina de literatura marginal, periférica, popular ou oral, entre os quais se pode incluir o poema "Cante lá que eu canto cá", de Patativa do Assaré, em que são contrapostos os discursos do "poeta de academia" e do "poeta da mão grossa”. Neste poema, Patativa divide claramente dois universos culturais.

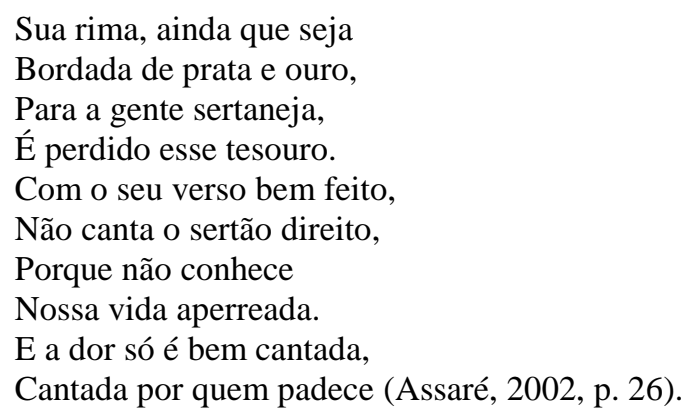

O debate empreendido por Ferréz e Patativa em seus textos é feito também pela cordelista Salete Maria da Silva, que, ao longo de sua obra, realiza críticas ao sistema social estabelecido. A cordelista propõe a combinação desses dois mundos, em uma práxis poética e política, ética e estética, colocando-se como alguém que vê a chuva e nela se molha, cuja posição social envolve, a um só tempo, carreira acadêmica e militância política, rejeição à classe média e aproximação à classe trabalhadora.

\footnotetext{
${ }^{1}$ As ilustrações constantes desta tese foram elaboradas pela autora.
} 
Patativa do Assaré coloca o poeta da roça e o da cidade em posições opostas, contrapondo-os em suas formas de ver e escrever o mundo. O posicionamento tomado por Patativa, segundo o qual "nossa vida é diferente / E o nosso verso também" (Assaré, 2002, p. 28), embora reforce o binarismo que fomenta os preconceitos entre esses espaços, constitui-se como estratégia de enfrentamento de um mundo que se sustenta inevitavelmente como binário em seus pressupostos e valores.

A estratégia empregada por Salete Maria da Silva é outra, ela revela os limites da lógica binária entre teoria e prática, militância e academia, e realiza uma poética que fala ao mesmo tempo do sertão e do asfalto, bem como traz questionamentos dessas duas realidades. Apresentando um contraponto não binário entre teoria e prática, ela dá sua contribuição a essa discussão mostrando, por exemplo, as dificuldades do êxodo de um espaço ao outro e da concomitância do rural e do urbano na existência de brasileiras e brasileiros que realizaram essa trajetória. A cordelista problematiza, ainda, as implicações desse movimento em uma escrita que apresenta apelo estético e militante, fruto de quem vive (e é espectadora) o mundo militante e o mundo acadêmico.

A narradora dos cordéis confunde-se com a própria cordelista, por narrar majoritariamente em primeira pessoa ${ }^{2}$ e trazer discussões que confirmam a posição política pessoal de Salete Maria da Silva. Diferentemente do que faz a cordelista Sebastiana Gomes de Almeida Job, que emprega uma linguagem matuta para trabalhar personagens presentes no imaginário cultural popular brasileiro. Salete Maria, por sua vez, constrói outros personagens e o espaço narrativo de sua obra traz ao mesmo tempo pão e poesia, realidade e ficção, configurando-se como um lugar de contestação ao discurso academicista que se desvincula da realidade. Ao afirmar-se no campo do cordel e da literatura como uma autora que vê a chuva e nela se molha, acadêmica e matuta, a cordelista estabelece seu espaço no cordel e contesta a hegemonia de uma tradição dessa poética.

\footnotetext{
${ }^{2}$ Dos 71 folhetos publicados por Salete Maria da Silva, apenas um é narrado por narrador matuto, Desabafo acadêmico matuto (1994). Nos demais cordéis, a voz narrativa é a da própria cordelista, que é escolarizada e preserva certo linguajar sertanejo.
} 
Salete Maria da Silva coloca-se na luta tanto pelas palavras quanto pela sua reverberação, posicionando-se estrategicamente em seu ângulo obtuso ${ }^{3}$, turvo, embaçado e escurecido pela forte chuva, mas que traz o sentimento, a sensação e a experiência de falar sobre a chuva, $d a$ e $n a$ chuva, com a chuva.

Em meio a esse território contestado, encharcado, escorregadio, pretendo discutir, com base em parte da historiografia literária brasileira hegemônica, a problemática da coexistência de diferentes tradições culturais em um campo literário que torna hegemônico e legitima determinados valores literários. Para isso, foi realizada a análise dos principais pressupostos teóricos dos críticos literários e historiadores da literatura: Sílvio Romero, José Veríssimo, Afrânio Coutinho e Antonio Candido. O que se buscou pensar, entre outros aspectos, foi sobre a extrema institucionalização das letras no Brasil e os impactos desse processo, como a eliminação de diversas formas de produção literária dissonantes das valoradas e legitimadas pela crítica.

Ao lado de obras literárias e da crítica institucionalizada pelo processo de construção da história de nossa literatura, há outros universos de criação poética cuja existência foi tornada opaca pelo grande relevo dado às produções hegemônicas, tal como a obra de Domingos Caldas Barbosa, também pensada nesta tese. $\mathrm{O}$ alçamento de determinadas obras e autores a canônicos não significou a dominação e eliminação desses outros universos, apenas a marcação de sua diferença, hoje tomada positivamente por autores marginais, periféricos e populares, como se tenta mostrar com a discussão sobre a obra da cordelista Salete Maria da Silva.

$\mathrm{Na}$ investigação dessas questões, observei que o processo histórico de colonização e o colonialismo configuraram-se como persistentes e enraizados no campo literário - tal qual sugere o conceito de colonialidade do poder desenvolvido por Aníbal Quijano (1992 e 2005) e rediscutido por Walter Mignolo (2003) -, e que, apesar de não serem a única causa da desvalorização literária, são uma das fortes concepções que fundamentam o processo de obliteração e subjugação das poéticas populares, uma vez que, embora o colonialismo tenha perdido o estatuto de centro

\footnotetext{
${ }^{3}$ Esse termo é aqui empregado no sentido dado pela própria autora em seu cordel Lugar de mulher, em que apresento um trecho a seguir: Do ponto onde me encontro/Na janela dum sobrado/Daqui donde me defronto/Com meu presente e passado/Fico metendo a colher/Do 'meu lugar de mulher'/Neste mundão desgarrado/Do meu ângulo obtuso/Num canto da camarinha/Afrouxo um parafuso/Liberto uma andorinha/Desmancho uma estrutura/Arranco uma fechadura/Desmonto uma ladainha/
} 
irradiador de valores e ideologias, estes foram em grande medida construídos com base em concepções coloniais, que fundamentaram a epistemologia que abaliza os julgamentos dentro do campo literário brasileiro.

No campo dos estudos do cordel ocorre movimento semelhante, que fundamentou um discurso historiográfico sobre o folheto e fixou um cânone nesse campo. Foi a política cultural desenvolvida, no Rio de Janeiro, pela Fundação Casa de Rui Barbosa, os estudos e a militância do pesquisador francês Raymond Cantel, as pesquisas coordenadas por Átila Almeida e José Alves Sobrinho, na Universidade Federal da Paraíba, que originaram o Dicionário bio-bibliográfico de repentistas e poetas de bancada, bem como o cânone historiográfico eregido pela Coleção Biblioteca de Cordel, da editora Hedra.

Rastreando os fundamentos epistemológicos que configuram a crítica da literatura e do cordel e confrontando algumas "ficções críticas" (Richard, 2002, p. 119), foi realizada uma investigação sobre os suportes do cordel, passando pela publicação do cordel em forma de folhas volantes e folhetos, pela importância das tipografias nordestinas nesse processo e pela crescente publicação de cordel em editoras e na internet.

O estudo das questões levantadas nesta tese seguiu uma sistemática que primeiramente me foi intuitiva e que só depois pude racionalizar e pensar realmente como metodologia de estudo. Como a pesquisa me é familiar desde a graduação, nunca tive medo da folha em branco e nunca temi a ausência de uma metodologia predeterminada. Ao pensar em sistemática e método de pesquisa, lembrei-se de minha avó materna, Otilina Paiva da Costa, que aprendeu a costurar roupas desmanchando roupas. Ela observava a estrutura do corte, da modelagem e da costura de cada peça, ao vê-la descosturada, e a recriava. Tornou-se mestra na arte de costurar, uma verdadeira Coco Chanel do sertão. Sempre considerei essa empreitada como uma prova da inteligência e perspicácia de minha avó, afinal, como se pode apreender o processo de feitura de algo mediante o seu desfazimento? Ao escrever esta tese, mais uma vez me aproximei de minha avó, senti-me como ela, no alto sertão baiano, descosturando uma peça de roupa bem costurada para apreender o seu modo de constituição. Foi por meio desse método que busquei pensar acerca de parte da historiografia literária brasileira e do cordel, desfazendo uma colcha de retalhos de discursos. 
É importante destacar que não se buscou provar a inviabilidade dessas ideias anteriores e se estabelecer um suposto radicalmente novo, mas pretendeu-se muito pelo contrário, a proposta era apropriar-se desses estudos anteriores e trabalhá-los criticamente, uma vez que, como afirma a filósofa Judith Butler (1998, p. 34), “desconstruir não é negar ou descartar, mas pôr em questão e, o que talvez seja mais importante, abrir o termo a uma reutilização e uma redistribuição que anteriormente não estavam autorizadas".

As obras de história literária estudadas nesta tese foram escolhidas com os objetivos de se obter uma visão geral do campo de forças que moveu e move a literatura brasileira e de se entenderem os sentidos construídos por essa crítica que constrói o que se costuma chamar de literatura, da instituição literatura. Em um primeiro momento, contrapuseram-se as visões de Sílvio Romero e José Veríssimo e, em um segundo momento, as de Afrânio Coutinho e Antonio Candido. Entre os excessos de repetições de um discurso sobre a literatura brasileira e de autores formadores dessa literatura, pude pinçar exceções. Inicialmente não julgava encontrá-las, contudo, quando me vi diante delas, julguei-as por sua pequenez e irrelevância, já que assim me foram mostradas pelos historiadores da literatura.

Um desses pequenos e desimportantes autores foi Domingos Caldas Barbosa, que com seus lundus deu prosseguimento à rica tradição oral em nossa literatura. Nascidas dois séculos depois de Caldas Barbosa, as cordelistas Sebastiana Gomes de Almeida Job e Salete Maria da Silva dão continuidade a essa outra história literária, sendo a apreciação de sua obra influenciada pelas ideias traçadas pela crítica hegemônica a respeito de seu colega de tradição - o que interliga essas poéticas, de alguma forma, em uma possível história literária da oralidade e do popular.

Nessa direção, repensar a história literária foi, ao mesmo tempo, assumir um legado cultural e questioná-lo, aprendendo a "colocar novas questões que possibilitem a revisão de ideias estabelecidas, das interpretações acerca destas ideias e das teorias decorrentes destas interpretações" (Lemaire, 1994). Além disso, repensar a história literária implicou repensar meu próprio lugar de fala dentro do universo da crítica literária que constrói esses discursos que formulam a historiografia literária. 
Ao adentrar nos gabinetes da literatura, desde que iniciei meus estudos acadêmicos na graduação em Letras, pude experimentar sentimentos paradoxais de aproximação e distanciamento em relação a tudo que me estava sendo apresentado. Vivenciei a experiência de estar diante de um mundo estranho e incompreensível, em um mundo que não me fez sentir em casa na maioria das vezes, seja pelas experiências existenciais desconexas de minha realidade ou pelas dificuldades formais impostas pela tessitura da obras que tive de ler e enfrentar. O sentimento desse desconforto acompanhou-me e acompanha-me até hoje quando se trata de minha tentativa de compreensão, e mesmo inserção, no mundo da literatura. Daí a necessidade de realizar um estudo negativo da crítica e da história literária, ou seja, uma reflexão crítica que não aceita a priori os esquemas, estruturas, valores e tradições literárias como linhas mestras para a explicação de todo o fenômeno do literário.

Os textos sobre os quais me debruço nesta tese não vieram das estantes das livrarias e ainda não estão nas mesas dos gabinetes das universidades. Meu contato com essa poética das vozes deu-se em meu núcleo familiar, que tirava das histórias de cordel as lições para as crianças, a piada para a roda de amigos e a notícia para o trabalho. O humor, na base de quase toda essa produção, é o tom adotado. A despeito de não serem muitos os folhetos na maleta dentro do guarda-roupa de quem os lê, eram e são muitas as narrativas em nossas mentes. Aprendemos essas histórias sem nem sentir, assim como os filhos da burguesia brasileira conhecem as principais obras da humanidade indo ao Louvre em suas férias escolares.

Mas não foi na varanda de meus avôs que tive conhecimento dos cordéis de Bastinha e de Salete Maria da Silva, autoras presentes nesta tese. Nem poderia ser, uma vez que, para os tradicionais leitores e ouvintes de cordel, essas obras parecem mais afrontar do que prestar tributo à sua tradição, tampouco me foram apresentadas nas cadeiras da universidade.

Em pesquisa de campo realizada em novembro de 2008, fiz uma imersão no Cariri cearense, graças ao afeto da querida Francisca Pereira dos Santos, e aí me foram apresentadas as vivas vozes de cordelistas, em especial as cordelistas Bastinha e Salete Maria. Nessa ocasião realizei pesquisas sobre a Academia de Cordelistas do Crato, na sede da instituição, e sobre a Sociedade dos Cordelistas Mauditos, acessando o acervo de memórias do grupo presente bo SESC Cariri. Em julho de 2014 dei prosseguimento à pesquisa de campo no Cariri, estendendo meus estudos ao 
Memorial Patativa do Assaré, e pude reencontrar as cordelistas Bastinha e Salete Maria em uma reunião de cordelistas na Universidade Estadual do Cariri.

Um livro divisor de águas nesse processo de mergulho na cultura do cordel foi Patativa poeta pássaro do Assaré (2002), do importante pesquisador Gilmar de Carvalho, que ganhei da querida amiga Edma Góis. Por meio dele, pude olhar para além do que falam sobre os poetas; com este livro pude escutar o que cada um dos poetas fala.

No meio do caminho, em dezembro de 2012, pude realizar importantes pesquisas para esta tese no acervo do Fonds Raymond Cantel de Littérature Populaire Brésilienne (Universidade de Poitiers - França), graças ao apoio do Ministério da Cultura (Brasil), mediante o Edital de Intercâmbio Cultural no 1/2012. Nessa ocasião tive acesso a um amplo acervo de cordéis e a importantes documentos sobre a obra de Cantel.

Estudar a obra de Salete Maria da Silva também foi fundamental para trazer minhas dúvidas e indagações, bem como meu universo literário, para o estudo acadêmico das letras. Com a obra da cordelista pude articular luta social, política e literária, embora ainda persista imenso preconceito em face de produções literárias militantes e interessadas, que, por esse e outros motivos, se desvinculam do circuito hegemônico da literatura. Estudar a obra de uma cordelista em um departamento de Literatura completa o círculo de democratização da universidade pública, que finalmente está sendo ocupada por estudantes que, como eu, são fruto da classe trabalhadora. E minha história é essa e não outra, e minha tese é essa e não outra, pois, como afirmou Boaventura de Sousa Santos (2003, p. 458), "temos o direito a sermos iguais quando a diferença nos inferioriza. Temos o direito a sermos diferentes quando a igualdade nos descaracteriza".

\section{Organização da tese}

No primeiro capítulo, busco refletir sobre as implicações da circunscrição dos estudos da historiografia literária aos paradigmas já estabelecidos sobre o literário. Esse processo levou ao estabelecimento de diferenças culturais, e caracterizou a cultura popular como residual à erudita e hegemônica, em um movimento de fixação de uma vantagem epistemológica estratégica das instâncias eruditas sobre a popular. Com o fim de investigar a institucionalização de determinado pensamento crítico, 
trago as ideias de Sílvio Romero, José Veríssimo, Afrânio Coutinho e Antonio Candido, que são alguns dos mais importantes críticos, historiadores e teóricos da literatura, cujas concepções se fundamentam, em alguma medida, em pressupostos de dominação perpetuados por nossa estrutura social colonial. Para pensar sobre a força hegemônica desses discursos e a exclusão que provocaram, analiso a obra de Domingos Caldas Barbosa, cujas proposições poéticas configuram uma espécie de submissão estratégica em face dos discursos hegemônicos e institucionais.

No segundo capítulo, há uma discussão sobre o processo de diferenciação e hierarquização de tradições culturais ligadas à oralidade e à escrita, que foi responsável por fixar a supremacia da cultura escrita e a deslegitimação da oral, mais tarde atrelada à cultura popular. $\mathrm{O}$ desenvolvimento e a institucionalização de intelectuais contribuíram para esse processo de desvalorização do popular, e a escrita serviu de paradigma para sua valorização cultural. Nesse contexto, toma-se a poética do cordel como paradigmática, especialmente no que tange a sua mobilidade em diferentes suportes - folha volante, folheto, livro, internet - , os quais, cada um a sua maneira, atribuíram a essa poética determinado valor simbólico. Além disso, realizase uma análise dos discursos sobre o cordel que fundamentaram uma concepção hegemônica dessa poética, ou seja, os estudos da Fundação Casa de Rui Barbosa, de Raymond Cantel e de Átila Almeida e José Alves Sobrinho, e a Coleção Biblioteca de Cordel, tal como se realiza no primeiro capítulo no que diz respeito ao contexto da literatura hegemônica.

O terceiro e último capítulo detém-se nas investidas de poetas da oralidade na configuração de seu espaço de produção. Para isso, analisa-se especialmente o contexto de produção de mulheres cordelistas, que passaram a ter expressiva participação no campo do cordel. Analisa-se parte da obra de Sebastiana Gomes de Almeida Job e de Salete Maria da Silva, que lidam de diferentes formas com a tradição do cordel e com as relações de gênero. 


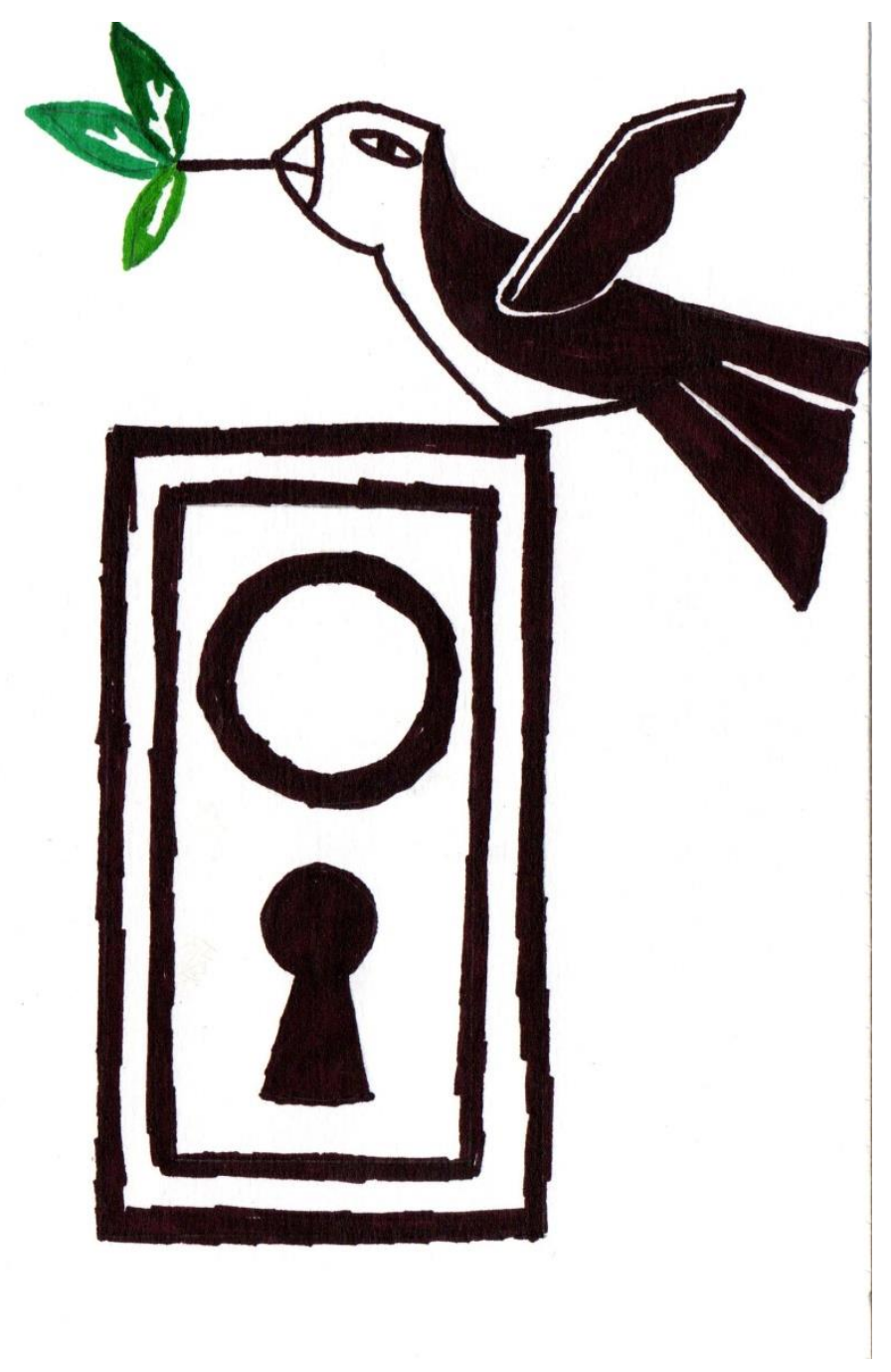

I _ OS GABINETES: PORTAS CERRADAS 
A Faculdade de Filosofia, Ciências e Letras criada na década de 30 do século passado na Universidade de São Paulo (USP) - que depois se tornou de Letras e Ciências Humanas - alicerçou uma série de paradigmas em torno do que hoje se considera a historiografia literária brasileira. Sua edificação foi, como afirma Sérgio Miceli (2011, p. 101), um dos instrumentos de luta política da oligarquia paulista, tendo-se em Antonio Candido um dos nomes que se edificaram nessa instituição e que a qualificou como "um projeto orgânico de instauração do saber por meio da reflexão e da investigação desinteressadas, isto é, não vinculadas imediatamente às exigências da formação profissional" (Candido, 2004, p. 221).

Nessa instituição, que foi a primeira da área no Brasil ${ }^{4}$, houve tanto a fixação de uma ideologia nacionalista quanto a importação de professores estrangeiros, ao tom da antropofagia de Oswald de Andrade. Entre esses docentes encontra-se o português Fidelino de Figueiredo, convidado para instituir um dos primeiros cursos superiores de Letras do Brasil e para ministrar um curso de literatura luso-brasileira. Aceitando o convite, o professor solicitou à USP, entre outras medidas, "a instalação de um gabinete de trabalho, indispensável ao exercício de seu tempo integral na instituição" (Amora, 1994, p. 423). O objeto desse pedido corriqueiro, de ordem burocrática, o gabinete, materializa, de alguma forma, o lugar de fala ${ }^{5}$ de grande parte dos críticos literários de literatura brasileira.

Desse espaço fechado, localizado no interior dos departamentos de literatura das universidades, são produzidas teorias sobre a literatura, bem como são interpretadas obras literárias. O silêncio e a solitude, necessários muitas vezes ao estudo e à escrita, são encontrados nesse espaço, onde também são debatidas questões relevantes à área. As obras que chegam ao gabinete do/a crítico/a - sendo levadas por ele/a ou sendo trazidas por outra pessoa - são geralmente as mesmas que constam das livrarias ou, especialmente, as que já estão catalogadas na sessão de

\footnotetext{
${ }^{4}$ Embora a Lei Saraiva, que permitia às mulheres o acesso aos cursos superiores, tenha sido criada em 1879, em 1934, quando foi criada a Faculdade de Filosofia, Ciências e Letras, poucas ingressavam nos cursos oferecidos, já que a maioria das mulheres estudavam nas escolas normais, que não eram voltadas para a preparação de candidatas aos exames de ingresso em universidades, mas sim para a habilitação ao magistério primário. $\mathrm{O}$ ingresso de mulheres condicionava-se, muitas vezes, ao estudo em escolas particulares ou com professores particulares. A Faculdade de Filosofia possibilitou o acesso de um número maior de mulheres oferecendo bolsas de estudo para as que já fossem professoras primárias. Uma das mulheres pioneiras da Faculdade de Filosofia foi Gilda de Mello e Souza.

${ }^{5}$ Aqui o termo lugar de fala refere-se genericamente ao espaço material e simbólico de produção de teorias e análises literárias.
} 
obras raras das bibliotecas. Os estudos sobre outras obras além dessas ainda são em número reduzido ao se pensar no montante total de produção da crítica literária. A hipótese que aqui lanço é a de que uma das razões da predominância de uma crítica literária centrada em reflexões sobre obras do cânone é o centramento de críticas/os no gabinete, ou seja, no espaço do institucional do acadêmico, fato do qual advém algumas implicações e, porque não ousar dizer, limites.

Diferentemente de outras práticas do campo das humanidades, como a sociologia e a antropologia, a crítica literária prescinde da realização de pesquisas fora dos gabinetes, sendo um trabalho sedentário quanto à busca de seu objeto, já que a única mobilidade do objeto é o próprio deslocamento do livro da estante das bibliotecas e(ou) livrarias para o gabinete. Esse deslocamento, contudo, é mediado, e mesmo determinado, por alguns elementos. Aqui será enfocada especialmente a mediação exercida pela historiografia literária hegemônica e, consequentemente, pelo cânone literário, na seleção do que é (e o que não é) objeto de estudo da crítica literária, mas poderiam ter sido analisadas outras mediações, como, por exemplo, a do mercado editorial hegemônico.

Do gabinete da historiografia literária, que se desdobra em outro gabinete, o do cânone, bem como a partir dos valores legitimados por essas órbitas, parte o olhar da crítica literária brasileira, que se vale dessa seleção prévia de obras ${ }^{6}$ e de valores para mais falar sobre essas mesmas obras ou sobre os mesmos gêneros literários já legitimados. Crítica essa que foi fortalecida no Brasil com a manutenção do “esquema curricular que se impusera a partir de 1880, em que, banidas a retórica e a poética, o ensino literário virou monopólio da história da literatura nacional" (Souza, 2013, p. 24); conforme salienta Márcia Razzini (2010, p. 53), “com a queda da Retórica e a ascensão da história literária nacional, a organização cronológica dos textos nas aulas de Português pareceu ainda mais legítima, sobretudo, depois da entrada da gramática histórica em 1890". O próprio conceito de "literatura nacional" traz em seu cerne a ideia de homogeneidade, de uma única literatura da nação.

Esse quadro alterou-se, segundo Souza (2013, p. 25), apenas a partir de 1962, com a reforma federal dos currículos de Letras em que se buscou distinguir a teoria literária da história literária nacionalista. Contudo, muito da teoria literária

\footnotetext{
${ }^{6}$ Vale ressaltar que a seleção feita pela historiografia relaciona-se à seleção feita pelas editoras,
} precedendo-a ou sucedendo-a. 
difundida nesses currículos fundamenta-se na história literária nacionalista até então contada, de modo que, embora haja um amplo painel da crítica e da história literária brasileira dos séculos XIX e XX, o que prevaleceu em grande parte dos cursos de Letras foi um discurso homogêneo.

O discurso presente nas universidades - e também no ensino básico -, além de homogêneo, é, na maioria das vezes, conservador e não reflete as recentes pesquisas realizadas na área, conforme defende Jaime Ginzburg:

\begin{abstract}
Existe um descompasso entre a pesquisa acadêmica em estudos literários e a situação do ensino universitário na área de Letras. Embora os últimos trinta anos tenham sido caracterizados por fortes discussões sobre paradigmas e modelos conceituais, os programas curriculares de Letras têm sido caracterizados de forma predominantemente conservadora, com poucas exceções (Ginzburg, 2002, p. 52).
\end{abstract}

As mudanças de paradigmas e modelos conceituais ocorridas nos últimos anos restringem-se, ainda, aos contextos das pesquisas das pós-graduações, não abrangendo os cursos de graduação e o ensino básico, muito em razão da forte resistência da academia às correntes de pensamento que adquiriram importância nos últimos tempos, como os estudos culturais e pós-coloniais, a posterior "virada etnográfica" e o feminismo acadêmico, na década de 1980 .

Os estudos de feministas e de gênero, por exemplo, cujas teorias provocaram descentramentos epistemológicos atestados por importantes teóricos da cultura e da literatura - tais como Terry Eagleton (2005, p. 128) e Stuart Hall (2003, p. 21), conforme aponta Virgínia Maria Vasconcelos Leal (2008, p. 115-116) -, são alvo de diversas formas de resistência pela academia e sociedade em geral (Schmidt, 2006), a despeito de seu crescente desenvolvimento.

Já em 1985, no Brasil, mais especificamente na Universidade Federal de Santa Catarina, é criado o Grupo de Trabalho "A Mulher na Literatura", da Associação Nacional de Pós-Graduação em Linguística e Literatura, o que marca a institucionalização dos estudos acadêmicos nessa área ${ }^{7}$. Como propõe Rita Terezinha Schmidt, a crítica feminista consiste em uma nova tradição de pesquisa

porque seus pressupostos e sua prática possibilitam uma intersecção de estratégias - política, pessoal, teórica, textual e filosófica - que fazem

\footnotetext{
${ }^{7}$ A Revista de Estudos Feministas, que iniciou suas publicações em 1992; os Cadernos Pagu, criados em 1993; e a Editora Mulheres, cujas primeiras obras foram publicadas em 1996, são outros marcos do fortalecimento da crítica literária feminista no Brasil.
} 
convergir, no ato e na cena da enunciação, vozes que não têm presença no discurso científico tradicional (Schmidt, 1994, p. 31).

Cabe aqui lembrar que, ainda em 1976, a crítica feminista Annette Kolodny escreve Dancing through the minefield, em que propõe importantes descentramentos epistemológicos ao âmbito dos estudos literários, a saber: a história literária é uma ficção, portanto, construída; os paradigmas de análise sobrepõem-se aos textos literários; o valor estético é construído, por isso nunca é infalível, imutável ou universal. Esses pressupostos impulsionaram transformações no discurso sobre a literatura, que vem paulatinamente abandonando um tom coeso, universalizante que permaneceu inabalado até os anos 1960 -, passando a ser mais plural, descentrado; assim como se observa um momento de questionamento à possibilidade de apolitização do literário, ainda arraigado no new criticism norte-americano, sendo evidenciado o caráter eminentemente político da literatura (Eagleton, 2006).

Além do impacto dos descentramentos epistemológicos provocados pelos estudos culturais e pós-coloniais, pela "virada etnográfica" e pelo feminismo, os estudos literários vêm sendo influenciados pelo desenvolvimento e pela visibilidade de uma diversidade de produções culturais e literárias vindas de contextos não hegemônicos, ou seja, de poéticas periféricas, marginais, de autoria de mulheres, negros(as), pobres etc. O crescente empoderamento e a militância de autoras e autores dessas poéticas têm possibilitado o questionamento de diversos pressupostos: de um único sistema literário, de uma única história e historiografia literárias, de um único cânone literário, de um único campo literário irradiador de valores ${ }^{8}$, entre outros. As escritoras e os escritores de minorias sociais, de caráter étnico, sexual ou de classe, têm estimulado questionamentos no campo literário no que diz respeito à adequação dos tradicionais paradigmas, métodos e categorias de análise. Soma-se a esse quadro de mudanças de paradigmas e valores, a insurgente presença de pesquisadoras e pesquisadores vindos também dessas minorias sociais, que propõem o redimensionamento de questões epistemológicas e metodológicas em seus campos de estudo, com base em sua experiência de vida e cultural também periférica, realizando, em alguns casos, desvios de olhares em outras direções.

Esse novo contexto de produção e de crítica literária questiona e desafia diretamente a crença arraigada nas teorias de arte de que a democratização dos meios

\footnotetext{
${ }^{8}$ A esse respeito, ver vídeo Chimamanda Adichie: O perigo da história única.
} 
de produção produziria uma arte massificada, homogênea. Alexis de Tocqueville, por exemplo, em A democracia na América, publicada em dois volumes (1835 e 1840), lança a seguinte indagação: é possível separar o movimento pela igualdade social e política do processo de uniformização cultural? Oswald Spengler, em A decadência do ocidente (1918), culpa, por sua vez, a democracia e a técnica pela degradação cultural das sociedades ocidentais. José Ortega y Gasset, em A desumanização da arte (1925) e A rebelião das massas (entre 1926 e 1927), demonstra ter a mesma preocupação de Tocqueville e Spengler. Ele defende que a massa é incapaz de produzir e consumir cultura. Em um contexto de adensamento de perspectivas críticas, mas ainda sob a influência de todos esses estudos, em 1947, Adorno e Horkheimer desenvolvem o conceito de indústria cultural, no conhecido livro Dialética do esclarecimento, que compreende que a emergência do que conhecemos como massa leva a intelectualidade a defender a manutenção de mecanismos de distinção na designação de obras de arte.

Como se pode perceber, a crítica de Adorno estabelece a existência de apenas um conceito de arte, de modo que as experiências artísticas e culturais que se afastam desse conceito são caracterizadas como sinônimo de decadência cultural e barbárie. O pensamento de Adorno e o de seus antecessores dão a ver a desconfiança, ou mesmo o temor, desses intelectuais frente à perda do controle sobre o que é e o que não é arte. Mais ainda, essa concepção denota a vontade de controle exclusivo de divulgação da arte.

Enquanto Adorno e seus pares acreditam que o privilégio da cultura é o que garante a sua vida, sendo a sua morte a democratização proposta pela indústria cultural, Daniel Bell, em O fim da ideologia, de 1959, defende o oposto. Para ele, a cultura de massa representa a democracia instaurada. Edwards Shils, autor de Mass society and its culture (1961), também partilha da mesma concepção, defendendo que a cultura de massa é a única que possibilita a comunicação entre diferentes grupos sociais. Para Bell e Shils, intelectuais e povo ocupam a mesma posição no consumo da cultura de massa.

A despeito do negativismo de Tocqueville, Spengler, Ortega y Gasset e Adorno e da extrema positividade de Bell e Shils quanto ao consumo de arte e cultura pelo povo-massa, o que é colocado por ambos os lados é a participação crescente do povo, mesmo que a contragosto de alguns, no universo de consumo do 
conhecimento. A esse respeito Michel Foucault, em conversa com Gilles Deleuze, postula o papel dos intelectuais em sociedades de massa:

\begin{abstract}
Ora, o que os intelectuais descobriram recentemente é que as massas não necessitam deles para saber; elas sabem perfeitamente, claramente, muito melhor do que eles; e elas o dizem muito bem. Mas existe um sistema de poder que barra, proíbe, invalida esse discurso e esse saber. Poder que não se encontra somente nas instâncias superiores da censura, mas que penetra muito profundamente, muito sutilmente em toda a trama da sociedade. (...). O papel do intelectual não é mais o de se colocar "um pouco na frente ou um pouco de lado" para dizer a muda verdade de todos; é antes o de lutar contra as formas de poder exatamente onde ele é, ao mesmo tempo, o objeto e o instrumento: na ordem do saber, da "verdade", da “consciência”, do discurso (Foucault, 2007, p. 71).
\end{abstract}

Como diz Foucault, a massa possui outras formas de acesso ao saber que não os dominados pelos intelectuais. Todavia, esses meios não são legitimados. $\mathrm{O}$ filósofo francês, para além da preocupação com o consumo do saber e da arte, denuncia a posição, muitas vezes autoritária, dos intelectuais como interditores da produção de outras formas de arte e saberes.

Muitas das obras periféricas, contudo, vão de encontro a esse entendimento de democratização da cultura como processo de massificação; e contrariamente ao postulado pelos detentores da definição de cultura, de arte e de literatura, apresentam-se como forma de afirmação do empoderamento por meio da arte, e não de subjugação.

Robert Muchembled, em Culture populaire et culture des elites (1978), liga a repressão que as culturas populares, desde os finais do século XVII, sofreram pela elite intelectual à postulação de que o povo é, em si, uma massa incapaz de produzir arte, estando essa crença arraigada em ideias de exclusão. Como Muchembled sugere, são formas de deslegitimar e inviabilizar a produção artística por parte do povo, tirando-lhe o ato de produzir e destinando-o apenas à posição de espectador. $\mathrm{A}$ massificação é trazida como argumento para invisibilizar a produção do povo.

Produções literárias periféricas, marginais, contudo, estão aí para mostrar que o povo não é apenas espectador e consumidor, mas produtor de sua própria cultura, também a inserindo na história e construindo outras histórias.

O empoderamento e a militância de minorias sociais juntamente com os descentramentos epistemológicos no campo da historiografia literária implicaram uma mudança de concepção quanto ao objeto literário, que, além de produto estético, passou a ser compreendido como produto cultural - aliás, o que sempre foi. 


\section{Discriminação de tradições}

A literatura brasileira formou-se com base em um discurso sobre a composição e a definição da nação brasileira, sendo essa concepção atestada por parte considerável da historiografia literária consolidada no século $\mathrm{XX}$, mesmo que em forma de negação a essa premissa. Ampla e permeável a diversos aspectos, a categoria nação construiu-se a partir da dialética do local versus universal, que consiste, de acordo com as ideias do crítico literário Antonio Candido (1997), na relação estabelecida, nos inícios de nossa literatura, entre as formas europeias já estabelecidas pelo Classicismo em âmbito europeu e as matérias locais pulsantes então em nossa sociedade. De acordo com Candido (1999, p. 14), o universal estaria mais atrelado à forma, e o local, ao conteúdo, havendo, entretanto, adaptação dessa forma "às necessidades de expressão dos sentimentos e da realidade local". Vale observar, contudo, que a dialética entre o local e o universal se apresenta, muitas vezes, de modo paradoxal. Como afirma Anderson Luís Nunes da Mata (2010, p. $43)$,

\footnotetext{
à dialética local versus universal falta a compreensão ampla do termo local, que pode ser ora visto como o nacional, ora como o regional, o que implica uma maior complexidade, já que o binômio pode ser lido facilmente como local versus nacional, levando a nacionalidade para a categoria das narrativas universalizantes.
}

A leitura da historiografia literária comprova que a cor local, elemento que teoricamente permitiria a incorporação de materiais alheios ao círculo elitista das belas letras, foi tomado apenas como subterfúgio para reverberar valores e paradigmas atrelados ao nacional, atrelado ao universal, entendido nesse contexto como europeu e de elite. Ao inserir e reinterpretar elementos da cultura popular brasileira, movimentos como o Romantismo ${ }^{9}$ apropriam-se das práticas populares e apresentam-nas como expressão da cultura erudita, havendo a transformação de algo local, popular, em algo erudito, dito universal. Passando pelas mãos de intelectuais, ligados à elite e à erudição, os elementos de cor local são traduzidos em nacionais e universais.

\footnotetext{
${ }^{9}$ No contexto inglês, é também o Romantismo o período no qual a noção de literatura, tal qual se concebe hoje começa a se desenvolver (Eagleton, 2006, p. 26).
} 
Além disso, o discurso da nação trouxe para nossa concepção de literatura critérios eurocêntricos e elitistas, mediante a repetição incessante de um discurso sobre o literário como parte unicamente de uma cultura europeia (apenas com fantasias brasileiras), pelas próprias obras literárias, pela crítica literária, pela historiografia literária, pelas teorias da literatura.

A repetição de valores e paradigmas advindos de um ambiente eurocêntrico e a concomitante legitimação desses ocorrem paralelamente à deslegitimação de outros valores e paradigmas, o que se dá mediante mecanismos de hierarquização presentes nesse processo entre o que tem valor, legítimo, portanto, e o que não tem, ilegítimo, por seu turno. São deslegitimadas, por exemplo, as literaturas populares ${ }^{10}$, alheias ao circuito das belas-letras. A distinção ${ }^{11}$ entre o entendido como popular em relação ao considerado erudito foi um dos mecanismos existentes nesse ambiente de fixação de um valor literário eurocêntrico e, por fim, elitista. Nesse sentido, são importantes os estudos de Robert Redfield (1969) e Peter Burke (1989).

O antropólogo Robert Redfield (1969, p. 41-42), ao se debruçar sobre a cultura camponesa, estabeleceu a existência de duas tradições culturais: a cultivada em escolas e templos e a cultivada nos lares e comunidades. Essas duas tradições o antropólogo denominou, respectivamente, de grande e pequena tradição. Da terminologia adotada pelo estudioso percebe-se forte visão hierarquizadora, à qual se soma a caracterização dessas tradições, respectivamente, como reflexiva (grande tradição) e irreflexiva e natural (pequena tradição). A desconexão estabelecida entre tradições contribui para a desconsideração da relação intercultural existente, nesse período, entre grande e pequena tradição, tal como ressalta Peter Burke (1989, p. 51).

Segundo Burke (1989, p. 17), por volta do ano de 1500, na Europa, podia-se presenciar a elite participando amplamente das culturas do povo e não exercendo nela sua força hegemônica. Contudo, vale frisar, apenas a elite podia transitar entre as duas tradições culturais - já que as portas das escolas e universidades somente a ela estavam abertas -; além disso, cada uma dessas tradições tinha uma função diferente, a grande tradição era séria, e a pequena ligada ao entretenimento (Burke,

\footnotetext{
10 A adjetivação de obras como popular dá-se no sentido desenvolvido em minha dissertação de mestrado, com base nos estudos de Ria Lemaire, em que defendi a ideia de que o termo popular designa uma tradição cultural e literária atrelada ao universo da oralidade. Cf. Lucena, 2010.

${ }^{11}$ A respeito dos mecanismos de distinção presentes no ramo das artes, ver Pierre Bourdieu (2007).
} 
1989, p. 55), o que já evidencia que entre a população essas tradições carreguem certo grau distintivo, mas não hierarquizador.

Pensando a relação entre direitos humanos e literatura no contexto cultural do final dos anos oitenta do século passado, o crítico literário Antonio Candido, em seu conhecido "Direito à literatura", reflete indiretamente sobre a questão das tradições culturais. Depreende-se claramente desse texto um posicionamento hierarquizador do que denomina de "níveis de cultura e de literatura", embora tente relativizá-lo dizendo que se deve respeitar "a fruição da arte e da literatura em todas as modalidades e em todos os níveis" (Candido, [1988] 2014, p. 191).

É importante destacar que, em todo momento, o crítico está pensando em termos de "fruição" e não de produção literária, havendo-se, ainda, a naturalização da divisão entre grande e pequena literatura e a supremacia da grande, em um contínuo evolutivo e hierarquizador. Por isso, a literatura prioriza alguns poucos nomes, preterindo outros, classificando-s como menores.

\begin{abstract}
Em nossa sociedade há fruição segundo as classes na medida em que um homem do povo está praticamente privado da possibilidade de conhecer e aproveitar a leitura de Machado de Assis ou Mário de Andrade. Para ele, ficam a literatura de massa, o folclore, a sabedoria espontânea, a canção popular, o provérbio. Estas modalidades são importantes e nobres, mas é grave considerá-las como suficientes para a grande maioria que, devido à pobreza e à ignorância, é impedida de chegar a obras eruditas (Candido, [1988], 2004, p. 186)
\end{abstract}

As tradições culturais, que originaram os diferentes "níveis de literatura", foram separadas hegemonicamente, conforme defende Peter Burke, quando, por volta de 1800, a elite - clero, nobreza, comerciantes, profissionais liberais - cessa de participar da pequena tradição, da cultura do povo. Esse movimento pode ser constatado com a alteração do sentido da palavra "povo", que passou a ser "usada com menor frequência do que antes para designar 'todo mundo' ou 'gente respeitável', e com maior frequência para designar 'a gente simples'” (Burke, 1989, p. 291).

A separação e a hierarquização de tradições culturais que se prolongam até a atualidade, tal como se pode perceber pela concepção de Antonio Candido, foram germinadas pelo Cristianismo, com a instauração da Inquisição, que teve, entre outros propósitos, a unificação do idioma, das festas, dos santos, bem como a condenação de superstições e de tudo mais que ameaçasse à constituição de um 
poder (cultural) central, segundo afirmam diversos estudiosos. Robert Muchembled (1978), por exemplo, debruça-se sobre a repressão que as culturas populares, desde os finais do século XVII, sofreram pela elite intelectual, e liga o processo de repressão ao processo de massificação cultural que tira do povo o ato de produzir e destina-o apenas à posição de espectador. Na mesma direção, tem-se Edward Palmer Thompson (1987), Peter Burke (1989) e Jacques Le Goff (1990).

No momento de hierarquização dessas tradições, começa-se a delinear a definição de cultura popular tal qual se observa atualmente, definida por meio de um conceito residual, nos termos de Burke; ou seja, em negação e oposição à cultura da grande tradição.

Encarando a literatura adjetivada como popular como uma das manifestações da cultura popular, pode-se estender a noção de residual para essa literatura, entendida por essas lentes como negação e oposição à literatura (sem adjetivos, por isso, obviamente, hegemônica). Esses movimentos de negação nem sempre são o que define uma literatura popular, que, muitas vezes, é prolongamento do hegemônico. A despeito de se tratar de prolongamento ou oposição do hegemônico, não só em termos de forma, mas também de conteúdo, as manifestações literárias populares são avaliadas e consideradas com base nos critérios estabelecidos a partir de manifestações literárias hegemônicas, já que delas advém o que se caracteriza como qualidade e valor literário.

Além de consideradas resíduos da grande tradição, as obras populares são analisadas, avaliadas e hierarquizadas com base nos paradigmas e valores atribuídos à literatura hegemônica, os quais são estabelecidos, reforçados e fixados por uma história, crítica e teoria literárias, além de pelas próprias obras literárias produzidas sob a lógica desses discursos. Roberto Acízelo de Souza afirma que a crítica

$$
\begin{aligned}
& \text { configura-se como integração de quatro instâncias solidárias: } \\
& \text { determinação do conceito de literatura; proposição de princípios e } \\
& \text { procedimentos para a análise de obras literárias; estabelecimento de } \\
& \text { critérios para a aferição do valor das produções literárias; consideração } \\
& \text { analítica de composições literárias, visando a estimativa de seus méritos } \\
& \text { estéticos (Souza, 2013, p. 14). }
\end{aligned}
$$

Analisar, valorar e disciplinar a literatura são ações realizadas não só pela crítica literária, mas também por instâncias discursivas a ela complementares - obra, historiografia e teoria literárias -, que corroboram à compreensão e à avaliação 
residual das obras literárias populares, sobrepondo seus pressupostos e valores aos dos dessas obras. A afirmação feita constantemente por críticos e teóricos de que a análise de uma obra é guiada primordialmente pelas proposições da própria pode até ser aplicável ao fazer historiográfico, crítico e teórico relativo a obras eruditas - caso se creia ingenuamente que é possível a supressão de ideologias no fazer crítico -, contudo, não se estende ao estudo de obras populares. Opera-se uma sobreposição do discurso das tradições cultural e literária erudita sobre as tradições cultural e literária popular, tidas como residuais em relação ao seu estatuto cultural e literário. Ao se produzir uma obra, se está estabelecendo, ao mesmo tempo, valores e paradigmas culturais e literários, que, no caso das tradições populares, são negligenciados em face da desvalorização de seus atributos constitutivos - rima, ritmo, repetição, improvisação, memorização, entre outros -, encarados como recursos pobres e menores, por exemplo. Como afirma Ria Lemaire (2011, p. 297) acerca do folheto de cordel,

permanece viva e atuante nesse campo de estudos a convicção de que é possível e legítimo estudar o folheto de cordel dentro da dicotomia que opõe a literatura do cânone à literatura popular, a superioridade daquela à inferioridade desta. É dentro dessa ordem pré-estabelecida que se privilegia o estudo do folheto impresso, numa abordagem que acentua o seu caráter escrito, sem levar em conta a sua produção, transmissão e recepção, baseadas numa ars poética diferente da da escrita, no canto, na declamação, na performance.

O discurso das instâncias eruditas da literatura tem uma "vantagem epistemológica estratégica"12, aproveitando os termos de Eduardo Viveiros de Castro, 2002, p. 115-117), sobre o das poéticas populares. Desenvolvendo um pensamento análogo ao de Viveiros de Castro, embora em um contexto distinto, podemos dizer que tradição cultural e literária hegemônica predefine e circunscreve a tradição cultural e literária popular, de modo que a alteridade desta tradição é radicalmente separada de sua capacidade de alteração. Assim, os gabinetes da literatura fecham-se aos discursos não hegemônicos, reafirmando continuamente seu próprio pré-discurso, qualquer que seja o objeto de análise. O fechamento aos discursos alheios, fundamentado em uma vantagem epistemológica estratégica

\footnotetext{
${ }^{12}$ Segundo Eduardo Viveiros de Castro (2002, p.115), “o antropólogo tem usualmente uma vantagem epistemológica sobre o nativo. O discurso do primeiro não se acha situado no mesmo plano que o discurso do segundo: o sentido que o antropólogo estabelece depende do sentido nativo, mas é ele quem detém o sentido desse sentido ele quem explica e interpreta, traduz e introduz, textualiza e contextualiza, justifica e significa esse sentido".
} 
apriorística, provoca o fechamento ao confronto e impossibilita a "mútua implicação"13 (Viveiros de Castro, 2002, p. 119) dessas tradições culturais e literárias tanto em termos formais quanto em termos conceituais, conforme atesta o crítico literário Antonio Candido:

\begin{abstract}
Com efeito, além da sua função própria de criar formas expressivas, a literatura serviu para celebrar e inculcar os valores cristãos e a concepção metropolitana de vida social, consolidando não apenas a presença de Deus e do Rei, mas o monopólio da língua. Com isso, desqualificou e proscreveu possíveis fermentos locais de divergência, como os idiomas, crenças e costumes dos povos indígenas, e depois dos escravos africanos. Em suma, desqualificou a possibilidade de expressão e visão de mundo dos povos subjugados (Candido, [1950] 2000, p. 11).
\end{abstract}

Embora Candido faça essa constatação acerca da subjugação de expressões distintas das oficiais e hegemônicas, o crítico reforça a inevitabilidade desse processo de distinção, naturalizando ao longo de sua obra as diferenças culturais e literárias (Candido, [1988] 2004) em nome da manutenção de um cânone fundamentado em valores estéticos. Contudo, não desistindo de defender a literatura como um espaço de humanização, Antonio Candido lista uma série de autores (de elite e da "grande" literatura) que ao longo da história empregaram temáticas ligadas ao povo para defendê-lo.

Em relação às implicações formais das tradições culturais e literárias hegemônicas e populares, diversos são os estudos que apontam a sua presença, especialmente no que se refere à utilização da cultura popular para a formação de uma arte erudita, mote, por exemplo, do Movimento Armorial erguido por Ariano Suassuna. No entanto, a relação estabelecida nesses casos caracteriza-se por uma inclusão do que já está incluído ideologicamente, ou seja, pela incorporação de elementos da cultura popular - encarada apenas como fonte de matéria-prima - que combinam e estão de acordo com a estética e os ideais da cultura erudita. Os materiais da cultura popular divergentes estética e eticamente da cultura hegemônica são desconsiderados, uma vez que se apresentam como uma outra representação do país e da cultura, sendo uma outra versão indesejada da história. Há um processo de elitização dessa produção.

\footnotetext{
${ }^{13}$ Para Viveiros de Castro (2002, p. 19), mútua implicação designa "a comum alteração dos discursos
} em jogo". 
Ao reinterpretar a cultura popular, movimentos como o de Suassuna apropriam-se das práticas populares e apresentam-nas como expressão de uma cultura julgada maior, a cultura erudita. Nesse processo, a presença de um intelectual ligado à elite e à erudição é extremamente necessária. É ele quem realiza o movimento que torna palatáveis à cultura hegemônica as culturas populares, que passam, segundo essa concepção, de particular para universal, ou, na pior das hipóteses, nacional.

Outro exemplo desse processo de "implicação unilateral" - na tentativa de formular um conceito análogo ao de "mútua implicação" desenvolvido por Viveiros de Castro - é a produção literária do Arcadismo, em que se emprega a temática indígena para a reafirmação da cultura erudita e não para a de uma possível cultura indígena. Esse movimento ocorre na literatura brasileira tanto em termos de fundação de uma literatura nativista - no Arcadismo - quanto de uma literatura nacionalista, cuja realização mais profícua aconteceu no Romantismo.

A "vantagem epistemológica estratégica" do discurso das instâncias eruditas e hegemônicas da literatura sobre o das poéticas populares resulta também, dentre outros fatores que poderiam ser apontados, da perpetuação de um discurso escriptocêntrico pela história e crítica literária, conforme defende Ria Lemaire (2007, p. 1):

\footnotetext{
por inacreditável que possa parecer, muitos estudos das tradições orais e populares, ou das literaturas provindas de outras eras ou civilizações, baseiam-se, eles também, numa convicção escriptocêntrica subjacente: a de que os conceitos, noções, métodos e teorias do discurso acadêmico contemporâneo podem servir para analisar, interpretar e avaliar qualquer texto, de qualquer época, de qualquer camada social e de qualquer região do mundo.
}

A vantagem estratégica do discurso da tradição cultural e literária erudita sobre a tradição cultural e literária popular impede que os pressupostos imaginados por cada uma dessas tradições entrem em relação. No entanto, houve iniciativas culturais que se fundamentavam em um hibridismo de linguagens e que promoveram o cordel, conforme ressalta o pesquisador Gilmar de Carvalho (2002b, p. 47), ao caracterizá-lo como uma "manifestação camaleônica apropriada por vários códigos", estando "no mangue-beat, nas pistas, sampleado ou com a batida tecno dos DJs; em Daúde cantando 'Vida sertaneja', de Patativa do Assaré, como um rap; num videoarte; num poema visual ou num grafite". 


\section{Levantando paredes: a construção da hegemonia e da legitimidade}

De acordo com José Veríssimo (1969), a crítica literária brasileira iniciou-se no ambiente das academias literárias vigentes no século XVIII e o trabalho dessa crítica consistia em elaborar "pareceres ou juízos [...] à pauta da retórica clássica" (Veríssimo, 1969, p. 270), o que se alterou em 1830, com o Romantismo, quando as obras eram estudadas com base em "indagações psicológicas e referências mesológicas históricas" (Veríssimo, 1969, p. 271), e também em 1870, com o Modernismo, momento em que, segundo o autor, a crítica revestiu-se de um espírito crítico.

Os textos "Revista Literária" (1859), de Bernardo Guimarães, "Da Crítica Brasileira" (1860), de Macedo Soares, e "O Ideal do Crítico” (1865), de Machado de Assis, são documentos em que já se pode visualizar uma "crítica para o desenvolvimento literário nacional” (Souza, 2013, p.19), ímpeto reforçado posteriormente, por nomes como José Veríssimo, em “A crítica literária” (1900), Sílvio Romero, em "Da Crítica e sua Exata Definição" (1909), e Medeiros e Albuquerque, em "A Crítica Literária" (1920). Ainda que esses autores tenham como foco unificador a ideia de uma literatura nacional, cada um entende essa literatura de forma distinta.

A centralidade de uma literatura nacional pode ser observada desde o desenvolvimento de uma crítica romântica, fundamentada, segundo Antonio Candido ([1950] 2000, vol. 1, p. 47), com as seguintes publicações: Minerva Brasiliense (1843 a 1845), Niterói (1836) e Guanabara (1849), as quais configuravam uma crítica de militância. Maria Eunice Moreira acrescenta a essas obras a polêmica em face da publicação do poema épico A Confederação de Tamoios (1856), de Domingos José Gonçalves de Magalhães, e a discussão entre José de Alencar e Joaquim Nabuco. Esse panorama, preponderantemente formado por textos de crítica literária, atesta que

a crítica praticamente precede a realização artística no campo da literatura, norteando os autores e aspirantes à carreira a se movimentar segundo a prescrição do discurso crítico. No caso brasileiro, é quase possível afirmar - ou é possível afirmar - que a crítica romântica "inventou" a literatura nacional, desconsiderando o autor e a obra que não se regesse por esse diapasão; no campo da política, colaborou para o 
nascimento de uma nação, firmando princípios que permitiram acentuar e definir a pretendida autonomia. (Moreira, 2013, p. 45).

Os critérios do considerado literário são, nesse sentido, construções ideológicas desenvolvidas em torno da ideia de nação e, também não se pode deixar de dizer, da escrita literária em língua padrão, das "belas letras". Ao analisar o contexto inglês dos século XVIII, Terry Eagleton observa que:

\begin{abstract}
os escritos que encerravam os valores e "gostos" de uma determinada classe social eram considerados literatura, ao passo que uma balada cantada nas ruas, um romance popular, e talvez até mesmo o drama, não o eram (Eagleton, 2006, p. 25).
\end{abstract}

Assim, o que se iniciou com a crítica literária oitocentista e se fundamentou com a crítica romântica, ou seja, a construção da história do Brasil e da literatura brasileira, foi sedimentado de forma inequívoca pela crítica literária realistanaturalista ${ }^{14}$, consubstanciada em grande medida por José Veríssimo e Sílvio Romero, bem como por autores que visaram posteriormente interpretar a história do Brasil e de sua literatura, tais como Antonio Candido e Afrânio Coutinho ${ }^{15}$.

\title{
Sílvio Romero e José Veríssimo
}

No início do século XX, Sílvio Romero despontou como um dos mais importantes intelectuais, e a sua polêmica ${ }^{16}$ com José Veríssimo movimentou e sedimentou, de alguma forma, a crítica literária brasileira. A rivalidade entre eles ocorreu tanto em nível teórico quanto em nível geográfico. A Escola de Recife, também denominada de Geração de 1870, da qual Sílvio Romero é integrante, fez frente ao suposto monopólio intelectual e cultural do eixo Rio de Janeiro e São Paulo, representado inclusive pela localização da Academia Brasileira de Letras no Rio de Janeiro.

Sílvio Romero publicou, em 1888, História da Literatura Brasileira - que republicou com diversas outras informações em 1902 -, obra fundamentada em uma

\footnotetext{
${ }^{14}$ A classificação da crítica realizada por José Veríssimo e Sílvio Romero como realista-naturalista foi feita por Luiz Roberto Cairo (1996), que também inclui nesse rol Araripe Júnior.

${ }^{15}$ Outros autores poderiam ser destacados, mas optou-se por esses - José Veríssimo e Sílvio Romero, Antonio Candido e Afrânio Coutinho - em razão de cada um desses pares representar orientações teóricas dissonantes e adversárias em seu posicionamento crítico em um dado período de tempo. Essa polarização foi fundamental, aliás, para a consolidação e a institucionalização da crítica literária brasileira.

16 João Cezar de Castro Rocha (2011a; 2011b) propõe a ideia de que a polêmica é um profícuo motor para o desenvolvimento da crítica literária brasileira.
} 
sociologia positivista e evolucionista e em uma ideia de literatura atrelada à cultura em sentido amplo, com base na noção de cultura na acepção alemã de kultur. Ao passo que José Veríssimo, um dos fundadores e presidente da Academia Brasileira de Letras, adotou uma visão de literatura essencialmente estética, fundada em julgamentos estéticos impressionistas, com base na noção francesa das belles lettres.

Em resposta à obra de Romero, Veríssimo lançou, em 1916, sua História da Literatura Brasileira; e o uso do mesmo título de Romero é "como se Veríssimo afirmasse: eis, de fato, uma história da literatura brasileira, em lugar de um catálogo da 'literatura' brasileira.” (Rocha, 2011a, p. 108).

Embora Veríssimo adote visão de viés estético no estabelecimento de uma periodização literária, ele emprega critério histórico-político, dividindo a literatura em período colonial e nacional, dicotomia que tem por base a ideia de autonomia em relação à colônia portuguesa - consequentemente à literatura portuguesa - e de formação de um sentimento nacional.

Sílvio Romero realizou, de modo geral, um trabalho de síntese e de generalização, com muito apego classificatório e metodológico, com base nas obras de críticos como Francisco Adolfo de Varnhagen, Joaquim Norberto de Sousa e Silva e João Manuel Pereira da Silva, dos quais adota o tom nacionalista e utiliza o enorme acervo que formou com suas antologias. Já Veríssimo seguiu um tom subjetivista, de opinião, impressionista, e fez uma crítica que se diz desinteressada de questões externas, com base, principalmente, nas ideias do crítico e historiador francês Hippolye Taine.

Romero e Veríssimo, com todas essas dissonâncias, propõem diferentes concepções de literatura. Para Sílvio Romero (1888, p. 4),

a expressão literatura tem a amplitude que lhes dão os críticos e historiadores alemães. Compreende todas as manifestações da inteligênciade um povo: política, economia, arte, criações populares, ciências..., e não, como era de costume supor-se no Brasil, somente as intituladas belas-letras, que afinal cifravam-se quase exclusivamente na poesia!

Já para Veríssimo (1916, p. 9),

literatura é arte literária. Somente o escrito com o propósito ou a intuição dessa arte, isto é, com os artifícios de invenção e de composição que a constituem é, a meu ver, literatura. Assim pensando, quiçá erradamente, pois não me presumo de infalível, sistematicamente excluo da história da literatura brasileira quanto a esta luz se não deva considerar literatura. Esta é neste livro sinônimo de boas ou belas letras, conforme a vernácula 
noção clássica. Nem se me dá da pseudonovidade germânica que no vocábulo literatura compreende tudo o que se escreve num país, poesia lírica e economia política, romance e direito público, teatro e artigos de jornal e até o que se não escreve, discursos parlamentares, cantigas e histórias populares, enfim autores e obras de todo o gênero.

Percebe-se claramente que o conceito de literatura proposto por Veríssimo é uma negação ao formulado por Romero, para o qual as letras se referem a qualquer texto (oral ou escrito) representativo da cultura brasileira, e não somente a textos escritos considerados literários.

A importância da obra para Romero reside em seu valor social, nacional, sendo secundário o valor estético; de modo que a literatura atrela-se à cultura oral e escrita e é valorada com base em critério sociológico. Ao avaliar a relevância cultural das produções artísticas e culturais, o crítico considera a ação do clima sobre as populações; a formação e a origem racial do país; o folclore, e a cultura como um todo, e sua gênese; observando, ainda, a influência estrangeira sobre nossa produção cultural. Veríssimo, por sua vez, privilegia o estético, sendo o valor literário medido por essa balança.

De acordo com Antonio Candido (1988, p. 12 e 14), Sílvio Romero permaneceu em nossa historiografia como um marco fundador da moderna crítica literária brasileira e um respeitável intérprete de nosso processo cultural, mas foi José Veríssimo, juntamente com Araripe Júnior, que fez "mais trabalho de crítica propriamente dita", visto que realizou a tarefa de análise de obras sob um viés estético. Com argumento semelhante ao de Candido, Letícia Malard (2013, p. 113) defende que "Veríssimo deu um passo importante em relação a Romero, quando ressaltou o julgamento estetizante de obras".

Em razão da primazia do estético em sua abordagem teórica, Veríssimo não dá crédito ao lugar ocupado por Romero na historiografia, conferindo a Varnhagem o título de fundador da história literária brasileira, todavia, Sílvio Romero avulta como um dos primeiros estudiosos a voltar-se à construção de uma história das produções artísticas do povo brasileiro, entendendo-se povo como uma categoria ampla e permeável a diversas classes, etnias, tendo seu trabalho o caracterizado como um folclorista, categoria malvista pelos estudos acadêmicos. 
A diversidade a que se abre o trabalho de Romero, contudo, serve à afirmação de um ideário mais uma vez eurocêntrico. Ainda no século XIX, Sílvio Romero, juntamente com o médico Nina Rodrigues e Euclides da Cunha, foram os estudiosos que buscaram na raça a origem das particularidades de cada nação e a construção de uma ideologia nacional, bem como as raízes da formação do povo brasileiro, tendo obviamente como ponto de referência o nacionalismo europeu, que servia como paradigma de compreensão e de valoração de nossa cultura (Ortiz, 1986). Assim, a ligação vista por muitos autores entre o nacional e o popular evidenciada, por exemplo, na afirmação de Nelson Werneck Sodré (1998, p. 88) de que "só é nacional o que é popular" e nas pesquisas de intelectuais como Gilberto Freire e Mário de Andrade - é tomada apenas em relação à cultura brasileira em sentido amplo, não se referindo à literatura, que é concebida como criação de uma elite que abstrai os elementos do popular e do nacional em sua produção literária. Além disso, Romero acaba por defender uma identidade brasileira e não multiplicidades de identidades, de modo que a potência de diversidade que sua visão de literatura teoricamente poderia criar é solapada por uma ideia de identidade brasileira, fixada, em grande medida, para responder aos anseios eurocêntricos.

Ao considerar todas as "manifestações da inteligência de um povo" (Romero, 1888, p. 4) como literatura, e não formular uma especificidade mínima que identifique um texto (oral ou escrito) como literário, Romero acaba sendo descaracterizado como crítico e historiador literário e sendo definido como um estudioso da cultura, o que, de forma alguma, é um problema, mas que carrega uma longa história de distinção entre aqueles que estudam estritamente "a literatura escrita", da universidade, e aqueles que estudam "as tradições populares e orais", designados como folcloristas, conforme atesta Ria Lemaire (1994).

Contudo, isto inviabilizou o prosseguimento de suas concepções de texto e de literatura pela crítica literária brasileira hegemônica, que se assentou em uma concepção de literatura ligada ao escrito e ao valor estético hegemônico, conforme, por exemplo, os estudos de José Veríssimo, a despeito do grande nome de Sílvio Romero no universo das letras.

A dissensão entre Romero e Veríssimo prolonga-se pela história de nossa crítica literária chegando até, por exemplo, aos críticos Antonio Candido e Afrânio Coutinho, que, segundo Flora Süssekind (1993, p. 21) duelam, e que se diferem em 
relação a vinculações institucionais, teóricas e políticas, embora Candido adote uma postura mais moderada, comparando-a com a de seus pares, visto que tanto declara sua "dívida" em relação à História da Literatura Brasileira de Silvio Romero e à Pequena história de Ronald de Carvalho como também ressalta a importância da História da Literatura Brasileira de José Veríssimo (Candido, [1950] 2000, p. 11).

No cenário da crítica literária brasileira de meados do século $\mathrm{XX}$, temos, de um lado Candido, representante da Universidade de São Paulo (USP), e, de outro lado Coutinho, da Universidade Federal do Rio de Janeiro (UFRJ); respectivamente um crítico politicamente mais à esquerda, que firma sua posição sobre a ideia de nação com base em método histórico-sociológico, e o outro mais à direita, que adota concepção esteticista para compreender o fenômeno literário.

\section{Afrânio Coutinho e Antonio Candido}

Afrânio Coutinho contrapõe sua A literatura no Brasil (1955 a 1959), da qual é organizador, nitidamente à de Silvio Romero, e apesar de o texto "O escritor e o público" de Antonio Candido integrar o primeiro volume dessa obra, Coutinho faz frente à crítica feita pelo estudioso da USP, ao condenar o método histórico que, segundo ele, "é complacente com os autores medíocres, sob o pretexto de que esclarecem e explicam os contemporâneos" (Coutinho, 1986, vol. 1, p. 7), e ao fazer frente à "tirania sociológica” e à "tirania política” (Coutinho, 1980, p. 34).

Coutinho diz: "o essencial é o estudo da obra em si mesma. Esta deve ser a finalidade suprema do estudo literário, isto é, da crítica" (Coutinho, 1986, vol. 1, p. 9), de modo que a avaliação de uma obra deve ser feita com base no julgamento e na valorização do estético, que é autônomo em relação ao contexto histórico social. Embora haja extremismo do estético em sua concepção literária, Coutinho faz uma crítica importante ao apego da historiografia literária às instituições nacionais e ao espírito nacional como definidores da literatura brasileira. De acordo com Coutinho (1986, vol. 1, p. 74), a literatura

\footnotetext{
é o produto da imaginação criadora, artística, é uma forma de arte, a arte da palavra, cuja finalidade é apenas despertar o prazer estético. Conforme essa concepção, tudo aquilo que, produto do espírito humano, tenha por objetivo ensinar, informar, dirigir a opinião, estudar o passado, investigar o presente social, está fora da literatura.
} 
O conceito de literatura desse crítico assemelha-se ao de José Veríssimo e distancia-se, em sobremaneira, do de Sílvio Romero, especialmente no que se refere à abrangência da literatura, que para Coutinho se atrela unicamente ao fenômeno estético do texto literário, uma vez que a obra deve visar ao prazer estético e ser construída com base em gêneros, cânones, convenções preestabelecidos.

Coutinho inseriu-se no mundo das letras como um militante da crítica literária e, apesar de reunir diversos intelectuais para a construção da grandiosa obra que idealizou, cultivou desafetos com seus posicionamentos, calcados, segundo ele, na tradição clássica aristotélica, em que se valora apenas a dimensão estética das obras e se rechaça o engajamento literário. Além disso, filiava-se ao new criticism, movimento fundado nos anos 30 do século passado, na Inglaterra, que foi dominante na academia no Sul estadunidense - economicamente atrasado e com hábitos tradicionais - a partir da década de 50 do século XX e que defendia o close reading, ou seja, uma leitura intrínseca da literatura que desconsiderava o extrínseco, ou seja, o contexto de produção.

Hoje o crítico da UFRJ não é mais um nome tão presente na bibliografia dos cursos de Letras, ainda que a obra da qual é organizador seja uma das mais vastas na historiografia literária brasileira, abrangendo seis volumes publicados entre os anos de 1955 e 1959, e que integre os mais diversos estudiosos, desde um Luís Câmara Cascudo a um Antonio Candido. Entretanto, é importante destacar que a concepção teórica defendida por Afrânio Coutinho encontra muitas ressonâncias em parte da atual produção crítica de literatura, especialmente na que advoga valores universalistas, tais como os críticos Alfredo Bosi e Leyla Perrone-Moisés.

Um dos possíveis motivos do atual descrédito de Coutinho talvez seja seu posicionamento elitista em relação ao fenômeno literário, visto que, conforme afirma Luis Alberto Alves (2013, p. 229), “com a democratização recente da sociedade brasileira, não há como endossar impunemente uma visão elitista das elites, como sustentou Afrânio", além do que, como ressalta Eneida Maria de Souza (2002, p. 20), "a elitização cultural não mais se sustenta diante do apelo democrático dos discursos". Conforme saliente Ginzburg (2008, p. 102),

A posição de Afrânio Coutinho, afinal, não corresponde ao interesse de toda a humanidade. Ela serve para reforçar as condições de desigualdade e exclusão e silenciar as vozes de segmentos sociais que historicamente não tiveram direito à manifestação no campo das letras. 
Além disso, há uma ligação de suas concepções com uma ideologia conservadora, ao postular uma análise literária apolítica, que desvincula valores estéticos de situação social e contribui para um espaço de "inércia política, e portanto, de submissão ao status quo político" (Eagleton, 2006, p. 76).

Outro fator é a tomada de um aparato crítico retrógado em termos de teoria literária: "o grande mestre da crítica literária científica é Aristóteles, que deixou na Poética as normas para o assunto" (Coutinho, 1953, p. XI). Esse passo para trás na teoria também não deixa de ser um passo para trás quanto ao posicionamento político, visto que nada mais coerente para uma elite conservadora do que eleger Aristóteles como o arauto da teoria literária, despolitizando todo o debate literário; o que foi feito, ainda, por meio do estabelecimento de uma crítica literária objetiva e científica, portanto, acadêmica, sob o paradigma eleito por Afrânio. Essa tomada de posição derivou do incômodo desse crítico diante do que ele denomina de "culto da improvisação" (Coutinho, 1986, vol. 1, p.38), designado como "causa e efeito da falta de consciência técnica", "incultura", "descuido" da crítica literária brasileira.

Essa opinião no que se refere ao estatuto da crítica literária brasileira de seu tempo procede de seu intuito de legitimar o ofício do crítico literário e de afirmar a especificidade e primazia incondicionais do estético, conforme suas ideias. Para ele, é necessário o estabelecimento da autonomia da literatura, da crítica e do método de estudo empregado pela crítica em relação às outras ciências. Segundo Coutinho, a literatura tem

\begin{abstract}
um valor em si, e um objetivo, que não seria de comunicar ou servir de instrumento a outros valores - políticos, religiosos, morais, filosóficos. Dotada de uma composição específica, que elementos intrínsecos lhe fornecem, possui um desenvolvimento autônomo. A crítica é, sobretudo, a análise desses componentes intrínsecos, dessa substância estética, a ser estudada como arte e não como documento social ou cultural, com um mínimo de referência ao ambiente sócio-histórico (Coutinho, 1986, vol. 1, p. 46).
\end{abstract}

A abordagem metodológica que possibilitaria a realização desse tipo de crítica seria a "periodologia estilística", que libertaria "a história da literatura: 1) da tirania cronológica [...], 2) da tirania sociológica [...] e da tirania política" (Coutinho, vol. 1, p. 24). A referida periodização estilística é a divisão que Coutinho propõe em sua obra de história literária, a saber: Barroco, Neoclassicismo, Arcadismo, Romantismo, Realismo, Naturalismo, Parnasianismo, Impressionismo e 
Modernismo. Essa fórmula não foi, contudo, por ele demonstrada, uma vez que "jamais deixou provas materiais (da superioridade) do seu método, limitando-se quando muito a enquadrar obras no cânone em relação ao qual ele funcionava como uma espécie de jurista" (Alves, 2013, p. 224). Além disso, observa-se uma cegueira do crítico ao não considerar a possibilidade de a estilística, tal qual ele defende, também ser uma tirania teórico-metodológica.

Deve-se pensar essa concepção de literatura e historiografia literária em um contexto de busca de autonomia e profissionalização do campo das Letras em relação aos outros campos do conhecimento. Ela expressa a ideia de que a literatura deve deter-se ao estudo da Literatura, fenômeno independente de variações sociais, políticas, étnicas, linguísticas, econômicas; além de que as diversas manifestações do literário podem ser compreendidas por um único discurso sobre o literário, estabelecido com base em parâmetros, métodos e valores verificáveis, uma vez que vigia um contexto em que as ciências exatas eram o parâmetro de validação.

Isso foi buscado por Coutinho inclusive em relação à abordagem de estudo diacrônico da literatura, no qual ele rechaça a ideia de literatura colonial - por essa designação cunhar a literatura do Brasil como dependente da literatura da colônia - e formula, juntamente com outros críticos, a ideia de uma literatura barroca e brasileira (Coutinho, 1986, vol. 1, p. 107), ou seja, que dialoga com a estética barroca do mundo europeu, como todas as outras literaturas, e não apenas com as influências da colônia. Nesse sentido, a concepção de Coutinho apresenta-se abrangente, haja vista que possibilitaria, por exemplo, a abertura de nossa literatura a um mundo anterior ao da escrita, ao da oralidade, ao do trovadorismo como momento de criação poética da oralidade. Contudo, essa visão é estabelecida apenas em relação à consideração do Barroco como pedra inicial de nossa formação literária, continuando o crítico restrito a uma concepção escriptocêntrica da literatura brasileira.

Diferentemente de Coutinho, que elabora um conceito de literatura brasileira em diálogo com as estéticas artísticas e literárias em sentido amplo e não o restringe às influências da colonização (Portugal), Antonio Candido ([1950] 2000) ressalta a ligação da literatura brasileira com a portuguesa (ramo) e mesmo afirma a preponderância esmagadora da influência portuguesa (europeia) sobre a literatura brasileira. 
Esse ideário, segundo o qual nossas produções devem ser avaliadas com base em uma ideia de evolução da consciência literária pelos autores brasileiros e da acumulação progressiva capaz de ligar nossa literatura à portuguesa, construiu o paradigma da defasagem, da dissonância e do descompasso das "manifestações literárias brasileiras" em relação à literatura.

Além disso, também formulou a ideia de que, em literatura, há um contínuo do atrasado ao desenvolvido, de acordo com o qual a tradição da literatura deve ir em direção ao considerado desenvolvido e afastar-se, sem olhar para trás, do atrasado. Nesse sentido, Luís Augusto Fischer (2013, p. 195) afirma que "Candido cultiva uma perspectiva urbanocêntrica, a partir do modernismo paulista, e por isso pensa as obras ligadas a temas urbanos como pertencendo a um mundo mais desenvolvido, que se rege pelas leis gerais da literatura sem adjetivo pátrio".

A formulação e adoção dessa perspectiva contribuíram para o apagamento de autores e autoras desconectados dessa tradição, assim como para a desconsideração de um modo particular - uma tradição - de se construir textos, tal como a literatura de bases rurais e orais, por exemplo; embora Candido, em um momento particular, declare que literatura seja um conceito amplo.

Chamarei de literatura, da maneira mais ampla possível, todas as criações de toque poético, ficcional ou dramático em todos os níveis de uma sociedade, em todos os tipos de cultura, desde o que chamamos folclore, lenda, chiste, até as formas mais complexas e difíceis da produção escrita das grandes civilizações (Candido, [1988] 2004, p. 174).

O conceito de literatura proposto acima não encontra ressonâncias na atividade do crítico, que se detém na análise de "formas mais complexas e difíceis da produção escrita". Entretanto, são muitos os estudiosos de literatura que veem um avanço na tomada teórica de Antonio Candido. Jaime Ginzburg, por exemplo, ao pensar sobre a teoria literária presente nos cursos de Letras brasileiros, destaca a obra de Candido, que se apresenta como fundamental "na constituição de valores humanistas e no fomento aos direitos humanos" (Ginzburg, 2002, p. 65), sendo, segundo esse crítico, um avanço ${ }^{17}$ em relação às visões intrínsecas da literatura, representadas por Afrânio Coutinho e Hênio Tavares.

${ }^{17} \mathrm{O}$ estudioso Jaime Ginzburg aponta, entre as ideias que julga ser mais importantes para os estudos literários brasileiros contemporâneos, a obra de Antonio Candido como a responsável por trazer "valores humanistas" e a de Rita Terezinha Schmidt como a que ressalta a "função do profissional de 
A obra-mestra de Candido, Formação da literatura brasileira: momentos decisivos (1750-1880), publicada em 1950, é um dos estudos que trouxeram essa concepção mais humanista à nossa tradição de crítica literária. Formação enquadrase em uma conjuntura de valorização do nacional que pode ser observada pelas obras de Caio Prado Júnior, Evolução política do Brasil (1933) e Formação do Brasil contemporâneo (1942); Nelson Werneck Sodré, Formação da sociedade brasileira (1944); Raymundo Faoro, Os donos do poder: formação do patronato político brasileiro (1958); e Celso Furtado, Formação econômica do Brasil (1959). A esses estudos somam-se os de Gilberto Freyre, Casa grande \& senzala (1933), Paulo Prado, Retrato do Brasil: ensaio sobre a tristeza brasileira (1928), Sérgio Buarque de Holanda, Raízes do Brasil (1936). Do conjunto dessas obras, Raízes do Brasil é a que "não somente reproduz aquilo que era aparentemente 'difuso' nos anos vinte/trinta, mas gera, cria, e, também, inaugura toda uma tradição de uma determinada visão de nação, que tem sido propalada e difundida, até os dias de hoje" (Weber, 2009, p. 23).

No âmbito dessas publicações está Formação de Candido, que não consiste exatamente em obra de historiografia literária, uma vez que compreende apenas parte da história, Arcadismo e Romantismo, sob o argumento de que se trata dos "momentos decisivos" da literatura brasileira. Todavia, a articulação entre período literário, estrutura social e espaço tempo político e econômico caracteriza essa obra como historiográfica.

Aqui, nesta tese, Formação não é considerada meramente obra de crítica e historiografia literária a ser seguida no que se refere a seus pressupostos metodológicos e teóricos, mas um documento a partir do qual se pode acessar determinada concepção de literatura que se tornou hegemônica no Brasil. A defesa da ideia de nação no contexto literário deu-se como prosseguimento de um pensamento crítico reinante, o qual foi formulado, no âmbito das letras, no seio da Revista Clima $^{18}$, da qual Candido é um dos colaboradores de maior evidência. A

letras nas mudanças sociais". O autor não evidencia o papel da crítica literária feminista como propositora de uma "epistemologia reumanizada" (Schmidt, 1994, p. 31) e mesmo de uma nova epistemologia, citando essa importante teórica feminista de modo descontextualizado de seus pressupostos teóricos.

18 A Revista Clima consistiu em um periódico, lançado em 1941 e encerrado em 1944, em São Paulo, cujos integrantes, além de seu formulador Alfredo Mesquita, são: Antonio Candido, Gilda de Mello e Souza, Paulo Emílio Salles Gomes, Décio de Almeida Prado, entre outros. Com tom conservador e 
centralidade do discurso de formação da nação fixará a ligação da literatura com a vida nacional.

\begin{abstract}
A literatura do Brasil, como a dos outros países latino-americanos, é marcada por este compromisso com a vida nacional no seu conjunto, circunstância que inexiste nas literaturas dos países da velha cultura. Nelas, os vínculos neste sentido são os que prendem necessariamente as produções do espírito ao conjunto das produções culturais; mas não a consciência, ou a intenção, de estar fazendo um pouco da nação ao fazer literatura. (Candido, [1950] 2000, p. 18)
\end{abstract}

O compromisso com a vida nacional não é, como afirmado, algo tácito, mas construído ao longo de nossa história literária. Já em 1873, em seu conhecido texto "Notícia da atual literatura brasileira: instinto de nacionalidade" (1959), Machado de Assis propõe a existência de "certo sentimento íntimo" que torne o autor de literatura "um homem de seu tempo e de seu país, ainda quando se trate de assuntos remotos no tempo e no espaço" e, assim como Candido, propõe uma literatura sobre um país, como se o Brasil fosse um território coeso e homogêneo, sem diferentes classes sociais, etnias, gêneros, culturas.

Essa busca por uma única ideia de país e por uma literatura que reflita essa ideia de país, coerente, é levada a cabo por Candido, que constrói Formação com base nesse paradigma, afirmando que esse livro "não é uma justaposição de ensaios, mas uma tentativa de correlacionar as partes em função de pressupostos e hipóteses, desenvolvidos com vistas à coerência de um todo" (Candido, [1950] 2000, p.19). Mais ainda, para o crítico

\begin{abstract}
o eixo do trabalho interpretativo é descobrir a coerência das produções literárias, seja a interna, das obras, seja a externa, de uma fase, corrente ou grupo. Por coerência, entende-se aqui a integração orgânica dos diferentes elementos e fatores (meio, vida, ideias, temas, imagens, etc.), formando uma diretriz, um tom, um conjunto (...). A coerência é em parte descoberta pelos processos analíticos, mas em parte inventada pelo crítico, ao lograr, com base na intuição e na investigação, um traçado explicativo (Candido, [1950] 2000, p. 37).
\end{abstract}

A coerência, como objetivo e como fim, reflete o posicionamento da crítica literária hegemônica, e não necessariamente daqueles que escreviam, por diferentes razões e em distintas circunstâncias, os quais foram, em razão de sua incoerência com a noção de literatura estabelecida, excluídos da história dessa literatura. A busca

eminentemente universitário - de mentalidade uspiana, logo, francesa -, esse periódico tinha por apoiador nada menos que Mário de Andrade. 
pela coerência nesse âmbito pode ter apagado (ou pode-se dizer que apagou?) o diferente, o singular, o dissonante, os outros.

A despeito de Candido reconhecer a parcialidade da interpretação e da crítica literária, bem como a invenção da coerência pelo crítico, persiste a adoção de um critério exclusivista, baseado em um recorte epistemológico de teorias e práticas literárias de um grupo hegemônico e dominante que, com base em uma perspectiva histórica nacional da literatura, procura definir ao mesmo tempo o valor e a função das obras nesse contexto.

Ao empregar como método crítico uma abordagem teórica que considera tanto o valor estético como a função social da obra literária (texto e contexto), Candido adota uma linha do meio em relação às tendências gerais da crítica literária, desenvolvendo o método de "redução estrutural", ou seja, o processo de interiorização e transformação das condições sociais em estrutura literária. Outro conceito-chave da obra desse crítico, e talvez o mais importante, é o de sistema literário ${ }^{19}$, que se configura quando há a

\footnotetext{
articulação dos elementos que constituem a atividade literária regular: autores formando um conjunto virtual, e veículos que permitem o seu relacionamento, definindo uma 'vida literária': públicos, restritos ou amplos, capazes de ler ou ouvir as obras, permitindo com isso que elas circulem e atuem; tradição, que é o reconhecimento de obras e autores precedentes, funcionando como exemplo ou justificativa daquilo que se quer fazer, mesmo que seja para rejeitar (Candido, 1997, p. 13).
}

Conforme as ideias de Candido, anteriormente à configuração desse sistema literário havia no Brasil apenas "manifestações literárias", produções literárias feitas de forma dilatada, esparsa e isolada, sem continuidade e repercussão e sem constituir uma tradição, sendo a conformação do sistema literário o fator responsável por construir uma literatura "como fenômeno de civilização" (Candido, [1950] 2000, p. 24). O prosseguimento de "padrões universais" e a articulação com a "civilização" são os valores considerados responsáveis pelo nivelamento da literatura brasileira com a europeia e pela configuração de nosso sistema literário.

O Arcadismo é alçado como o primeiro momento literário em que há propriamente literatura brasileira, haja vista que nele se ajustou o sistema literário. $\mathrm{O}$

\footnotetext{
${ }^{19}$ A esse respeito ver Candido 1967, 1997 e 2000.
} 
Arcadismo, e não o Barroco $^{20}$, é tomado como ponto de partida para a pesquisa de Candido

porque plantou de vez a literatura do Ocidente no Brasil, graças aos padrões universais por que se regia, e que permitiram articular a nossa atividade literária com o sistema expressivo da civilização a que pertencemos, e dentro da qual fomos definindo lentamente a nossa originalidade. Note-se que os árcades contribuíram ativamente para essa definição, ao contrário do que se costuma dizer. Fizeram, com a seriedade dos artistas conscientes, uma poesia civilizada, inteligível aos homens de cultura, que eram então os destinatários das obras. Com isto, permitiram que a literatura funcionasse no Brasil (Candido, [1950] 2000, p.17).

O Arcadismo é um momento decisivo para a formação da literatura brasileira, em consonância com as ideias de Candido, porque consiste na primeira ocasião em que um grupo de intelectuais decide deliberadamente criar uma literatura brasileira, diferente das outras feitas no mundo, sendo esse o período em que se surge a literatura brasileira. O pontapé inicial da literatura no Brasil é definido pelo crítico como a existência de "preocupações eruditas e pelo desejo de difundir o saber" (Candido, [1950] 2000, p. 75). Essa concepção valoriza a criação de uma historiografia das regularidades, de um sistema literário que se constrói concomitante à criação de uma "vida intelectual", da "especificidade virtual do escritor", da "identificação do letrado como letrado", da "definição do status e do papel do escritor" (Candido, [1950] 2000, p. 74).

O conceito de literatura e o de sistema literário são atrelados unicamente a textos eruditos e hegemônicos do mundo das letras, desconsiderando-se as expressões literárias e artísticas presentes então no Brasil, mas que não se inseriam nesse painel de "literaturas empenhadas". Esse posicionamento foi estabelecido de vez em nosso pensamento crítico com a hegemonização do pensamento paulista/modernista (Fisher, 2013, p. 186) e a institucionalização das letras, bem como com a consequente exclusão de outras histórias, pontos de vistas e formas de expressão.

\footnotetext{
${ }^{20}$ Acerca da exclusão do Barroco da história literária hegemônica, ver a obra de Haroldo Campos $O$ sequestro do barroco na formação da literatura brasileira: o caso Gregório de Matos. Além da dissonância entre Candido e Haroldo de Campos no que se refere ao Barroco, houve discordância em relação à contraposição de suas esferas de pensamento. Ao passo que Candido participou da Revista Clima, conforme já citado, Haroldo envolveu-se com a revista Noigandres, lançada em 1952 e encerrada em 1959, sob forma de suplemento do Jornal do Brasil (Motta, 2002, p. 47), que se configurava como uma corrente formalista contrária á ideia de projeto nacional.
} 
Fundamentando-se e dando prosseguimento ao ideário do Romantismo e do Modernismo tanto como produção literária quanto como produção de crítica literária, Candido, conforme defende Abel Barros Baptista (2005), chancelou a ligação que a literatura brasileira fadou-se a ter com o projeto de nação, o que foi feito mediante a exclusão de diversos autores e obras que fugiam à tentativa do autor de integrar, de forma conciliatória, a cor local ao universal eurocêntrico, estabelecendo-se uma hegemonia de pensamento (Fisher, 2013) e um pensamento homogeneizador (Baptista, 2005), o que derruba e inviabiliza posturas dissonantes. O mesmo foi feito, de alguma forma, pelos críticos literários Sílvio Romero, José Veríssimo e Afrânio Coutinho.

\section{Alicerces: pressupostos de dominação colonial}

Segundo Candido, a literatura chega ao Brasil como uma imposição, como uma das ações dos colonizadores para garantir o domínio político, cultural e econômico sobre nossa terra. O crítico Alfredo Bosi (1992, p. 15) defende que "a colonização é um projeto totalizante (...): ocupar um novo chão, explorar os seus bens, submeter os seus naturais", havendo nos países formados mediante esse processo marcas e memórias das ações de ocupação, exploração e submissão. As memórias da colonização presentes no modo de se estudar as literaturas produzidas no Brasil e a permanência desse discurso produziram um pensamento crítico que, de alguma forma, contribuiu para reforçar estruturas de pensamento instauradas com a ideologia da colonização (portuguesa, europeia).

\footnotetext{
A colonialidade do poder e a dependência histórico-estrutural implicavam ambas a hegemonia do eurocentrismo como perspectiva epistemológica. No contexto da colonialidade do poder, a população dominada, nas novas identidades que lhes haviam sido atribuídas, foram também submetidas à hegemonia eurocêntrica como maneira de conhecer (Quijano, 1997 apud Mignolo, 2003).
}

Mesmo dizendo, em Formação, que a literatura no Brasil se formou com a superação da condição colonial, mediante a configuração de nosso próprio sistema literário, o ideário que fundamenta sua obra aceita a dependência colonial, pois, como afirma Quijano (1992, p. 12), "não obstante o colonialismo político tenha sido eliminado, a relação entre a cultura europeia, chamada também 'ocidental' e as outras, continua sendo uma relação de dominação colonial". 
Segundo Antonio Candido, a coexistência de obras, produtores literários, públicos e tradição (Candido, [1950] 2000. p. 23) marca a instauração de uma literatura brasileira "como fenômeno de civilização" (Candido, [1950] 2000, p. 24). Ao trazer a ideia de civilização para a conceituação de literatura, o autor evidencia os parâmetros críticos de que se utiliza para estudar a literatura brasileira, ou seja, aqueles traçados como universais pela colonização, os que seriam superiores aos demais. A ideologia colonial é reforçada no entendimento que se dá à literatura. A subalternização do não hegemônico atesta a colonialidade do poder ${ }^{21}$.

É defendida a autonomia e a diferenciação da literatura em relação à metrópole, mas, ao mesmo tempo, são defendidos os pressupostos da metrópole sobre o que se entende por literatura. A autonomia é relativa, haja vista que os pressupostos críticos da metrópole são continuamente reafirmados pelo discurso crítico.

Munido da mesma crença de Candido acerca do potencial de a literatura superar a condição colonial, Afrânio Coutinho afirma que "a literatura foi o maior instrumento dessa descolonização e modernização, que corresponde ao processo civilizatório" (1986, vol. 1, p. 156-7). Os críticos praticamente repetem-se em seus argumentos, que, se são válidos em relação à afirmação do Brasil como tal diante dos projetos da metrópole, não são pertinentes no que se refere à descolonização dos valores e paradigmas plantados pelo colonizador.

O colonialismo, principalmente o de exploração, condição do Brasil após sua tomada pelos portugueses, é perpetuado como estrutura de pensamento. Importantes autores debruçaram-se sobre o estabelecimento e a fixação dessas estruturas em diferentes territórios: Aníbal Quijano (1992 e 2005), no que se refere à diferença colonial e colonialidade do poder; Michael Hardt e Antonio Negri (2001), em referência ao império; Ella Shohat e Robert Stam (2006), em relação ao eurocentrismo; Edward Said (2007), acerca do orientalismo; Homi Bhabha (2012), sobre diversidade cultural e diferença cultural.

\footnotetext{
${ }^{21} \mathrm{O}$ conceito de "colonialidade do poder" foi desenvolvido por Aníbal Quijano, ao longo da década de 90 do século passado, quando nas ciências sociais se questionava a pretensa universalidade de paradigmas eurocêntricos e se propunha a validade de outros, subalternizados pela dominação colonial e o colonialismo (Quijano, 1992).
} 
A perspectiva desses autores, ao estudarem casos específicos de dominação cultural, leva à conclusão de que as diferenças de valoração de tradições culturais manifestam a própria "diferença colonial” - Quijano ([1971]2014 e Mignolo (2003) bem como os processos de distinção cultural (Bourdieu, 2007), subalternização (Spivak, 2003) e marginalização (Saraiva, 1996); ao contrário do que defendem os teóricos favoráveis à ideia de cânone, tais como Harold Bloom (1995), segundo os quais as diferenças de valoração de tradições culturais manifestam uma estrutura hierárquica presente em todas as tradições culturais.

Os estudos literários brasileiros ainda estão arraigados de ideais colonialistas, assim como as outras áreas das humanidades, o que ocorre muito em razão da fixação de determinado pensamento sobre o Brasil por certo grupo de intelectuais $^{22}$. No âmbito da crítica literária, Antonio Candido foi quem com pungência defendeu a tese de formação de uma literatura brasileira "ramo da portuguesa" (Candido, [1950] 2000, p. 28). Aqui não se está rechaçando a importância da colonização portuguesa no desenvolvimento do que se denomina literatura brasileira - até porque não se poderia, uma vez que o cânone é a prova da ampla participação dos ideais da colonização na formação do pensamento crítico e intelectual brasileiro -, mas se está ressaltando a subserviência a esses ideais e o que essa atitude implica: exclusão, deslegitimação de outras formas de se produzir literatura e crítica literária. A ideia de uma literatura inquestionavelmente colonizada é naturalizada, não se interrogando, por exemplo, a respeito das exclusões.

\begin{abstract}
Com efeito, no momento da descoberta e durante o processo de conquista e colonização, houve o transplante de línguas e literaturas já maduras para um meio físico diferente, povoado por povos de outras raças, caracterizados por modelos culturais completamente diferentes, incompatíveis com as formas de expressão do colonizador. No caso do Brasil, os povos autóctones eram primitivos vivendo em culturas rudimentares. Havia, portanto, afastamento máximo entre a cultura do conquistador e a do conquistado, que por isso sofreu um processo brutal de imposição (Candido, 1997, p. 9-10).
\end{abstract}

Embora Candido ateste a existência de modelos culturais diferentes e afirme que o modelo do autóctone não teve participação na construção da literatura erudita e culta, não se pode negar que aquela cultura integrou a vida dos brasileiros desde

22 Os mesmos autores que participaram, conforme dito anteriormente, da construção de um pensamento de formação da nação brasileira, a saber: Caio Prado Júnior, Nelson Werneck Sodré, Raymundo Faoro, Celso Furtado, Gilberto Freyre, Fernando Novais, Paulo Prado, Sérgio Buarque de Holanda. 
então, principalmente dos brasileiros que não detinham a cultura erudita, escrita, em virtude do desconhecimento da língua portuguesa ou, posteriormente, do analfabetismo. A brutal imposição ressaltada pelo crítico diz respeito ao mundo da escrita e não ao mundo da oralidade, que teve influência, sim, desses outros modelos culturais.

A hegemonia de uma cultura e tradição escriptocêntrica foi, contudo, responsável por contar-se unicamente a história dessa cultura e tradição e por serem desprezadas outras histórias. Mais uma vez o estudo de Antonio Candido é revelador desse pensamento parcial.

\begin{abstract}
A sociedade colonial brasileira não foi, portanto (como teria preferido que fosse certa imaginação romântica nacionalista), um prolongamento das culturas locais, mais ou menos destruídas. Foi transposição das leis, dos costumes, do equipamento espiritual das metrópoles. A partir dessa diferença de ritmos de vida e de modalidades culturais formou-se a sociedade brasileira, que viveu desde cedo a difícil situação de contato entre formas primitivas e formas avançadas, vida rude e vida requintada. Assim, a literatura não 'nasceu' aqui: veio pronta de fora para transformar-se à medida que se formava uma sociedade nova (Candido, 1997, p.10).
\end{abstract}

A concepção esboçada a respeito do contato entre culturas eruditas e populares no período colonial foi tomada como um discurso totalizante da arte produzida em solo brasileiro. Todavia, enquanto uma parte da cultura da sociedade colonial brasileira consistia em prolongamento da metrópole, outra consistia na mistura do que vinha da metrópole e do que aqui já havia. Transitando entre espaços seus e alheios, muito em decorrência do trabalho que faziam, escravos e indígenas, por exemplo, viviam outras realidades culturais. A literatura desses atravessadores de casas sob um céu aberto nasceu aqui e foi, em alguma parte, influenciadora desta e influenciada por esta literatura "pronta" da metrópole. O próprio Candido ressalta, em outro momento, que

\footnotetext{
parece possível afirmar que a literatura brasileira, embora esteja embasada em padrões cultos fortemente impostos, e embora tenha contribuído para definir o sistema de dominação política e social, possua correntes reprimidas, oriundas, seja de padrões mais populares, seja de modelos heterodoxos (Candido, 1981, p. 81).
}

Ainda que declare a existência dessas correntes literárias, sobre elas não se debruça, e nem ao menos lhes atribui importância - até mesmo por questões de 
conjuntura histórica -, visto que, para ele, o "problema" dessas outras literaturas se vincula

\begin{abstract}
ao remorso que temos de participar de uma literatura culta, sem querer renunciar às outras. Nós lemos Mallarmé, Proust, Joyce, Kafka, mas afirmamos ao mesmo tempo que a literatura autêntica poderia ser outra a do índio, a do negro, a afroamericana, a popular. É uma velha tradição de mauvaise conscience, que inclusive, no Brasil, levava as pessoas a afligirem-se por terem nomes portugueses e mudá-los por nomes indígenas, como se esse ritual nativista mudasse a essência das coisas. Seja como for, isto levanta o seguinte problema, que devemos considerar no projeto: temos de dar algum tratamento as "outras" literaturas, não só para a dominante - o que é difícil e varia de importância de acordo com os países (Candido, 1981, p. 80).
\end{abstract}

A questão é que não se trata unicamente de "remorso", mas de uma dívida real no que diz respeito a essas literaturas apagadas em um período de exploração colonial. Mais do que má consciência e débito com nossas literaturas, trata-se de um débito com nossas histórias e da superação da concepção de que possuímos apenas uma tradição literária, a erudita. Conforme afirma Alfredo Bosi, no Brasil - Colônia,

a criação popular dispôs de condições para produzir-se: a) ou em espaços ilhados vistos hoje, retrospectivamente, como arcaizantes ou rústicos; b) ou na fronteira com certos códigos eruditos ou semi-eruditos da arte europeia: na música, nas festas e na imaginária sacra, por exemplo. O romance de cordel, caso de criação de fronteira, é tardio, o que se explica pelos entraves à alfabetização e à impressão em todo o período colonial (Bosi, 1992, p. 25).

Os entraves à impressão apontados por Bosi referem-se à atitude de aversão da Coroa portuguesa à disseminação da tipografia, que a fez proibir a instalação da imprensa no Brasil, o que, de alguma forma, contribuiu para o prolongamento de um mundo unicamente oral. Afrânio Coutinho (1986, vol. 1, p. 54) também dá notícia da existência de trovas populares no Brasil-Colônia:

cantadas pelos primitivos trovadores das cidades e dos sertões, quando os homens simples, que começavam a aglomerar-se na Colônia, procuravam expandir suas alegrias ou manifestar as suas tristezas e temores diante dos fatos novos, às vezes hostis, que a natureza lhes punha diante, sugestionando-lhes a imaginação.

Ainda que seja reforçado o preconceito de que se tratava de "primitivos trovadores" e "homens simples", é atestada a existência desses artistas nesse período no Brasil, embora haja um silêncio na historiografia em relação à obra desses artistas, que os exclui como formadores de nossa literatura, que os tem como "matéria- 
prima". Afrânio Coutinho inclusive ressalta a participação desses como iniciadores de nossa literatura:

\begin{abstract}
A literatura brasileira teve início imediato quando o homem novo começou a construir suas imagens em termos da nova realidade, pela voz de seus cantores populares, através das inúmeras formas folclóricas, e, em fase mais avançada, pelos seus poetas, pregadores e oradores (...) sob forma artística, [a literatura brasileira] já se encontra em Anchieta, Gregório de Matos, Antonio Vieira (Coutinho, 1986, vol. 1, p. 130).
\end{abstract}

Há o reconhecimento pelo autor de que a literatura brasileira não nasce pela escrita, discurso veiculado pela maior parte dos críticos literários que ignoram a oralidade como meio de composição literário. Contudo, distingue hierarquicamente, forma folclórica de forma artística, desprezando aquela como parte real da historiografia brasileira, o que pode ser reforçado pelo fato de, na obra de Coutinho destinada a cobrir nossa historiografia literária, apenas na parte denominada "Generalidades", haver um capítulo que trata de folclore, literatura oral e literatura popular, o qual ficou a cargo do folclorista Luís da Câmara Cascudo. Nesse capítulo, o autor trata do que chama de cultura popular ou não oficial, ou seja, uma cultura "tradicional, oral, anônima, independente de ensino sistemático porque é trazida nas vozes das mães, nos contos de caça e pesca, na fabricação de pequeninas armas, brinquedos assombros" (Cascudo, 1986, p. 184), que, também formada por obras impressas, não compõe a história literária brasileira, mas está nas mentes e mãos de seu povo. Essa postura reflete a atitude de negação do diferente e de fixação de uma tradição cultural e literária ligada às elites, o que se sucede em nossa literatura desde o período colonial brasileiro, em que, segundo Wilton Cardoso (1986, vol. 1, p. 172),

\footnotetext{
o monopólio do sistema educacional que os jesuítas construíram rápida e objetivamente logo os transforma, como diz Gilberto Freire, em agentes de destruição das culturas não europeias e os inscreve numa espécie de tecnocracia posta a serviço da expansão da classe dominante.
}

A literatura e o discurso crítico sobre ela participam do processo de expansão da classe dominante e de seus ideais e da formulação de um discurso sobre a inferioridade do que não é da elite, fundada em um território cercado de imensa desigualdade social e fortes mecanismos econômicos e sociais de criação e fixação de uma distinção econômica e cultural, sendo a escola um dos meios de reverberação desse processo. De acordo com Fernando de Azevedo (1986, vol. 1, p. 193), "no Brasil, o sistema educacional que se montou na colônia e constituiu a base sobre que se ergueu o do Império apresenta-se intimamente associado à família, à Igreja, ao poder econômico e político, num conjunto de instituições convergentes e solidárias”. 
O autor ainda argumenta que, embora a escola seja um espaço de reprodução, ela não é um espaço de criação e inovação de ideais, mas apenas de manutenção de uma tradição, no caso, a da elite.

\begin{abstract}
No setor das artes e da literatura, tem sido sempre, aqui como por toda parte, muito reduzida a ação da escola, em face de experiências ulteriores, múltiplas e imprevisíveis, que, sobrepondo-se aos rígidos quadros escolares e às culturas organizadas, criam estímulo e abrem os caminhos mais diversos às criações do espírito. Onde, pois, se devem buscar as origens, tantas vezes obscuras, do movimento e das produções literárias, é antes nas mudanças do 'meio interno', nos contatos de culturas diferentes, na circulação de livros e periódicos ('uma coleção de livros é a melhor universidade' dizia Carlyle), nos lazeres que abrem ensejo à formação de focos intelectuais, na menor ou maior intensidade de participação na comédia humana, nas solicitações da vida e de seus problemas e na força das vocações autênticas, que se realizam, com escolas ou a despeito delas, no silêncio fecundo das bibliotecas, na intimidade das reuniões provadas ou nos ásperos contatos com a realidade, em que se sucedem e se revezam obstáculos, desafios e incentivos. Toda essa fermentação espiritual e cultural que se processa, dentro de determinadas ambiências históricosociais, é que constitui, na base e ao calor dos dons naturais de cada um, o crisol em que se elaboram, na sombra ou no tumulto, as elites intelectuais (Azevedo, 1986, vol. 1, p. 207).
\end{abstract}

Fernando de Azevedo naturaliza o processo de construção de uma literatura - ao sugerir que da convivência em um campo cultural de elite advém as inovações literárias, os escritores dessa literatura e os seus leitores. O sociólogo Pierre Bourdieu, em As regras da arte: gênese e estrutura do campo literário (1996), trata dessa problemática ao formular o conceito de campo literário.

O produtor do valor da obra de arte não é o artista, mas o campo de produção enquanto universo de crença que produz o valor da obra de arte como fetiche ao produzir a crença no poder criador do artista. Sendo dado que a obra de arte só existe enquanto objeto simbólico dotado de valor se é conhecida e reconhecida, ou seja, socialmente instituída como obra de arte por espectadores dotados da disposição e da competência estéticas necessárias para a conhecer e reconhecer como tal, a ciência das obras tem por objeto não apenas a produção material da obra, mas também a produção do valor da obra ou, o que dá no mesmo, da crença no valor da obra (Bourdieu, 1996, p. 259).

O conceito de sistema literário desenvolvido por Antonio Candido também se aproxima do de campo literário estabelecido décadas mais tarde pelo sociólogo francês, embora se trate de um conceito específico, elaborado para o caso brasileiro, e o de Bourdieu sirva ao caso francês. Da forma como é descrito o sistema literário, esse se apresenta como um espaço de objetividade, universalidade e atemporalidade, em que as obras, se possuidoras de valor literário, são necessariamente incorporadas 
a esse sistema. Nesse sentido, o valor da obra seria inerente a ela, e o público (formado pelos bons leitores) seria meramente o reconhecedor de suas qualidades literárias intrínsecas, haja vista que a obra em si produz o seu valor literário, na medida em que dialoga com uma tradição de obras e autores anteriores e que é o gênio do autor que, consequentemente, produz a obra. $\mathrm{O}$ valor da obra seria, então, reconhecido pelo público ou, caso se trate de escritores incompreendidos ou desconhecidos em seu tempo, pela posteridade.

Ainda que reforce ser a natureza intrínseca da obra literária o essencial para a sua valorização artística, Antonio Candido reconhece o papel das instâncias extrínsecas nesse processo de atribuição de valor, incluindo em sua definição de sistema literário o leitor, mesmo que dê a ele apenas o papel de reconhecedor.

Esse reconhecimento, contudo, não se caracteriza por objetividade, universalidade e atemporalidade, e não advém mecanicamente da "produção material" da obra, ou seja, por sua mera existência no mundo, mas pela "produção de seu valor", que não é objetivo, nem universal, nem atemporal, nem isento de disputas por poder.

O fechamento do universo das letras a produções dissonantes que não respondem a seus paradigmas, tal como atestam os conceitos de sistema literário e campo literário, acirra ainda mais a hierarquia entre produções de dentro e de fora do campo literário. Mais uma vez Antonio Candido, em texto dedicado ao escritor e ao público de literatura brasileira, contrapõe "o esforço de criação artificial dum público por parte dos próprios escritores" (Candido, 1986, vol. 1, p. 222) à existência de "uma sociedade de iletrados, analfabetos ou pouco afeitos à leitura" (Candido, 1986, vol. 1, p. 224), que formava um "público de auditores" (Candido, 1986, vol. 1, p. 224) que requeria do escritor

certas características de facilidade e ênfase, certo ritmo oratório que passou a timbre de boa literatura e prejudicou, entre nós, a formação de um estilo realmente escrito para ser lido. A grande maioria dos nossos escritores, em prosa e verso, fala de pena em punho e prefigura um leitor que ouve o som da sua voz brotar a cada passo por entre as linhas (Candido, 1986, volume 1, p. 224)

Ao contrapor esses públicos, o crítico desprestigia a participação da oralidade da formação da literatura brasileira, encarando-a como um elemento que “prejudicou” esse processo, e revela sua concepção escriptocêntrica de literatura, 
segundo a qual o literário se pauta apenas no eminentemente escrito, impresso e lido. Os "públicos receptivos de auditores" são conceituados por Candido (1986, vol. 1, p. 226) como ilegítimos, visto que a literatura a que são capazes de apreciar ainda não é propriamente literatura.

A bonita descrição que Candido acaba fazendo de nossa literatura do período colonial - uma literatura escrita e ao mesmo tempo oral, uma literatura para a leitura e ao mesmo tempo para a escuta - ganha, mediante a argumentação traçada no texto, um tom de reprovação. $\mathrm{O}$ relato de um tempo em que se hibridizavam aspectos da oralidade e da escrita em nossa literatura é carregado de uma concepção escriptocêntrica que entende os traços da oralidade como algo a ser superado.

A estudiosa Ria Lemaire argumenta que essa concepção exprime e divulga "geralmente a ideologia das elites e da sua relação com o poder" (Lemaire, 2007, p. 9.), o que pode ser verificado no caso da literatura brasileira que, segundo o próprio Antonio Candido, recebia

\footnotetext{
o frequente amparo oficial de D. Pedro II, [d]o Instituto Histórico, em parte [d]as academias de direito (Olinda - Recife e São Paulo) - que de um lado acolhiam a atividade literária como função digna; de outro, podavam-lhe as demasias, pela padronização imposta ao comportamento do escritor na medida em que era funcionário, pensionado, agraciado, apoiado de qualquer modo (Candido, 1986, vol. 1, p. 225).
}

O quadro que Candido faz desse período não é bom, de um lado uma literatura para públicos receptivos de auditores e de outro para as instituições ligadas ao Estado. O crítico evidencia as amarras da literatura feita no Brasil colonial que a desqualificam e a impedem de tornar-se grande nesse período e mesmo em períodos posteriores, já que, segundo o crítico, "o afastamento entre escritor e massa veio da falta de públicos quantitativamente apreciáveis, não da qualidade pouco acessível das obras" (Candido, 1986, vol. 1, p. 227).

A proposição de que nossa literatura em seus inícios era deficientemente oral porque tinha um público com deficiente compreensão de uma escrita feita conforme padrões da escrita nos permite observar a subserviência de nossa crítica a valores literários construídos, ainda no Brasil-Colônia, com base no que Antonio Candido denomina de ideais de civilização, dos quais nossa literatura se afastava pelas questões acima citadas. A crítica feita pelo estudioso reproduz o ideal colonizante de substituição do que existe pelo que o colonizador acredita que deva 
existir. Um exemplo disso foi a imposição de um padrão de língua falada e, posteriormente, de escrita a partir dos modelos da metrópole (Castro, 1986, p. 273), o que influenciou na fixação de um padrão de escrita literária prestigiado.

Em um contexto de questionamento do valor das obras literárias brasileiras tornadas canônicas e de valorização dos cânones tidos como universais no ensino de literatura no Brasil, o controverso estudioso Flávio Kothe defende que

\begin{abstract}
o direito das minorias culturais existirem como tais não era reconhecido, sem considerar o fato de que uma cultura se torna tanto mais forte quanto mais subculturas abriga ativamente dentro de si. Isso não cabia no espírito da Reconquista, no dogmatismo da Contra-Reforma, na ambição "bandeirante", na mentalidade colonial da oligarquia autoritária, cujos traços marcaram a formação do país, levando sua elite mais à exclusão do que à inclusão das múltiplas culturas do país (Kothe, 1997, p. 184).
\end{abstract}

A afirmação e a legitimação da cultura de elite, bem como a autonomia dessa, ocorreram mediante a subjugação e deslegitimação das demais culturas, que são qualificadas como culturas menores. Essa questão pode ser observada no tratamento dado às obras que traziam, de alguma forma, elementos populares, como a oralidade, para a literatura. Isso se deve, em alguma medida, ao momento de autoafirmação da inteligência brasileira, que desprezou, com o intuito de autoafirmar-se, as influências da oralidade e do popular. Esse período se deu logo nos primeiros anos do século XIX, quando os intelectuais, com o apoio de D. João VI, fomentaram a criação de "imprensa, periódicos, escolas superiores, debate intelectual" (Candido, [1950] 2000, p. 215). A contribuição de D. João VI evidencia a ligação dos intelectuais com o estado, fenômeno que foi responsável em parte pela vinculação da literatura à construção de uma nação, de modo que os escritores que ganharam importância em nossa historiografia literária foram os que se atrelaram a esse projeto, e os dissonantes, em sua maioria, não integram esse rol ou nele entram como pecha.

Com a instauração dessa ideologia, a definição de literatura exclui a produção de livros populares, a despeito de a difusão de livros ainda ser ínfima. A literatura cunhada por Candido como "popularesca", "mais divulgada e estimada pelo leitor inculto" (Candido, [1950] 2000, p. 220), não compõe objeto de análise desse período de configuração de uma literatura brasileira, a não ser como exemplo do que não tem valor, tal como ocorre com a obra de Domingos Caldas Barbosa. 


\section{Domingos Caldas Barbosa}

Domingos Caldas Barbosa (1740-1800), que muitas vezes assinou como Lereno Selinuntino, foi um poeta brasileiro, filho do português Antonio Caldas Barbosa e da angolana Antonia de Jesus, provavelmente escrava de seu pai. Sua poética é marcada por sonoridade popular, improvisação. Foi compositor de modinhas e lundus, os quais ele cantava sempre com a companhia da viola, o que, segundo Eduardo de Assis Duarte (2014, p. 156), remete sua poética à cultura popular - temos uma viola em vez de lira, harpa ou flauta.

Obteve grande sucesso de público, afirmam diversos pesquisadores, devido às performances que promovia nos salões da nobreza portuguesa, o que lhe causou desentendimento com Bocage, ressentido pelo reconhecimento alheio e munido tanto de preconceito racial quanto de xenofobia, visto que se tratava de um brasileiro, negro, em terra lisboeta. O sucesso de Caldas Barbosa deve-se, em grande medida, à permeabilidade de sua obra a um público amplo, em decorrência de a publicação darse tanto em forma impressa quanto, e principalmente, em meio oral, com o canto de seus poemas, suas modinhas e lundus.

\section{Caldas Barbosa foi provavelmente o que gozou o maior êxito em vida. No entanto, nenhuma das Histórias da Literatura dos países ao qual pertenceu, por nascimento ou por atividade profissional, o menciona com destaque na mesma proporção do seu sucesso (Sawaya, 2011, p. 118).}

Observa-se um descompasso em relação à avaliação de sua obra; tem-se, ao mesmo tempo, reconhecimento de público e menosprezo da crítica, o que ocorre muito em decorrência à estética popular e oral adotada por vezes por Domingos Caldas Barbosa, que, no conjunto de sua obra, apresenta grande plasticidade e hibridismo, já que o tom popular e oral coexiste com referências eruditas. Ao percorrer as fronteiras do erudito e do popular, assim como as da literatura, da música e da cultura portuguesa e brasileira, sua obra não é caracterizada positivamente pela maior parte da crítica literária brasileira, e portuguesa, que erigiu nossa historiografia literária.

Nas principais historiografias literárias brasileiras em que consta sua obra, ela é caracterizada negativamente. Entre os estudiosos que se referem ao poeta incluem-se Sérgio Buarque de Holanda (1953), Teófilo Braga (1876 e 1984), Sílvio Romero (1882 e 1980), José Veríssimo (1969) e Francisco Adolpho Varnhagen (1850). 
Antonio Candido, em capítulo dedicado à análise da poesia e música em Silva Alvarenga e Domingos Caldas Barbosa, estuda a obra daquele poeta ao longo de doze páginas, ao passo que à de Caldas Barbosa reserva duas, o que se deve, conforme ressalta o crítico paulista, ao fato de Caldas ser "um simples modinheiro sem relevo criador", "pela inocuidade geral da sua lira" e pelo fato de "o "trovista Caldas', tão simpático e boa pessoa, tão maltratado por Bocage, desaparecer praticamente ao lado dos patrícios mais bem dotados" (Candido, [1950] 2000, 1423). Bem como Candido, José Osório de Oliveira (1964, p. 40-41) ressalta a pequenez de Caldas Barbosa em relação aos seus pares, classificados como "poetas secundários da plêiade mineira do século XVIII".

Para um crítico que atribui tanta importância ao Arcadismo, Candido tece apenas comentários a respeito de Caldas. De acordo com Adriana Campos Rennó (1999 e 2005), essa discrepância advém do fato de Caldas trazer um Arcadismo com acordes dissonantes. Nas palavras de Reinaldo Martiniano Marques (2011, p. 52),

\begin{abstract}
se, por um lado, seu estilo é marcado por uma linguagem clara, imagens de cunho mais lógico e um léxico mitológico-clássico, o que revela mais como epígono do Arcadismo, de outro, ressalta, sobretudo em sua Viola, uma sensibilidade nativa, formalizada em quadras marcadas por versos breves, especialmente as redondilhas, pela sensualidade, o tom amoroso e de súplica, em que se desponta uma lírica popular, com laivos de préromantismo.
\end{abstract}

Em História da literatura portuguesa, Antonio José Saraiva e Osório Lopes (1987, p. 672-678) também ressaltam o papel de Caldas como precursor do Romantismo.

Convém notar que Caldas Barbosa (1740 - 1800), o Lereno da Nova Arcádia, amolece e populariza certos temas arcádicos para os adaptar às modinhas brasileiras que o celebrizam. Certa cor local e certo dengue brasileiro constituem, no conjunto destes poetas [da Escola Mineira], uma contribuição importante para a formação do gosto romântico entre nós.

Antônio Soares Amora avalia a obra Viola de Lereno - composta de dois volumes cuja primeira edição é de 1798 e a segunda é de 1826, tendo tido diversas outras reedições, e que consistiu na compilação de cantigas cantadas em festas na corte - como um tipo de "poesia folclórica" (Amora, 1986, p. 220) e a classifica como um momento de transição do Arcadismo para o Pré-Romantismo. Waltensir Dutra, corroborando a opinião de Amora, classifica Caldas como um poeta de transição, que, como seus contemporâneos, 
intitulou-se pastor, falou em gado e choça, seguindo, sempre que podia, os modelos da Arcádia. Mas mesmo quando o continente era repetição, o conteúdo trazia inovações: o bucolismo era menos frequente, a linguagem mais espontânea, coloquial, jogando com elementos e situações urbanas. A sua posição social impunha-lhe ser, nas festas da corte lisboeta, onde viveu grande parte da sua vida, uma espécie de jogral; para distraí-la, cantava, acompanhando-se ao violão, lundus, modinhas (Dutra, 1986, p. 240).

Esse descompasso com as escolas literárias foi um dos grandes entraves à inserção positiva da obra de Caldas na historiografia literária brasileira e portuguesa. O "músico-poeta” Domingos Caldas Barbosa (Rennó, 2005, p. 115) não se encaixou na tradicional história e periodização literária, que, à época, não valorizava o hibridismo que se apresentava. Mesmo os críticos literários modernos não reconhecem essa característica como um valor. Alfredo Bosi, em sua obra historiográfica, caracteriza Caldas como "um caso típico de contaminatio da tradição oral, falada e cantada, com a linguagem erudita" (Bosi, 1994, p. 79) e, assim como Candido, atribui importância à obra de Silva Alvarenga em detrimento da de Caldas, tratada apenas em nota de rodapé.

O crítico mineiro, a despeito de ressaltar as inovações de conteúdo trazidas pelo escritor de Viola de Lereno, afirma que "o valor de Caldas Barbosa como poeta é exclusivamente histórico", não tendo esse atingido o nível literário de escritores como Silva Alvarenga.

As liberdades que tomava para enquadrar os versos em música, ou ao improvisar, afastaram-no do rigor arcádico, impedindo-lhe a adoção de um esquema métrico, rítmico, ou rimático.(...), faltou-lhe habilidade para disfarçar com jogos formais rebuscados, como fez muito bem Silva Alvarenga, os lugares-comuns da poesia arcádica (Candido, [1950] 2000, p.241).

As "liberdades" às quais Candido se refere nada mais são do que os recursos da oralidade empregados por Caldas - visto que se trata de um poeta-músico cuja obra se destina majoritariamente ao canto e não à leitura - considerados "menores" pelo crítico, que valoriza o rebuscamento como forma de disfarce para o nada dizer. Os recursos da oralidade são, contudo, os que propiciam a apreciação da obra desse poeta na atualidade, segundo Antonio José Saraiva e Osório Lopes (1987, p. 680).

O canto ajuda-o a desarticular a fraseologia erudita, a introduzir interjeições, bordões ou frases feitas da sua fala oral nativa. [...]. Com toda a sua superficialidade, em suma, Caldas Barbosa é dos raros setecentistas cujo texto mantém uma certa viveza oral ainda hoje. 
Os pesquisadores da atualidade que se propõem a reler a obra de Caldas Barbosa reiteram a ideia de pequenez de seu tom popular e oral e de grandiosidade de sua obra erudita, atribuindo o esquecimento de Caldas ao conhecimento limitado da crítica do passado à sua obra, uma vez que só se considera Viola de Lereno, desconsiderando-se Almanak das musas, que foi publicado em quatro volumes pela Academia de Belas Letras entre 1793 e 1794, sendo Caldas seu organizador e coordenador. Adriana Campos Rennó (1999 e 2005), Luiza Sawaya (2011) e José Ramos Tinhorão (2004) estão entre esses estudiosos que retomam o estudo de Caldas Barbosa por meio da análise de sua obra horaciana, ou seja, mais clássica e erudita, que se contrapõe estilisticamente à Viola de Lereno, em uma tentativa de inseri-lo em um cânone de escritores eruditos e no rol dos grandes escritores da historiografia literária.

\footnotetext{
Se ao contrário do que têm feito desde o século XIX historiadores e críticos literários, considerar-se que houve estilisticamente não um, mas dois Domingos Caldas Barbosa - um cultivador do neoclassicismo horaciano, outro fazedor-improvisador de versos para cantar -, a avaliação do poeta-compositor se tornaria mais fácil e mais justa (Tinhorão, 2004, p. 111).
}

Essa divisão da obra do poeta, havendo-se uma obra horaciana, representada pelo Almanak das musas, e outra popular, evidenciada por Viola de Lereno, é proposta, entre outros objetivos, para reinseri-lo na historiografia literária brasileira. Ao destacar a obra erudita de Caldas, esses pesquisadores fazem frente aos críticos literários que a desqualificam com base, quase que exclusivamente, na escrita caracterizada como popular do autor, desconsiderando-se sua obra erudita. Colocam em primeiro plano a obra erudita com o intuito de trazer os versos de Caldas que coadunam, de alguma maneira, com as estéticas arcádicas e pré-românticas, de modo que a duplicidade estilística da obra de Caldas Barbosa continua sendo em parte reprovada.

A despeito da enorme importância desses estudos, que trazem à tona a obra erudita de Caldas Barbosa, é preciso refletir sobre a presença de matrizes populares e orais na obra desse poeta. Caldas Barbosa é um poeta-improvisador e sua verve popular e oral é que o faz ir à busca de ritmo, musicalidade e rima em detrimento da palavra, diferenciando-o dos demais poetas de seu tempo e mesmo afastando-o da 
historiografia e cânone literários, que se fundamenta em um ideal de forma literária erudito.

No poema "Carta Primeira de Lereno a Arminda", Caldas Barbosa dá a sua pupila as orientações básicas para a criação de versos, segundo ele, “de arte menor". Logo no $21^{\circ}$ verso, de um total de 657 versos, diz-se no poema:

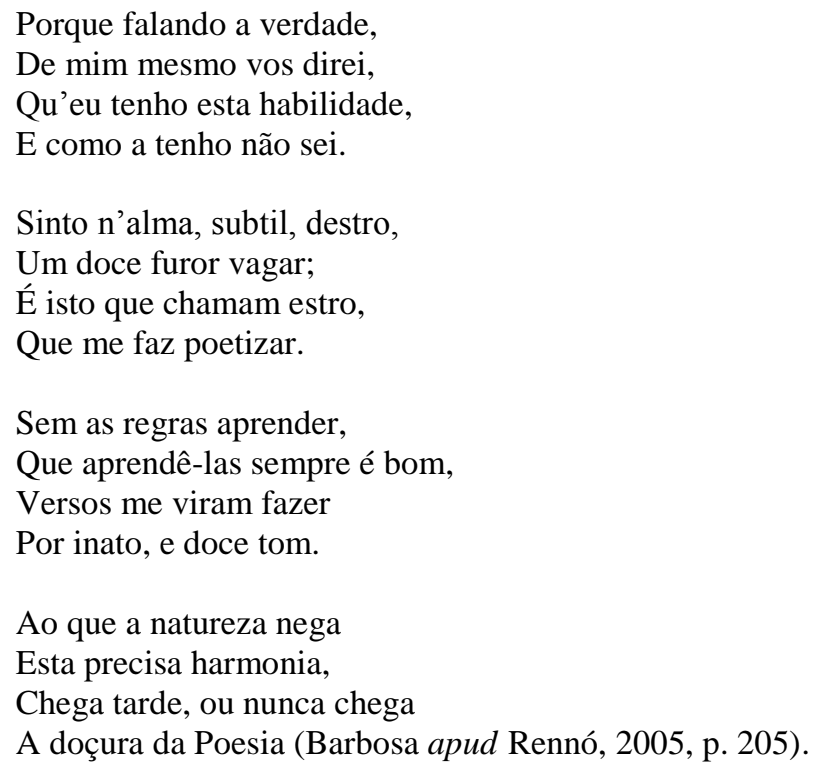

Ao atribuir sua habilidade poética à existência de um dom inato, o poeta reitera o discurso erudito e acadêmico segundo o qual as poéticas orais não são fruto de trabalho intelectual, mas apenas advêm da inspiração, sendo, por isso, uma arte menor. Quando trata da "arte maior", na "Carta segunda a Arminda", o poeta não emprega o mesmo discurso a respeito da criação poética, traçando regras atribuídas à composição erudita. Porém, é importante ressaltar que nesta obra o poeta relativiza as regras de composição árcade.

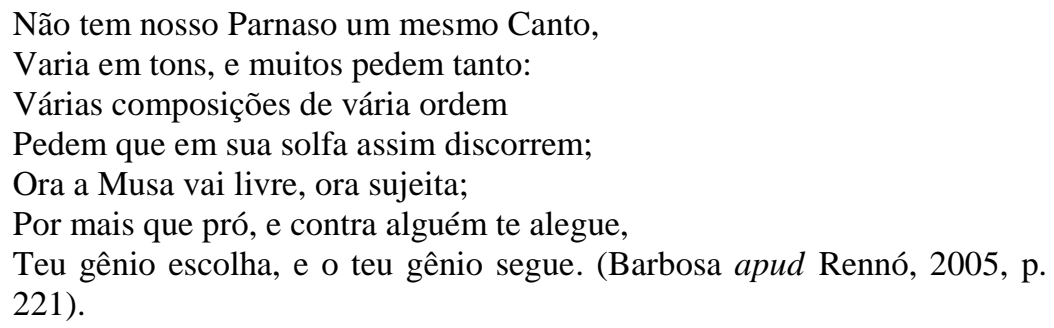

A relatividade das considerações feitas por Caldas Barbosa evidencia sua postura diante da arte, na qual se insere como poeta-improvisador, guiado pelas regras da escrita e da oralidade, em um só tempo. Além disso, a apreciação de sua obra por um amplo público o coloca na história da literatura como poeta menor cuja 
poética não traz a dificuldade requerida para a apreciação e compreensão, o que é propiciado, ainda, por sua tomada popular.

Nesse sentido, Luís Câmara Cascudo ${ }^{23}$, com seu olhar de folclorista e etnólogo, é um dos únicos críticos a ressaltar aspectos da oralidade e do popular como positivos na obra de Caldas, considerando a obra Viola de Lereno, a mais comentada pelos críticos, a grande obra do autor (Cascudo, 1986, p. 21-23), em detrimento das outras, em que se repetem os cânones portugueses.

\footnotetext{
Quem fala no Pe. Caldas Barbosa lembra unicamente a Viola de Lereno, coleção de suas cantigas oferecidas aos seus amigos, [...] Caldas levara do Brasil a sensibilidade nativa e a maneira uniforme e poderosa da expansão lírica do povo, quadrinhas com rimas simples, molhadas de sensualidade, de ardor amoroso, vivas em dengue, paixão e súplica (Cascudo, 1986, p. 15-16).
}

Embora empregue adjetivação imprecisa para tratar da obra de Caldas Barbosa, marca de seu tempo, Cascudo demonstra um aspecto que não costuma ser ressaltado positivamente pelos demais críticos, que consideram a faceta popular do poeta como algo que o deprecie. A oralidade da obra de Caldas desloca-a para os estudos das áreas de música e literatura oral. A depreciação de seus atributos orais e mesmo a incompreensão desses pelos estudiosos, que consideram a literatura apenas como o escrito, são responsáveis pela subalternização de sua obra no mundo das letras. Além disso, a habilidade de improvisação dos poetas caracterizados como populares é vista como um recurso facilitador pela crítica literária em geral e como um "mero automatismo baseado em habilidade mais coletiva que individual, própria de um gênero cuja essência é retórica, não poética" (Candido, [1950] 2000, vol. 2, p. 146).

${ }^{23}$ Vale lembrar que, após a Semana de Arte Moderna de 1922, Mário de Andrade e Luís Câmara Cascudo realizaram expedições por todo Brasil em estudos sobre as culturas populares de nosso país. 


\title{
Fora do prumo
}

O hibridismo que caracteriza a obra de Domingos Caldas Barbosa, sintetizado pela presença de elementos oriundos, em sentido amplo, tanto da cultura erudita quanto da cultura popular, remete-nos à questão do cruzamento de culturas, vista como problemática desde nossos inícios coloniais, em que as lutas por poder e dominação de uma elite tornaram a cultura um elemento hierarquizável, havendo um contínuo crescente da cultura popular em direção à erudita. No Brasil, segundo Alfredo Bosi,

\begin{abstract}
o critério erudito em causa conhece uma história própria, que mergulha nas lutas culturais da matriz europeia: é a oposição entre as Luzes com seus padrões neoclássicos e o "obscurantismo" barroco, devoto e semipopular, visto sumariamente como um todo a ser superado. $\mathrm{O}$ espírito dessa luta, quando penetra a ideologia da classe dominante no país colonizado, se manifesta sob a forma de julgamentos cortantes dos outros estratos culturais, não só puramente populares como também os que se exprimem na fronteira entre o iletrado e o culto. O elitismo se tornaria, assim, um componente inarredável do processo ideológico latinoamericano na medida em que as ideias gerais da evolução, progresso e civilização não se casavam com os valores da democracia social e cultural. O gosto oficial do século XIX separou, por força da própria divisão de trabalho e de poder, os valores do colonizador e do colonizado, decaídos a não valores. Assim, o colonizado viveu sempre ambiguamente o seu próprio universo simbólico, tomando-o como positivo (em si) e negativo (para o outro e para si como introjeção do outro) (Bosi, 1992, p. 59-60).
\end{abstract}

Sob a égide da ideologia colonial à qual Bosi se refere acima, não poderiam Domingos Caldas Barbosa e outros escritores e escritoras brasileiros desse período, que produziam uma obra ora popular ora na "fronteira entre o iletrado e o culto", tal como Bosi conceitua, serem aceitos pela então crítica literária e mesmo pelas seguintes, até mesmo porque o movimento da crítica literária brasileira é, em suma, autoalimentar-se continuamente. Observa-se uma repetição de autores e títulos em diferentes obras de história literária. Embora se coloquem em oposição metodológica e ideológica, parte significativa dessas obras historiográficas reitera os mesmos valores literários eurocêntricos, escriptocêntricos e elitistas, tal como se observa nas obras de Haroldo de Campos, O sequestro do barroco na formação da literatura brasileira: o caso Gregório de Matos (1989) e Formação da literatura brasileira (1950), de Antonio Candido. A esse respeito argumenta Eduardo Coutinho:

O que fizeram, conscientemente ou não, foi estender a outras literaturas os parâmetros instituídos a partir de reflexões desenvolvidas sobre o cânone literário europeu (e por europeu entenda-se o cânone constituído 
basicamente por obras literárias das potências econômicas do oeste do continente). O resultado inevitável foi a supervalorização de um sistema determinado e a identificação deste sistema - o europeu - com o universal (Coutinho, 1996, p. 68).

O olhar da crítica, de elite, para essas poéticas banhadas por atributos populares, é de exclusão, pois estas representam o que tem de ser superado para a fixação de uma grande arte erudita, não havendo espaço para a confluência de culturas no âmbito literário, haja vista que se trata de uma luta pelo estabelecimento de pressupostos políticos e estéticos calcados em ideias coloniais de subjugação, e não de democratização.

Esse é o posicionamento da crítica literária que, em parte, é repetido por produtores e agentes literários que estão sendo julgados depreciativamente por suas obras "popularescas", como boa parte da crítica erudita e elitista que então os conceitua. Trazendo o exemplo de Caldas Barbosa, que reitera a divisão hierárquica realizada pelos estudiosos de literatura na compreensão de sua arte, dividindo-a em arte menor, popular, e arte maior, erudita, podemos observar que o poeta adota essa concepção como forma de "submissão estratégica".

"Submissão estratégica" - expressão cunhada aqui em analogia aos conceitos de "resistência cotidiana"24, de James C. Scott (2011), e "posicionalidade estratégica" ${ }^{25}$, de Judith Butler (1993) - refere-se às estratégias de resistência e autoafirmação realizadas constantemente no âmbito das poéticas periféricas e populares para afirmar uma identidade naturalizada e essencializada por intermédio de discursos aparentemente calcados na aceitação de submissão e inferioridade em face das poéticas do centro e eruditas. Contudo, esses discursos apresentam-se como expressões de questionamento e contestação que, por sua ambivalência semântica, ressoam significados a posteriori que aqueles que os produziram e deles fizeram uso a priori talvez nem pudessem prever.

\footnotetext{
${ }^{24}$ Conforme as ideias de Scott (2011, p. 242-243), resistência cotidiana é a "expressão da luta prosaica e constante entre os integrantes das classes dominadas e aqueles que deles buscam extrair trabalho, comida, impostos, rendas e juros. Ela se expressa na forma de corpo mole, dissimulação, falsa aquiescência, furto, ignorância fingida, calúnia, incêndio ou sabotagem. Assim, a ausência de formas mais visíveis de oposição política, como rebeliões ou greves, não reflete uma 'hegemonia' ideológica e a aceitação passiva da ordem estabelecida pelos dominados, e sim circunstâncias - que são mais a regra do que a exceção - em que uma ação aberta e organizada seria demasiado perigosa".

25 Judith Butler (1993) elabora a noção de "posicionalidade estratégica" em resposta ao conceito de "essencialismo estratégico" desenvolvido por Spivak, com o intuito de evidenciar os perigos políticos do uso dos signos identitários, que podem assumir ao longo do tempo diferentes significados e usos.
} 
Essa submissão estratégica se expressa na forma de justificações pela pequenez da poética popular em relação à grande literatura, as quais se recobrem, de maneira estratégica, com certa ironia e dissimulação, que desdizem os pressupostos de submissão e inferioridade. A ausência de expressões mais evidentes de rivalidade e enfrentamento, como o questionamento direto às verdades estabelecidas pelo discurso da crítica hegemônica, não indica concordância passiva ao discurso hegemônico, mas circunstâncias em que um enfrentamento direto inviabilizaria a existência dessas vozes populares e periféricas.

Os pressupostos de submissão e inferioridade são, ao mesmo tempo, idealizados negativamente no meio erudito e empregados estrategicamente no meio popular e marginal, cuja concordância com esses pressupostos consiste em um posicionamento pragmático em meio à estrutura hierárquica estabelecida entre os distintos meios culturais. A submissão estratégica, todavia, apresenta limites quanto a seu alcance, haja vista que, ao se evitar o embate direto, perpetuam-se esses esquemas hierárquicos e distintivos entre erudito (grande) e popular (pequeno) em nossa historiografia literária, não sendo questionados de maneira aberta os pressupostos estéticos da literatura.

Essa problemática pode ser analisada, por exemplo, no romance Úrsula (1859), de Maria Firmina dos Reis. No prólogo, a autora caracteriza seu livro como "mesquinho e humilde", "que pouco vale", "pobre avezinha silvestre", "sem dotes da natureza, nem enfeites e louçanias d'arte" (Reis, [1859] 2004, p. 13 e 14). A caracterização do livro vem acompanhada da qualificação de sua autora como carente e modesta,

porque escrito por uma mulher, e mulher brasileira, de educação acanhada e sem o trato e conversação dos homens ilustrados, que aconselham, que discutem e que corrigem, com uma instrução misérrima, apenas conhecendo a língua de seus pais e pouco lida, o seu cabedal intelectual é quase nulo (Reis, 2004, p. 13).

Embora defina nesses termos a si e a sua obra e anteveja, em relação à recepção da crítica literária, "o indiferentismo glacial de uns e o riso mofador de outros", a escritora concebe, escreve e publica sua obra, o que faz, segundo ela, para que "sirva esse bom acolhimento de incentivo para outras" (Reis, 2004, p. 14), tendo consciência de seu papel na história da literatura escrita por mulheres. 
Em nossa literatura oficial e hegemônica, "há poucas mulheres, quase nenhum não branco e muito provavelmente escassos membros dos segmentos menos favorecidos da pirâmide social" (Reis, 1992, p. 73) e, sabendo disso, diversos escritores usam de uma submissão estratégica para posicionarem-se na história. Além de Caldas Barbosa e Maria Firmina, podemos citar Luiz Gama (1830-1882), poeta negro, ex-escravo, que publicou em São Paulo, já em um contexto de luta para a abolição da escravatura, poemas com base popular e oral. Abaixo, trecho do poema chamado Prótase:

\author{
No meu cantinho, \\ Encolhidinho, \\ Mansinho e quedo, \\ Banindo o medo, \\ Do torpe mundo, \\ Tão furibundo, \\ Em fria prosa Fastidiosa - \\ O que estou vendo \\ Vou descrevendo. \\ Se de um quadrado \\ Fizer um ovo \\ Nisso dou provas \\ De escritor novo.
}

Sobre as abas sentado do Parnaso,

Pois que subir não pude ao alto cume,

Qual pobre, de um Mosteiro à Portaria

De trovas fabriquei este volume.

Vazios de saber, e de prosápias

Não tratam de Ariosto ou Lamartine

Nem rescendem as doces ambrosias

De Lamires famoso ou Aretine

São ritmos de tarelo, atropelados,

Sem retro, sem cadência e sem bitola

Que formam no papel um ziguezague,

Como os passos de rengo manquitola.

Grosseiras produções d'inculta mente

Em horas de pachorra construídas;

Mas filhas de um bestunto que não rende

Torpe lisonja às almas fementidas (Gama, 1860?).

Atualmente se observam, ao mesmo tempo, duas tomadas de posição por parte de produtores e produtoras literários ligados à oralidade, preocupados tanto em afirmar sua história face ao passado, ao presente e ao futuro de sua poética - assim como fez Maria Firmina dos Reis - quanto em afirmar sua produção literária como dotada de valor literário e social, o que a escritora fez apenas indiretamente por questões de conjuntura histórica e política. 
Escritores e escritoras que, como Maria Firmina dos Reis, foram obliterados da historiografia literária brasileira oficial, ou tratados como de segunda ordem, deixaram provas ou vestígios de sua existência, embora tenha havido um grande esforço de homogeneização de nossa literatura, em especial a partir dos pressupostos de hegemonia, hierarquia e distinção plantados desde tempos coloniais. Segundo Alfredo Bosi (1992, p. 62),

\begin{abstract}
estrutural é a compresença de dominantes e dominados, e estrutural é sua condição. O olho do colonizador não perdoou, ou mal tolerou, a constituição do diferente e a sua sobrevivência. A rigidez ortodoxa selada pelo Concílio de Trento abominava as danças e os cantos afro-brasileiros. Mais tarde, o gosto acadêmico de molde francês desprezaria a maneira arcaico-popular do barroco mineiro ainda sobrevivente na arquitetura religiosa do século XIX. Sempre uma cultura (ou um culto) vale-se de sua posição dominante para julgar a cultura ou um culto do outro. A colonização retarda, também no mundo dos símbolos, a democratização.
\end{abstract}

A configuração de um embate, direto ou indireto, entre "dominantes e dominados" ou, em outras palavras, entre o mundo popular e oral e o erudito e da escrita já é, em si, uma prova das constantes tentativas de supressão da cultura popular e oral, assim como apontam Bosi (1992) e Schüler (2001), e de resistência, mesmo que sob forma de submissão estratégica. Antonio Candido ([1950] 2000), por sua vez, naturaliza e aceita as premissas e valores da colonização, quando, por exemplo, não compreende o Barroco em seu estudo da formação da literatura brasileira, o que se dá também em razão das influências populares e orais presentes nesse movimento literário que descaracterizam esse momento como formador de nossa literatura. Nesse sentido, Flávio Kothe argumenta que

\footnotetext{
se há mais de duas literaturas na produção literária no Brasil, mais de duas historiografias deveriam existir: as exegeses canônicas - de Sílvio Romero, José Veríssimo, Antonio Candido, Afrânio Coutinho, Alfredo Bosi e similares - são, apesar de suas diferenças, antes continuações, complementações e variantes de um mesmo esquema fundamental e de um único cânone do que aberturas para outras 'literaturas' além dessa primeira (Kothe, 1997, p. 141).
}

A reiteração "de um mesmo esquema fundamental", com base em valores e julgamentos estéticos homogêneos atrelados à cultura erudita e à escrita, ao objetivar construir uma única história literária e um único cânone, rechaça a literatura popular e oral, o que ocorre desde o estudo das primeiras manifestações e movimentos literários brasileiros, prolongando-se, assim, uma história de diferenciação hierárquica de culturas iniciada já nos primórdios de nossa literatura, em nosso 
período colonial. Nesse sentido, conforme afirma Schüler (2001, p. 22), "distinguir certa literatura, diminuindo as demais, é perpetuar a colonização" e sua história de obliteração e subjugação face às poéticas dissonantes da oficial.

Tania Navarro-Swain atesta, nessa direção, que

\begin{abstract}
as narrativas históricas, de fato, imprimem um sentido e uma coerência ao caótico movimento do real, escondendo, no mesmo movimento, a construção que a ordena. As "narrativas-mestras" da história, os clássicos, generalizando abusivamente sua interpretação do social, ocultam os pressupostos que as orientam, os valores e representações modeladoras de percepções, construindo uma realidade histórica homogênea, repetidora do mesmo, em discursos cuja pretensão é espelhar o real (Navarro-Swain, 2006).
\end{abstract}

A homogeneidade das produções literárias brasileiras é fundamentada pela historiografia literária e por seus pressupostos teóricos e metodológicos trazidos da cultura ocidental, de acordo com os quais, por exemplo, a literatura consiste em uma produção passível de periodização. A periodização literária toma como referência os movimentos artísticos e literários europeus e, por conseguinte, considera as produções literárias das colônias como meras repetições e adaptações dos colonizadores, desconsiderando-se a diversidade de tradições culturais e universos sociais, consideradas manifestações menores, cópias dos modelos do colonizador.

Assim como a periodização literária, a tradição literária consiste em outro acervo a ser alimentado exclusivamente por obras que a afirmem, reforcem, solidifiquem, legitimem e perpetuem o que constitui e constituirá o cânone literário. A continuidade produzida pela autoalimentação contínua da crítica e história literárias exclui os dessemelhantes, em nome, por exemplo, da evolução dos períodos e gêneros literários.

A perduração desses parâmetros de avaliação implica a exclusão, no âmbito da historia literária oficial, de outras possibilidades de literatura, bem como a marginalização de diferentes tradições literárias. As obras dos escritores e escritoras que Candido e Bosi, assim como outros estudiosos de literatura, caracterizam por ser "de segunda linha" e que, por assim serem entendidas, não integram o cânon literário, podem ser tomadas, contudo, como lampejos à criação de outras historiografias e de outras tradições culturais e literárias, em um movimento que vai contra a coerência de um todo homogêneo e em direção à multiplicidade de produções. Conforme defende Mignolo (2003, p. 108), 
sociedades silenciadas são, é claro, sociedades em que há fala e escrita, mas que não são ouvidas na produção planetária de conhecimento, orientadas pelas histórias locais e as línguas locais das "sociedades silenciadoras" (isto é, desenvolvidas).

Conforme defende Walter Mignolo, há um processo de silenciamento, e não uma ausência. Pensamento análogo é desenvolvido pelo estudioso português Arnaldo Saraiva, já em 1975, em seu livro denominado Literatura marginalizada, em que questiona o fato de o folheto de cordel ser posto à margem por um campo e um sistema literários que o desprezam e que apenas repetem a mesma história literária dos cânones oficiais. O autor constrói o argumento de que o cordel é uma literatura marginalizada, e não marginal, ou seja, não são seus atributos intrínsecos que a qualificam como marginal, pequena, simples, mas sim um longo processo discursivo, no âmbito da crítica e da história literárias, de subjugação e marginalização dessa poética.

Bernard Mouralis desenvolve o conceito de contraliteraturas, em que também aponta em direção a esse tipo de "texto que não seja entendido e transmitido - num determinado momento da história - como pertencente à literatura" (Mouralis, 1982, p. 43) $)^{26}$. De acordo com o autor,

\begin{abstract}
os textos que a instituição literária recusa e que, por essa razão, não entram no domínio do literário, não são apenas textos à margem da "literatura" - ou inferiores a esta -, mas também textos que, só com sua presença, constituem já uma ameaça para o equilíbrio do campo literário, visto que assim revelam tudo o que nele há de arbitrário. "Literatura" e contraliteratura, muito mais que "literatura" e não literatura. (Mouralis, 1982, p. 12-13).
\end{abstract}

O termo contraliteraturas - bem como literatura marginalizada - retira conceitualmente as produções literárias dissonantes da "literatura" de uma posição de simples negação constitutiva e as coloca em posição de negação combativa, o que inverte a ordem de valores estabelecidos historicamente em relação a poéticas distintas das oficiais e canônicas. A ameaça e a desestabilização constituem forças dessas poéticas contrárias, que ativam essa posição apenas com sua mera presença.

Essa questão também é levantada por Jacques Derrida, em um contexto filosófico, quando ele desenvolve a ideia de suplemento, o qual designa a "criação de

${ }^{26}$ Contraliteraturas é uma noção firmada em relação, em referência e em oposição à de literatura oficial, de modo que só fica de pé se aceitarmos a priori a existência de uma literatura oficial como central, o que é feito sem questionamentos por nossa crítica e historiografia literárias dominantes. 
um universo que se acrescenta ao universo" (Derrida, 1995, p. 19). Para o autor, o suplementar é parte fundamental daquilo que suplementa e indica que nesta há uma falta essencial, em que o suplemento preenche essa lacuna, participante e transgredindo o universo já estabelecido (Derrida, 1999).

As literaturas marginalizadas, contraliteraturas, literaturas populares e de bases orais, por serem suplementares ${ }^{27}$, no momento em que vivemos, em nossa tradição e historiografia literárias, nos permitem pensar em histórias e historiografias ainda não escritas, ainda no reino das impossibilidades, enquanto abstrações discursivas e lampejos existenciais, críticos e teóricos que nos façam buscar incessantemente multiplicidades, diversos, para escaparmos dos perigos da história única, nos termos de Chimamanda Adichie (2009), de uma literatura única, segundo a percepção de Ria Lemaire (1994), “da tirania do unívoco, do homogêneo, da monótona repetição do mesmo" (Navarro-Swain, 2006).

Dessa forma, a concepção fundamentada pelo colonialismo segundo a qual era impossível a articulação de literaturas marginalizadas e contraliteraturas pode ser hoje enfrentada com a possibilidade, sempre buscada, de se realizar múltiplos diálogos culturais.

\footnotetext{
${ }^{27}$ Movimento similar foi e contínua sendo realizado por pesquisadores que se debruçam sobre a literatura afrobrasileira, que apresenta percurso similar ao do cordel. Em 2011, foi publicada a coleção Literatura e afrodescendência no Brasil: antologia crítica, em quatro volumes, com organização de Eduardo de Assis Duarte e Maria Nazareth Soares Fonseca. Essas obras são a corporificação da ideia de suplemento em nossa atual história literária e sinalizam um caminho de produção e estudo crítico.
} 


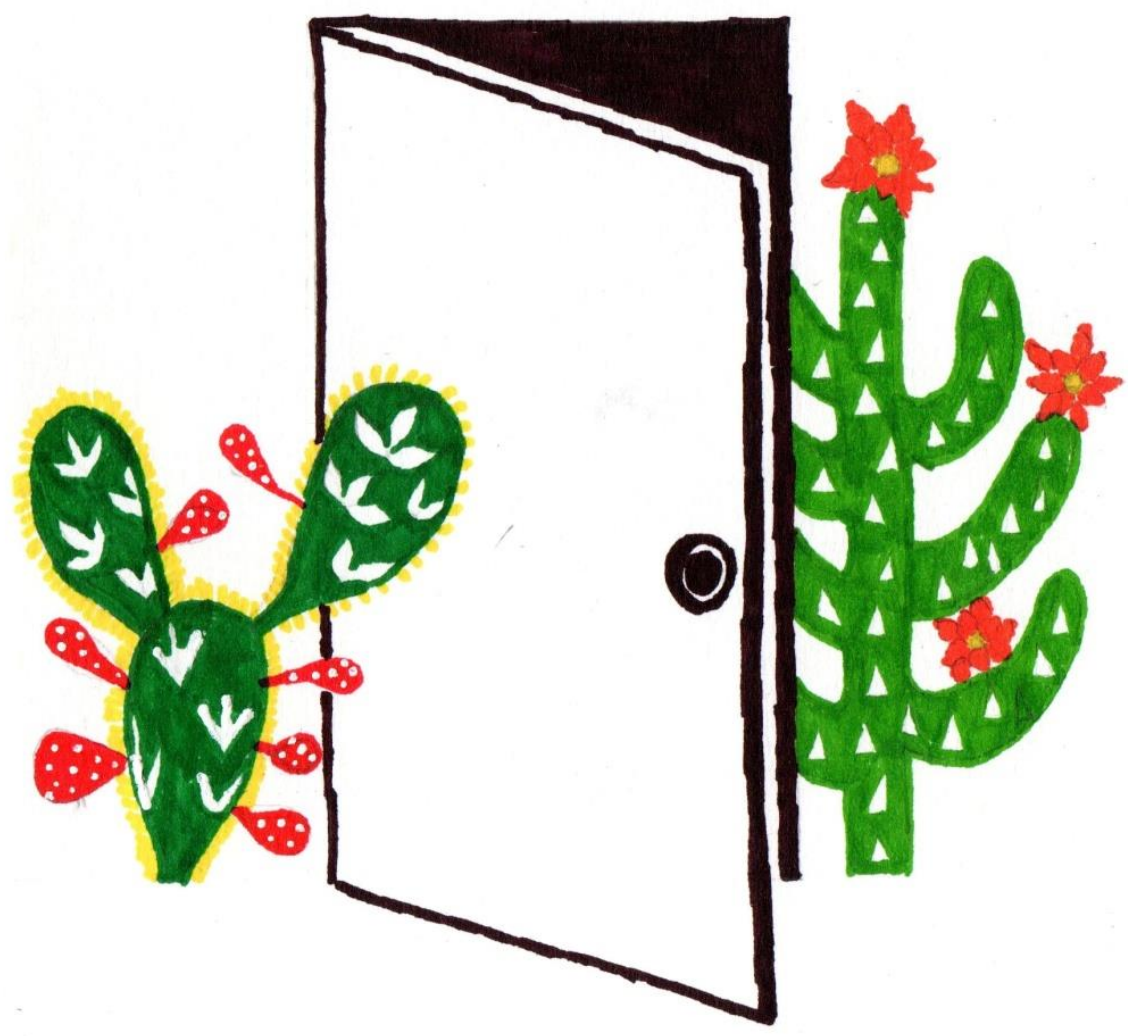

I I _ OS GABINETES: PORTAS SEMICERRADAS 
Somente o rico na Terra

tem o seu nome na história

quanto o pobre vence a

guerra

o rico alcança a vitória.

Patativa do Assaré

Trilhando os caminhos fixados pela história, teoria e crítica da literatura oficial e hegemônica, o que conhecemos por Literatura não apenas foi escrito, em sua grande maioria, por uma elite artística e intelectual, como também foi regido por suas normas, padrões e correntes, formando-se um cânone. O passar do tempo, porém, mostra que o que é muitas vezes rechaçado em uma determinada época, pode ser alçado como integrante do cânone e da história literária em outro momento, mas, mesmo que "sanadas" as injustiças de gerações, há determinadas obras literárias que a simples passagem do tempo não consegue resgatar à história literária. Os motivos podem ser vários, mas, em se tratando de poéticas populares, pode girar em torno de apenas uma questão: a eterna peleja entre intelectuais e escritoras e escritores populares, em que os territórios de cada esfera - popular e erudita (ou sem nenhum adjetivo) - são milimetricamente marcados, como Patativa do Assaré sugere no título de seu poema "Cante lá que eu canto cá".

Ao ler a crítica literária brasileira, responsável pela legitimação e fixação de uma visão sobre o literário, sendo ela estética, formal ou ideológica, percebemos que em sua base está forjado o conceito de uma literatura ao mesmo tempo nacional e universal. O principal responsável por essa perspectiva é o crítico literário Antonio Candido, sob a influência de Sílvio Romero, mas não se pode esquecer da posição de José Veríssimo, com a postulação da dialética do local (nacional) e do universal como o processo responsável pela formação da literatura brasileira (Candido, 2006, p. 169-96). Também o modernista Oswald de Andrade (1890-1954), com o conceito de antropofagia, perseguia a dialética do local versus o universal, na qual a busca pelo ideário de nação é norteador. Mário de Andrade (1893-1945) realiza esse movimento mesmo recusando o termo antropofagia.

Todavia, essa dinâmica entre local e universal serviu para legitimar apenas algumas obras literárias, ao passo que deslegitimou e silenciou muitas outras. No caso específico do cordel, sua exclusão ocorreu mais por ser relacionada a uma produção popular e oral do que por sua temática, com cunho majoritariamente nacional. Assim, a historiografia literária brasileira que "como um discurso sobre a 
formação, composição e definição da nação, haveria de permitir a incorporação de múltiplos materiais alheios ao círculo anterior das belas letras que emanavam das elites cultas" (Rama, 1984, p. 93), restringiu-se a gêneros literários advindos de uma elite intelectual e cultural sob a ideia de construir uma "grande" literatura da qual, apesar da hibridização e dialética entre o local e o universal, adviessem valores formais, estéticos e temáticos universais.

O caráter universal, em sua origem, atrelou-se a questões estéticas, visto que elas foram vistas como as únicas capazes de distinguir a verdadeira obra de arte e assegurar-lhe universalidade e atemporalidade. Theodor Adorno, um dos mais importantes teóricos de seu tempo, postulou que a pureza da obra de arte "foi obtida desde o início ao preço da exclusão das classes inferiores" (Adorno, 1985, p. 127). De modo que, segundo Adorno, a grande obra de arte deve-se manter fiel à "verdadeira liberdade da arte", em detrimento à "falsa liberdade", que residiria na ampla participação das diferentes classes sociais na construção e consumo da obra artística.

O motor da "verdadeira" e da "falsa" universalidade e, por conseguinte, a "verdadeira" e a "falsa" obra de arte foram entendidos por Pierre Bourdieu não como um dado "puro" e "factual" - como para Adorno - mas como "uma invenção histórica correlata da aparição de um campo de produção artística autônomo, ou seja, capaz de impor suas próprias normas, tanto na produção quanto no consumo de seus produtos" (Bourdieu, 2007, p. 11). Dessa forma, enquanto Adorno atribuiu ao julgamento estético a premissa de um "olhar puro", Bourdieu o colocou em xeque, revelando os valores subjacentes ao considerado arte e literatura.

\footnotetext{
O produtor do valor da obra de arte não é o artista, mas o campo de produção enquanto universo de crença que produz o valor da obra de arte como fetiche ao produzir a crença no poder criador do artista. Sendo dado que a obra de arte só existe enquanto objeto simbólico dotado de valor se é conhecida e reconhecida, ou seja, socialmente instituída como obra de arte por espectadores dotados da disposição e da competência estéticas necessárias para a conhecer e reconhecer como tal, a ciência das obras tem por objeto não apenas a produção material da obra, mas também a produção do valor da obra ou, o que dá no mesmo, da crença no valor da obra (Bourdieu, 1996, p. 259).
}

Como podemos perceber, a pretensa universalidade proposta por Adorno como certificado de arte à obra literária não é dada somente por sua "produção material”, mas também pela "produção de seu valor", que não é objetivo, nem puro, 
nem isento de jogos de poder. É nesse campo, em que se constrói o valor da obra de arte, que se constrói também o que não tem valor artístico. O que afirmou Jésus Martin-Barbero a respeito de diferentes culturas cabe perfeitamente à conceituação do que é e do que não é considerado literatura: "O sentimento de in-cultura se produz historicamente só quando a sociedade 'aceita' o mito de uma cultura universal, que é por sua vez o pressuposto e a aposta hegemônica da burguesia, esta classe pela primeira vez universal" (Martin-Barbero, 2003, p. 146).

Apostando-se na hegemonia como mecanismo de legitimação de si e de deslegitimação do outro, o que hoje conhecemos por intelectualidade firmou-se como centro de poder simbólico tendo em suas mãos o carimbo de atribuição de valor às coisas. Nesse sentido, Gramsci elaborou o conceito de hegemonia, que é entendido como um processo de dominação social no qual uma classe se sobrepõe às classes subalternas pela defesa de seu poder e de seus interesses (Gramsci, 1968, p. 329).

Em um primeiro momento, o clero é quem exerce o papel de intelectualidade, "na medida em que é praticamente a única personagem histórica que tem acesso à cultura" (Silva, 2006, p. 154) e que utilizou a palavra escrita como fonte de prestígio e legitimação. Com a instauração da Inquisição, buscou-se unificar o idioma bem como condenar superstições e tudo mais que ameaçasse a constituição de um poder (cultural) central. Principalmente entre 1550 e 1650, além de unificados costumes e tradições, como já dito, muitos foram totalmente abolidos pela igreja, tanto pela católica como pela protestante (Burke, 1989, p. 245-6.). Seria errôneo sugerir que a igreja exercia um poder sem que houvesse resistência, mas, ao que consta na leitura desse período e das consequências que ele gerou, a hegemonia e a liderança da reforma da cultura popular partiram de intelectuais, em especial de clérigos.

Isso só foi possível com o estabelecimento da hegemonia da cultura escrita em detrimento da cultura oral pelo clero e com a organização das pessoas em cidades, como um estudo de Angel Rama, A cidade das letras (1984), postula. Desse entrelaçamento, entre escrita e urbanização, nasce o que Rama chamou de cidade das letras, entendida como a grande responsável pelo estabelecimento da classe-posiçãoprofissão que denominamos intelectualidade.

Se coube ao clero, num primeiro momento, a afirmação de uma intelectualidade, o próximo passo foi dado por intelectuais leigos, quando adquiriram certa autonomia dos poderes religiosos e estatais absolutistas e, sobretudo, quando 
começaram a escrever aos seus pares - configura-se aí o intelectual tal qual o concebemos atualmente. Segundo Angel Rama,

\begin{abstract}
para levar adiante o sistema ordenado da monarquia absoluta, para facilitar a hierarquização e concentração do poder, para cumprir sua missão civilizadora, acabou sendo indispensável que as cidades, que eram a sede da delegação dos poderes, dispusessem de um grupo social especializado ao qual encomendar esses encargos. (...) Ambas as esferas estiveram superpostas por longo tempo, fazendo com que a equipe intelectual contasse durante séculos entre suas filas com importantes setores eclesiásticos, antes que a laicização que começa sua ação no século XVIII fosse substituindo-os por intelectuais civis, profissionais na sua maioria (Rama, 1984, p. 41).
\end{abstract}

Assim é concretizada uma intelectualidade, e o verbo "evangelizar" é substituído pelo "educar" por meio dos novos guardiões do saber (Rama, 1984, p. 37). Vale ressaltar que nesse processo de transição de poder, houve grupos híbridos, como a Companhia do Sagrado Sacramento, composta de clérigos e leigos (Burke, 1989, p. 262).

Com a passagem do poder às mãos de leigos, os argumentos contra a cultura popular mudam de tom. Enquanto a igreja desejava reformar a cultura popular em nome da moralidade e da religião, os intelectuais leigos o faziam em defesa do apuro estético. Um exemplo disso é quando Johann Christoph Gottsched, professor de poética em Leipzig, lutou contra o teatro popular de sua época, mas especificamente o de Hans Wurst e Arlequim, em nome não da moral, mas do bom gosto, já que se tratava de personagens e representações populares. Além disso, o professor protestou contra peças que quebravam as regras de Aristóteles e contra atores que tomavam liberdades com o texto, até que em 1737 conseguiu expulsar Arlequim dos palcos (Burke, 1989, p. 262).

A defesa desse bom gosto e apuro estético ocorreu justamente no momento em que a tradição cultural escrita se estabeleceu como signo maior de cultura e intelectualidade, uma vez que somente a partir da acumulação e da leitura do conhecimento produzido, o intelectual (no masculino) foi definido e postulado como tal. Esse dado permite observar que, em nossa sociedade, a tradição oral foi marginalizada e abandonada em detrimento da tradição escrita; concepção que permanece até os dias atuais sob diversas formas, em especial na cisão entre culturas populares e eruditas. 


\section{0 critério escriptocêntrico}

A formação do conceito do que se denomina intelectual está repleta de tomadas de posição, que muitas vezes se escondem na ilusão de um transcurso sem jogos de força e poder. O que não se verifica na leitura atenta de nossa história, uma vez que, no momento da construção da intelectualidade, "foram subestimadas as numerosas tradições orais das línguas vernaculares" (Burke, 1989, p. 60). Além de subestimadas, elas foram apropriadas. Um exemplo esclarecedor a este respeito é a figura do trovador medieval. Na Idade Média europeia, com o surgimento da tecnologia da escrita, os trovadores começaram a ditar seus versos a um escriba a fim de que estes os entregassem a damas. Importantes documentos a este respeito são as 16 iluminuras do Cancioneiro da ajuda ${ }^{28}$ que retratam como o fazer poético era produzido, fixado e divulgado. As iluminuras apresentam, de um lado, o trabalho do trovador, responsável por compor os versos, e de outro, o trabalho dos jograis, ou seja, de cantar, tocar instrumentos e dançar.

Não obstante, pesquisas recente ${ }^{29}$ apontam para o fato de que o trovador, homem nobre e de elite, como controlador da produção e da divulgação da palavra poética, apropriou-se da poesia feita pelos "mestres tradicionais da palavra", os jograis, pessoas do povo, na medida em que dispunham dos meios para selecionar, ordenar e pagar os artistas para a execução das obras, ademais, para a registrarem na forma escrita. Dessa forma, como Slavoj Žižek afirma, "toda posição dentro do todo social é sobredeterminada, em última instância, pela luta de classes" (Žižek, 2007, p. 27). Mais ainda, os antigos poetas eram, em sua quase maioria, cavaleiros pobres que, por estarem na presença da nobreza, eram alçados a nobres, visto que "o refinamento e a cultura começam a transformar-se em agente nivelador na medida em que príncipes e outros nobres se orgulham de contar-se entre os trouvères" (Mannheim, 1974, p. 99).

${ }^{28}$ O Cancioneiro da Ajuda, que recebe este nome por estar conservado na biblioteca do Palácio Nacional da Ajuda em Lisboa, é um dos três manuscritos de cancioneiros que conservam a poesia medieval portuguesa. Este cancioneiro, em especial, contém cantigas de amor em suas 16 iluminuras que retratam o funcionamento dessa poesia com seu canto, dança e declamação. A esse respeito, ver: Vasconcelos, 1990.

${ }^{29}$ A medievalista Ria Lemaire, em sua tese de doutorado Passions et Positions: contribution pour une sémiotique du sujet dans la poésie lyrique en langues romanes, debruça-se sobre a problemática entre oralidade, escrita e poder. 
Como o exemplo dos trovadores revela, há um momento em que o povo é privado de seus instrumentos de produção (no caso, a voz é substituída, em certa medida, pela escrita) e uma elite, que não fazia este trabalho, passa a organizá-lo. Assim, nascem os trovadores e são esquecidos os jograis. Como foi mostrado, na história literária, desde a fixação da cultura escrita, o que nos chega como autores da Literatura são os nobres e ricos trovadores.

Eric Havelock, estudando a oralidade e a cultura escrita grega, em sua obra $A$ musa aprende a escrever: reflexões sobre a oralidade e a literacia da Antiguidade ao presente, de 1988, defendeu a ideia de que o transcurso, que foi lento e gradual, da oralidade à cultura escrita, foi renegado em detrimento à concepção de uma substituição, a um só golpe, da oralidade pela escrita em grande parte dos estudos literários, o que ocasionou a depreciação da oralidade como suporte do discurso artístico e mesmo intelectual.

Antes dos estudos de Havelock, desde o século XVIII, sabia-se que os "poemas de Homero foram compostos e recitados sem a ajuda de letras" (Havelock, 1996, p. 69), como postula a obra do filólogo F. A. Wolf, Prolegomena ad Homerun ([1795] 1988). Mas é só em 1928, que o pesquisador americano Milman Parry, em L'epithète tradicionelle dans Homero, defendeu que Ilíada e Odisseia foram produzidas oralmente, sem a ajuda da escrita (Havelock, 1996).

As epopeias de Homero eram composições da oralidade primária, isto é, "a sua existência e forma textuais representavam uma restituição fidedigna de leis puramente acústicas da composição, na medida em que estas regulavam não só o estilo, como também conteúdo" (Havelock, 1996, p. 23). Assim, as obras inaugurais da tradição literária escrita e hegemônica nada mais são do que transcrições da oralidade primária, já que a escrita serviu, neste primeiro momento, apenas para fixar a própria oralidade. Como a substituição da oralidade pela escrita foi lenta e gradual, a tecnologia da escrita foi usada por muito tempo para transcrever a oralidade.

Na direção desses estudos sobre a poética de Homero, também são publicadas The bias of communication (1951), de Harold Innis; The Singer of tale (1960), de Albert Lord; A study of writing (1952), de Ignace J. Gelb; e Ramus: method and decay of dialogue (1958), de Walter J. Ong. Os estudos da oralidade, no entanto, consolidaram-se a partir de cinco importantes obras, publicadas entre os anos de 1962 e 1963, na Grã-Bretanha, França e Estados Unidos da América. São elas: La pensée sauvage (1962), de Claude Levi-Strauss; The Gutenberg galaxy (1962), de 
Marshall McLuhan; "The consequences of literacy" (1963), de Jack Goddy e Ian Watt; Animal species and evolution (1963), de Ernst Mayr; e Preface to Plato (1963), do próprio Eric Havelock.

Esses estudos, juntamente com o pensamento do medievalista Paul Zumthor, foram os responsáveis pela desconstrução da concepção de uma tradição literária hegemônica como um fenômeno somente escrito, dando a ver que a sociedade tornase letrada e que mesmo antes da instauração da cultura escrita como hegemônica, a oralidade era (e é) altamente desenvolvida, com seus próprios meios de composição, transmissão e publicação.

A literatura, em especial a poesia, que hoje é muitas vezes entendida como uma manifestação artística desprovida de fins práticos, é originalmente (na oralidade) a responsável pelo "armazenamento de informação cultural para a reutilização, ou, em termos mais familiares, o instrumento para o estabelecimento de uma tradição cultural" (Havelock, 1996, p. 90). Na oralidade primária, o especialista oral, ou seja, os bardos do povo, músicos, sacerdotes, videntes e profetas são os encarregados pela manutenção dessa memória e, transportando para a nossa atual organização social, os intelectuais da cultura oral.

Ao passo que na oralidade primária as pessoas tinham apenas sua memória como local de armazenamento do conhecimento - e a lembrança e a recordação são os alicerces do que se entende por civilização e intelectualidade -, com o desenvolvimento da cultura escrita ganha-se uma memória artificial por meio dos documentos. E quem podia produzir, ou mesmo acessar, esses documentos, os letrados, eram os intelectuais e, mais que isso, os cidadãos civilizados donos da palavra e, por isso, do poder.

\footnotetext{
Nos cem anos seguintes (à criação do alfabeto), a palavra escrita, crescentemente dominante à medida que a literacia (cultura escrita) europeia de massas avançava sob governos liberais ou democráticos, tornou-se o único contexto no interior do qual se consideravam os problemas da consciência e da comunicação. Quem não escrevesse nem lesse era, culturalmente falando, uma não pessoa (Havelock, 1996, p. 55).
}

E assim há claramente a separação entre a oralidade e a escrita. E, consequentemente, a cultura escrita torna-se a formadora e responsável pelo conhecimento e pela intelectualidade, por meio de um claro e objetivo mecanismo de distinção, em que a representação estritamente negativa da oralidade e do popular 
serve de contrapartida ao estabelecimento da cultura erudita e do escrito como superior e culto (Bourdieu, 2007, p. 35). Esse processo de distinção pode ser observado na mudança de significação da palavra logos:

\begin{abstract}
O termo lógos, ricamente ambivalente, que se refere ao discurso, quer falado, quer escrito (argumento versus tratado), e também à operação mental (o poder de raciocinar) requerida para a sua produção, tomou posse de si próprio, simbolizando o novo discurso prosaico e literário (apesar de ainda gozar de uma parceria necessária com o dialecto falado). Esta distinção, lentamente formada, identificava o epos (poema épico, epopeia) proferido do discurso oralmente preservado como algo diferente do lógos e (para os filósofos) que lhe era inferior (Havelock, 1996, p. 132).
\end{abstract}

Com a substituição da oralidade como fonte e local de armazenamento do saber pela cultura escrita, começa-se a difundir entre as classes pobres e populares, detentoras apenas do saber oral, o sentimento de incultura quanto à sua produção artística e cultural que, em contrapartida à cultura erudita - de intelectuais -, passa a significar apenas o atrasado, o vulgar e o comum.

\title{
0 caso do cordel
}

O cordel é, antes de tudo, uma parte das poéticas das vozes criadas e transmitidas por meio de uma multiplicidade de gêneros: cantoria, embolada, repente, coco, aboio, entre outras manifestações. Quando se fala em cordel, refere-se em especial à poesia popular impressa, e os folhetos são, tradicionalmente, os suportes que estabelecem a materialidade dessa poesia. Como afirma Candance Slater (1984), a expressão literatura de cordel é uma invenção ibérica, denominada assim pelo fato de os folhetos, em Portugal, serem presos por um pequeno cordel ou barbante ${ }^{30}$.

O que hoje conhecemos por cordel nem sempre teve essa designação. Entre as denominações utilizadas, até a primeira metade do século XX, estão "folheto", "livro de feira", "romance" e "livro de Athayde"31. Seus produtores e consumidores, até

\footnotetext{
${ }^{30} \mathrm{O}$ termo cordel, associado às "folhas volantes" ou "folhas soltas" lusitanas, já é usado no século XVII em Portugal, conforme registro de Teófilo Braga, assinalado por Diegues Junior, em Literatura de Cordel.

${ }^{31}$ A designação "folheto de Athayde" se dá por conta do grande reconhecimento desse poeta como cordelista.
} 
meados dos anos 1960, nem sequer reconheciam a palavra cordel como uma expressão que designasse esse gênero poético ${ }^{32}$.

No Brasil, registra-se o aparecimento dos primeiros folhetos de cordel a partir da segunda metade do século XIX. O mais antigo folheto com data que se tem notícia é A vida de Antônio Silvino, de 1904, escrito por Francisco das Chagas Batista e impresso em Recife, na Imprensa Industrial. $\mathrm{O}$ folheto de 16 páginas, em formato $1 / 4$, é composto por uma capa onde há a tradicional moldura orlada, com o título, a data de impressão, o nome da casa impressora e o preço.

O transporte da expressão cordel para o contexto brasileiro, principalmente nordestino, pode ser entendido como a primeira participação de um campo de intelectuais nessa poética. De acordo com Ria Lemaire (2007, p. 9), uma

\begin{abstract}
apropriação bastante míope, na verdade, mas bem dentro dos quadros do discurso escriptocêntrico das ciências humanas da época, voltadas exclusivamente para as formas escritas e impressas das línguas e das literaturas que por sua vez exprimiam e divulgavam geralmente a ideologia das elites e da sua relação com o poder.
\end{abstract}

Ao passo que significou também a primeira estratégia, por seus produtores, de legitimação do gênero, pois que, apesar de exporem seus folhetos em esteiras de palha e em bancadas móveis armadas em lugares públicos (daí a expressão "poeta de bancada"), eles passaram a utilizar essa forma de exposição e denominação como meio de difundir ainda mais sua produção e alimentar o folclore e a tradição criados pelos portugueses e adotados pelos intelectuais brasileiros em seus estudos a partir da década de 70 do século passado. Tendo o termo facilitado a circulação dos folhetos nos meios intelectuais, tornou-se mais vantajoso se render à expressão e até mesmo alimentá-la. E assim se disseminou a designação "literatura de cordel" entre os produtores e os consumidores do folheto brasileiro. Mas é, antes de tudo, o uso de um termo de origem erudita que revela um dos primeiros momentos em que se quis exercer o controle da significação dessa poética do povo, e também fixar uma terminologia conveniente aos padrões da crítica literária, sob a lógica de um controle. Por outro lado, a tomada desse termo pelos produtores indica um uso estratégico, na lógica da submissão estratégica.

\footnotetext{
32 Vilma Mota Quintela (2005) ressalta que há apenas um registro da expressão "literatura de cordel", anterior a 1950, que é usada pelo cordelista Francisco das Chagas Batista, em sua antologia Cantadores e poetas populares, de 1929. Em contrapartida, Chagas Batista emprega o termo "poesias populares", e não cordel, nas capas das edições dos folhetos.
} 
Segundo Idelette Muzart-Fonseca dos Santos, o primeiro intelectual brasileiro a utilizar a expressão "literatura de cordel" foi Sílvio Romero, em seu livro Estudos sobre a poesia popular do Brasil, de 1888, a partir da "evidência do exemplo português, ao qual seu mestre Teófilo Braga havia consagrado diversos estudos" (Santos, 1995, p. 31-43). A identificação com a poesia feita em Portugal, neste primeiro momento, foi ainda a responsável por traçar a genealogia do cordel brasileiro como portuguesa ${ }^{33}$. Hoje se sabe que em boa parte dos lugares do mundo essa poesia já era feita, mesmo antes de a tipografia chegar, por meio dos manuscritos (Lemaire, 2007). Com estruturas formais que podem variar um pouco de um lugar para outro, podemos ter como antepassados do cordel brasileiro as baladas orais, os desafios ou pelejas, a tenzone dos trovadores medievais, o trancoso, o romanceiro, os akipalôs de origem africana, o corrido na Espanha, entre outros, de modo que a identificação com o cordel lusitano foi preponderante nos estudos do cordel brasileiro apenas pela transposição imediata e apressada de historiadores e críticos da cultura.

$\mathrm{Na}$ atualidade, a estudiosa Márcia Abreu, em sua obra História de cordéis e folhetos, de 1999, faz o caminho inverso, ou seja, busca as diferenças e as dessemelhanças entre a literatura de cordel lusitana e a literatura de folhetos brasileira, reafirmando a especificidade e a independência de nossa produção. Questionando as origens lusitanas do folheto brasileiro, a autora considera possível apenas a aproximação entre literatura de cordel lusitana e literatura de folhetos brasileira quanto ao gênero editorial e não em relação ao gênero literário.

Os impasses quanto ao entendimento dessa poética não cessam por aqui. Quando se adentra no universo do cordel, a fortuna crítica sobre o tema, que se localiza no âmbito da cultura popular, é vasta. Já as perspectivas sobre a cultura popular não são tão vastas assim. Entendida por grande parte de estudiosos e estudiosas por meio de um conceito residual em que se opõe à grande e legítima cultura, carrega em sua denominação "popular" uma série de preconceitos. Por ser de outra tradição - popular, da oralidade - o cordel é muitas vezes estudado como gênero menor, folclore, e expressão de um “povo", constituído por pessoas pobres, moradoras de regiões periféricas que cantam e escrevem suas alegrias e agruras por

33 Algumas obras que defendem essa concepção: Batista (1973, p. 331-419); Curran (1973, p. 271310); Diegues Júnior (1973, p. 1-151). Vale observar que a Fundação Casa de Rui Barbosa foi a instituição promotora e publicadora de todas essas obras. 
meio do folheto de cordel. Assim, o que parece estar em jogo não é o que o artista produz, mas a crença que os estudiosos imbuem ao cordel e que o relega à posição de inferioridade no campo da cultura pela origem de seus autores e pela tradição cultural a que pertencem.

A designação do cordel como cultura popular ou literatura popular traz em seu bojo toda essa história. Vale ressaltar que antes de ser cunhado pelo adjetivo popular, o cordel foi concebido e estudado como manifestação folclórica ${ }^{34}$. A classificação do cordel como folclore foi feita a partir das seguintes premissas: uma obra sem autor, que versa sobre o conhecimento do "povo" - entendido como um ser coletivo e sem existência concreta; faz parte de uma tradição popular e é fruto de uma espontaneidade ingênua do povo.

Atualmente não mais se fala em estudos folclóricos, pois, como defende Carlo Ginzburg (1987), paira uma consciência pesada do colonialismo e a da opressão de classe, que alterou as formas de compreensão desse fenômeno. As produções das "classes subalternas" são vistas não mais como folclore, mas como cultura popular, uma vez que a noção de folclore destituía o "povo" de cultura.

O termo "popular", quando se refere ao cordel, muitas vezes carrega uma série de características: ser de autoria de pobres que veem de forma ingênua o mundo, ocupam profissões subalternas, possuem pouca ou nenhuma escolarização, escrevem/cantam por dom e não por arte - uma vez que esta é destinada apenas a escritores pertencentes a uma elite econômica e intelectual e que, portanto, possuem individualidade. Também se pode perceber que o cordel é considerado popular por um dado extraliterário: a origem do autor, o que "não se trata, falando com propriedade, de um critério objetivo, de um elemento que faria parte da própria obra, mas, antes, de um postulado e até de um ato de fé pressuposto em relação a qualquer exame concreto da própria obra" (Mouralis, 1982, p. 147). De alguma forma, o adjetivo "popular" marginaliza seu produtor, que não é associado ao campo de produção de arte, mas é apenas uma flor que brota no asfalto, ou no árido sertão.

Para afirmar-se a superioridade de poéticas eruditas, segregam-se, e mesmo deslegitimam-se, outras tradições culturais, como é o caso do cordel, por meio da

\footnotetext{
${ }^{34} \mathrm{O}$ conceito de folk-lore foi criado pelo arqueólogo inglês William Jhon Thoms (1803-1885), com o pseudônimo de Ambrose Merton, no artigo "Folk-lore", publicado na revista The Athenaeum, de 22 de agosto de 1846. Nesse artigo, o termo relaciona-se à antiguidade arqueológica dos seres humanos e ganha a acepção de "sabedoria" ou "ciência" do povo.
} 
desvalorização de seus atributos constitutivos - rima, ritmo, repetição, improvisação, memorização, entre outros - como recursos "pobres" e "menores". A respeito de rótulos como "folclore" e "popular", "menor", "pobre”, Pierre Bourdieu afirma:

\begin{abstract}
a maior parte das noções que os artistas e os críticos empregam para se definirem ou para definirem os seus adversários são armas e objetivos de lutas e muitas das categorias que os historiadores da arte utilizam para pensar seu objeto são apenas categorias nativas mais ou menos sabiamente disfarçadas ou transfiguradas. Estes conceitos de combate (...) tornam-se pouco a pouco em categorias técnicas a que, graças à amnésia da gênese, as dessecações da crítica e as dissertações acadêmicas ou as teses acadêmicas conferem um ar de eternidade (Bourdieu, 2006, p. 293).
\end{abstract}

Enredados nessas concepções, os estudos literários têm privilegiado manifestações literárias entendidas como "eruditas" em detrimento a poéticas populares como o cordel. É importante dizer que a dicotomia entre "popular" e "erudito" é "produto da revolução tecnológica e cultural da Renascença" (Scholes e Kellog, 1977, p. 12) e fundamenta o ideal segundo o qual apenas a escrita - com todos seus elementos estéticos, formais e ideológicos - é a responsável pela formação do universo literário, de modo que a oralidade é excluída como matriz literária constituinte da historiografia literária oficial. Como se pode perceber, o conceito do cordel como "popular" é uma construção engendrada por critérios históricos de diferenciação e hierarquia em que a oralidade é deslegitimada.

\footnotetext{
Esse discurso "scriptocêntrico" perpetua-se, até hoje em dia, em largos círculos dos estudos de Letras e não só nos da literatura escrita do cânone. Por inacreditável que possa parecer, muitos estudos das tradições orais e populares, ou das literaturas provindas de outras eras ou civilizações, baseiam-se, eles também, numa convicção scriptocêntrica subjacente: a de que os conceitos, noções, métodos e teorias do discurso acadêmico contemporâneo podem servir para analisar, interpretar e avaliar qualquer texto, de qualquer época, de qualquer camada social e qualquer região do mundo (Lemaire, 2007, p. 1).
}

Analisando o cordel, de bases orais, a partir de modelos e critérios de uma tradição literária escrita, a crítica literária reafirma a superioridade da literatura de base escrita, e não compreende os procedimentos próprios do texto de base oral. Contudo, a partir da década de 1970, estudiosos do Brasil e do exterior, seguindo os rastros do medievalista Paul Zumthor, dedicam-se ao estudo do cordel, e de outras manifestações artísticas, sob a perspectiva da oralidade. 
Ao resgatarem o estatuto de texto artístico, antes privilégio exclusivo da escritura, ressaltam as especificidades do texto oral, cuja literariedade acentua em plenitude a função da voz, imprimindo mais força à sua estrutura modal que, combinada à estrutura textual, explora aspectos corporais e físicos da comunicação (Alcoforado, 2007, p. 3).

Nesse sentido, o termo "popular" para designar o cordel é tomado como um indício de que essa poética faz parte da grande e rica tradição da poética das vozes ${ }^{35}$, da oralidade. O desenvolvimento da tecnologia da escrita, ao passo que significou um avanço no que se refere à manutenção de nossa história e cultura, entre outros fatores, também desencadeou uma série de disputas, especialmente no seio do que conhecemos como intelectualidade.

Como se erigiu a figura dos trovadores escamoteando-se o papel da oralidade e do povo, estabeleceu-se a hegemonia do homem de elite na configuração de todo o conhecimento e o que dele se deriva, como a cultura. A partir dessa concepção, os estudos tradicionais sobre o que hoje denominamos intelectual funda-se na crença de que o intelectual era o "único intérprete autorizado das coisas do mundo" (Mannheim, 1956, p. 102). Segundo Bastos e Rego (1999), desde Sócrates, seguindose estudiosos como Fichte, Benda e Sartre, por exemplo, o intelectual assume diferentes compromissos. Porém, em todos os contextos, torna-se o guardião e o porta-voz do conhecimento de toda a sociedade.

A partir da fixação da escrita como pedra inicial ao desenvolvimento de intelectuais, começou-se a se delinear o papel que este homem de cultura desempenharia na sociedade. E, como tudo que se desenvolveu em nossa sociedade, buscou-se preservar o esquema de nossa organização social "não só através de suas leis e instituições, mas também por uma distribuição apropriada das posições dominantes" (Mannheim, 1974, p. 102). Nesse sentido, muito se discutiu e se discute sobre o que é um intelectual. De um modo geral, uma atividade intelectual - que é o que caracteriza um intelectual - relaciona-se à produção, à reprodução e ao consumo de conhecimento, seja ele artístico, teórico, conceitual. Os clássicos estudos sobre essa categoria detêm-se à investigação dos papéis e funções que um intelectual deve exercer em uma sociedade, como podemos perceber nas ideias abaixo.

\footnotetext{
${ }^{35}$ A tomada dos estudos do cordel sob o prisma da oralidade é desenvolvida por Ria Lemaire em toda sua obra.
} 
1) Segundo Fichte, o intelectual deve difundir princípios fundadores da moralidade de modo que eduquem o gênero humano e o conduzam à comunidade (Bastos e Rego, 1999, p. 13).

2) De acordo com Ortega y Gasset, a intelectualidade deve despertar, educar e dirigir as massas. Uma minoria intelectual deve encarregar-se da educação das massas (Bastos e Rego, 1999, p. 22).

3) Sartre postula que cabe ao intelectual envolver-se com seu tempo e ser protagonista do processo civil (Bastos e Rego, 1999, p. 28).

A concepção subjacente a todos esses estudos é a responsável por uma série de dicotomias em que de um lado reside a atividade intelectual e de outro lado as demais atividades. A dicotomia entre cultos e incultos, ou seja, os que possuem e os que não possuem cultura, é uma das distinções que são fruto da legitimação de atividades intelectuais em detrimento, por exemplo, dos trabalhos manuais. A centralidade do intelectual na sociedade é axiomática. É ele o responsável pelo “caminhar da humanidade". Pode falar por todos, já que é o protagonista em meio a coadjuvantes que devem apenas acatar suas orientações. Assim se justificam as hierarquias em que apenas alguns podem falar. De acordo com Chauí (2006, p. 40),

$$
\begin{aligned}
& \text { os intelectuais tenderam a colocar-se como vanguarda esclarecida do } \\
& \text { proletariado, com a função de trazer a verdadeira consciência de classe às } \\
& \text { massas alienadas, desconsiderando a história dos movimentos operários e } \\
& \text { suas tradiççes anarquistas e socialistas, assim como as formas de ação e } \\
& \text { de organização dos trabalhadores brasileiros. }
\end{aligned}
$$

Apesar da pluralidade de perspectivas, locais de fala e visões de mundo, o que vale é a palavra da intelectualidade. Mesmo quando seus discursos se voltam ao que o povo produz, esse olhar é, no mínimo, duvidoso. Um exemplo disso é quando, nos finais do século XIX, há uma reação contra o ideal humanista vigente e os românticos vão à procura do que dominavam "fontes autênticas de cultura". Todavia, o que buscavam não era um diálogo, ou uma troca com a cultura do povo, mas, ao contrário: por meio de um olhar distante, "de fora" e autoritário, procuraram definir sua identidade nacional, adequando essa nova visão a seus ideais (Burke, 1989). Cabe ressaltar, no entanto, que a noção romântica de povo, que hoje é amplamente refutada, foi a responsável pela preocupação que mais do que nunca é central na agenda acadêmica: a existência, para além da cultura oficial e hegemônica, de outras culturas (Cirese, 1980, p. 74). 
A preocupação dos românticos, entretanto, ocorreu apenas no âmbito cultural e artístico. A primeira vez que a diversidade das culturas é tratada com estatuto acadêmico e científico foi quando os intelectuais, europeus em sua maioria, entraram em contato com sociedades não europeias, entendidas por eles como primitivas, e as olharam como culturas, apesar de ainda designá-las como primitivas. Apenas quando esses intelectuais olham para fora - para culturas "primitivas" - e depois voltam seu olhar para dentro, é que podem reconhecer que "os indivíduos outrora definidos de forma paternalistas, como camadas inferiores dos povos civilizados possuíam cultura” (Martin-Barbero, 2003, p. 43). Nesse contexto, nasceu a concepção de culturas subalternas e populares, tal qual compreendemos hoje, entendidas a partir de ideias hierárquicas acerca da diferença cultural.

\section{Suportes}

O cordel hoje é manchete.

Está na mídia virtual. Antes, ele foi oral. Passou pelo ofsete. Namora com a internet. Hoje, com tranquilidade, Mostra versatilidade, Dela tira seu proveito, Tem com ela laço estreito. Brinca, qual marionete.

Rosário Pinto

Em entrevista concedida a Gilmar de Carvalho (2002a), o poeta Patativa do Assaré, ao falar sobre sua gigantesca capacidade de memorização, adverte:

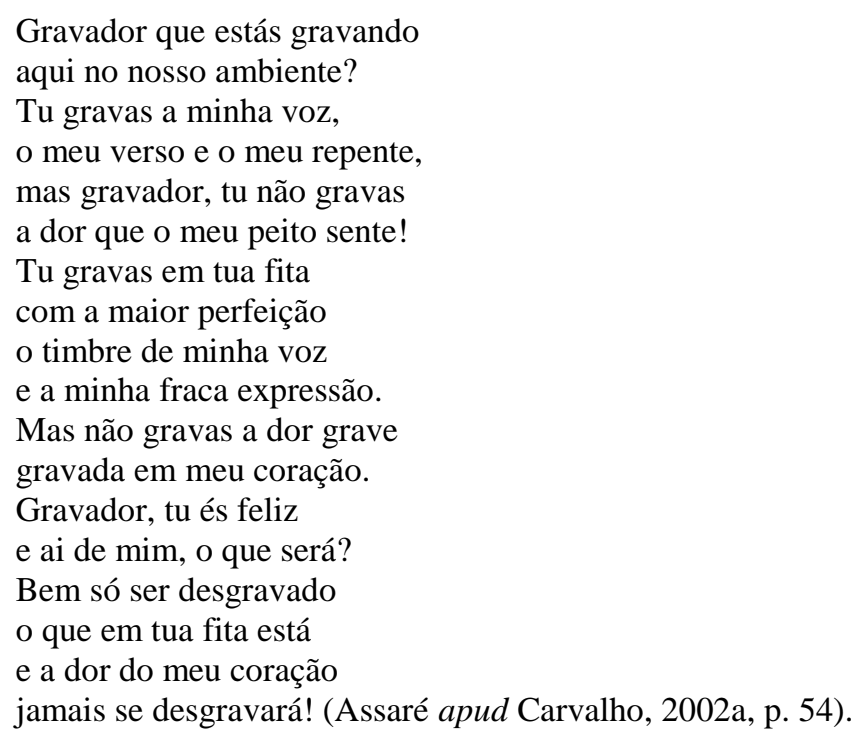


Em tom emotivo, mesmo dramático, o poeta revela o sentimento de que há algo - a dor - que o gravador não é capaz de registrar. Pesquisadoras e pesquisadores das poéticas das vozes, orais e populares deparam-se com o desafio de captar esse algo que o gravador não registra, que o folheto e o livro não captam. Pela facilidade de acesso que os folhetos e livros possibilitam - se comparado o acesso à voz do poeta - alguns pesquisadores estão cada vez mais distantes da realidade sobre a qual deveriam se debruçar. As vivas vozes estão (trans)(es)critas em folhetos, expostos em bancadas, ou em livros, exibidos em estantes. E é por meio dessas materialidades nas quais as vozes de poetas se fixam e se proliferam, que pesquisadores tiram suas conclusões e teses. Como afirma Paul Zumthor, a crítica literária ainda não dissocia da "ideia de poesia a de escritura" (Zumthor, 1993, p. 8).

A voz, cantada ou declamada, que tem o corpo como único suporte, não é considerada, na historiografia, como um meio de produção de obras literárias. Eric Havelock, argumentando a respeito da subalternidade da voz enquanto suporte de literatura e do preconceito epistemológico que a cultura da escritura instituiu, diz que

(nos festivais), os versos de uma sociedade oral descobrem os seus meios de "publicação", um termo exato para o processo, embora hoje se pense nela apenas em termos letrados, visto que a imprensa e a editora suplantam as situações orais do passado, ao ocasionarem uma circulação documentada entre leitores (Havelock, 1996, p. 96).

A criação da imprensa e de editoras, uma exigência da mudança dos tempos, mas também uma postulação de meios mais legitimados de publicação, apagou, até certo ponto, a existência de outras formas de expressão - os festivais como rituais de sociedades orais, por exemplo. Dessa forma, o surgimento de sistemas de editoração, como, no caso do Brasil, as gráficas de folhetos, ao mesmo tempo em que ampliaram as formas de publicação, criaram a divisão, nem sempre condizente com a realidade, de práticas poéticas orais e escritas (subjugando a primeira pela segunda). Esse fato pode ser visto na separação da cantoria e do folheto de cordel que, ao contrário do postulado por muitos estudiosos, são poéticas, muitas vezes, convergentes em suas práticas.

Essa convergência pode ser vista de diferentes formas - segundo Paul Zumthor (1993) -, na oralidade primária, em que a poesia ocorre somente a partir da voz, como com os cantadores, emboladores, entre outros; e na intersecção da oralidade primária e da secundária, como ocorre com os produtores de folhetos de cordel que somam ao seu repertório a cantoria e a embolada, sendo a voz e a escrita 
seus meios de produção ${ }^{36}$. E não só os produtores de cordel viveram a oralidade e a escritura como formas de acesso à essa poética, os ouvinteslleitores participaram desse processo, visto que o folheto, antes de ser lido (no sentido estrito do termo) individualmente e silenciosamente por seu público, foi declamado e contado a um público coletivo (Galvão, 2001). Houve um processo, uma transição (que é permanente) da oralidade à escritura, mediada, no Nordeste brasileiro, pelos folhetos de $\operatorname{cordel}^{37}$.

Como afirma Francisca Pereira dos Santos, os folhetos de cordel só se fixaram como um sistema produtivo de editoração e consumo no Nordeste brasileiro por três fatores:

\begin{abstract}
a) a existência, já amadurecida, de uma poética cantada; b) a presença das máquinas tipográficas no Nordeste, responsáveis pelo impulso das condições concretas para o estabelecimento de focos de produção de folhetos populares; e c) a apropriação, por parte dos poetas cantadores emergentes poetas de cordel -, dessas novas tecnologias de informação e comunicação (Santos, 2009, p. 19).
\end{abstract}

Os folhetos, dessa forma, emergem de um processo de evolução (da oralidade a escritura, nos termos de Eric Havelock), de apropriação (apoderamento pelos poetas das tecnologias, seja da escritura ou da tipografia) e de criação (uma nova poética é criada com bases da oralidade). Como defende Maurílio Antonio Dias de Sousa, a poesia oral e a poesia escrita, no campo estético, se entrecruzam, de modo que a segunda apresenta-se como continuidade da primeira. Já no campo mercadológico, há um distanciamento entre as duas práticas, fazendo com que a poesia de folhetos tenha suas regras próprias de produção, circulação e comercialização, diferentes das da poesia oral (Sousa, 2009).

\title{
Tipografias/folhetos
}

A poesia oral, que circulava apenas por meio da voz de seus autores, pôde ultrapassar os limites do corpo e mover-se, primeiramente por meio das folhas volantes e posteriormente dos folhetos. As folhas volantes consistiam em folhas

\footnotetext{
36 Atualmente, por haver maior alfabetização da população, entre outros fatores, o cordel é uma produção majoritariamente advinda da prática escrita, apesar de a oralidade se apresentar em muitos poetas como um procedimento de composição.

${ }^{37}$ É importante fazer uma ressalva a respeito das produções manuscritas, que estão entre a voz e o folheto. Em Cantadores, repentistas e poetas populares, José Alves Sobrinho ressalta a existência de uma grande produção manuscrita, em formato de folhas volantes, que eram afixadas em paredes de casas e espaços públicos em geral, que continham glosas.
} 
manuscritas com glosas, que eram afixadas nas paredes dos espaços públicos de grande circulação de pessoas. A glosa compunha-se, originalmente, a partir de um mote proposto pelo público ao poeta, a quem cabia desenvolvê-lo. Cada uma das estrofes da glosa deveria ser finalizada com um dos versos do referido mote.

\begin{abstract}
Este gênero de poesia teve tanta voga e uso intenso que veio a tornar-se o jornal do dia na capitania e mesmo nas cidades do interior. $\mathrm{O}$ poeta escrevia a glosa, digo a estrofe, com críticas, políticas ou sociais, e afixava nas paredes dos logradouros públicos. No dia seguinte o povo tomava conhecimento do ocorrido do dia anterior. Esse uso expandiu-se entre o povão de tal forma que não tardou muito surgirem poetas inspirados e destros que até faziam serões de glosas e ganhavam dinheiro com essa atividade (Sobrinho, 2003, p. 25).
\end{abstract}

O sucesso das folhas volantes ${ }^{38}$ foi acompanhado pela chegada da tipografia no Brasil (Melo, 2003, p. 58), que permitiu ao cordel ser um dos gêneros poéticos de maior importância no território brasileiro. A realização do folheto só foi possível a partir da chegada da tipografia no Brasil com a Família Real, que criou a Imprensa Régia em 1808. Antes disso, a publicação de documentos era censurada pela corte portuguesa, que trazia os impressos de Portugal (Alves Filho, 1999).

Dessa forma, logo os jornais da terra brasilis nasceram, e junto com eles suas tipografias e os primeiros folhetos. Sob encomenda dos autores de folhetos, as tipografias dos jornais, ou mesmo as destinadas à produção literária local, realizavam o serviço, como era o caso da Imprensa Industrial e da Livraria Francesa, que publicaram folhetos de Leandro Gomes de Barros e Francisco das Chagas Batista (Sodré, 2001). A chegada da tipografia trouxe outra possibilidade de divulgação da poesia produzida por esses poetas no Nordeste brasileiro.

\begin{abstract}
A folha de papel permitiu aos poetas da oralidade criar uma nova fonte de renda importante que recebeu, tanto na Europa dos inícios dos tempos modernos quanto no Brasil de finais do século XIX, o nome do próprio material: folheto, folha volante, pliego (folha dobrada) suelto, feuillet, vliegblad (folha que voa, em flamengo), broad-sheet em inglês (Lemaire, 2007, p. 4).
\end{abstract}

Os poetas, munidos de seus folhetos impressos ${ }^{39}$, partiam pelas cidades vendendo seu trabalho. Quando findados os exemplares, imprimiam-se outros nas tipografias locais. Todavia, com o rápido desenvolvimento da imprensa no Brasil, as máquinas tipográficas foram deixando os jornais e destinando-se a pequenos e

\footnotetext{
${ }^{38}$ As folhas volantes foram publicadas concomitantemente aos folhetos de cordel, conforme atestam as folhas volantes mimeografadas e datilografadas pela cordelista Sebastiana Gomes de Almeida Job em 1985 (Santos, 2011, p. 41).

${ }^{39}$ Os folhetos eram feitos em pequenas brochuras e com papel barato para depois serem vendidos a preços populares.
} 
autônomos editores que iniciaram a impressão exclusiva e regular de folhetos em suas próprias tipografias. É apenas entre 1909 e 1913 que as tipografias passam às mãos de editores e poetas populares, e em 1918 a atividade tipográfica do cordel passou a ser feita quase exclusivamente por elas (Terra, 1983, p. 24). Entre 1904 e 1930, existiam vinte tipografias destinadas à feitura do folheto de cordel no Brasil (Terra, 1983), conforme tabela a seguir.

Relação de tipografias e sua respectiva localização entre 1904 e 1930 no Brasil

\section{Tipografia}

Imprensa Industrial

Tipografia Miranda

Tipografia Moderna

Tipografia do Jornal do Recife

Tipografia da Livraria francesa

Tipografia Perseverança

Tipografia Mendes

Tipografia Chaves

Tipografia de J. Martins de Athayde

Tipografia da Livraria Gonçalves Pena

Tipografia Pernambucana

Tipografia Popular Editora

Tipografia de Pedro Batista

Tipografia Minerva de Assis Bezerra

Tipografia Fernandes

Tipografia Lima

Tipografia d' O Progresso

Tipografia Editora Guajarina

Tipografia Antunes

Tipografia Papelaria Pacheco

\author{
Localização \\ Recife \\ Recife \\ Recife \\ Recife \\ Recife \\ Recife \\ Recife \\ Recife \\ Recife \\ Paraíba \\ Paraíba \\ Paraíba \\ Paraíba \\ Fortaleza \\ Maceió \\ Maceió \\ Currais Novos, Rio Grande do Norte \\ Belém, Pará \\ Rio de Janeiro \\ Rio de Janeiro
}

Registra-se, ainda, que, entre as décadas de 1940 e 1960, surgiram no Brasil as seguintes tipografias: Folhetaria Santa Luzia, Tipografia São Francisco ${ }^{40}$, Tipografia de Odílio Figueiredo, Tipografia da Livraria Ramiro,Tipografia D' O Juazeiro, Tipografia Lima, Tipografia e Folhetaria Casa dos Horóscopos, Tipografia Graça Fátima (Tipografia São Joaquim), Tipografia Luzeiro do Norte (Editora Luzeiro), Editora Prelúdio, Tipografia Santos (A Estrela da Poesia) e Editora Baiana (Melo, 2003).

Em 1998, é lançado o projeto SESCordel Novos Talentos, do Serviço Social do Comércio (SESC), com a publicação do folheto Alestey Crowley na terra do Padre Santo, de Antonio Celestino. Esse projeto reativou a feitura de folhetos pela importante tipografia Lira Nordestina e lançou diversos novos cordelistas e gravadores, principalmente mulheres cordelistas e gravadoras, o que foi realizado

${ }^{40}$ De 1939 denominada de Tipografia e Folhetaria Silva, passando a chamar-se, em 1980, de Lira Nordestina (Melo, 2003). 
com pioneirismo, motivo pelo qual foi agraciado, em 2001, com o prêmio Rodrigo Melo Franco, do Instituto do Patrimônio Histórico e Artístico Nacional (IPHAN), na categoria "divulgação".

Hoje, tem-se notícia que está em funcionamento a Tipografia Lira Nordestina, sediada na Universidade Regional do Cariri desde 1988, e a Tipografia da Academia dos Cordelistas do Crato. Também são diversas as editoras especializadas na publicação de cordel, entre as quais se pode citar: Academia Brasileira de Literatura de Cordel (ABLC), no Rio de Janeiro, cujo presidente é Gonçalo Ferreira; Luzeiro, em São Paulo; Coqueiro, de Ana Ferraz, em Recife; Tupynanquim, em Fortaleza, de Klévissonn Viana; Queima-Bucha, no Rio Grande do Norte; Chico Editora, em Natal; J. Borges, em Pernambuco.

A produção de folhetos nessas tipografias seguia, em sua maioria, um processo comum. Primeiramente, realizava-se a revisão dos originais, quase todos manuscritos, por meio da correção ortográfica e métrica.

\footnotetext{
É importante destacar que a maior parte dos poetas de bancada buscavam, e ainda buscam, a excelência no que se refere ao uso da língua portuguesa e quanto às regras de metrificação. Na poesia de bancada não há lugar para o improviso (Melo, 2003, p. 83-84).
}

$\mathrm{Na}$ maioria das tipografias, quem revisava os originais era o proprietário, autor, editor, tipógrafo e administrador. Após a revisão, há o "cata-cata", processo pelo qual o tipógrafo seleciona os tipos ${ }^{41}$ para preparação das matrizes. Para isso, se requeria do tipógrafo o conhecimento do alfabeto. Assim, os tipos eram dispostos no interior da matriz que era levada para a máquina de impressão, nela os tipos eram cobertos de tinta e impressos em papel. As máquinas mais antigas funcionavam manualmente. Após impresso, o folheto passava pelo processo de acabamento em que as folhas eram cortadas, ou por tesoura ou por cortador de papel, e, por fim, dobradas (Sousa, 2009).

Apoderando-se dessa tecnologia de impressão tipográfica, os poetas ampliaram suas fontes de renda e suas formas de manifestação artística, que agora poderiam tanto ser cantadas e declamadas como vendidas impressas. Os poetas do mundo do folheto incluíram-se no processo de desenvolvimento das tecnologias da

41 Tipos são peças de chumbo saliente sobre a forma de uma letra do alfabeto. São de variados tamanhos e estilos. No Brasil, o maior fornecedor de tipos era o Funtimod, de Recife. 
comunicação e com isso erigiram um sistema editorial de folhetos com produção, divulgação e distribuição próprios, como fizeram Leandro Gomes de Barros (Terra, s.d.), Francisco das Chagas Batista (Batista, 1997), Francisco Rodrigues Lopes (Salles, 1971), José Bernardo da Silva (Melo, 2003), entre outros.

Contradizendo Adorno e todos os fatalistas frankfurtianos que postulam que "o terreno no qual a técnica conquista seu poder sobre a sociedade é o poder que os economicamente mais fortes exercem sobre a sociedade", de modo que "a racionalidade técnica é a racionalidade da própria dominação" (Adorno, 1985, p. 114), o apoderamento dessas tecnologias da comunicação, como a tipografia, significa que os instrumentos utilizados pelos poderes e pelas elites intelectuais e econômicas para firmarem sua dominação podem ser também utilizados pelos poetas populares para manifestarem sua existência e afirmarem seus projetos e protestos. Em outras palavras, o que é aparentemente dependência e dominação pode tornar-se resistência, refuncionalização e redefinição (Martin-Barbero, 2003).

Além dessas conquistas, como a ampliação das formas de divulgação e de renda de poetas por meio do folheto de cordel, ele também foi responsável pela fixação de

\footnotetext{
normas e procedimentos até então estranhos à oralidade (...); passou a propiciar, no suporte, estudos que envolvem determinados aspectos literários, como a análise tipológica de gênero e as comparações estilísticas. (...); e permitiu também a formação de coleções, acervos de obras impressas no passado (Sousa, 2009, p. 38-39).
}

O movimento da oralidade à escrita, sendo permeado pelo folheto, é, inegavelmente, uma grande abertura de portas, pois, como afirma Martin-Barbero, “dizer sim ou não às tecnologias é dizer sim ou não ao desenvolvimento" (MartinBarbero, 2003, p. 265). Contudo, a sobreposição do folheto à oralidade, apesar de ele cumprir a tarefa de presentificar essa poética por meio de tempos e espaços diversos e concomitantes, também originou, em quem o estudava, uma série de limites à sua compreensão. O desaparecimento da dimensão da oralidade nos estudos do cordel deu margem ao entendimento dessa poética como marginal, algo menor - porque o folheto era (e muitas vezes ainda é) analisado com as lentes de uma cultura escrita ${ }^{42}$.

42 Vale ressaltar que importantes trabalhos foram realizados por meio da utilização de uma teoria essencialmente scriptocentrica, como o da pesquisadora Vilma Mota Quintela, denominado $O$ cordel no fogo cruzado da cultura (2005), em que a teoria de sistema literário construída por Antonio Candido é transposta ao estudo do cordel. 
Somados à marginalização ${ }^{43}$ da poética do cordel nos estudos literários, tem-se a marginalização de seus produtores, de seu suporte e de seu público.

A marginalização de seus produtores deve-se muito ao mito do poeta popular como um homem pobre, analfabeto ou semiescolarizado, que escreve versos simples $^{44}$, em um suporte material simples, destinados a gente simples. A simplicidade, como o avesso da complexidade - característica da literatura hegemônica -, é, de um modo geral, a palavra e o pensamento que traduz a posição de marginalização do cordel no campo literário. A valoração, na maioria das vezes pejorativa ou condescendente, atribuída à materialidade (o suporte folheto, entendido como simples), à poética (o cordel, como uma poética da oralidade, entendida como simples), aos autores (poetas simples) e ao público (gente simples) formam a concepção que a crítica literária hegemônica tem sobre o cordel.

As generalizações, e muitas vezes abstrações, sobre essa poética ocorrem não só por conta da distância geográfica entre poetas e pesquisadores, mas, e creio que principalmente, pela utilização de bases críticas e teóricas construídas no passado e apenas repetidas reiteradas vezes sem se olhar para a realidade de produção dessa poética. Como afirma Ana Maria Galvão a respeito de algumas pesquisas sobre cordel, "um estudo repete o outro, complexificando e aprofundando pouco as informações exaustivamente repetidas" (Galvão, 2001, p. 21). E assim se formou a história e a historiografia do cordel, dentro dos gabinetes.

\footnotetext{
43 Arnaldo Saraiva, em seu livro Literatura marginal-izada (1975), é quem primeiro define o cordel como uma literatura marginal-izada, ou seja, posta à margem por um campo e um sistema literários que a desprezam e que apenas repetem a mesma história literária dos cânones oficiais.

${ }^{44}$ A pesquisadora Jerusa Pires Ferreira, ao propor aos seus alunos do curso de Comunicação Popular da USP que estudassem editoras populares do Brás, em São Paulo, defrontou-se com a seguinte conclusão de um dos estudantes, "Os produtos são simples para pessoas simples" (Ferreira, 1997, p. 104).
} 


\section{Parques gráficos/livros}

Depois os meus colegas viram aquilo (publicação de Inspiração nordestina, em 1956) também começaram a fazer livro, viu? Livreto, livro, viu? Parece que eles achavam que o cantador de viola não podia fazer... publicar assim um livro e tal.

Patativa do Assaré

Patativa do Assaré (1909-2002), um dos mais conhecidos e aclamados poetas do universo das poéticas das vozes, foi reconhecido desde muito cedo por um grande público, composto por gente de cá e de lá - pobres e ricos, alfabetizados e analfabetos, intelectuais da academia e intelectuais do povo -, metaforizando as palavras do próprio poeta. Sua primeira obra publicada, Inspiração nordestina, de 1956, teve, em sua primeira edição, o prefácio escrito pelo latinista José Arraes de Alencar que, em visita à cidade do Crato, no Cariri cearense, conheceu Patativa. O prefaciador também foi o responsável por apresentar a obra de Patativa à editora Borsoi. É ele também que diz, no prefácio, que entrega "uma preciosa obra que iria fatalmente desaparecer com seu autor”. Nessa declaração, pode-se perceber sua perspectiva sobre essa poética, que, para permanecer, precisaria de um meio de preservação, que não poderia ser conseguido pelo próprio poeta.

A publicação da obra de Patativa foi marcada pela mediação de intelectuais e de suas instituições. E, como um dos símbolos de mediação material e simbólica da presença da intelectualidade, o suporte livro se fez presente. Mantedor da palavra expressa, com toda sua força legitimadora, o livro, com status de produto erudito e portador de prestígio e distinção cultural, para os poetas da oralidade significou, muitas vezes, uma forma de legitimação e valorização de sua obra. Nos termos de Pierre Bourdieu, esse suporte atribui ao que carrega uma série de valores: capital cultural (conhecimentos legítimos), social (representa relações sociais valorizadas) e simbólico (símbolo de prestígio social) (Bourdieu, 2006).

Apoderando-se de todos esses capitais, os poetas que publicaram suas obras em editoras hegemônicas tiveram outro tipo de inserção nesse campo poético, uma vez que o folheto - suporte por excelência do cordel - não chegou a ter estatuto cultural de obra literária pelo sistema editorial; e pelo campo literário brasileiro. Como ironicamente afirma Martin-Barbero, “o folheto não fica de pé, não dispõe de 
uma bela encadernação, sua materialidade não poderá ser exibida como expoente cultural" (Martin-Barbero, 2003, p. 188). Por esse e outros motivos, não vemos folhetos em livrarias. Eles estão em ruas, feiras, bancas, hoje na internet. Possuem outros meios de circulação e divulgação.

Dentro da moldura que são os livros, Patativa inscreveu sua obra nas estantes. Refutando-se a ser conhecido como poeta de bancada, teve, em toda sua vida, poucos cordéis publicados. É clara a distinção feita pelo poeta de quem publica livros e de quem publica cordéis em seus folhetos. Ele publica estrategicamente sob o suporte livro. Mas, vale ressaltar que, imbuída na legitimação e na valorização positivas que o livro concede ao que carrega, ele significa, ao mesmo tempo, o acesso ao conhecimento e a sua interdição. Barreiras econômicas e sociais, que andam juntas, muitas vezes, dão origem a esses dois movimentos.

Ao mesmo tempo em que o folheto possibilita o consumo e a publicação de públicos e produtores de várias classes econômicas e sociais, o livro os restringe a uma pequena parcela, uma vez que mantém, e mesmo reforça, alguma segregação cultural. Se o folheto de cordel não é um suporte que é dado ao povo, mas que o próprio povo se dá, o livro é um suporte feito por meios hegemônicos de produção e divulgação para quem tem acesso a eles.

Dentro ou fora da moldura, o cordel nos mostra que o empoderamento dos poetas pela feitura de seus folhetos em tipografias e (ou) pela publicação de sua poética em editoras (como acontece com Patativa) são diferentes estratégias de inserção. Todavia, não se pode perder de vista as implicações que os diversos suportes desencadeiam.

\footnotetext{
Os textos não existem fora dos suportes materiais (sejam eles quais forem) de que são veículos. Contra a abstração dos textos, é preciso lembrar que as formas que permitem sua leitura, sua audição ou sua visão participam profundamente da construção de seus significados (Chartier, 2002, p. 61-62).
}

Os diferentes suportes, no caso o folheto e o livro, constituem tanto o objeto quanto o que ele tem dentro de si como conteúdo. Estar escrito em um folheto ou em um livro dá ao cordel significados diferentes: enquanto o livro atrela-se a uma estética erudita, socialmente valorada e legítima, o folheto, por sua vez, parece possuir uma representação negativa, partindo-se do ponto de vista hegemônico. A 
“imagem social” (Bourdieu, 2007, p.24), marca uma distinção entre o cordel sob o suporte livro e sob o suporte folheto.

Atualmente, algumas editoras mantêm projetos editoriais voltados à publicação de cordel em forma de livro, como a editora Vozes, em Petrópolis, no Rio de Janeiro, e as editoras Nova Alexandria e Hedra, de São Paulo. A editora Hedra, em 2000, lançou uma das mais importantes publicações da atualidade sobre o cordel: a Coleção Biblioteca de Cordel, idealizada e dirigida pelo professor e pesquisador holandês Joseph Luyten. O projeto editorial previa 50 livros, sendo cada um destes dedicado a um poeta e prefaciado por um estudioso da área. Até o momento, dos 50 livros previstos, foram lançados apenas 22 , sendo as últimas publicações do ano de 2007. A Coleção dá prosseguimento a uma série de pressupostos de julgamento do cordel e consiste em mais uma forma de controle da poética das vozes por um segmento do mercado editorial, conforme será trabalhado mais adiante.

\title{
Internet/cordel digital ou cibercordel
}

\author{
A internet chegou \\ Como grande aliada \\ Pro cordel abriu estrada, \\ E o cordelista gostou \\ No virtual apostou \\ E com tecnologia \\ Espalhou sua poesia \\ Por este mundo global \\ Onde o cordel tem aval \\ Nesta metodologia. \\ Dalinha Catunda
}

Ao surgimento de um novo suporte material de textos, suscitam-se mudanças nas formas de leitura, autoria, nos valores do texto, em sua demanda, entre outros. A internet é um desses fatores de transformação, sendo apontada como responsável por uma "revolução virtual” (Chartier, 1999), já que impulsionou uma metamorfose tanto na técnica de produção (forma) quanto na de reprodução de textos (suporte).

O cordel, assim como diversas outras produções artísticas, culturais e literárias, está presente na internet e passando por sua "era revolucionária".

Nenhuma das transformações chega a radicalidade e envergadura da última, a dos finais dos anos 90: a internetização do cordel. Pela primeira vez na sua evolução, o cordel abandona o papel e entra na onda virtual da tela do computador. Começou a era revolucionária do cordel eletrônico, cibernético (Gadzekpo, 2004, p. 3). 
Assim, tem-se outra forma de acesso, preservação, armazenamento e disseminação do cordel, seja pela digitalização dos folhetos ou pela criação de cordéis na própria mídia digital, também denominados de cordéis eletrônicos ou cibercordéis (Gaudêncio, 2014, p. 57), em alusão aos conceitos de cibercultura e ciberespaço, de Pierre Lévy (1999 e 2007).

O cordel, enquanto gênero literário, encontrou terreno propício ao seu desenvolvimento, uma vez que a internet, principalmente o blogue, possibilita a publicação frequente, a autopublicação, o tratamento de temas cotidianos, do momento, em tom coloquial, entre outros elementos. A imensa circulação de textos na web por um ínfimo custo também impacta no crescimento do número de sites, portais, redes sociais e blogues sobre o cordel.

Em mapeamento realizado entre julho e agosto de 2013, Sale Mário Gaudêncio (2014) registrou 86 páginas de cordelistas e 34 páginas de instituições e editoras voltadas ao assunto. Esse total abrange as páginas que se destinam à formação de acervo histórico - folhetos impressos são digitalizados - e às voltados à autopublicação - criação de cordéis mediante recursos eletrônicos.

O blogue consiste na ferramenta mais empregada por cordelistas, pela facilidade técnica de atualização da página e pelos poucos recursos financeiros necessários à sua manutenção. Além disso, associado às redes sociais, é espaço que permite, ao mesmo tempo, a produção, divulgação e comercialização da obra, caso seja o objetivo da(o) cordelista. Em última palavra, o espaço virtual dos blogues tem dado visibilidade a acervos históricos de cordéis, tem fortalecido e complementado o folheto impresso, além de se apresentar como o primeiro suporte à autopublicação e uma plataforma de inserção em círculos de cordel.

Para Roger Chartier (1999, p. 71), “a obra não é jamais a mesma quando inscrita em formas distintas, ela carrega a cada vez, um outro significado". Contudo, na composição de poéticas populares como o cordel, nem sempre a mudança de suporte implica mudança de métodos composicionais, conforme atestam diversos cordelistas, entre os quais se incluem Maria das Neves Pimentel, Patativa do Assaré, Esmeralda Batista e Bastinha, que compõem suas obras sem o emprego da escrita. Ou seja, são elaboradas primeiramente na mente e, só depois de finalizadas, são passadas ao papel ou às telas de computador.

Patativa do Assaré, um dos poetas populares que mais publicou sua obra em livros, compunha seus versos na mente. Em entrevista dada a Gilmar de Carvalho, o 
poeta do Assaré declara: "muita gente não sabe como é que eu componho os meus poemas. Não é escrevendo! É... faço a primeira estrofe, deixo retida na memória. A segunda do mesmo jeito, a terceira e assim por diante" (Carvalho, 2002a, p. 17-18). Só depois de os poemas prontos, na mente, é que são transcritos. Patativa tinha na "cachola" todos os seus poemas, que, na maioria das vezes, só eram transcritos por outras pessoas. Em relação ao seu livro Inspiração Nordestina, Patativa declara: "foi escrito de mim para o doutor Moacir Mota, era eu dizendo e ele batendo à máquina, lá no Crato. Eu tinha tudo na mente !!!"” (Feitosa, 2003, p. 39).

Há também cordelistas que usam tanto da oralidade como da escrita para comporem seus versos, como é o caso da cordelista cearense Sebastiana Gomes de Almeida Job, mais conhecida como Bastinha, que atesta que produz seus poemas primeiramente na cabeça e só depois de prontos os passa, ela mesma, ao papel.

Já a poética de Salete Maria da Silva é marca do encontro de diferentes suportes: manuscrito, folheto, mídia digital; utilizando-se, ainda das redes sociais e sítios de compartilhamento de vídeos para divulgar sua poética ${ }^{45}$. Diversos poetas também realizam pelejas virtuais ${ }^{46}$, que consistem em "disputas poéticas via e-mail ou bate-papo na rede das redes, publicando, a seguir, estes embates em verso" (Amorim, 2007, p. 7), sendo esta mais uma apropriação da internet por poetas das vozes.

\section{Discursos}

O cordel, conhecido majoritariamente na versão de folhetos feitos em tipografias em papel jornal, vem sendo publicado de novas formas, inaugurando outra realidade de produção e divulgação. Em páginas de livros, são crescentes os projetos editoriais que se destinam à publicação dessa poética, assim como a internet vem sendo amplamente empregada para a publicação dessa poética, que se move da voz ao papel manuscrito, aos folhetos e às telas de computadores, coexistindo hoje em todos esses espaços.

No caso do transporte do cordel dos folhetos para os livros, como acontece na Coleção Biblioteca de Cordel, há uma tentativa de introdução do cordel no mercado

\footnotetext{
45 Salete Maria da Silva divulga sua obra no blog Cordelirando, que tem página homônima nas redes sociais. A cantora Socorro Lira, em vídeo disponível no Youtube, declama o cordel Beata Maria de Araújo, de Salete Maria.

${ }^{46}$ A respeito das pelejas virtuais, ver Amorin, 2007.
} 
editorial brasileiro, nos estudos acadêmicos e o empoderamento dos poetas por novas formas de publicação, o que ocorre por meio de várias estratégias editoriais, como a utilização de introduções e prefácios escritos por intelectuais que apresentam e legitimam o texto. É importante observar que, apesar da entrada do cordel no mercado editorial hegemônico, as pequenas tipografias funcionam e mantêm viva a produção de folhetos.

No caso do uso da Internet, como acontece com a obra da cordelista Salete Maria da Silva, percebe-se uma reterritorialização do cordel, que ganha novos públicos e mesmo se torna acessível aos diversos públicos. Essa cordelista posicionase como tal e insere-se em uma longa história de produção cordelística, que, como a história da literatura brasileira hegemônica, tem seus valores, cânones e paradigmas.

O discurso historiográfico responsável pela construção do cânone do cordel brasileiro foi erigido, como aponta Francisca Pereira dos Santos (2009), por meio dos estudos realizados no âmbito da Fundação Casa de Rui Barbosa, do trabalho desenvolvido pelo francês Raymond Cantel e das pesquisas feitas por Átila Almeida e José Alves Sobrinho, que originaram o Dicionário bio-biográfico de repentistas e poetas de bancada. A estudiosa Candace Slater (1984, p, 48) também aponta a publicação do Catálogo pela FCRB e a presença de Cantel no Brasil como fundamentais à fixação de determinado pensamento crítico. Acrescento a esse rol, a Coleção Biblioteca de Cordel da editora Hedra, que atesta e dá prosseguimento aos discursos que a antecedem. A despeito de importantes estudos sobre o cordel que contradizem as publicações elencadas, o discurso por elas articulado é preponderante nos estudos dessa área, sendo a principal referência histórica, teórica e crítica.

\begin{abstract}
Embora se reconheça a importância dessas contribuições - chamadas no discurso de seus promotores como de revitalização, resgate e promoção do folheto para sua inclusão no âmbito dos estudos críticos -, estas investigações representaram escolhas teóricas e metodológicas que, tendo em vista os novos processos emergentes que ocorrem no campo dessa área, contemporaneamente, necessitam ser revisadas para oportunizar a inserção de outras tradições culturais que visivelmente foram deixadas de lado (Santos, 2009, p. 61-62).
\end{abstract}

Mediante os parâmetros teóricos e metodológicos erguidos por esses discursos, passou-se a postular o conceito e os limites da "literatura de cordel", também seus autores, seus meios legítimos de publicação, entre outros aspectos. Essas iniciativas de preservação e valorização do cordel foram vias de mão dupla, uma vez que, na demarcação de fronteiras, se deixou muito do lado de fora, como os cordéis de autoria de mulheres. 
Construir uma narrativa histórica e querer que ela seja definitiva e perpétua é o mote seguido pelos cânones oficiais, sejam eles da História (com "h" maiúsculo e no singular), ou da Literatura (com sua inicial também maiúscula e o mesmo e insistente singular). Construídos, em sua maioria, por intelectuais e suas instituições, os cânones historiográficos carregam em sua constituição uma "vontade de verdade e poder" (Foucault, 2005), que se estabelece por meio de discursos sobre o que é (e deve ser) parte constitutiva de uma determinada historiografia.

É importante ressaltar que, antes desses movimentos de institucionalização do cordel, em meados de 1960, a legitimação de poetas era feita por vias exteriores ao mundo da intelectualidade erudita e acadêmica, ocorria por meio do reconhecimento dos poetas pelos seus pares.

\begin{abstract}
O reconhecimento do poeta (poeta de bancada), como exercício profissional, inicia-se na publicação do folheto e legitima-se no reconhecimento por parte de um poeta reconhecido. Primeiro, o poeta escreve e publica os seus folhetos. E essa nova posição se fortalecerá se vier coroada de reedições. Era a escrita do folheto que traçava a linha divisória de uma a outra função. Em segundo lugar, como a escrita do folheto corresponde a um rito de passagem, é por ela que o poeta será reconhecido pelo outro. Mediante a confirmação de um poeta já gabaritado, a categoria do novo poeta é confirmada e ele, enfim, pode vir a ser canonizado, em gesto de reconhecimento que serão espontaneamente repassados a todos os níveis envolvidos (Sousa, 2009, p. 168).
\end{abstract}

Nesse momento, o campo do cordel e seu sistema eram independentes da crítica literária hegemônica e da universidade de uma forma geral - o que transbordava para o distanciamento do folheto do ensino escolar e para a formação de acervos - que se encarregaram, a partir das iniciativas de formação e sedimentação de um cânone, de selecionar, avaliar e legitimar determinados cordéis e autores em detrimento de outros.

A centralidade da voz de uma intelectualidade dentro de diversas sociedades, neste caso a brasileira, toma a palavra para si, sendo "a" responsável pelos discursos oficiais e legítimos. E isso é o que acontece no contexto do cordel: o poder de fixação de sua historiografia (não que a construída pelos poetas também não seja, em certos pontos, excludente) passa às mãos das instituições que formulam discursos de autoridade sobre essa poética.

Vale dizer, ainda, que o resgate, a visibilização e a promoção do cordel por esses estudos foram fundamentais para o fortalecimento dos trabalhos sobre o cordel. As pesquisas realizadas nesse período inserem-se em um contexto de emergência de 
estudos da cultura popular no Brasil, suscitado por trabalhos como $A$ formação $d a$ classe operária inglesa, do historiador inglês Edward Palmer Thompson (1963); A cultura popular na Idade Média e no Renascimento: o contexto de François Rabelais, do teórico da literatura russo Mikhil Bakthin (1965); e Os intelectuais e a organização da cultura e Literatura e vida nacional, de Antônio Gramsci, ambos publicados em 1968. Esse momento foi decisivo para o estabelecimento de uma tradição de estudos de poéticas populares e orais, ainda que tenham sido estabelecidos paradigmas que hoje estão sendo questionados e superados.

\section{Fundação Casa de Rui Barbosa}

A Fundação Casa de Rui Barbosa (FCRB), localizada no Rio de Janeiro e composta por um Centro de Pesquisa, um Centro de Estudos Históricos, um Centro de Documentação e um Arquivo Museu de Literatura, foi fundada em 1928, e consiste em uma instituição vinculada ao Ministério da Cultura, que tem por objetivo "promover a preservação e a pesquisa da memória e da produção literária e humanística, bem como congregar iniciativas de reflexão e debate acerca da cultura brasileira" ${ }^{\prime 4}$.

A fim de consolidar essa missão, a FCRB, a partir da década de 1960, deu início a um projeto editorial voltado à publicação de estudos sobre o cordel brasileiro, denominado Literatura popular em verso, finalizado em 1992, com a publicação de $O$ ciclo épico dos cangaceiros na poesia popular do Nordeste, do estudioso alemão Donald Daus.

É nesse projeto que o folheto passa a ser amplamente designado como "literatura popular em verso" ou como uma "literatura de cordel". O projeto foi coordenado por Thiers Martins Moreira e contou com os estudiosos M. Cavalcanti Proença, Orígenes Lessa, Manuel Diegues Jr. e Antonio Houaiss, além da participação de Sebastião Nunes Batista (filho do poeta e editor Francisco das Chagas Batista). O objetivo desse projeto era desenvolver

um conjunto de medidas para a promoção da literatura de cordel, que compreendem desde levantamentos bibliográficos e organização de coleções, à preservação de documentos preciosos na iminência de se

${ }^{47}$ Disponível em: www.casaruibarbosa.gov.br/template_01/default.asp?VID_Secao=10. Acesso em: maio, 2009. 
perderem e publicação de uma extensa bibliografia, composta por catálogos, antologias e estudos especializados ${ }^{48}$.

O projeto foi iniciado com a publicação ${ }^{49}$ de um Catálogo (1961), seguido de uma Antologia (1964) e, posteriormente, de diversos artigos reunidos em Estudos (1973); e contou com a colaboração de importantes intelectuais, a saber: Thiers Martins Moreira, Manuel Cavalcanti Proença, Orígenes Lessa, Manuel Diégues Júnior e Antônio Houaiss. Os poetas Rodolfo Coelho Cavalcante e Sebastião Nunes Batista também integraram esses estudos e serviram, muitas vezes, de informantes com conhecimento previlegiado sobre o meio.

As concepções históricas, teóricas e críticas que fundamentaram essas publicações se ligam aos trabalhos desenvolvidos por Sílvio Romero e Câmara Cascudo. Além disso, a poética do cordel é pensada com base em categorias de análise da literatura erudita, canônica e escrita. É importante lembrar que no período em que foram elaborados esses estudos vigorava em nosso país a ditadura militar, cuja ideologia também está presente nos estudos da FCRB.

Nessas publicações, e subjacente aos objetivos evidenciados explicitamente pela FCRB, o norte foi o cordel enquanto uma narrativa da nação, como defende Santos (2009). Dessa forma, a historiografia construída obedeceu aos mesmos preceitos de construção traçados para a historiografia literária brasileira hegemônica. A preponderância da nação na base desses cânones, seja da literatura hegemônica seja do cordel, passa a estabelecer parâmetros teóricos, o conceito e os limites dessas manifestações artísticas, bem como seus autores, seus meios legítimos de publicação, entre outros tantos aspectos.

A despeito de o projeto Literatura popular em verso buscar a visibilização da arte popular brasileira e a sua inserção no círculo de estudos acadêmicos - objetivos importantes para o fortalecimento dos estudos do cordel -, ele foi responsável por fixar uma série de concepções que entendiam o cordel como uma poética estática, imóvel, não passível de mudanças. A ligação do cordel com as noções de autenticidade, nacionalismo, patrimônio nacional e ingenuidade, repetida muitas

\footnotetext{
${ }^{48}$ Disponível em: http://www.casaruibarbosa.gov.br/template_01/default.asp?VID_Secao=99. Acesso em: maio, 2009.

49 As referências as obras publicadas pela Fundação Casa de Rui Barbosa constam nas referências bibliográficas.
} 
vezes por diversos estudiosos da área como verdade inquestionável, é sedimentada por esses estudos, que se assentam nessas concepções.

A atribuição de origem europeia e espanhola ao cordel e o esquecimento de sua origem também africana, por exemplo, são discursos repetidos, sem falar da ausência de autoria de indígenas, negros e mulheres.

O genocídio indígena que se deu em território brasileiro é repetido na historiografia do cordel. Negros e negras aparecem apenas enquanto temática, a exemplo de $O$ negro na literatura de cordel (Santos, 1989), livro publicado na ocasião da comemoração do centenário da abolição da escravatura, em que negros e negras avultam apenas como personagens representativos da realidade brasileira, e não como autores. Houve, contudo, diversos autores negros, como Inácio da Catigueira, Manoel Caetano, José Pretinho, Romano Elias da Paz, Manoel Regino, Manoel Preto Limão (Coutinho Filho, 1972 e Carvalho, 1967) e, no mínimo, uma autora negra, a poeta e cantadora Chica Barrosa (Carvalho, 1967); contudo, a historiografia caracteriza-se pelo esquecimento das mulheres, assim como de indígenas e negros.

Os métodos, parâmetros e valores empregados na análise dos cordéis são tomados de estudos teóricos desenvolvidos no âmbito da literatura de bases escritas, desconsiderando-se a filiação com a oralidade da poética do cordel. Isso desencadeou uma série de julgamentos preconceituosos e depreciativos, uma vez que os atributos de poéticas populares eram avaliados como menores aos olhos de valores da escrita.

\section{Dicionário bio-bibliográfico de repentistas e poetas de bancada}

Assim como a FCRB tentou estabelecer uma historiografia e um cânone do cordel, o poeta, repentista e pesquisador José Alves Sobrinho, sob a coordenação do professor Átila Almeida, da Universidade Federal da Paraíba, o fez com as pesquisas que culminaram com a publicação do Dicionário bio-bibliográfico de repentistas $e$ poetas de bancada, e também com outros estudos ${ }^{50}$. O Dicionário foi publicado pela Universidade Federal da Paraíba, que mantinha parceria, desde 1976, com a FCRB. Com o objetivo de resgatar e reabilitar essas poéticas da oralidade, José Alves Sobrinho deu visibilidade a muitos repentistas e poetas apagados, até então, da

\footnotetext{
${ }^{50}$ Ver: Almeida, Sobrinho (1981); Sobrinho (1975); (1982); (1994) e (2003).
} 
historiografia. Como homem "de dentro" dessas poéticas, sendo um dos mais conhecidos cantadores de repente do estado da Paraíba, Sobrinho coletou no mundo e nos livros sobre cordel mais de três mil folhetos.

A presença de Sobrinho, e a sua relação com o professor Átila Almeida, é outra questão interessante na construção desse cânone. O ganho maior do Dicionário é, com certeza, a pesquisa realizada por Sobrinho, com todo seu conhecimento acerca do universo da poética das vozes em território nordestino. O próprio professor da Universidade da Paraíba reconhece do poeta, que, em suas palavras, fazia "ombro pr'eu trepar e lá de cima escrever em parceria com ele um dicionário" (Almeida apud Sobrinho, 1982).

Joseilda de Sousa Diniz, uma das mais importantes pesquisadoras da obra de José Alves Sobrinho, em comunicação pessoal, conta que o poeta, falando a respeito da amizade compartilhada entre ele e Átila Almeida, lhe disse que havia

\begin{abstract}
uma relação de respeito e, de certo modo, de igualdade. O Átila era muito irônico e brincalhão, dizia ao Sobrinho o que achava. Nem sempre estavam de acordo, prova é que tiveram muitos desentendimentos no final, como me deixou entender o poeta. Igualdade? O nome do Átila saiu na frente do de Sobrinho. Uma das razões era o fato do Átila ser um intelectual, como disse-me Sobrinho, "não ficava bem o meu nome sair primeiro".
\end{abstract}

Essa relação entre poetas e intelectuais, sempre presente no contexto de poéticas populares e orais, como o cordel, evidencia o outro lado da moeda: o pensamento de que os poetas necessitam de ajuda de intelectuais, que são os responsáveis, em primeiro lugar, pela preservação da cultura. Essa afirmação deve, contudo, ser relativizada, caso contrário, nega-se por completo a possibilidade de autoagenciamento dos mais variados agentes da cultura.

\title{
Raymond Cantel
}

Os olhares intelectuais sobre o cordel vieram não só de dentro de nosso país, mas também de fora. Entre os pesquisadores do exterior ${ }^{51}$, o que teve maior influência nesses estudos foi o professor Raymond Cantel, da Universidade de Poitiers e da Sorbonne, em Paris, que, de 1959 a 1984, realizou suas pesquisas sobre o cordel em suas andanças pelo Brasil. Essas pesquisas hoje podem ser lidas numa

51 Mark Curran, Ronald Dauss, Candance Slater, entre outros, também promoveram o cordel no exterior. 
coletânea das publicações de Cantel, Raymond Cantel: la littérature populaire brésilienne (Clément e Lemaire, 2005), e no grande acervo de folhetos, correspondências, gravações e outros materiais que compõem o Fonds Raymond Cantel, da Universidade de Poitiers ${ }^{52}$, inaugurado em 1996 e que mantém um programa de pesquisa intitulado Estudos comparados em tradições orais em sua relação com o mundo da escrita.

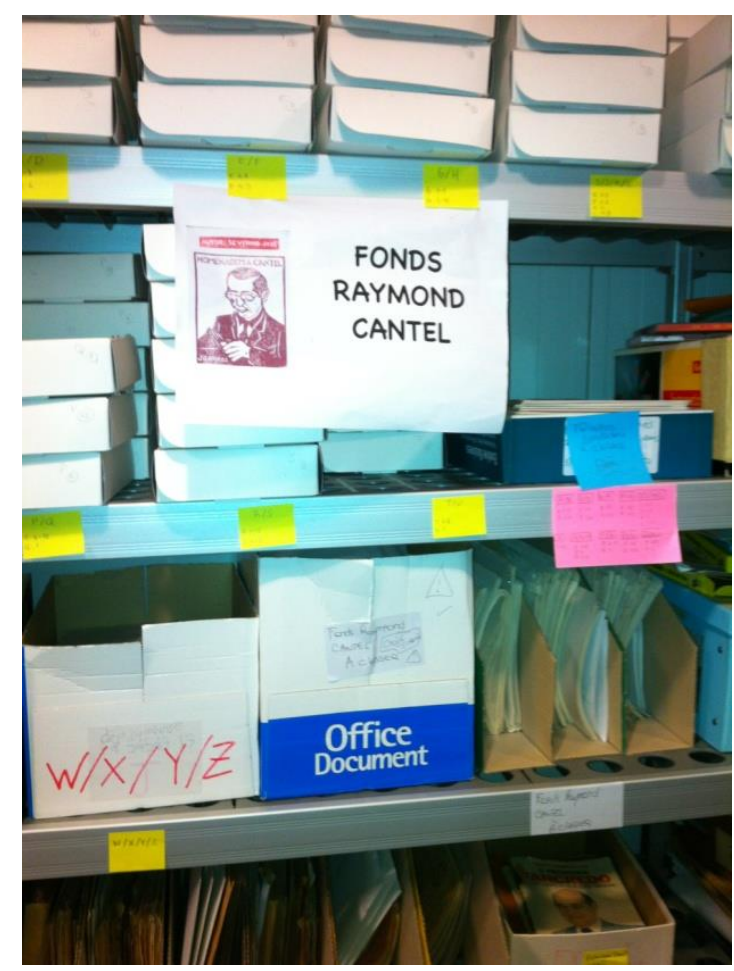

Estantes do Fonds Raymond Cantel

Se a FCRB deu o pontapé inicial para a definição do que é o cordel e o que, nesse sentido, deve ser preservado para que a história seja construída, Raymond Cantel $^{53}$, com sua posição de intelectual francês renomado de uma importante universidade europeia, foi o responsável, em grande medida, pela mudança de perspectiva de parte da intelectualidade sobre o cordel. Ele próprio ofereceu cursos que tinham por objeto de estudo o cordel, como a matéria que ministrou na importante Université Sorbonne Nouvelle - Paris III, entre os anos de 1970 e 1974; o curso de especialização sobre literatura de cordel que deu na Escola de Comunicação e Artes, da Universidade de São Paulo (USP) em 1972; e o curso sobre literatura de

\footnotetext{
52 Pude realizar importantes pesquisas para esta tese no acervo do Fonds Raymond Cantel de Littérature Populaire Brésilienne (Universidade de Poitiers), em dezembro de 2012, graças ao apoio do Ministério da Cultura (Brasil), mediante o Edital de Intercâmbio Cultural nº 1/2012.

${ }^{53}$ Raymond Cantel mantinha relação com os estudiosos da FCRB, embora não tenha publicado no projeto Litertura popular em verso.
} 
cordel e a sua influência na moderna literatura brasileira que promoveu na Universidade de Brasília (UnB), em 1976 (Santos, 2009).

Mas, vale ressaltar, essa mudança de perspectiva não originou uma mudança de paradigma nos estudos dessa poética. O cordel poderia até ser digno de estudos, entretanto, apenas um tipo de cordel.

Em cartas enviadas em 1977 por Veríssimo Melo a Cantel (Santos, 2011, p. 109), podemos perceber o sentimento de estranheza, e preconceito, dos estudiosos diante do surgimento de autores de cordel letrados, e até mesmo que possuíam curso superior, os quais os estudiosos não consideravam poetas populares, mas autores inautênticos e ilegítimos, justamente por terem instrução escolar maior que a dos verdadeiros, autênticos e espontâneos poetas populares.

Em outra carta, de Manuel Diégues Júnior a Cantel, uma cordelista é desconsiderada como tal por conta de sua escolarização, conforme atesta o seguinte trecho da carta: "No caso de Stella Leonardo, claro que não é literatura de cordel. Ela apenas tomou o modelo de cordel para elaborar sua poesia" (Santos, 2011, p. 107). No contexto de emissão dessa carta, enviada em 1977, pode-se falar não só em preconceito com poetas populares escolarizados, mas com mulheres escolarizadas.

Para os pesquisadores, poeta popular deve ser, necessáriamente, analfabeto ou semialfabetizado, uma vez que cordéis feitos por poetas letrados são meras imitações. A concepção de Cantel e Veríssimo assenta-se em ideias restritas sobre o "oral" e o "popular", fundamentadas em grande medida pelas ideias de Câmara Cascudo, segundo o qual "oral" se refere necessariamente ao que é produzido por aqueles que não detêm a tecnologia da escrita, analfabetos; e o "popular" relacionase ao produzido pelo povo, ou seja, pobres que conhecem apenas a tradição cultural popular.

Essas iniciativas de preservação e valorização do cordel foram vias de mão dupla, pois, na demarcação de fronteiras, deixou-se muito de fora e se prescreveu uma cartilha para o controle de uma poética que sempre fez parte da vida do povo de várias lugares do Nordeste e até mesmo de outras regiões do Brasil. A tentativa de controle dessa produção por instituições intelectuais e por intelectuais propriamente ditos nos revela uma antiga e tão recente vontade de controle de saberes e artes do povo por parte das elites, sejam intelectuais ou econômicas.

O pensamento de Roger Chartier sobre o processo de mediação editorial na Europa nos inícios das atividades editoriais aplica-se ao posicionamento de 
intelectuais e suas instituições no processo de construção do cânone do cordel. Entre "o receio da perda e o medo do excesso", esses discursos construtores do cânone do cordel foram responsáveis pela salvaguarda do patrimônio, com a coleta de textos e com "a organização dessas bibliotecas sem paredes que são os catálogos", e também foram responsáveis pelas ações de dominação do excesso, com seus instrumentos de seleção, classificação e hierarquização dessa poética (Chartier, 2002, p. 75-76). Esse fenômeno de mediação editorial também pode ser visto na publicação de poéticas populares por editoras hegemônicas, em contrapartida às tipografias de folhetos, como é o caso da editora Hedra.

\section{Coleção Biblioteca de Cordel}

A Coleção Biblioteca de Cordel, da editora Hedra, de São Paulo, foi lançada em 2000, tendo por idealizador e diretor o professor e pesquisador holandês Joseph Luyten. O projeto editorial, como já foi dito, previa o lançamento de cinquenta livros, sendo cada um destes dedicado a um poeta e prefaciado por um estudioso da área. Até o momento, foram lançados 22, sendo as últimas publicações do ano de 2007.

Com o falecimento do idealizador da coleção, Joseph Luyten, em 2006, as publicações foram encerradas. Em entrevista, a Editora Hedra afirmou que a Coleção, como um todo, também não teve o sucesso editorial esperado. Porém, contradizendo essa afirmação, tem-se a vendagem elevadíssima do livro de Patativa do Assaré, 80 mil exemplares, que consiste, a um só tempo, em obra de vendagem e de prestígio na Coleção - de vendagem por ser um paradidático literário adotado no vestibular da Universidade Federal do Ceará (UFC) em 2005, e no vestibular da Universidade Federal de Minas Gerais (UFMG) em 2006; e de prestígio por Patativa do Assaré ser o grande poeta popular nordestino, aclamado amplamente por público e crítica. É praxe das editoras lucrar com a venda de um único título e manter os demais, muitas vezes encalhados com esse lucro, mas isso não aconteceu com esse projeto, que foi interrompido, a despeito do apoio que recebeu. Das seis publicações do ano de 2007, cinco tiveram o apoio da Secretaria de Estado de Cultura do Governo do Estado de São Paulo. 
A tabela abaixo apresenta alguns dados da Coleção.

\begin{tabular}{lll}
\multicolumn{2}{l}{ Relação de cordelistas, prefaciadores e ano de lançamento da Coleção } \\
AUTOR & PREFACIADOR & ANO \\
Cuíca do Santo Amaro & Mark J. Curran & 2000 \\
Expedito Sebastião da Silva & Martine Kunz & 2000 \\
Francisco das Chagas Batista & Altimar de Alencar Pimentel & 2007 \\
Franklin Maxado & Antônio Amaury Corrêa de Araújo & 2007 \\
J. Borges & Jeová Franklin & 2007 \\
João Martins de Athayde & Mário Souto Maior & 2000 \\
José Soares & Mark Dinneen & 2007 \\
Klévisson Viana & José Neumanne & 2007 \\
Manoel Caboclo & Gilmar de Carvalho & 2000 \\
Minelvino Francisco da Silva & Edilene Matos & 2000 \\
Neco Martins & Gilmar de Carvalho & 2002 \\
Oliveira de Panelas & Maurive Van Woensel & 2001 \\
Patativa do Assaré & Sylvie Debs & 2000 \\
Paulo Nunes Batista & Maria do Socorro Gomes Barbosa & 2005 \\
Raimundo Santa Helena & Bráulio Tavares & 2003 \\
Rodolfo Coelho Cavalcante & Eno Theodoro Wanke & 2003 \\
Rouxinol do Rinaré & Ribamar Lopes & 2007 \\
Severino José & Luiz de Assis Monteiro & 2001 \\
Téo Azevedo & Sebastião Geraldo Breguez & 2003 \\
Zé Melancia & Martine Kunz & 2005 \\
Zé Saldanha & Gutenberg Costa & 2001 \\
Zé Vicente & Vicente Salles & 2000
\end{tabular}

Os livros da Coleção têm extensão variável de 70 a 234 páginas, das quais os prefácios ocupam de 14 a 77 páginas. A Coleção apresenta um cuidadoso projeto gráfico. Nas capas há uma xilogravura em cores vivas, com o nome do cordelista e o título cordel. Na contracapa, uma parte da xilogravura ampliada, também em cores vivas, e o trecho de um cordel. Nas orelhas, há mais xilogravuras e uma pequena apresentação do poeta. 


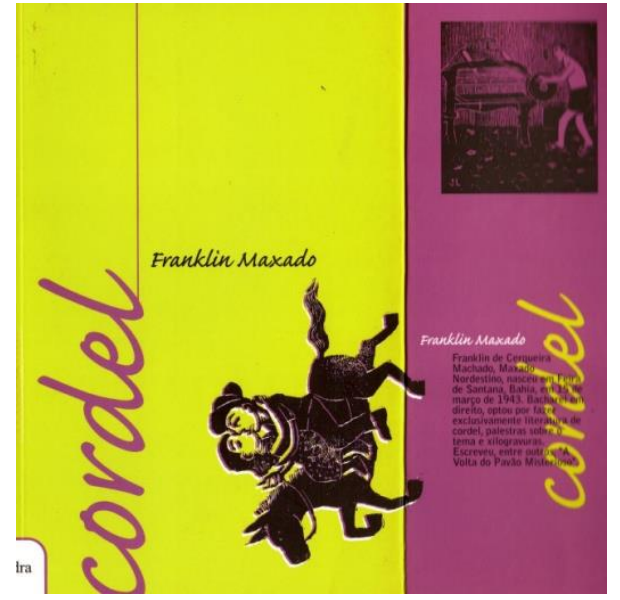

Capa e orelha do livro de Franklin Maxado, da Coleção Biblioteca de Cordel

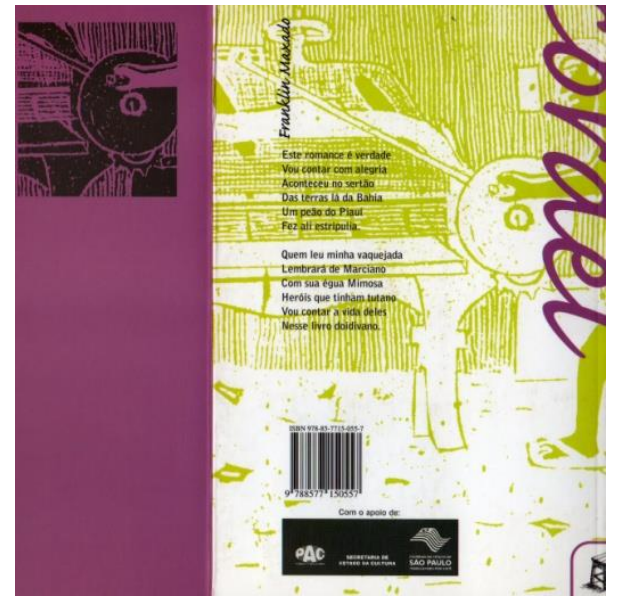

Contracapa e orelha do livro de Franklin Maxado, da Coleção Biblioteca de Cordel

Esta Coleção, com um seguimento editorial, gráfico e ideológico e, por isso, uma segmentação de mercado, identifica a poética (o cordel) antes de seus autores, que também são autores pertencentes ao cânone historiográfico construído pela FCRB, pelo Dicionário de Sobrinho e pelos estudos de Cantel. O que parece importar, desde o projeto gráfico, é o cordel como tradição única e homogênea. A inovação de seu suporte e editoração tanto constrói um novo status a essa poética como a afirma como uma obra, antes de qualquer coisa, que narra uma tradição coletiva. Parafraseando Hugo Achugar (2006) quando fala da literatura latinoamericana, o cordel, entendido como marca, só tem como objetivo preencher o vazio do mercado que lhe corresponde.

Não é desproposital os cordéis serem publicados nesta Coleção são sob o formato de livro, pois, ao mesmo tempo em que alude ao suporte do folheto em seu projeto gráfico, também dele se distancia o suficiente para fazer-se diferente. Sua proposta gráfica e editorial compreende um conjunto de livros destinado ao público leitor acadêmico e universitário, de uma forma geral. Exatamente por ser dirigido a esse público, o cordel é publicado nesse formato. Pelos processos de distinção, esse projeto editorial supre o gosto "cultivado" de leitores que reconhecem nessas publicações um claro marcador de classe que torna o livro diferente do folheto.

Assim como os poetas se empoderaram do livro como estratégia de legitimação de seu trabalho, também as editoras e os pesquisadores, com seus valores e concepções, utilizaram o suporte livro como forma de introdução dessa poética no 
mercado editorial hegemônico e no campo acadêmico. Luyten, o idealizador da Coleção, em sua apresentação, argumenta que

\begin{abstract}
ao contrário de outros países, como o México e a Argentina, onde esse tipo de produção literária é normalmente aceita e incluída nos estudos oficiais de literatura (...), as vertentes brasileiras passaram por um longo período de desconhecimento e desprezo, devido a problemas históricos locais, como (...) a excessiva imitação de modelos estrangeiros pela intelectualidade. Apesar da maciça bibliografia crítica e da vasta produção de folhetos (mais de 30 mil folhetos de 2 mil autores classificados), a literatura de cordel - cujo início remonta ao fim do século XIX - continua ainda em boa parte desconhecida do grande público, principalmente por causa da distribuição efêmera dos folhetos. E é por isso que a Editora Hedra se propôs a selecionar cinquenta estudiosos do Brasil e do exterior que, por sua vez, escolheram cinquenta poetas populares de destaque e prepararam um estudo introdutório para cada um, seguido por uma antologia dos poemas mais representativos ${ }^{54}$.
\end{abstract}

Os argumentos dizem muito a respeito das posições do campo literário acadêmico em relação ao cordel. A construção de uma visão sobre o cordel e, consequentemente, de sua historiografia e cânone, nos mostra o papel que os intelectuais e as suas instituições exerceram nesse contexto. A FCRB, o pesquisador Raymond Cantel e o Dicionário de José Alves Sobrinho e Átila Almeida, como visto, construíram uma história definindo não apenas o que é o folheto, mas quais são os que o escreveram e "merecem" ser lembrados. Como esses construtores de uma história sobre o folheto, a Coleção Biblioteca de Cordel tem o objetivo de preservação, manutenção, salvaguarda e valorização dessa poética.

O apego da intelectualidade a modelos estrangeiros é um dos argumentos enumerados por Luyten para compreender a subalternização do cordel. A literatura brasileira, de fato, nos inícios de sua formação, como o estudioso Antonio Candido nos mostra em toda sua obra, foi construída por meio de modelos da tradição europeia literária. Todavia, com a formação de um sistema literário autônomo em relação à Europa, artistas como Ariano Suassuna, que já fazia parte da história literária brasileira, dizem escrever hibridizando formas e temas eruditos e populares. Mário de Andrade, antes do dramaturgo Suassuna, utilizou-se dessa estratégia de composição, só para citar exemplos do uso, muitas vezes ingrato e autoritário, de temáticas e estruturas textuais não hegemônicas por intelectuais.

${ }^{54}$ Coleção Biblioteca de Cordel. Trecho da apresentação, que aparece abrindo todos os livros da coleção. 
O cânone do cordel também nos diz algo a esse respeito. A FCRB, imbuída de uma ideologia calcada na nação, utilizou-se do cordel para construir uma narrativa sobre a sociedade brasileira, seus costumes, conceitos, preconceitos, formação social e racial, entre outros aspectos. De modo que, foram os aspectos do cordel identificados com a nação, e não o apego a modelos estrangeiros, que participaram do processo de construção do cânone do cordel e da construção de sua definição como popular e, consequentemente, de seu apartamento da historiografia literária brasileira oficial e hegemônica. Sempre atrelado à região Nordeste, o cordel, na historiografia brasileira, teve uma dupla exclusão por sua classificação como popular. Em sentido amplo, como uma manifestação artística considerada popular e, por isso marginalizada da "grande Literatura Brasileira", uma vez que o adjetivo popular está aí para marcar uma distinção dessa literatura (popular) em relação à sem adjetivo. E, em sentido estrito, como uma manifestação das poéticas das vozes em meio a uma tradição literária firmada pelo escrito e por regras, classificações e gêneros, como a brasileira, foi também, por isso, marginalizada.

Dessa forma, seja por ser considerado popular, seja por ser de bases orais, o cordel foi subalternizado. Foi justamente a mão pesada de intelectuais, esforçados em classificar, disciplinar, preservar e registrar essa poética movediça das vozes, tendo sempre com o pano fundo a constituição da nação e a importância do popular nesse processo, que a restringiu a uma posição marginal dentro dos estudos literários. E a Coleção Biblioteca de Cordel, ao contrário do que Luyten diz, parece fazer o mesmo com todos os prefácios que afirmam uma mesma história ao cordel: uma narrativa estática e que assim deve permanecer como toda boa tradição e patrimônio popular.

A tentativa anunciada por Luyten de inserir o cordel nos estudos oficiais de literatura e de fazê-lo presente ao grande público - que é uma falácia, pois o público leitor de cordel (Galvão, 2001) é infinitamente maior que o público leitor acadêmico, por questões de acesso linguístico (a linguagem do cordel é mais acessível) e econômico (o preço do folheto também é mais acessível) que intermediam o acesso a determinados bens simbólicos - ocorre por meio de várias estratégias editoriais, como a utilização prefácios escritos por intelectuais que apresentam e legitimam o texto. 
A intervenção de mediadores (a partir dos prefácios) exerce forte influência na recepção de poéticas não hegemônicas ${ }^{55}$, como o cordel, em meios hegemônicos (o suporte livro). Junto a isso, podemos perceber que os prefaciadores são os mediadores que têm o "privilégio de definir" (Bourdieu, 2007, p. 88) um discurso sobre o que é o cordel, os seus valores e os seus limites.

Acerca do prefácio como tipologia textual e de seus significados na composição de obras, há poucos estudos. Um importante texto para a compreensão de seus significados é o de Ria Lemaire a respeito dos vários prefácios à Casagrande \& senzala de Gilberto Freyre. Para Lemaire,

\footnotetext{
todos esses relatos fora do texto (...) têm por objetivo, cada um a sua maneira, guiar ou manipular o leitor, a fim de que ele leia "bem" a obra, quer dizer, que ele aceite ou faça sua a mensagem, a verdade que o autor quis transmitir a seus contemporâneos e às gerações futuras (Lemaire, 2002, p. 734).
}

No caso da Coleção da editora Hedra, esses relatos fora do texto têm o objetivo claro de guiar o leitor a uma determinada leitura da obra, bem como o de criar, com o conjunto de obras que formam a Coleção, uma história sobre o cordel. Para "tornar familiar o não familiar" (White, 2001, p. 102), uma vez que o cordel se aproxima de um leitor atrelado aos "estudos oficiais de literatura" e ao "grande público", nas palavras de Luyten, distantes (cultural e economicamente) da realidade da poética do folheto de cordel.

Nesses livros, estudiosos do Brasil (15) e do exterior (5) apresentam os cordelistas e seus cordéis como uma forma de atribuir-lhes validade e legitimidade, como afirma o próprio diretor da Coleção. Adentrando as narrativas dos prefácios, muitas constantes são percebidas, a principal diz respeito à crença dos prefaciadores em uma mesma e única tradição do cordel como legítima. Essa crença é, ao mesmo tempo, reforçada, afirmada e definida por esses estudiosos. Como podemos ver na citação a seguir, em que Raimundo Santa Helena nos conta sobre a advertência que Raymond Cantel lhe fez um dia, há regras tradicionais que não devem ser infringidas, tanto segundo a visão do pesquisador Cantel como a do prefaciador Bráulio Tavares.

55 Ver: Lucena, 2009. 
Cantel sugeriu que eu não descaracterizasse os estilos e as rimas, o que eu fizera, tentando oferecer o cordel nas metrópoles ao sabor de novos leitores. Mudei e me submeti à força da tradição, a partir do folheto n. 13, de 21/12/1980, Discussão de São Pedro com Nelson Rodrigues (Helena, 2003, p. 13).

Por meio do que Cantel disse a Raimundo Santa Helena, podemos perceber a vontade de um discurso tradicional sedimentado de encerrar a produção de cordelistas no interior de estreitas fronteiras. Segundo Néstor García Canclini, como "os movimentos populares também estão interessados em modernizar-se", os setores hegemônicos estão interessados "em manter o tradicional, ou parte dele, como referente histórico e recurso simbólico contemporâneo" (Canclini, 1998, p. 277). Todavia, nessa espécie de queda de braços entre a permanência (que fossiliza) e a modernização (que perpetua), os prefácios apresentam-se como formas de dominação dessa poética. Nos prefácios feitos pelos estudiosos do cordel, ao invés de se plantar uma visão viva do cordel, como uma tradição que se refaz com o girar do mundo, se enterra a possibilidade de florescimento a cada estação dessa poética. As antigas e atacadas medidas discriminatórias as quais Luyten critica na apresentação da Coleção, nos prefácios de sua mesma Coleção tornam-se limites bem definidos de contenção. As mudanças são interditadas, sejam elas formais ou temáticas, por especialistas, autorizados.

Assim, os prefácios funcionam como locais de perpetuação de uma história que é justificada e harmonizada pela coerência das vozes que falam. Os discursos alinhados dos prefaciadores criam, contam e reforçam uma só história sobre o cordel e, ao mesmo tempo, abafam a polifonia das vozes que essa rica poética possui.

Afastando a possibilidade de ruptura, como fez Cantel com Santa Helena, condena-se a poética à estagnação e, consequentemente, à sua morte, visto que a vontade de permanência que os prefaciadores defendem, destituída de mudança, acaba tirando do cordel sua força de movência e de transformação. O desejo do tradicional como espaço de permanência pode ser visto no seguinte trecho do prefácio de Martine Kunz à obra de Expedito Sebastião da Silva (2001, p.14): “A forma rígida, dogmática, é também resistente, mineral. Uma imensa rede de versos e palavras, de rimas e vozes que prende e protege na sua forma imóvel, retém e exalta, ao mesmo tempo, uma arte ameaçada".

A centralidade dos intelectuais na perpetuação dessa poética também é sublinhada no prefácio à obra de Patativa do Assaré, em que a pesquisadora francesa 
Sylvie Debs, ao fazer amplo panorama da obra e vida do poeta, põe em evidência a importância de intermediadores na publicação de cordéis, uma vez que Patativa do Assaré nunca buscou a publicação de seus versos, sendo seus admiradores os responsáveis. Como dito anteriormente, os poetas utilizam do prestígio do suporte livro e da legitimidade de mediadores para a publicação de suas obras, todavia, não se pode perder de vista que nessa relação entre poetas e pesquisadores (acadêmicos ou não) a importância dos mediadores é diretamente proporcional à importância dos poetas no cenário dessas poéticas.

Sublinhar a erudição dos poetas, entendida pelos prefaciadores como o consumo de obras clássicas da tradição erudita, é outra forma de atribuição de valor, assim como faz o prefaciador Altimar de Alencar Pimentel quando narra a busca de Francisco das Chagas Batista pela erudição, tornando-o alvo de gozação por ler o cânone literário hegemônico. A erudição dos cordelistas é posta em questão como forma de legitimar o que eles escrevem por vários prefaciadores. Mark J. Curran, no prefácio à obra de Cuíca do Santo Amaro, compara o estilo do poeta ao de Gregório de Matos, Castro Alves e Jorge Amado, ressaltando também o fato de o poeta ser personagem de escritores como Jorge Amado e Dias Gomes. No prefacio à obra de Patativa do Assaré, o emparelhamento de sua obra à de escritores da literatura hegemônica, como Graciliano Ramos e Raquel de Queiroz, no que tange à formação de uma identidade nordestina, também é motivo para se valorizar. Dessa forma, a porta de entrada dos poetas para o salão das "obras populares", importantes por seu valor como "documento", como afirma o prefaciador em questão, é a sua parecença com obras de escritores eruditos, uma vez que a tradição crítica do cordel (e de toda a literatura) é "referenciada na tradição europeia de uma cultura de elite que se legitimou e se propagou através da identificação dessa mesma cultura com os valores ditos universais" (Schmidt, 1996, p. 117).

A relação entre popular e erudito, oralidade e escrita, é, muitas vezes, utilizada como forma de desvalorizar a oralidade como uma estética de composição.

(Cuíca do Santo Amaro) não estava entre os melhores versificadores da literatura de cordel, mas era síntese do trovador-repórter popular (...). Entende-se, claro, que Cuíca fazia uma reflexão popular, não erudita, porque em termos artísticos seu verso era pobre. Cuíca de Santo Amaro era uma espécie de Gregório de Matos Guerra sem gramática (Amaro, 2000, p. 9-15). 
O lugar de Cuíca na historiografia do cordel é atribuído pelo prefaciador por sua importância como repórter e personagem da história baiana e não por sua relevância como artista, que também é diminuída pela comparação de sua poesia com os códigos da escrita e da erudição, tidos como superiores. Também Sylvie Debs, no prefácio à obra de Patativa, desvaloriza as formas de composição da oralidade não as reconhecendo: "a versificação utilizada (...) parece ser mais a expressão de uma técnica de memorização que a expressão de uma forma poética erudita" (Assaré, 2005, p. 13). O que a pesquisadora não cogita é a utilização de uma expressão poética popular, passada oralmente.

Essas e outras estratégias discursivas são utilizadas nos prefácios para se contar a história responsável pela fixação de um discurso historiográfico e de um cânone do cordel. Todavia, enquanto a FCRB, o pesquisador Raymond Cantel e o Dicionário tiveram a perspectiva de construir e legitimar um cânone a fim de construir uma historiografia do cordel, a Coleção Biblioteca de Cordel da editora Hedra constitui-se a partir do pressuposto estabelecido por esta historiografia. Dessa forma, todas essas instâncias fomentaram a construção e a manutenção de um "sistema de representação" (do que os cordéis deveriam representar) e de interpretação (o que deveria se estudar nos cordéis), pensando analogamente a Schmidt (1998, p. 183-184).

Esses discursos parecem não querer olhar para o outro processo de exclusão que produzem. Divulgar o que alguns entendem por cordel nem sempre é a melhor maneira de divulgar essa arte (selecionada previamente por intelectuais e por eles canonizadas e controladas). Ao mesmo tempo em que é uma ação de divulgação, é um procedimento para assegurar a distinção entre os que cabem e os que não cabem dentro dessa tradição controlada em gabinetes. Esses estudos expressam uma vontade de constituição e delimitação do cordel, a partir da qual "cabe determinar certas regras de validade epistemológica; porém (são) também um mecanismo de controle e autoridade do saber que, em nome de certos limites de seleção e inclusão/exclusão, se encarregam de cuidar da pureza e integridade de seus corpus" (Richard, 2002, p. 197).

Há muito se sabe que não é possível haver tradição sem a sua contraparte, a inovação, sendo as tensões entre essas duas instâncias as responsáveis por sua permanência. O nascimento de novos cordelistas, com suas inovações formais e 
temáticas, ao contrário do que os prefaciadores postulam, tem contribuído muito para que as obras do passado sejam reavivadas e revalorizadas. Quando, por exemplo, as cordelistas mauditas ${ }^{56}$ Francisca (Fanka) Pereira dos Santos e Salete Maria da Silva escrevem Dimas, o bom ladrão? (Santos e Silva, 2004), dando novo significado ao cordel de Francisco das Chagas Batista, Dimas, o bom ladrão, elas transformam uma narrativa de um homem injustiçado pela maldade dos que matam seu pai - por uma dívida também injusta, e que por isso se torna assassino - em uma história de desigualdade social, corrupção, desnaturalizando a violência e seus resultados e a politizando. Nessa "narrativa que rasura a primeira que deu origem" (Schmidt, 1998, p. 196), as cordelistas não só estão fazendo girar a roda do cordel, como também estão lembrando que outros já a rodaram.

${ }^{56}$ Esse adjetivo é utilizado para qualificar as cordelistas que integraram a A Sociedade dos Cordelistas Mauditos. 


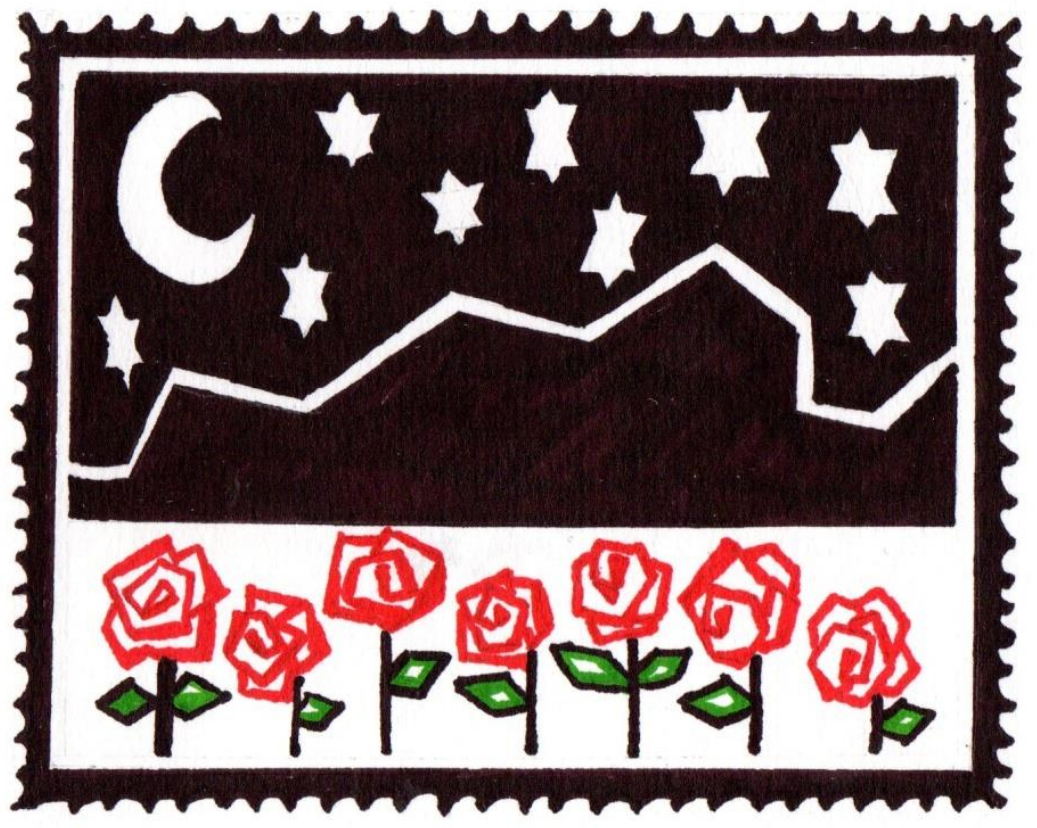

I I _ POÉTICAS A CÉU ABERTO 
Que o impossível seja pouco para nós.

Sérgio Vaz

Desde meados da década de 1970 do século passado, em resposta a discursos que declaravam a morte do cordel, iniciou-se a formação de uma série de organizações de poetas populares que reivindicavam a permanência e produtividade dessa poética, ou mesmo atestavam a sua existência. Destacam-se entre elas a Ordem Brasileira de Poetas de Literatura de Cordel (OBPLC), criada em 1976 por Rodolfo Coelho Cavalcante; a Federação Nacional de Cantadores Repentistas e Poetas Cordelistas (FENACREPC), fundada em Ceilândia (Distrito Federal), em 1982; a Associação de Repentistas e Cordelistas do Brasil, concebida por Expedito Ferreira da Silva, em 1986; o Centro Cultural dos Cordelistas do Ceará (CECORDEL), instituida em Fortaleza, em 1987, pelos poetas Otávio Menezes, Guaipuam Vieira e Jotamaro; e a Academia Brasileira de Literatura de Cordel (ABLC), estabelecida no Rio de Janeiro por Gonçalo Ferreira em 1988.

Já em 1991, foi estabelecida, por iniciativa de Elói Teles, a Academia dos Cordelistas do Crato (ACC), na cidade do Crato (Ceará), vizinha a Juzeiro do Norte, do Padre Cícero, onde se forma, em 2000, outra organização, a Sociedade dos Cordelistas Mauditos. Essas agremiações surgiram em um contexto de estímulo ao cordel na região do Cariri, propiciado pelos projetos Cordel Vivo ${ }^{57}$ e SESCordel Novos Talentos.

A Academia de Cordelistas do Crato compõe-se de doze cordelistas, sendo sete mulheres autoras: Anilda Figueiredo, Francisca Oliveira (Mana), Josenir Amorim, Maria do Rosário Lustosa, Maria do Socorro Brito, Maria Nezite e Sebastiana Gomes de Almeida Job (Bastinha). A Academia fundamenta-se no resgate do cordel e no entendimento dessa poética como autêntica, pura, imutável, aos moldes do pensamento tradicional consolidado no processo de institucionalização do cordel.

Uma das cordelistas com maior produção da ACC é Sebastiana Gomes de Almeida Job, mais conhecida como Bastinha, que participa da agremiação desde sua primeira reunião, em janeiro de 1991. Em viagem à cidade do Crato, em novembro

${ }^{57}$ Projeto criado pelo poeta Abraão Batista, em sua administração do Memorial Padre Cícero, órgão ligado à Prefeitura Municipal de Juazeiro do Norte, que vigorou entre os anos de 1996 e 1997. 
de 2009, conheci a cordelista, além de alguns outros integrantes da Academia que puderam me contar um pouco sobre o seu funcionamento e suas concepções, que se coadunam com as do discurso construído sobre o cordel pela FCRB, por Cantel, pelo Dicionário de Sobrinho e Átila e pela Coleção da Hedra. Conheci, ainda, as dependências da Academia, que conta com uma tipografia e uma biblioteca com sala de reuniões, chamada Sala Cego Aderaldo.

A Sociedade dos Cordelistas Mauditos, por sua vez, nasceu em primeiro de abril do ano 2000, com o lançamento de doze cordéis intitulados Agora são outros quinhentos, sendo integrada por doze poetas, dos quais quatro são mulheres: Salete Maria da Silva, Fanka Santos, Camila Alenquer e Jô Andrade. Desde 2007, a Sociedade desintegrou-se como grupo, mas seus integrantes continuam publicando isoladamente, em um movimento poético de mudança, afirmação e questionamento da tradição, inovando tanto em questões formais quanto ideológicas, além de se voltar a outros públicos. No que diz respeito à questão formal, o mote era a intertextualidade e o hibridismo entre a linguagem popular e a erudita. Já no que tange ao conteúdo, o objetivo do grupo era desconstruir as visões discriminadoras, como a perspectiva sobre as mulheres e sobre os negros, imbuídas em grande parte das obras de cordel.

A palavra maudito, grafada com "u", refere-se ao fato de os poetas afirmarem que produzem um cordel ruim e mal feito, ou seja, fora dos moldes da tradição, reelaborando e questionando os preceitos estabelecidos sobre o que é o cordel. Ao romper com os formatos e temas da tradição do cordel, os cordelistas mauditos expressam seu desejo de abertura a novas formas e temas, ao mesmo tempo em que denunciam a clausura que a tradição por vezes defende.

Uma das idealizadoras e fundadoras da Sociedade dos Cordelistas Mauditos é Salete Maria da Silva, que, no ato de criação da Sociedade, lançou com Fanka Santos o cordel Joca e Juarez. Hoje ela publica a todo vapor seus cordéis por meio do blogue Cordelirando (<www.cordelirando.blogspot.com〉), criado e coordenado por Sammyra Santana desde junho 2008. O uso da blogosfera como tecnologia de publicação afirma sua independência quanto à distribuição de sua poética e já indica a busca de grande alcance do público na visão da autora, que emprega, ainda, a tradicional publicação via folheto ilustrado com xilogravura. 
A presença de diversas mulheres cordelistas nessas organizações, sendo elas, inclusive, centrais, por sua extensa produção artística, já contradiz a história repetida pelo cânone historiográfico do cordel, segundo o qual não há mulheres cordelistas.

\section{0 céu é para todas: mulheres cordelistas}

A pesquisadora e cordelista Francisca Pereira dos Santos, em conversa informal com Joseph Luyten, diretor da Coleção Biblioteca de Cordel da editora Hedra, perguntou-lhe o porquê da ausência de mulheres autoras. A resposta foi que as autoras não eram relevantes para a proposta da Coleção - nem mesmo a cordelista Bastinha, que àquela altura já havia publicado mais de 20 títulos -, pois considerava ínfima a quantidade de folhetos produzidos pela cordelista e pelas cordelistas de uma forma geral (Santos, 2009).

O critério de admissão de uma obra ou de um autor na historiografia do cordel, ou melhor, em seu cânone, que possivelmente poderia ser a advogada qualidade estética da obra, no discurso de Luyten foi substituído por outro critério, o do número de obras produzidas. Entretanto, se este critério é utilizado para as cordelistas mulheres, para os cordelistas homens ele não se apresenta como válido, como se pode ver na inclusão do poeta Severino José na Coleção, uma vez que ele produziu um total de quinze folhetos em toda sua vida. A pesquisadora estadunidense Candace Slater, que realizou uma grande pesquisa sobre o cordel no Brasil entre os anos de 1977 e 1979, tem concepção semelhante à de Luyten, repetindo uma ideologia misógina. Para ela,

\footnotetext{
as mulheres têm tradicionalmente auxiliado os maridos ou pais, quando autores, a escrever e rever histórias, e tem havido algumas famosas mulheres repentistas; porém, hoje, apesar de poder-se encontrar um ocasional folheto escrito por mulher, praticamente todos os profissionais são homens (Slater, 1984, p. 27).
}

Por trás da afirmação de que as mulheres auxiliaram maridos e pais a escrever e a rever histórias está, muitas vezes, o fato de elas terem escrito cordéis e de não terem os assinado, como foi o caso de Maria José de Athayde, filha de João Martins de Athayde (Athayde, 2005, p. 60). E, como vimos acima, a existência de um “ocasional folheto escrito por mulher" pode não ser tão ocasional assim. Além de a quantidade de folhetos, para ser considerada significativa, ser uma para autores e outra para autoras. 
Dessa forma, apesar de a existência do cordel ultrapassar um século em solo brasileiro e serem inúmeros os autores homens a compor essa historiografia, a presença de mulheres cordelistas ainda é pequena. Até 1950, registra-se uma cordelista, a paraibana Maria das Neves Pimentel (nascida em 1913), que, para publicar seus folhetos (O corcunda de Notre Dame - 1935, O amor nunca morre1938, e $O$ violino do diabo ou o valor da honestidade - 1945), vestiu-se de um pseudônimo masculino, Altino Alagoano (Mendonça, 1993). A utilização de pseudônimos foi uma forma que essas mulheres encontraram para se inserir no território do cordel. Maria das Neves Pimentel afirma que utilizou o nome de homem para assinar seus folhetos, pois, "se botar (o próprio nome, de mulher) não vende" (Pimentel apud Mendonça, 1993, p. 70). Assim, ao passo que seu pai, Francisco das Chagas Batista, entrou para a história do cordel, estando nas antologias da FCRB e na Coleção da Hedra, Maria não consta nessas histórias ${ }^{58}$.

Maria das Neves Pimentel é prova de que não é porque as cordelistas não estão na historiografia que elas não existiram. Os elementos que contribuíram para a formação desse monopólio masculino são muitos, menos a inexistência de cordelistas mulheres. O motivo mais evidente é a circunscrição de mulheres ao mundo privado, uma vez que, sendo o cordel uma poesia nômade, o acesso à publicação e à divulgação de seu trabalho se tornava mais difícil. Mesmo assim, elas existiram e resistiram, como nos mostra a recente pesquisa de Francisca Pereira dos Santos (2009), que catalogou 221 mulheres cordelistas, com 872 títulos publicados. Como afirma Santos (2011, p. 51),

\footnotetext{
as mulheres só passaram a publicar seus folhetos a partir da inserção no mercado de trabalho e a partir do momento em que tiveram acesso aos códigos de escrita - como ocorreu com Stella Leonardo, Josenir Lacerda, Salete Maria da Silva, Bastinha.
}

Vale destacar que o crescimento do número de mulheres cordelistas se insere em um contexto de desenvolvimento do feminismo militante e acadêmico. Se as mulheres das classes trabalhadoras sempre tiveram o acesso ao mundo do trabalho e à esfera pública de um modo geral, o mesmo não aconteceu em relação aos espaços de criação e projeção social, até por conta do não domínio da escrita. Com o empoderamento das mulheres e a democratização da educação e da escrita, movidos,

\footnotetext{
${ }^{58}$ No Dicionário de Sobrinho, há menção a algumas cordelistas.
} 
também, pela militância feminista, a produção de cordéis de mulheres foi aumentada em número e visibilidade.

Registra-se que, na fundação da ABLC, em setembro de 1988, participaram como fundadoras três mulheres: Mirian, Eunice Cézar Souza e Maria do Livramento, mas não se sabe se escreviam, já que não se encontra nenhum folheto de suas autorias. É somente a partir da década de 90 do século passado que elas passam a compor os grupos, a exemplo da Academia dos Cordelistas do Crato, que se inicia com a presença de Bastinha e Josenir, e da Sociedade dos Cordelistas Mauditos, que não só será composta por mulheres, como será idealizada por elas, em especial por Salete Maria da Silva.

Sebastiana Gomes de Almeida Job, a Bastinha, e Salete Maria da Silva são respostas às lacunas estabelecidas pelo discurso da FCRB, de Cantel, do Dicionário e da Coleção, e apresentam um outro ponto de vista sobre o que é o cordel. Essas cordelistas lidam de formas diferentes com as estruturas de gênero em seus cordéis. A primeira aproximando-se de uma concepção mais tradicional de cordel e de valores e perspectivas também mais tradicionais, e a segunda se distanciando e se distinguindo desses aspectos da tradição. Essas cordelistas encontram-se, todavia, na relação que estabelecem com os mundos da oralidade e da escrita e, consequentemente, do sertão e da cidade. Bastinha, assim como Salete, são cordelistas que apresentam origens sertanejas e continuamente as reafirmam em suas obras como sendo o lugar de pertencimento. Entretanto, ao contrário dos poetas tradicionalmente do sertão, as cordelistas são da academia, ambas são professoras universitárias. Assim, as cordelistas reúnem, a um só tempo, a tradição oral e a escrita, o mundo rural e o urbano.

O livro Romaria de versos, publicado por Francisca Pereira dos Santos, em 2008, pelo SESC, consiste em uma publicação paradigmática para a divulgação dessas cordelistas, tendo sido a obra por meio da qual tive contato com o universo feminino do $\operatorname{cordel}^{59}$.

Maria Firmina dos Reis, citada anteriormente, ainda que tenha publicado Úrsula em 1859, teve sua obra desconhecida pelo público leitor, em decorrência, até mesmo, de sua não republicação, o que ocorreu por diversas razões, e de não estar

\footnotetext{
${ }^{59}$ Anteriormente às pesquisas feitas por Francisca Pereira dos Santos, registra-se apenas o estudo de Maristela Barbosa de Mendonça, intitulado Uma voz feminina no mundo do folheto (1993), sobre a autoria de mulheres no cordel.
} 
presente nas obras críticas e historiográficas de nossa literatura. A atual crítica literária feminista foi quem trouxe outra vez à luz Úrsula, em um processo de releitura de nossa história literária e de busca de autoras e obras obliteradas em razão de diversos mecanismos preconceituosos e discriminatórios.

Como ressalta Heloísa Buarque de Hollanda, há uma preocupação por parte das mulheres de antologizar a sua produção com o objetivo de romper a "lógica do esquecimento" (Hollanda, 1993) da literatura. E Francisca Pereira dos Santos, como pesquisadora, e também como cordelista, tem a preocupação de trazer à tona essas cordelistas, inserindo-se em um contexto de estudos e pesquisas recentes que "estão alterando o mapa da produção literária e a própria configuração da historiografia oficial" (Schmidt, 1996, p. 119).

Em Romaria de versos não se objetivou apenas fazer uma crítica revisionista do cordel, resgatando e relendo as obras dessas cordelistas, mas, pretendeu-se fazer, como defende Virgínia Maria Vasconcelos Leal, uma "leitura feminista de quaisquer textos" (Leal, 2008, p. 220), dando visibilidade a autoras excluídas de antologias de cordel. Pode ser realizada uma

\footnotetext{
revisão dos discursos críticos e seus pressupostos valorativos, já que são eles responsáveis, em última análise, pela manutenção de uma certa definição de literatura (neste caso, do cordel) que garante a legitimidade de certas obras, não por coincidência as de autoria masculina (Schmidt, 2002, p. 111).
}

Explicitando, abertamente, como também defende Rita Terezinha Schmidt, a vinculação "entre interesse e conhecimento", flagrando o interesse, ou o comprometimento, que antecede o conhecimento e que é responsável pela formação de uma epistemologia e dos valores por ela criados, a crítica feminista, ao questionar a universalidade de uma única definição das coisas, neste caso do cordel e da autoria de mulheres, busca, por meio da desestruturação e da desconstrução, a democratização do cânone e o estabelecimento de um multiculturalismo dialógico (Schmidt, 1994, p. 28), sendo estes um dos objetivos desta tese.

Mesmo compreendendo que a relação sexo - gênero - sexualidade, como uma linha reta, sem outros trânsitos possíveis, enclausura pessoas e seus corpos a uma normatividade e a uma hegemonia de possibilidades, essa constatação ainda não excluiu, ou mesmo deslegitimou, as lutas dos movimentos feministas enquanto estudos de gênero e de mulheres. A utilização de um "essencialismo operacional", 
como Spivak defende, é um recurso pelo qual o emprego do termo "mulheres" é utilizado para traçar uma conexão solidária entre as mulheres nas lutas contra as desigualdades de gênero, mesmo sabendo que tal signo carece de base ontológica. $\mathrm{O}$ que o corpo carrega e o que o constrói está cercado de relações de poder, por isso a discussão e o questionamento sobre o local das mulheres como sujeitos autores e o conhecimento e o reconhecimento de sua autoria se fazem necessários. Como Judith Butler afirma, desconstruir o conceito de mulher "significa continuar a usá-lo, repetilo, repeti-lo subversivamente, e deslocá-lo dos contextos nos quais foi disposto como instrumento do poder opressor" (Butler, 1998, p. 26).

Nesse rastro, as cordelistas Bastinha e Salete, ao trabalhar em suas obras as marcas de gênero, cada uma à sua maneira - afirmando ou não sua vinculação existencial, poética e política com essa questão -, fazem parte desse processo de desconstrução de uma história e de construção de outras. Inserindo-se em um contexto em que paulatinamente as autoras de cordel vêm publicando suas obras, porque possuem acesso à escrita, elas nos contam histórias que, ao mesmo tempo em que são representações e estetizações da vida de mulheres, são textos críticos e teóricos sobre essa poética.

\section{0 deboche no cordel de Bastinha: submissão estratégica e desobediência tácita}

Sebastiana Gomes de Almeida Job, mais conhecida como Bastinha, nasceu em 20 de janeiro de 1945, na serra de Santo Amaro, na cidade de Assaré, onde a partir dos dez anos começou a compor cordéis. Filha dos agricultores Maria Pereira Almeida e Miguel Gomes de Almeida, é a última de uma prole de vinte e um. Atualmente vive no Crato e é professora aposentada de Língua Portuguesa da Universidade Regional do Cariri (URCA), e uma das mais importantes cordelistas do cenário contemporâneo, tendo já publicado, até o presente momento, quarenta e quatro folhetos, conforme tabela a seguir, além de ser integrante da cadeira número quatro da Academia de Cordelistas do Crato $^{60}$.

\footnotetext{
${ }^{60}$ Em 1997, Bastinha muda-se da cidade do Crato para a de Juazeiro do Norte (ACC), cidades cearenses vizinhas. Após dois meses de sua mudança, foi expulsa da Academia dos Cordelistas do Crato, em razão de, segundo o regimento dessa instituição, ser regra os membros residirem no Crato, argumento levantado pelo então presidente da agremiação. Patativa do Assaré trocou algumas cartas (em verso) com Bastinha e com o fundador da ACC defendendo a permanência da cordelista.
} 


\section{Relação de cordéis de Sebastiana Gomes de Almeida Job}

130 anos de sertão

250 anos de música, preito a Pe. Ágio Moreira

3 A água é fonte da vida, não deixe a água morrer

$4 \quad$ A saga do professor

5 A sogra no folclore

6 Adivinhação no cordel

7 As proezas dos João Grilo brasileiros

8 Brasil 500, comemorar o que?

9 Centenário de Patativa do Assaré

10 Cordel no quadrão perguntado

11 Crato, cadê?

12 Dona Flor e seus namorados

13 Escolhe, pois, a vida

14 Felizes os que promovem a paz

15 Forró bom é no sertão

16 Frases de pára-choque

17 Fraternidade e Amazônia, vida e missão nesse chão

18 Grito ecológico

19 Levanta-te, vem para o meio

20 Lula, cadê?

21 O Brasil pode tudo menos ser consciente e honesto na jornada

22 O computador no cordel

23 O corno e a tipologia

24 O corno e a tipologia II

25 O filho que levantou falso a mãe

26 O frade e a freira ou a lenda do amor perdido

27 O homem que engarrafava nuvens

28 O poeta em versos faz desenhos maravilhosos

29 O povo sabe o que diz

30 O professor da Urca e o fundo de garantia

31 O que você quer saber sobre higiene

32 Oração à natureza

33 Patativa do Assaré na aula da saudade

34 Pegando carona

35 Pela cura natural

36 Por que tem tanta viúva

$37 \quad$ Prece de uma solteirona

38 Santa Luzia protetora dos olhos

39 Santo Antonio responde à solteirona

40 Se queres ser meu amigo não fale mal de meu Crato!

41 Só quem segura os caídos é Deus e o sutiã

42 Turismo e ecologia

43 Vocês não podem servir a Deus e ao dinheiro

$44 \quad$ Voto do matuto desiludido

Adentrando a obra de Bastinha, percebe-se que seus cordéis, de alguma forma, dão continuidade a uma tradição temática e formal desta poética, e mesmo os valores tradicionais são cultivados. De acordo com a própria autora, Patativa do Assaré é seu maior influenciador (Santos, 2011, p. 40), e o poeta do Assaré também confirma a filiação poética, a que denomina, na carta em verso trocada com Bastinha em 1991, de "água da mesma onda" (Santos, 2011, p. 82-83). 
Além disso, Patativa também exerce a função de crítico da obra da autora em outras cartas, funcionando, muitas vezes, como legitimador da obra de Bastinha. E, embora a poeta seja uma mulher do mundo da escrita, sendo inclusive professora universitária de língua portuguesa, ela preserva em seus cordéis o estilo popular e a linguagem matuta. Isso é o que a aproxima de Patativa do Assaré, que, "ao contrário dos intelectuais que excluíram Stella Leonardo por ser letrada", entende que a escolaridade é o que permite "transitar entre os vários mundos, o erudito e o popular, o oral e o escrito, a cidade e o sertão" (Santos, 2011, p. 86 e 98).

As personagens de Bastinha, todas bem populares, são matutos, solteironas, namoradeiras, cornos e outras figuras do imaginário popular. O deboche e o riso, na forma do cômico, são amplamente utilizados como estratégias discursivas, sendo um importante recurso estilístico e ideológico empregado pela autora para fazer, também, críticas sociais.

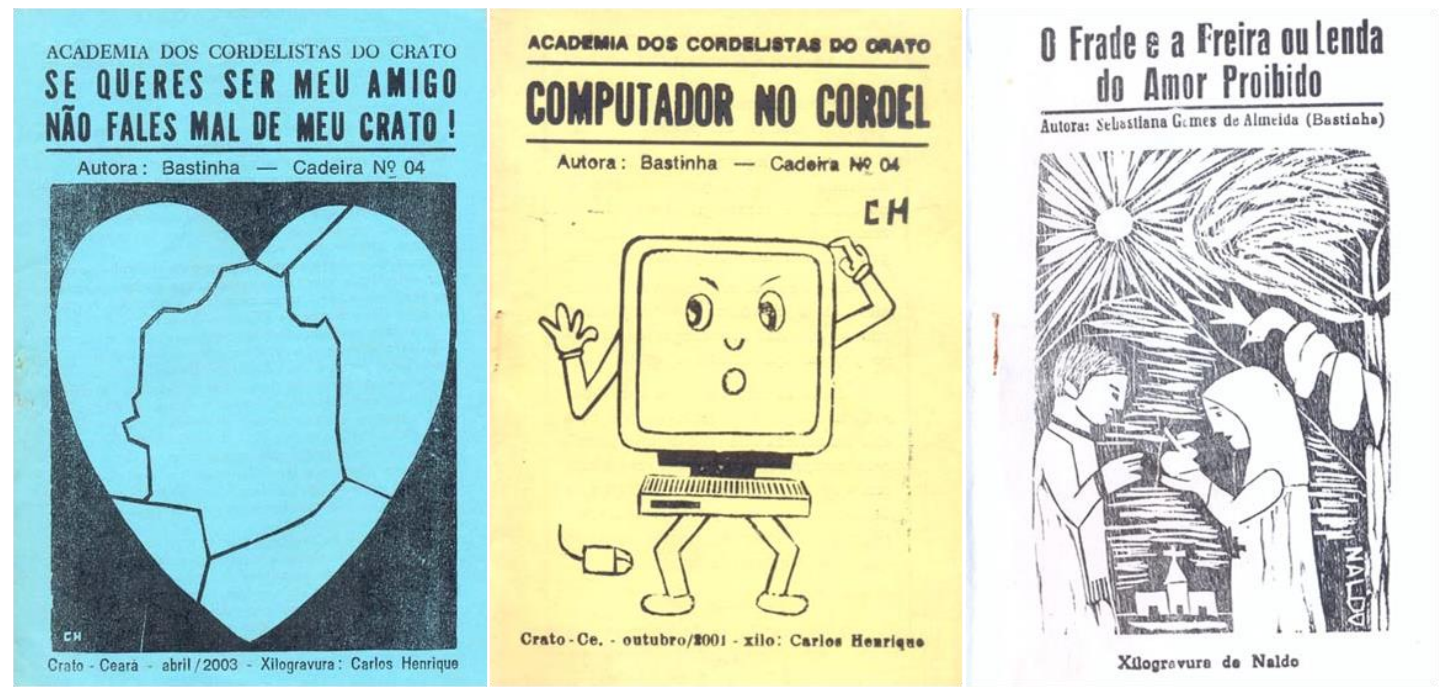

Capas de cordéis de Sebastiana de Almeida Job

Em seu cordel Prece de uma solteirona, de 1991, narrado em primeira pessoa por uma narradora-personagem, nos é contada a história de uma mulher que busca desesperadamente um marido. Já entre os trinta e quarenta anos, ela procura a felicidade de ter um homem ao seu lado. Para isso, faz de tudo: reza para todos os santos, realiza simpatias e bruxarias, reiterando a figura medieval da mulher feiticeira. Não tendo seu objetivo alcançado, pede diretamente a deus. O cordel consiste neste momento em que a narradora-personagem se dirige a deus e conta sobre sua peregrinação sem sucesso em busca de um marido. Confessando-se 
fracassada, a solteirona, como é chamada no cordel, sente-se, de alguma forma, redimida. Como Foucault postula, a confissão é uma forma de produzir sentido sobre si, de inocentar-se, purificar-se, livrar-se de suas faltas, libertar-se e garantir para si a salvação (Foucault, 1993, p. 8). Assim, ao confessar sua triste situação, a solteirona de Bastinha enobrece-se por meio do assujeitamento confesso aos ideais do casamento.

Esse cordel de Bastinha bem como outros representam mulheres em situações marginais ao casamento. Apesar de o casamento aparecer como central à existência das personagens, suas mulheres estão deslocadas deste ideal, mesmo que a contragosto, como é o caso da personagem de Prece de uma solteirona. Para explicar seu fracasso frente ao matrimônio, a narradora nos diz:

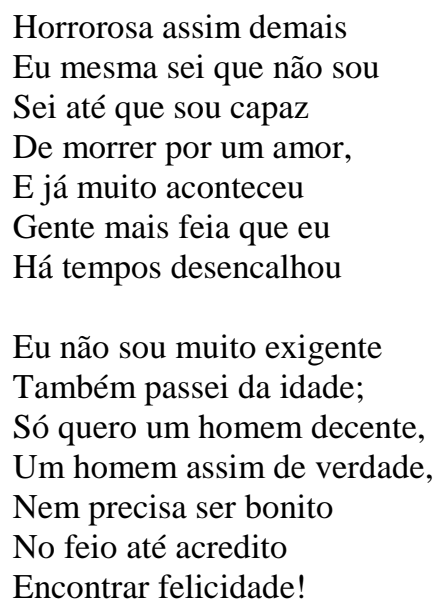

Apesar de a personagem achar-se competitiva no mercado do casamento em relação à sua beleza, sente-se em desvantagem por conta de sua idade, restando-lhe qualquer um que a queira, no fim das contas. Esse é o tom do cordel, que pode ser encontrado em vários outros, visto que a solteirona é uma personagem amplamente difundida no imaginário popular, principalmente como uma mulher infeliz e sofredora.

O próprio termo, solteirona, carrega o peso ideológico contido em seu sufixo amesquinhador. Surgido por volta do século XVII, em dicionários europeus, o termo designava mulheres celibatárias. A palavra spinster (solteirona) foi usada pela primeira vez na Inglaterra, em 1719, com o sentido de "mulher solteira que já passou da idade habitual para se casar" (Watt, 1996, p. 128). Nesse mesmo período, vivia-se a emergência de certo ideal feminino atrelado ao casamento e à maternidade "como elementos definidores do 'ser mulher' enquanto lócus ideal do feminino" e 
definidores da "verdadeira mulher" (Swain, 2000, p. 54), restando às celibatárias o estereótipo de mulheres infelizes por sua incompletude, ou seja, pela ausência do casamento e da maternidade, de modo que "para a sociedade, a mulher solteira é uma mulher mutilada. É como se, por si só, ela não existisse" (Amorim, 1991, p. 15).

Em contrapartida a esse pensamento, Bastinha tira da manga outro cordel, a história de Dona Flor e seus namorados, de 1998. É narrada, em terceira pessoa, a história amorosa de Florzinha, uma bela moça que tem vários namorados. Sobre o comportamento de Florzinha, temos três perspectivas, a da narradora, a da própria Florzinha e a de seu pai. O pai posiciona-se como o guardião da moral da filha e lhe aconselha a decência para que garanta futuro casamento:

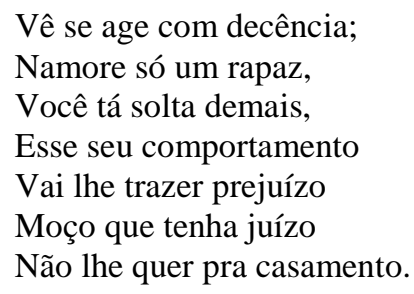

A voz do pai é eco da ideologia patriarcal de resguardo, contenção e doutrinamento. Por patriarcado entende-se

\begin{abstract}
um conjunto de relações sociais entre os homens, que têm uma base material, e que sendo hierárquicas, estabelecem uma interdependência e solidariedade entre eles [...] que lhes permite dominar as mulheres; a base material sobre a que se assenta seria o controle dos homens sobre a força de trabalho feminina e sobre os recursos que as mulheres produzem, e o controle sobre sua sexualidade (Serrano apud Santos, 2004, p. 87).
\end{abstract}

A limitação do conceito de patriarcado frente à imensa diversidade cultural e a outras formas de relação, que não pautadas exclusivamente pela dominação masculina e pela obediência feminina, é posta em questão no cordel, pois, apesar de o pai de Florzinha reiterar o discurso patriarcal com toda sua força repressora, Florzinha não concorda com pai. A categoria gênero, definida, nos termos de Teresa de Lauretis, como "a sua própria construção" (Lauretis, 1994, p. 209), que ocorre por meio de várias "tecnologias do gênero", entre quais estão a literatura, as artes plásticas, a mídia etc., pode dar conta dessa problemática de forma melhor que o conceito de patriarcado, uma vez que, entendendo o gênero nas relações, atribui-se a homens e mulheres o poder tanto de oprimir quanto de resistir. 
A partir do caráter relacional das relações de gênero, podemos compreender o jogo estabelecido por Florzinha para resistir à opressão de seu pai. A quantidade de namorados é explicada por ela, por meio do deboche, como sendo uma tentativa de encontrar o melhor pretendente para o casamento, jogando, assim, com o desejo do pai e o seu próprio desejo.

\author{
Assim se justificava \\ E a desculpa que dava \\ É que queria acertar \\ Daí a experiência \\ Se feita com competência \\ $\mathrm{O}$ melhor ia encontrar.
}

Buscando seu benefício próprio, indolentemente insubordinando-se ao seu pai, Florzinha desvia-se da pretensa autoridade paterna mediante a dissimulação que, se não é um enfrentamento direto à dominação patriarcal, ao menos consegue se desviar dela e, subterraneamente, questioná-la. E é o deboche de Flor que lhe aparece como alternativa para quebrar a rigidez de seu pai.

Entre a opinião do pai e a da filha namoradeira há a posição da narradora. Não querendo julgar, mas já julgando, coloca-se contrária à Florzinha e a favor de seu pai, pois postula o ideal da preservação feminina.

\footnotetext{
A flor que cedo se aflora

Perde o viço e não demora

Do dom da vida fluir,

Perde logo o seu perfume

Ficando a dor e o queixume

Do espinho sempre a ferir.
}

Aproximando os dois cordéis de Bastinha - Prece de uma solteirona e Dona Flor e seus namorados -, podemos perceber a existência autorizada de apenas duas escolhas às mulheres adultas: a vida de casada ou a vida de solteirona. A primeira repleta de felicidade, e a segunda de sofrimento. Uma possível terceira opção, apontada pela personagem Florzinha, é colocada como indecente e provisória, de modo que não cabe às mulheres permanecerem, por muito tempo, solteiras.

A respeito das possibilidades de existência e de constituição do sujeito, Foucault define dois níveis de fenômenos. O primeiro, denominado de "código moral", que designa "um conjunto de valores e regras de ação propostas aos indivíduos e aos grupos por intermédio de aparelhos prescritivos diversos, como 
podem ser a família, as instituições educativas, as igrejas etc.” (Foucault, 1990, p. 27). O segundo, cunhado de "moralidade dos comportamentos", refere-se "à maneira que, e com que margens de variação ou de transgressão, os indivíduos ou os grupos se conduzem em referência a um sistema prescritivo que é explícita ou implicitamente dado em sua cultura, e do qual eles têm uma consciência mais ou menos clara" (Foucault, 1990, p. 27).

Os cordéis de Bastinha são sintomáticos em relação ao processo de constituição do sujeito feminino, suas personagens estão imersas em um código moral que prescreve a cartilha patriarcal de comportamento. Todavia, suas personagens desviantes afastam-se da moralidade de comportamento proposta, de forma consentida ou às avessas, apontando-nos outras maneiras de subjetivação.

Contudo, não podemos nos furtar ao fato de que o que está subjacente às narrativas é o único destino aceitável a todas as mulheres: o casamento. Ao passo que a personagem-narradora de As preces de uma solteirona é uma solteirona que se proíbe de exercer sua sexualidade - pois se institui o casamento como a legítima forma de se obter sexo -, a personagem Florzinha vive sua sexualidade, mas é vista com maus olhos por aqueles que a rodeiam, como seu pai e a narradora de sua história.

Essas situações marginais, de solteirona e de solteira, são por si só questionadoras do casamento como caminho único das mulheres. Mas, ao mesmo tempo, pelo estigma de incompletude que carregam nas narrativas, insinuam e cobram das mulheres que se casem, a fim de que cumpram o que foi instituído social e hegemonicamente. A sociedade patriarcal esboçada nesses textos toma as personagens de Bastinha como mulheres desviantes (Dauphin, 1992) e fracassadas socialmente (Bassanezi, 2004), já que fogem do padrão de comportamento estabelecido pela sociedade criada nos cordéis.

Florzinha e, às avessas, a solteirona de Preces de uma solteirona, desviam-se da representação hegemônica de gênero para as mulheres. Elas são o que Teresa de Lauretis chama de eccentric subject, ou seja, um "ponto de vista" ou uma "posição discursiva" fora das determinações hegemônicas que aponta para possibilidades de resistência (Lauretis, 1990, p. 139). Apesar de os cordéis reafirmarem pelas exceções o hegemônico, suas personagens também sinalizam a vida de celibatária ou de solteira como formas de resistência e subjetivação das mulheres. 
De certa forma, as personagens de Bastinha estão entre a norma e a exceção das matrizes da inteligibilidade de gênero. Podemos entender gêneros inteligíveis como "aqueles que, em certo sentido, instituem e mantêm relações de coerência e continuidade entre sexo, gênero, prática social e desejo" (Butler, 1998, p. 38). Assim, Florzinha e a solteirona estão inseridas nesta matriz que, se por um lado as aprisionam, por outro lado também apontam outras formas de vivência e de superação desse mesmo aprisionamento.

Os cordéis de Bastinha, ao mesmo tempo em que apresentam princípios doutrinadores, também dão a ver uma possibilidade de leitura alternativa, e feminista, visto que a preocupação com a manutenção de uma história para as mulheres acaba por contar outras histórias. A estratégia discursiva do deboche, como forma de desestabilizar, é empregada como uma maneira de resistir a essa única saída, o casamento, mesmo que por meio de "formas cotidianas de resistência" (Scott, 2011), e, assim, poder confrontar, de algum modo, uma realidade e ir além de certas e impostas condições de existência. Enquanto os cordéis de Bastinha encenam a repressão sofrida por sociedades patriarcais, a obra de Salete Maria da Silva, a qual veremos em seguida, nos apresenta a necessidade de se libertar dessa repressão.

\section{0 impossível no cordel de Salete Maria da Silva}

Salete Maria da Silva nasceu em sete de março de 1970, em São Paulo, tendo por pais a dona de casa Raimunda Alexandre da Silva e o pedreiro Hamilton José da Silva, e viveu em Juazeiro do Norte (Ceará), da década de 1980 até 2013, quando passou a morar em Salvador, onde hoje é professora do curso de Bacharelado em Estudos de Gênero e Diversidade da Universidade Federal da Bahia (UFBA), além de advogada. É ativista política, foi militante do Partido Comunista do Brasil (PCdoB) e do Partido da Causa Operária (PCO), por meio do qual concorreu aos pleitos de vereadora (1996), prefeita (2000) e governadora (2007) no estado do Ceará. O cordel entremeia-se à candidatura política de Salete Maria, assim como é entremeado pela política, em uma via de mão dupla. 


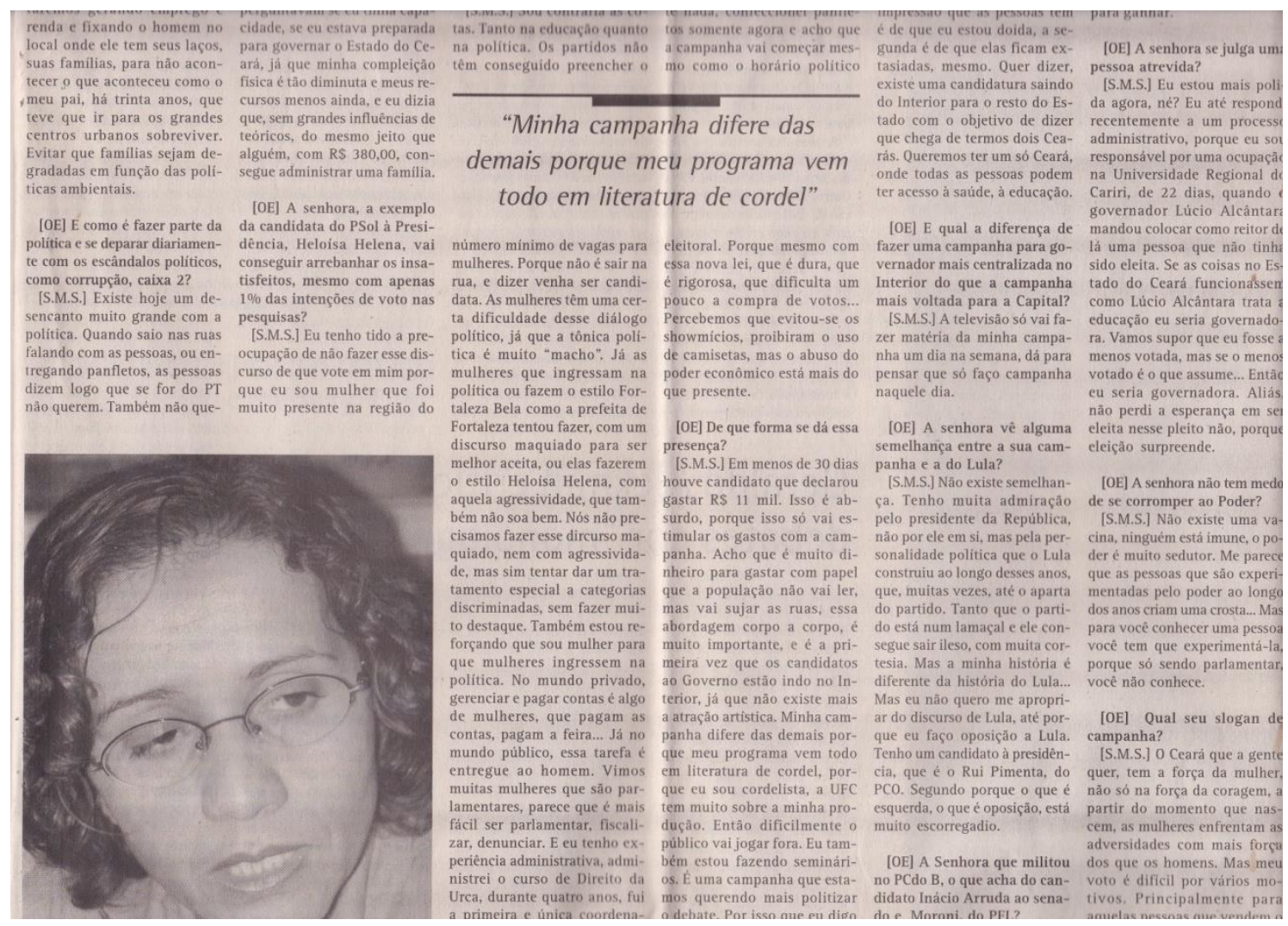

Entrevista concedida ao jornal $O$ Estado de 14 de agosto de 2006, na página 5 da seção política.

Tendo, até o presente momento, publicado setenta e um folhetos, conforme tabela disposta a seguir, por meio de sua poética contundente, a cordelista que fora uma das idealizadoras e fundadoras da Sociedade dos Cordelistas Mauditos, defende suas bandeiras e passeia entre mulheres de vozes e atitudes dissonantes do grande coro social - são donas de seu próprio nariz, lésbicas, transexuais e outras, muitas outras.

\section{Relação de cordéis de Salete Maria da Silva}

20 anos de cordel: tô aqui pra celebrar

A desforra de Bartira

A história de Joca e Juarez

A história de Zé Leitor

A mulher de sete vidas

Agora são outros 500 - Mentira tem perna curta

Assédio moral, diga não!

Assuma o ativismo

Autonomia e respeito

Basta de feminicídio

Carta a Gilvan Luiz

Carta aberta ao reitor no aniversário da URCA

Cidadania, nome de mulher

Coletivo: camaradas

Cordel - Alvará Judicial

Cordel para Sammyra ou mais uma dose de amor

Cordelirando 
Dia do orgulho gay

Dimas, o bom ladrão?

Direitos humanos: isto é fundamental

Do direito de ser gay, ou condenado à homofobia

É hora de dar troco: nem Raimundão, nem CC

Embalando meninas em tempo de violência

Faustino, um vencedor

Feminismo em cordel: como foi que começou?

Guerreiras do Cariri

Habeas bocas, companheiras

Janaína Dutra

Juazeiro faz cem anos e a luta continua

Jus femina, sin frontera

Lesbecause

Lugar de Mulher

Mães de maio: dor e luta

Manifesto pelas mães trabalhadoras

Maria de Araújo e seu lugar na história, ou a beata beat Cult

Maria, Helena.

Meu pai

Minha preta, vem pra marcha

Mulher também faz cordel

Mulher, amor não rima com AIDS

Mulher-cariri, cariri-mulher

Mulher-consciência, nem violência nem opressão

Mulheres (invisíveis) de Juazeiro

Mulheres de axé

Mulheres do cariri, mortes e perseguições

Mulheres fazem

Não ao tráfico de mulheres

Negreestilo

O beijo faz diferença

O caso Eliza Samudio e o machismo total

O grito dos "mau" entendidos

O milagre travesthriller: a história da travesti que (com fé) engravidou

O que é ser mulher?

O que é velhice?

Oração (ao Cuca) e á cultura cariri

Outras pessoas

Para Marcondes

Poema para Orlando

Porque não sou obrigada

Pra vida ser mais bacana (feliz aniversário Gabriel)

Respeitem a presidenta

Salete Maria manda notícias do México em forma de poesia

Todo racista é otário

Três é um real

Um sonho em que o direito combate preconceitos

Urca, 18 de julho

Urca, caso de polícia

V Encontro do Ministério Público no Cariri- Ministério Público e sociedade: perspectivas da cidadania

Vamos para a rua a mil

Violeta: carpinteira da cultura

Visão do STF sobre a lei eleitoral 
A grande influência da cordelista, segundo ela mesma, foi sua avó, Maria José, para quem lia folhetos ao entardecer no sertão. Em seu cordel Cordelirando, de 2001, saúda à sua avó.

$$
\begin{aligned}
& \text { Eu faço cordel porque } \\
& \text { Aprendi a escutar } \\
& \text { E mesmo aprendi a ler } \\
& \text { Vendo vovó recitar } \\
& \text { História de Lampião } \\
& \text { De Padim Ciço Romão } \\
& \text { De João Grilo e Boi-bumbá. }
\end{aligned}
$$

O mundo rural e a influência da cultura popular são entremeados com a vivência com a avó, marcando sua relação com o mundo oral do sertão. O seu primeiro cordel, Desabafo acadêmico matuto, traz essas reminiscências. Publicado em 1994, no jornal $O$ Caldeirão, do Diretório Central dos Estudantes da Universidade Regional do Cariri (URCA) é uma raridade encontrá-lo. Não está nem mesmo no blog da cordelista, por isso foi disposto a seguir. 


\section{Nesabajo Acadêmico Matuto}

Seu menino eu tô doente Tô tirinca da vida

Tô quase que arrependida

De querè me doutorá Já estou pra me daná

Eabaniơná este curso

Pra mode eu me formá

Mais as coisa cúma tá

Me deixa mágua no peito

Este curso de Direito

Só vai me desmantelá

Pois veja o que eu vou contá

Pra mode vanceis sabê

Eque o povo num vê

O que se passa por cá

Aqui pra mode estudá

0 cabra tem que sê santo

Porquanto eu num me espanto

Se Satanás se soltá

Fois a coisa cuma tá

Me deixa mágoa no peito

Este curso de Direito

Só vai me desinantelá

Aqui o cabra aprende

A mentí nem que num quêra

Cumé que eu vou me livrá

Tem dolô pra consentá

0 que já tava direito

Assistente de Prefeito

Professó sem ensiná

Mas querendo sê perfeito

E as coisa cuma lá

Me deixa mágoa no peito

Este Curso de Direito

Só vai me desmantelá
Eu tô estudando a püiso

No meio de "Tanto Besteira"

Promotor e coisa e tá
Nias reunião aqui

Tem doutô que dá cascudo

Pra baixinho ficar mudo

E doutora se calá

Eu sei que pro pau cantá

Só faltou desse tintin

Menino aqui o pantim

E coisa que tá sem jeito

Me deixa mágoa no peito

E eu volto a reiterá

Este curso de Direito

Só vai me desmantelá

Os aluno nessa onda

Não tão nem aí também

Tem professô que num vem

Colega que eu nunca vi

Aula que eu nunca assisti

Assunto que eu nunca sube

E antes que as coisa mude

Pra pió do que está

O jeito é arregaçá

Meu verso coxo matuto

Pois tem dotô, Bicho Bruto

Achando g'eu tô errada

Que num é da minha alçada

Querê ajeitá o pleito

E as mágoa no meu peito

Volta a me incomodá

Este curso de Direito

Só vai me desmantelá

Já dissero que a fraude

Inté pintê puraqui

Tem! cabra de Mauriti

Que num qué acreditá

Fois olhe eu vô contá

No Vestibular tem coisa

Macaco, Soin, Raposa

Querendo Advogá
Deputado "Quase Eleito"

Diz que o troço tá sem jeito

Nem milagre de Prefeito

Faz as coisa se ajeitá

E as mágoa no meu peito

Êta: Curso de Direito

Bonzin de se ajeitá

inté uns colega meu

Metidos a sê Juiz

Alunos vis, aprendiz

Do ofício de calá

Nern Miulihé quer respeitá

Mes no que teja Gestante

Inda se diz estudante

Aspirante de Dotô

Os seus nome eu num dô

Pru que num sô Dedoduro

Nem fico em cima do muro

Como íaz Cordenadora

Que só fica na tisora

E num pode mais dá jeito

E essa mágoa no meu peito

Parece que quer saltá

Eta: Curso de Direito

Bonzin de se Indireitá

Inté aqui eu falei

Das coisa que tão errada

Num falei das ajeitada

Nem das pequena exceção

Meu fii num se avexe náo

Pro que o que é certo

Eu digo

Tem professo que é amigo

Que trabaia direitin

Que cumpre cum seu devê

E contribui com a história

Mais vige Nossa Senhora

Como esse povo é poquin
Movimento estudantil

A gente caça e num vê

- Os cabra pode é morré

Sem tê um ensino bom

As menina de batom

Em carro vido fumé

Os cabra querendo sé

Dotôres só pelo Dom

De Paletó é Garcom

De Beca é pura Meleca

Eu sou levada da breca

E alguém vai se daná

Mais vancêis pode é falá

$O$ poesia minuta

Que baixaria matuta

Contudo eu nem escuto

$\mathrm{Na}$ zoada da Mutuca

Prá mode finalizá

Quero iová o Direito

Do cabra pudé falá

Do que num está perfeito

Usando seu linguajá

E cada qual do seu jeito

Que é prá mode melhorá

E a gente frequentá

Uma escola de respeito

Pois as coisa cuma tá

Me causa mágoa no peito

E eu vốto reiterá

Nesse meu verso mal feito

Que esse curso de Direito

Tá bom de se INDIREITÁ

Salete Maria

VIII Período de Direito

Cordel Desabafo Acadêmico Matuto de Salete Maria da Silva publicado em 1994 no O Caldeirão.

É apenas em Desabafo Acadêmico Matuto que Salete Maria da Silva emprega

uma narradora matuta, depois assume sua própria voz dentro de sua obra, mantendo

apenas sua dicção militante. 


\section{Militância poética}

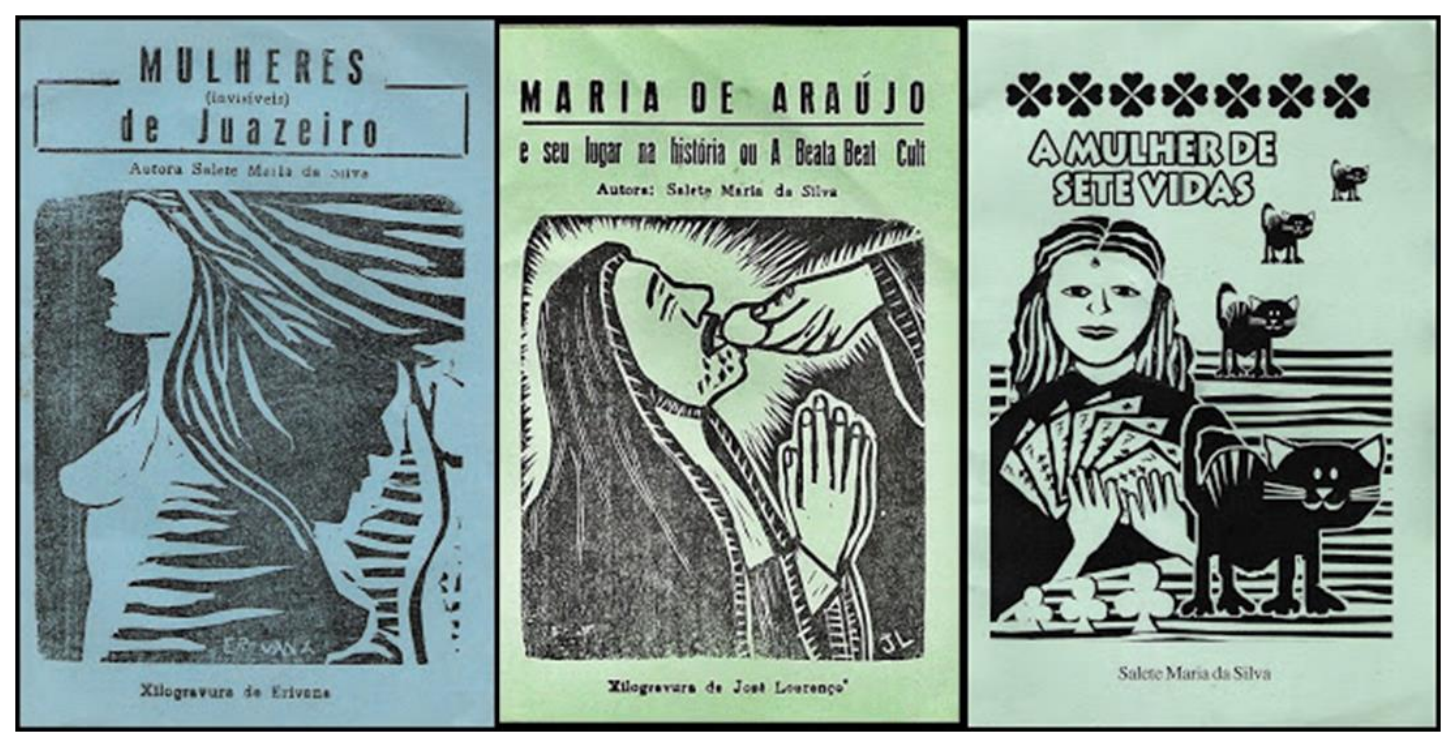

Capas de cordéis de Salete Maria da Silva

O posicionamento autoral de Salete Maria da Silva pode ser analisado mediante o conceito de artevismo, trazido do mundo da cultura urbana, pela própria cordelista, para caracterizar sua obra. Artevismo designa, de modo geral, o entrelaçamento entre arte e ativismo político; no caso da cordelista, mediante o cordel, entre poesia e agenda política. O conceito de artevismo, pela própria sugestão do neologismo, refere-se à arte que se constrói em ativismo e ao ativismo que se constrói pela arte. Seu cordel dá prosseguimento à tradição cordelística, tanto como espaço de criação poética quanto como espaço de divulgação jornalística, e redimensiona essa poética, como um espaço de luta política, em especial feminista. A cordelista afirma-se como sujeito do feminismo comprometido com a luta social. O que para alguns escritores e escritoras é uma afirmação da qual atualmente se foge "minha obra tem por objetivo, escrevo com a finalidade de", - para Salete Maria da Silva é um mote construído, afirmado e divulgado.

Ao longo da história da literatura, houve momentos em que a função social da obra ganha relevância, a exemplo dos construtivistas russos. No âmbito feminista, são muitas as artistas que também defendem esse estro. A preponderância da função social é considerada, contudo, por parte significativa da crítica, como fator de diminuição da obra. No Brasil, muitos foram os artistas acusados de produzir obras menores em que havia o predomínio do social em detrimento do estético, a exemplo de Carlos Drummond de Andrade, considerado o nosso poeta nacional, que sofreu essa acusação com a publicação de A rosa do povo. 
Uma das razões para o julgamento dessas obras como menores advém da subalternização da experiência em face do artifício, da desvalorização ao que se alinha à natureza e distingue-se da cultura. Esses movimentos foram pensados pelo teórico espanhol José Ortega y Gasset, em sua obra A desumanização da arte (1983), em que o autor defende a arte que se afasta da experiência, ou seja, uma arte desumanizada, e acusa uma arte contaminada pelo e em prol da experiência social. Como ressalta Eagleton,

poucas palavras são mais ofensivas aos ouvidos literários do que "utilidade", que evoca objetos de uso como grampos de papel e secadores de cabelo. A oposição romântica à ideologia utilitária fez de "uso" uma palavra impossível de ser usada: para os estetas, a glória da arte é a sua total inutilidade (Eagleton, 2006, p. 314).

É da arte contaminada que a cordelista se ocupa, empregando, ainda, teorias, paradigmas e concepções marxistas e feministas. Ao explicitar, abertamente, como defende Rita Terezinha Schmidt (1994, p. 28), a vinculação "entre interesse e conhecimento", a crítica feminista flagra o interesse, ou o comprometimento, que antecede o conhecimento e que é responsável pela formação de uma epistemologia e dos valores por ela criados, bem como questiona a universalidade de uma única definição das coisas:

\footnotetext{
O interesse é constitutivo do conhecimento. Isso porque os interesses dos que produzem conhecimento - os indivíduos, as comunidades científicas, os pensadores da cultura - determinam a forma do conhecimento. Poderíamos então dizer que não há conhecimento desinteressado (Schmidt, 1997, p. 143).
}

A constatação de que não há conhecimento desinteressado permitiu evidenciar justamente que a suposição de que a literatura é universal, autônoma e isolada de fenômenos sociais não passa do escamoteamento do interesse, e mesmo de alienação da cultura e da literatura da sociedade. O conceito de artevismo, que perpassa toda a obra da cordelista é a autodeclaração do interesse da arte militante e política de Salete Maria. O cordel comemorativo de sua carreira, denominado de 20 anos de cordel: tô aqui pra celebrar, publicado em 2014, é o que traz as ideias que sustentam esse conceito de maneira mais direta. Abaixo um trecho dessa obra.

Foi lendo para os parentes

Lá pela zona rural

E vendo eles contentes

Com aquele velho jornal

Que trazia as notícias

E expunha as malícias

De playboy a general 
Recitando e divertindo

Família e agregado

Aos poucos eu fui sentindo

Que tinha algo de errado

Todo poeta era homem

Falando de lobisomem

E de príncipe encantado

As histórias tinham reis Soldados e coronéis

Homens que faziam leis

Ou que eram bacharéis

O cabra macho era o tal

Androcentrismo total

E mulher não tinha vez

Foi no meio desse povo

Que fui talhando meu verso

Tecendo algo de novo

Esquisito e controverso

Botei a voz das meninas

Para quebrar a rotina

Dos machos desse universo

Aprimorei minha rima

Lendo outros cordelistas

Garimpei ouro na mina

Enquanto seguia pistas

Não gostei dos preconceitos

Rimei em prol do respeito

Às bandeiras feministas

Botei minha ideologia

Defendi o comunismo

Fiz cartas de alforria

Ironizei o cinismo

Das regras capitalistas

E dos falsos moralistas

Com seus velhos catecismos

Juntei com outros Mauditos

E o caldo engrossou

Meus poetas favoritos

Não deu outra, fiz amor

Criamos um movimento

Lançamos rimas ao vento

E muita coisa mudou

Fiz versos sobre viados

Travestis e prostitutas

Bêbados e tatuados

Velhos e filhos da puta

Valorizei lesbianas

Politizando as xanas

E mostrando suas lutas

Ao mesmo tempo em que afirma a tradição de criação poética do cordel aprendizado no ambiente familiar rural, por meio da oralidade, com sua avó que não sabia ler ou escrever -, a cordelista a questiona, principalmente no que se refere à 
temática absolutamente voltada a questões e valores masculinos e a ideologias moralistas, capitalistas, homofóbicas.

Ao mesmo tempo em que Salete Maria da Silva se alinha à tradição do cordel, vendo, desde sempre, a importância tanto poética quanto política do cordel na vida dos sertanejos e dando prosseguimento ao seu uso como jornal do povo, dele se afasta quanto às temáticas tradicionais tratadas. Ela se alinha e desalinha da tradição do cordel porque, mesmo realizando o que se denomina de cordéis midiatizados conceito desenvolvido pela pesquisadora Simone Mendes -, ou seja, cordéis "que se constituem na fronteira entre o domínio "literário"61 e o domínio midiático", com essa tradição não compartilha temáticas.

O artevismo da cordelista alinha-se a uma importante tradição literária de militância política, que se fundamenta, em grande medida, nos princípios do gênero didático. O cordel vincula-se, ainda, aos demais gêneros literários, apresentando elementos líricos, épicos e dramáticos em muitas de suas realizações, havendo, inclusive, divisões entre os cordéis quanto ao gênero literário a que mais se aproxima. A centralidade do gênero didático na poética do cordel advém do seu tom narrativo, que é de instruir e de ensinar, sendo esse, justamente, o motivo de sua desqualificação no universo literário, já que o didático iria contra o estético, aspecto de valoração do literário, e se ligaria ao moral e ao político.

A história dos gêneros literários parte da divisão feita por Aristóteles entre os gêneros lírico, épico (do qual descende o romance) e dramático, os quais constituem, por excelência, o literário. Alguns teóricos de literatura medieval, como Peter Burke, estabelecem a existência de outro gênero literário, o didático, um meio de criação poética empregado no período medieval e, ainda, cultivado na era barroca, o qual foi rechaçado do âmbito do literário nos períodos posteriores, passando a atrelar-se à literatura de má qualidade, dado objetivar antes ao ensinamento moral e político que à elaboração estética.

O cordel brasileiro, e também aquele produzido em outros lugares do mundo, é uma das poéticas que ainda se utiliza do gênero didático, de seus recursos de criação poética. O que se contrapõe ao tradicional conceito de literatura, que é majoritariamente defendida por escritores(as) e críticos(as) como uma produção que

${ }^{61}$ Simone Mendes $(2011$, p. 24)emprega o termo "literário" entre aspas por defender que "o cordel advém das poéticas da oralidade e não do domínio literário, no sentido moderno do que reconhecemos ou é reconhecido como texto literário". 
objetiva à criação estética em primeiro plano. A exemplo do que postula Afrânio Coutinho (1986, vol. 1, p. 87), de acordo com o qual, "a literatura não visa ao conhecimento, à informação, ao ensinamento". Preocupar-se com o que dizer antes de se preocupar com o como dizer é uma conduta valorada negativamente pelo meio literário, que postula o literário como o esteticamente estabelecido como literário.

O cordel também é julgado, pela maior parte da crítica, como subliteratura, literatura menor, em virtude de sua forte correlação com o didático, a informação e o ensinamento, ou seja, da predominância do o que dizer em detrimento do como dizer, tudo isso, é claro, entendido em termos relativos. Há uma ideia disseminada por parte da crítica literária de que a predominância política, e porque não dizer moral, na produção de literatura consiste em um elemento deslegitimador desse tipo de poética. Parece-me, na verdade, que se o que dizer e o como dizer, ou seja, a temática e o conteúdo de uma obra literária, caracterizem-se como políticos e militantes, haverá uma desvalorização.

Em Manifesto pelas mães trabalhadoras, de 2012, por exemplo, Salete Maria realiza reivindicação política relativa ao âmbito público (poderes políticos) e ao privado (ambiente doméstico), questionando a posição de nossa sociedade em relação ao senso de justiça e igualdade.

\footnotetext{
Vocês todos ficam putos

Com político ladrão

Mas roubam até o sangue

Daquela que faz o pão

$\mathrm{O}$ arroz e a salada

A farofa, a carne assada

E o doce de mamão.
}

No cordel de título A desforra de Bartira, de 2012, são expostas as armadilhas do jogo político da justiça, bem como a organização social que propicia a desigualdade.

\author{
Tô indo para a cadeia \\ Porque furtei um ovinho \\ E porque tenho na veia \\ O sangue do zé povinho \\ Mas se eu fosse uma ministra \\ Que roubasse em sua vista \\ Você daria um jeitinho \\ Me enoja o seu direito \\ Suas leis e seu poder \\ $\mathrm{O}$ seu discurso perfeito \\ Para quem não sabe ler \\ A sua visão de mundo \\ Seu cérebro sujismundo
}




\section{Quero é cuspir em você}

Dos trechos dos cordéis apresentados, depreende-se uma atitude contestadora da realidade e das instâncias de poder, empregando-se o cordel a favor das lutas políticas do cotidiano da população brasileira pobre, assim como em afirmação de uma outra possibilidade de história, ligada à vida das minorias políticas. Em seu folheto Mulher também faz cordel, publicado em 2005 e ganhador do segundo lugar do Prêmio Nacional de Literatura de Cordel do Estado da Bahia do mesmo ano ${ }^{62}$, Salete Maria da Silva rima sobre a problemática da autoria feminina no universo do cordel e, ao contar a história do cordel, reivindica o espaço das mulheres. Logo nos primeiros versos, anuncia ao (à) leitor(a)-ouvinte uma historiografia do folheto de cordel hegemonicamente masculina:

$$
\begin{aligned}
& \text { O folheto de cordel } \\
& \text { Que o povo tanto aprecia } \\
& \text { Do singelo menestrel } \\
& \text { A mais nobre academia } \\
& \text { Do macho foi monopólio } \\
& \text { Do europeu foi espólio } \\
& \text { Do nordestino alforria. }
\end{aligned}
$$

Os elementos que contribuíram para a formação desse monopólio são discutidos ao longo de todo o cordel. Dentre eles está o analfabetismo. Saber ler e escrever, durante muito tempo em nosso país, caracterizou um privilégio de poucos homens e mulheres. Mas às mulheres foi um privilégio ainda mais difícil de conquistar. Permaneciam, em sua maioria, no universo da oralidade. E nesse mundo contavam histórias, contos, fábulas. Cantavam. Nesse ponto, poucos são as estudiosas e os estudiosos que se contrapõem à presença de autoras, mesmo por que elas são autoras de uma narrativa coletiva. Quando se passa à história do folheto impresso de cordel e da autoria individual, a conversa é outra. Muitos afirmam que as mulheres não o escreveram, o que, de certo modo, abalizou a crítica do cordel a excluir as mulheres de sua historiografia - como já discutimos nas Antologias lançadas pela Fundação Casa de Rui Barbosa. A esse respeito a cordelista rima em Mulher também faz cordel.

$$
\begin{aligned}
& \text { Na cantiga de ninar } \\
& \text { Na contação de história } \\
& \text { Tava a negra a rezar } \\
& \text { A velha e sua memória }
\end{aligned}
$$

${ }^{62}$ Em 2006 a cordelista ganhou o terceiro lugar do referido prêmio, com o folheto Mulher de sete vidas. 


$$
\begin{aligned}
& \text { Porém disso não passava } \\
& \text { Nada ela registrava } \\
& \text { Para sua fama e glória } \\
& \text { Muitas vezes era tida } \\
& \text { Como musa inspiradora } \\
& \text { Aquela de cuja vida } \\
& \text { Tinha que ser sofredora } \\
& \text { Era mãe zelosa e pura } \\
& \text { Qual sublime criatura } \\
& \text { Porém não era escritora. }
\end{aligned}
$$

Apesar de as mulheres criarem constantemente poéticas orais, seu acesso ao mundo do papel e à publicação ocorreu de forma diminuta nos inícios do folheto de cordel. Atualmente, contudo, muitas são as mulheres a criarem folhetos de cordéis sobre os mais variados temas e tons. A despeito do véu que cobre os olhos de pesquisadores e pesquisadoras que afirmam a inexistência de mulheres cordelistas, essas narradoras tomam para si o poder da palavra escrita e constroem suas histórias, como os versos anunciam:

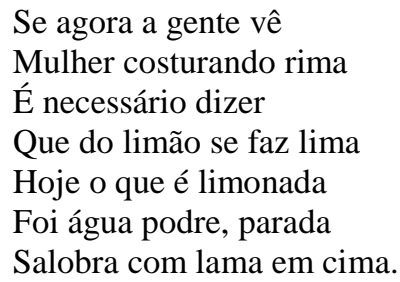

A luta por um lugar ao sol na historiografia é proclamada no cordel. Esta luta é o próprio objetivo dos versos que se apresentam como resposta à pergunta que se teima a fazer a mulheres escritoras: "Vocês existem?". A mesma velha e insistente pergunta que Marina Colasanti discute no ensaio "Por que nos perguntam se existimos" (Colasanti, 1997), e que é respondida em Mulher também faz cordel. Esse cordel-resposta carrega a consciência de que "mais do que objetos de políticas, a comunicação e a cultura constituem hoje um campo primordial de batalha política" (Martin-Barbero, 2003, p. 15) que, neste caso, é travada por Salete Maria da Silva por meio do resgate de suas predecessoras.

Para traçar sua história, canta à primeira cordelista que se tem notícia, Maria das Neves Pimentel.

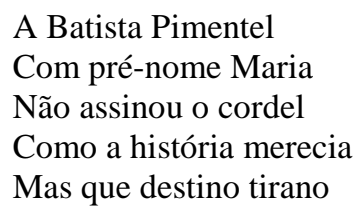




$$
\begin{aligned}
& \text { Um Altino Alagoano } \\
& \text { Era quem subscrevia } \\
& \text { Pseudônimo usou } \\
& \text { Para a obra ser aceita } \\
& \text { O marido orientou: } \\
& \text { 'Assim tudo se ajeita' } \\
& \text { Tava pronto pra vender } \\
& \text { Quem poderia dizer } \\
& \text { Ser o autor a sujeita? }
\end{aligned}
$$

Atrás de sua história, a cordelista caminha pelo tempo, passando de Maria das Neves Pimentel a outras importantes cordelistas que prepararam seu caminho. Salete Maria da Silva reivindica ancestralidade diversa à tradição literária e cordelística hegemônicas. Nas brenhas de sua narrativa, como afirmam Sandra M. Gilbert e Susan Gubar,

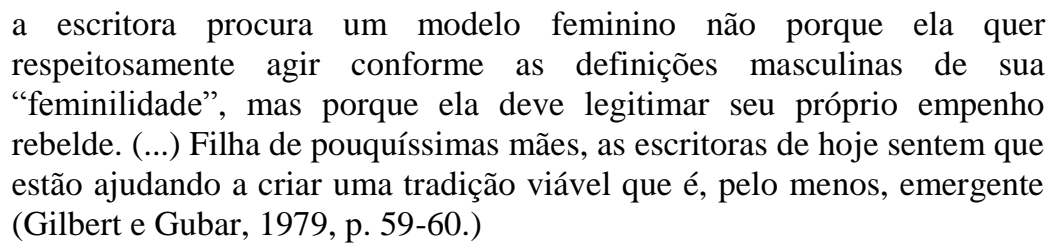
respeitosamente agir conforme as definições masculinas de sua "feminilidade", mas porque ela deve legitimar seu próprio empenho rebelde. (...) Filha de pouquíssimas mães, as escritoras de hoje sentem que estão ajudando a criar uma tradição viável que é, pelo menos, emergente (Gilbert e Gubar, 1979, p. 59-60.)

E assim faz Salete Maria. Por meio de seu cordel, panfleto, jornal e manifesto, a cordelista propaga a sua voz e a voz das que a antecederam. Mais que dar eco à produção dessas mulheres, a autora reivindica a história que está sendo permanentemente construída.

$$
\begin{aligned}
& \text { Em todo nosso Brasil } \\
& \text { Mulheres versejam bem } \\
& \text { Muito verso se pariu } \\
& \text { Não se exclui ninguém } \\
& \text { Tem rima a dar com o pau } \\
& \text { Acho que me expressei mal } \\
& \text { Pois com a vagina também. }
\end{aligned}
$$

Com humor e ironia a cordelista dá seu recado. Anunciando um novo momento da produção literária dessas autoras que hoje escrevem em grande número e com muita qualidade. As afirmações da cordelista sobre a existência e a resistência de mulheres cordelistas fazem parte de um movimento de enfrentamento de uma tradição e de uma história, pois, como afirma Rita Terezinha Schmidt, "é preciso registrar que nós, mulheres, enfrentamos o paradigma de uma longa tradição cultural" (Schmidt, 1994, p. 25), que sabemos que deve ser questionada.

Mas sabemos que nem sempre foi assim. Um dos grandes entraves que as cordelistas encontraram foi o da divulgação de seu trabalho. O cordel foi arte de 
poetas nômades que atravessavam cidades e estados espalhando seus versos. Como as mulheres circunscritas ao ambiente doméstico poderiam desbravar as ruas? Simplesmente não o fizeram. Sedentárias em seus lares, só depois de muitas águas rolarem conquistaram seu espaço. As primeiras cordelistas que assinaram seus cordéis, assim como as cantadoras, repentistas e emboladoras de coco, iam ao calcanho pelo mundo afora acompanhadas de seus maridos e pais, pois, como a cordelista nos relata, "era um grande defeito, mulher sem eira nem beira".

Salete Maria e as cordelistas contemporâneas já não padecem do mesmo constrangimento. São mulheres, escolarizadas em sua maioria, e donas de seu próprio corpo, e não só de seu nariz. Contudo, é importante destacar que Salete Maria da Silva não é a regra entre as autoras de cordel, é exceção. Salete Maria é cordelista maudita. Embora tenha um pé na tradição - a utilização do cordel como gênero literário -, ela ressignifica essa tradição com outros valores, crenças e visões de mundo. O cordel, conhecido como um gênero literário carregado de valores machistas, patriarcais e preconceituosos, na voz e nas mãos de Salete Maria da Silva versa sobre outras histórias. A cordelista anuncia a vez e a voz de grupos inaudíveis até então no universo do cordel. Ela não narra uma suposta mulher sertaneja sofredora e resignada como seus parceiros de tradição. As vozes agora são de mulheres agentes, com diferentes espaços no mundo, com diversas orientações sexuais.

A cordelista se preocupa com aquilo que a tradição do cordel dispensou. Para dar vida nova à tradição, ela reinventa as histórias não só dos tradicionais cordéis - como em seu folheto, feito em parceria com Fanka Santos, Dimas, o bom ladrão?, publicado em 2014 -, mas também a ideologia subjacente a essas narrativas. Ao invés de valores tradicionais, como o casamento heterossexual convencional, o que avulta em seus versos é a união homoafetiva entre Maria e Helena, em seu cordel homônimo, no qual verseja sobre o amor de Maria, agricultora, e Helena, boiadeira e escultora. Somam-se a esses cordéis muitos outros títulos que anunciam a diversidade sexual e outras diversidades que a cordelista preocupa-se em defender contra a reprodução e a manutenção de mecanismos opressores, como a vinculação de estereótipos nas representações que os cordéis produzem. Em sua obra ficam claras as implicações que as representações trazem à vida concreta das pessoas, guiando suas ações e movimentando seus conflitos. 
O que possibilita, de alguma forma, à cordelista inovar e hibridizar valores e tradições é o trânsito de Salete Maria entre diferentes culturas, a cultura oral e popular e a cultura escrita. Pertencente à elite intelectual, a cordelista participa das duas culturas, como ressalta Peter Burke em relação à Europa na Idade Moderna, quando a elite geralmente participava das culturas do povo (Burke, 1989, p. 17). A cisão entre as duas culturas transforma-se nos versos da cordelista em hibridismo de tradições e valores.

Entretanto, se nos estudos literários, "a negação da legitimidade cultural da mulher como sujeito do discurso exercendo funções de significações e representações foi, no contexto da literatura brasileira, uma realidade que perdura até mais ou menos, a década de 1970" (Schmidt, 1995, p. 183), para o caso do cordel, essa situação se sustentou por mais tempo, havendo muito recentemente a projeção de diversas mulheres cordelistas no mundo cordel.

Salete Maria da Silva insere-se nesse contexto não apenas compondo seus cordéis, mas também militando nesse universo. $\mathrm{O}$ artevismo volta-se ao questionamento, desmonte e intervenção do mundo do cordel e de nossa sociedade em sentido amplo, buscando promover a "mútua implicação" (Viveiros de Castro, 2002, p. 119) de tradições discursivas (literatura, cordel, jornal), tanto em termos formais quanto em termos conceituais, assim como a mútua implicação de modos de existência, haja vista que em sua obra se apresentam personagens de diversos estratos sociais, cores, orientações sexuais, até mesmo personagens que buscam transgredir o que se tem como realidade.

\section{Projeção política}

No cordel $O$ milagre travesthriller: a história da travesti que (com fé) engravidou, de 2010, a cordelista propõe o alargamento de uma realidade opressora, por meio do milagre do discurso - a criação de outras realidades, sejam elas possíveis ou impossíveis.

A frase "Creemos en la utopía porque la realidad nos parece imposible" sintetiza o mote de "O milage travesthriller", tendo sido proferida pela primeira vez durante os protestos que aconteceram em Santiago, no Chile, no dia 11 de abril de 2013, nos quais mais de cem mil pessoas, em sua maioria estudantes, reivindicaram uma educação pública, gratuita e de qualidade. Desde então, essa afirmação pode ser 
lida em diversos muros e manifestações populares de inúmeras cidades espelhadas pela América Latina.
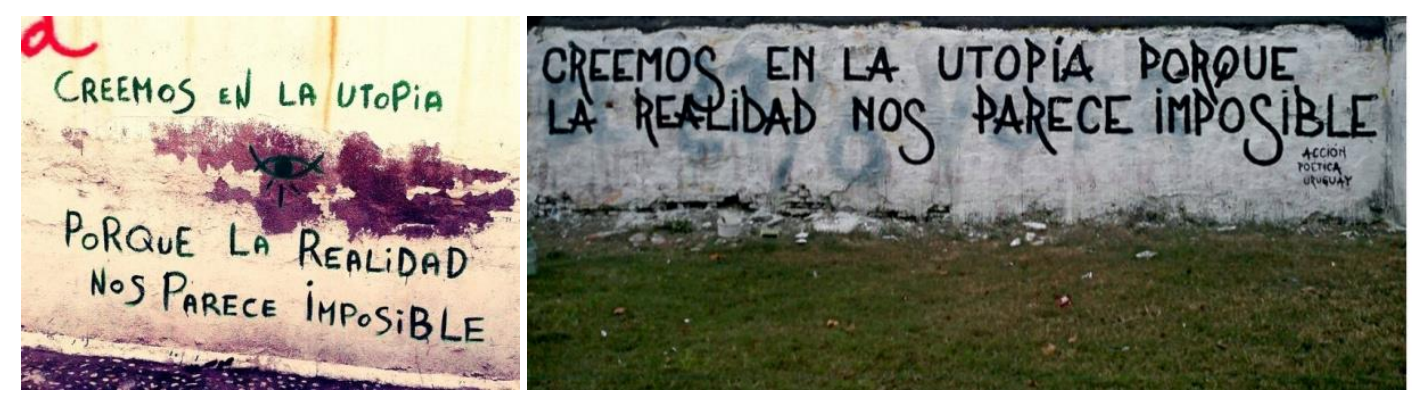

Muros pichados com a frase "Creemos em la utopía porque la realid nos parece imposible" Fonte: Google Images ${ }^{63}$

A inversão semântica em que se assenta o significado desse pensamento, a utopia (impossível) seria o possível, e a realidade (possível) seria o impossível, questiona a legitimidade do que tradicionalmente se entende por realidade e por utopia, com a finalidade de propor um ideal de acordo com o qual a crença em uma utopia substitui a possibilidade de convivência, e por que não dizer conivência, com determinada realidade, supostamente impossível de ser vivida pelos que a questionam.

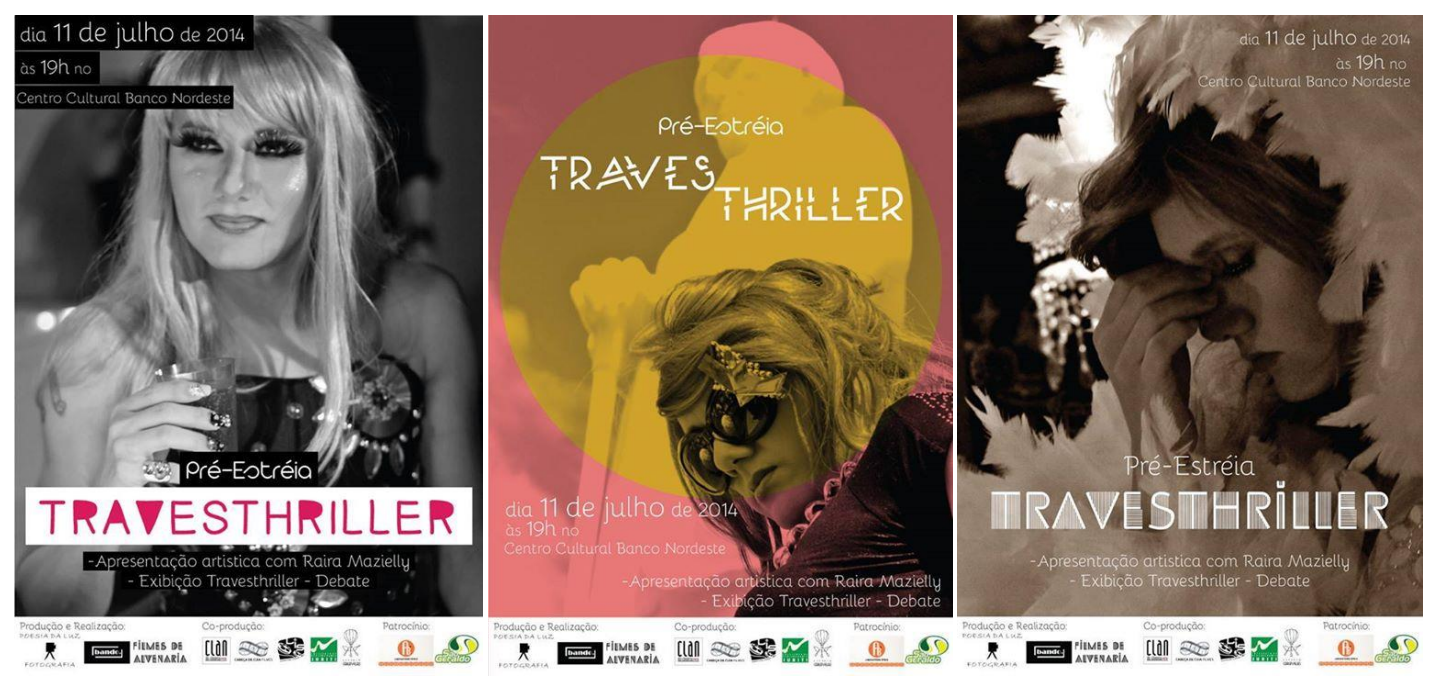

Cartazes de divulgação da pré-estréia do filme.

Fonte: Página do filme Travesthriller no Facebook ${ }^{64}$.

63

https://www.google.com.br/search?q=creemos+en+la+utopia+porque+la+realidad+nos+parece+impos ible \&biw $=1280 \& b i h=699 \&$ tbm $=$ isch $\&$ tbo $=u \& s o u r c e=u n i v \& s a=X \& e i=S J x 4$ VLzsMY_LsASTtYKwA w\&ved=0CB8QsAQ. Acesso em: 2 out. 2014.

${ }^{64}$ Disponível em: <https://www.facebook.com/Travesthriller?fref=ts〉. Acesso em: 2 out. 2014. 
Nesse filme-cordel, que inspirou a criação do curta-metragem Travesthriller, narram-se as gravações de um curta-metragem de suspense cujo argumento consiste na saga da travesti Shirley Dayanna para engravidar. A realidade criada comporta uma travesti que menstrua e clama a Deus uma ajuda, fazendo-lhe orações e promessas.

\author{
Subindo a Serra do Horto \\ Ao som do 'baby pirei' \\ Com seu olhar absorto \\ Curtindo seu happy day \\ Ao lado da comitiva \\ Desfila ela, a diva \\ Orgulho da causa gay \\ De baby-look brilhosa \\ E mini-saia rendada \\ Com sua bota estilosa \\ E a cabeleira dourada \\ Beijando o seu amor \\ Ela entoa um louvor \\ No meio da romeirada \\ Parando nas Estações \\ E agradecendo com fé \\ Balbuciando orações \\ Cumprimentando Seu Zé \\ Jogando beijos no ar \\ Ela acena sem parar \\ Pra bicha, home e muié \\ O filme é encenado \\ Nas ruas de Juá City \\ O povo tá encantado \\ Com o tal enredo beat \\ O roteiro é a história \\ Da neta de Dona Glória \\ E filha de Idelzuíte
}

Trata-se duma promessa Que Shirley Dayanna fez Assim a cena começa

Em Dois Mil e Dezesseis

O Milagre Travesthriller

É dirigido por Muller

E fala de gravidez.

Shirley Dayanna, no intuito de engravidar, acessa diversas instâncias: faz promessa a Nossa Senhora da Conceição, clama a Deus, procura um advogado a fim de que recorra à Justiça dos homens a seu favor, vai a um grupo de apoio a livre orientação sexual de sua região, a uma benzedeira, consulta a opinião de uma amiga feminista e, por fim, na estante dessa amiga, pega um livro de bruxarias "As Bichas Madres de Aurora", que a ensina a utilizar o poder da mente para conseguir o seu 
feito. E dito e certo, após realizar as bruxarias descritas nesse livro, Shirley Dayanna engravida!

Nesse cordel-filme, são trazidos diversos discursos: o religioso, o institucional, o acadêmico, o militante, o místico. A polifonia de discursos aponta, contudo, sempre para a impossibilidade de efetivação do milagre desejado por Shirley Dayanna. Apenas o discurso ficcional, responsável por aglomerar todos os outros discursos, pode garantir a realização do milagre travesthriller. O uso da pluralidade de discursos serve, entre outras razões, para desestabilizar a pretensa autoridade dos discursos, indicando para as imensas possibilidades que propicia o literário e a limitação dos discursos racionais.

Inspirado declaradamente pelo teatro do absurdo e do insólito de Eugène Ionesco, o cordel, recheado de muito humor e jogando no ventilador críticas a todas essas instâncias discursivas, uma vez que relativiza a efetividade desses discursos na compreensão do desejo de Shirley, coloca-se como um lampejo diante da impossibilidade da realidade, buscando trazer compreensão onde, para os discursos da realidade, há incompreensão e absurdo. Até mesmo sua amiga "feminista entendida" a repreende:

\author{
Shirley, você tá pirada \\ Perdeu a noção de tudo \\ Deixe dessa palhaçada \\ Deus pra você está mudo \\ E o Padre Ciço Romão \\ Não lhe dará atenção \\ Tudo isso é absurdo! \\ Para que engravidar? \\ Nestes tempos pós-modernos! \\ Todas querem abortar! \\ Leia aqui nos meus cadernos! \\ Quando eu penso que vocês \\ São as radicais da vez... \\ Defendem mitos eternos \\ Já que quer ser genitora \\ Porque não faz adoção? \\ Hoje a lei é promissora \\ Basta uma petição... \\ Minha filha, se oriente \\ Seja mulher diferente \\ Deixe de esculhambação.
}

Além desse discurso, há também outros discursos: o de Deus, o de um advogado, o de um militante LGBTT e o de uma benzedeira. Todos são unânimes em afirmar a impossibilidade e o absurdo do intento de Shyrley Dayanna, o qual, no 
entanto, se concretiza na ficção do filme-cordel. O jogo entre realidade (possível) e utopia (impossível) é virado, mesmo que apenas ficcionalmente.

Em um mundo de discursos e pensamentos muitas vezes condenados a perpetuar histórias únicas e generalizantes, reprodutoras de normas universais, a autora propõe-se a não ignorar a possibilidade de a ficção ampliar os sentidos da realidade. O filme-cordel cria um mundo que aceita excessos, exceções, descabidos, conforme as ideias do filósofo Hilan Bensusan, em Excessos e exceções: por uma ontologia sem cabimento, de 2008. Nesse sentido, talvez a ficção pudesse ser compreendida como um espaço de interrogações, inclusões, deslocamentos, associações; de realidades e utopias que alargassem os discursos, o mundo e os pensamentos.

A proposta utópica, porque irrealizável e quimérica, de Travesthriller tanto constrói perspectivas outras no plano discursivo - podendo não passar de mera fantasia literária e intelectual - como pode funcionar como horizonte para um futuro plano da realidade, dando força à ação política, desafiando ao pensamento.

A cordelista coloca-se entre as teorias queer e as essencialistas, sendo, predominante, contudo, uma dicção humanizante para com a protagonista do filmecordel e um tom ironizante em relação aos discursos que a cercam e que não conseguem dar conta das possibilidades da existência. A terra, a vida e a gente de Shirley Dayanna não a acolhem em sua saga de gerar um filho; apenas após a concretização do milagre, elas a congratulam.

\footnotetext{
Assim se deu o milagre

Travesthriller sensual

E cachaça com vinagre

Foi a poção magical

Shirley Dayanna feliz

Foi à missa da matriz

Numa entrada triunfal

Desceu as ruas do centro

E o povo todo aplaudindo

Ela sentia por dentro

$\mathrm{O}$ menino se bulindo

Era sua apoteose

Nem lembrava da neurose

Que antes vinha sentindo

A notícia se espalhou

Como água na ladeira

Shirley mal engravidou

E o boato já na feira

Todo mundo interessado

No novo mito gerado

Nesta terra milagreira
} 
Virou capa de jornal

Da Palmeirinha ao Sudão

Na mídia internacional

Rádio e televisão

Até o Barack Obama

Enviou um telegrama

Festejando a ocasião

O prefeito da cidade

Mandou congratulações

Mais de mil autoridades

Fizeram bajulações

Ouviu-se o bispo dizendo

Que o feito era tremendo

Digno de celebrações
A gravidez mais falada
Desta era milenar
Muita tese elaborada
Tentando tudo explicar
Cafuçu fazendo intriga
Falando mal da amiga
Mas querendo o seu lugar.

O filme-cordel termina com uma visão panorâmica da cidade de Juazeiro do Norte, Ceará, a Juá City de Padim Ciço Romão, havendo a integração do espaço, das pessoas e da protagonista Shirley Dayanne, ressiginificando-se a tradição da poética do folheto de cordel de narrar a terra, a vida e a gente. Outra característica tradicional do folheto de cordel que é ressignificada pela cordelista é o conceito de verdade trabalhado nessa obra.

Segundo a estudiosa Ria Lemaire, os poetas e cantadores da oralidade "reivindicam incessantemente a verdade como característica principal da palavra proferida", apresentando-se como "testemunhas da verdade" (Lemaire, 2011, p. 294), sendo o folheto de cordel "muito mais do que a literatura e muito diferente dela" (Lemaire, 2011, p. 297). À poética de Salete Maria da Silva, contudo, aplica-se apenas em parte essa concepção, visto que, ao passo que a cordelista reivindica as idéias de testemunho, porta-voz, categorias que distinguem essa poética da mera ficção, ela também radicaliza com a própria ficção, fazendo uma ficção insólita e absurda. No Post Script do folheto, diz:

\footnotetext{
As fontes bibliográficas?

É simples, amigo meu...

São as histórias fantásticas

Que a vida me ofereceu

De bêbo, puta e doutor

Beato e embolador

Viado, índio e ateu!
} 
Em Travesthriller, articula-se tanto o essencialismo de gênero como o essencialismo cultural. Assim como a cordelista, ao mesmo tempo, alinha-se e desalinha-se à tradição do folheto de cordel, ela também se aproxima e afasta-se da realidade, construindo um mundo de possibilidades e utopias. Da mesma forma, traça uma perspectiva sobre o conceito de ficção que se distingue do valorado e disseminado pelo campo das letras. Para a autora, a ficção cordelística relaciona-se diretamente à poesia e à política, sendo uma produção que visa ao ativismo político. A dicção militante, entremeada por muito humor e ironia, é posta em defesa dos direitos de minorias, configurando-se como forma de resistência discursiva e teórica.

As obras de Salete Maria da Silva e Bastinha participam da ampla circulação da literatura de viés marginal, periférico e popular que busca atingir diretamente o campo social e literário em seus valores hierárquicos e coloniais, bem como participar e construir uma outra história literária. Os cordéis de Salete Maria, especificamente, funcionam como panfletos de sua militância na arte e no mundo, valorizando o discurso como forma de expor e reivindicar demandas e intervir na historiografia literária e do cordel, e até mesmo na história das mulheres, elaborando, ao mesmo tempo, formas locais de resistência discursiva e teórica.

A obra da cordelista apresenta-se como mais uma ação da crítica feminista, que tem se debruçado sobre narrativas silenciadas pela historiografia literária oficial e hegemônica, e ainda reinsere as narrativas da oralidade no movimento atual de se repensar os limites e desafios da literatura. A aproximação do cordel à história literária e da produção de autoras cordelistas à história do cordel e, consequentemente, da história literária, é uma forma de se repensar valores sociais e culturais e questionar as hierarquias discursivas que esses estabelecem.

À revelia da literatura oficial, da canonização institucional do cordel e dos artefatos do mercado editorial hegemônico, a obra dessa cordelista consiste em um espaço de questionamento do literário, do lugar do literário e do seu papel no mundo. Sua posição "obtusa" e à margem tanto do campo literário quanto do campo do cordel tradicional proporcionou a sua obra, contudo, um lugar de fala que incorpora 
exceções em todas as direções e que, consequentemente, possibilita refletir sobre diversos entraves das instâncias hegemônicas e institucionais da literatura, em sentido amplo, e do cordel.

Entretanto, apesar de essa obra permitir o questionamento de estruturas hegemônicas, muitas interdições ainda resistem, sendo esta discussão importante como o lançar de um olhar crítico ainda não concretizado no mundo das letras, mas que possibilita pensar em uma outra forma de conceber o literário. Desconstruindo os regimes de verdade estabelecidos sobre o literário e o cordel, por meio de questionamentos estéticos, epistemológicos e políticos, objetiva-se intervir no campo que se formou e no que se excluiu nesse processo de formação de um canône literário e no próprio canône do cordel, desestabilizando a vontade de ordem e de manutenção imbuídos na vontade de controle por intelectuais e suas instituições discursivas.

Embora a obra da cordelista consubstancie-se à revelia de instâncias oficiais e hegemônicas e usufrua da grande circulação propiciada pela internet, o seu alcance nos círculos tradicionais de estudo da literatura e do cordel ainda é diminuto. A respeito da possibilidade de se veicular discursos, é fundamental considerar que

não se trata apenas da possibilidade de falar - que é contemplada pelo
preceito da liberdade de expressão, incorporado no ordenamento legal de
todos os países ocidentais - mas da possibilidade de "falar com
autoridade", isto é, o reconhecimento social de que o discurso tem valor e,
portanto, merece ser ouvido" (Dalcastagnè, 2012, p. 13).

Atualmente, observa-se um momento de coexistência de opiniões em relação a poéticas marginais, periféricas e populares, havendo posicionamentos que lhes conferem legitimidade e autoridade e outros que não, por diversas razões. O cordel é, ao mesmo tempo, uma poética tradicional, no campo popular e da oralidade, e uma poética não hegemônica, subalternizada e inferiorizada, no campo literário em sentido amplo. Essa imbricação de valores atrelados ao cordel localiza a obra de Bastinha em um ponto de rompimento com o campo literário hegemônico, mas de permanência de um discurso do cânone sobre o cordel, e a obra de Salete Maria em um ponto de dupla ruptura.

O rompimento com a tradição cordelística se dá por meio de seu artevismo, em que a cordelista vai na contramão do discurso historiográfico que fixou uma ideologia imóvel, sólida e inerte à tradição do folheto de cordel, conforme as ideias difundidas pelos estudos da Fundação Casa de Rui Barbosa, pelo trabalho do estudioso francês Raymond Cantel, pelas pesquisas de Átila Almeida e José Alves 
Sobrinho, que deram origem ao Dicionário bio-biográfico de repentistas e poetas de bancada e pelo cânone sedimentado pela Coleção Biblioteca de Cordel. O verso livre e as temáticas libertárias encontrados na poética da cordelista desatam com a tradição do cordel, bem como o fato de tratar-se de uma mulher militante e intelectual escrevendo cordel.

Já sua ruptura com a tradição literária hegemônica ocorre em razão de a historiografia literária brasileira restringir-se a gêneros literários advindos de uma elite intelectual e cultural, sob a ideia de construir uma "grande" literatura e que, apesar da hibridização e dialética entre o local e o universal, o erudito e o popular, compõe-se de valores formais, estéticos e temáticos de uma elite intelectual e mesmo política e econômica.

O cordel de Salete Maria da Silva se insere em um contexto mais amplo de articulação discursiva de direitos de minorias sociais, políticas, econômicas, vinculando-se no mundo das Letras a uma discussão já feita há algum tempo a respeito da legitimidade e visibilidade das vozes periféricas, subalternas e populares no campo de produção hegemônico. A publicação por si só de uma poética contrahegemônica não garante o estabelecimento de um espaço para ela no campo um tanto quanto predeterminado das letras. A publicação via internet não assegura visibilidade, havendo uma série de fatores que interferem na conquista de um lugar ao sol por uma obra e escritora.

Os estudos subalternos - corrente teórica indiana liderada por Renajit Guha, a partir do ano de 1980 - problematizam a questão da visibilidade das vozes proferidas a partir de lugares de fala não hegemônicos, ou seja, subalternos. Gayatri Spivak (2003), em diálogo com os estudos subalternos, introduziu um importante impasse, a partir da noção de subalternidade, que está contido na seguinte indagação: "Pode o subalterno falar?". Segundo a estudiosa, em razão da centralidade da voz que ecoa de pensamentos hegemônicos e da subalternidade das outras vozes, o subalterno não pode, e nunca pôde, falar, pois, a partir do momento em que ele tem acesso à voz, já saiu da posição de subalternidade e não representa mais a voz que um dia possuiu.

Ao contrário de Spivak, a estudiosa feminista Andrea Nye (1995) defende que o mero início da movência dos discursos feministas em direção à articulação de uma voz (a entrevoz) consiste em uma forma de abalar as estruturas vigentes que impedem o estabelecimento dessa voz feminista, de modo que a articulação de um discurso já é capaz de interferir no discurso hegemônico. 
Hugo Achugar (2006), por sua vez, pensando acerca do lugar de fala do discurso subalterno latino-americano, cria a noção de balbucio teórico, que, ao mesmo tempo em que se distancia da mudez estabelecida por Spivak, também dela se aproxima quando pensa nas dificuldades que o discurso marginal, periférico, subalterno, entre outras possíveis designações, encontra em meio ao monólogo do discurso hegemônico. Achugar vislumbra o balbucio, como "uma forma de resistência que tenta confrontar ou problematizar teorizações originadas no Commonwealth [comunidade das nações] e que se apresentam como universais" (Achugar, 2006, p. 65). Para ele, cabe a esses grupos apenas o balbucio, uma vez que a linguagem e a teoria dos grupos marginalizados devem fugir da formação discursiva produzida pelo discurso unitário, universal e hegemônico, que produz, em si, a exclusão.

A irrealização que Spivak constata nos contextos que analisa contrapõe-se à realização que Nye e Achugar vislumbram. O artevismo de Salete Maria da Silva insere-se justamente nessa realização. Sua obra é a concretização disso, se apresentando como um discurso militante que carrega diversas possibilidades de existir e resistir, bem como de questionar o estabelecido, que está cada vez mais cindido, visto que sua poética contra-hegemônica ocasiona questionamentos e deslocamentos por existir como tal.

A obra da cordelista volta-se muito mais à militância político-social que à político-literária, havendo o embate com as tradições literárias do cordel e da literatura oficial hegemônica em decorrência da pungente dicção militante em prol da luta das minorias políticas. As personagens dessa autora - mulheres, pobres, negros, homossexuais etc. - tornam-se, em seus cordéis, centro, mote, razão da própria escrita, em que a cordelista ao mesmo tempo em que diz do outro, diz sobre si mesma.

Um ponto importante na militância poética e política da autora é a crença de humanização pela arte que fundamenta sua produção, voltada exatamente para esse fim. Sua própria obra estabelece uma definição de humanização mediante a proposição de agendas políticas. Para pensar essa ideia, vamos trazer a definiç̧ão de humanização proposta por Antonio Candido em seu reincidentemente citado texto "Direito à literatura".

Entendo aqui por humanização (já que tenho falado tanto nela) o processo que confirma no homem aqueles traços que reputamos essenciais, com o 
exercício da reflexão, a aquisição do saber, a boa disposição para com o próximo, o afinamento das emoções, a capacidade de penetrar nos problemas da vida, o senso da beleza, a percepção da complexidade do mundo e dos seres, o cultivo do humor. A literatura desenvolve em nós a quota de humanidade na medida em que nos torna mais compreensivos e abertos para a natureza, a sociedade e o semelhante (Candido, 2004, p. $180)$.

A concepção de Candido parece ser compartilhada pela cordelista, que a propõe, contudo, em outros termos, estabelecendo uma agenda de desalienação a seus leitores e leitoras, por meio da exposição de questões ligadas a classismo, racismo, misoginia, homofobia, lesbofobia, transfobia. Lutas decorrentes das bandeiras por visibilidade e inclusão social levantadas pelos grupos alvos desses preconceitos, ou seja, da militância dos feminismos, dos movimentos negros, entre outros.

Um dos pontos fulcrais da obra de Salete Maria da Silva diz respeito às implicações e aos impasses desencadeados pelo hibridismo de tradições culturais e literárias e pela defesa de temáticas oriundas das lutas sociais. Se se fala de elitização do cordel por movimentos como o Armorial de Suassuna; na poética da cordelista pode-se falar em politização do cordel por uma intelectual, ainda que seja da classe popular. Salete Maria representa, no cenário do cordel, uma mudança no perfil dos cordelistas, que mudou seu espaço de residência - estando hoje na cidade -, seu espaço de aprendizado - hoje também localizado nos partidos políticos e nas universidades -; bem como seus leitores, muito parecidos com a própria autora. 


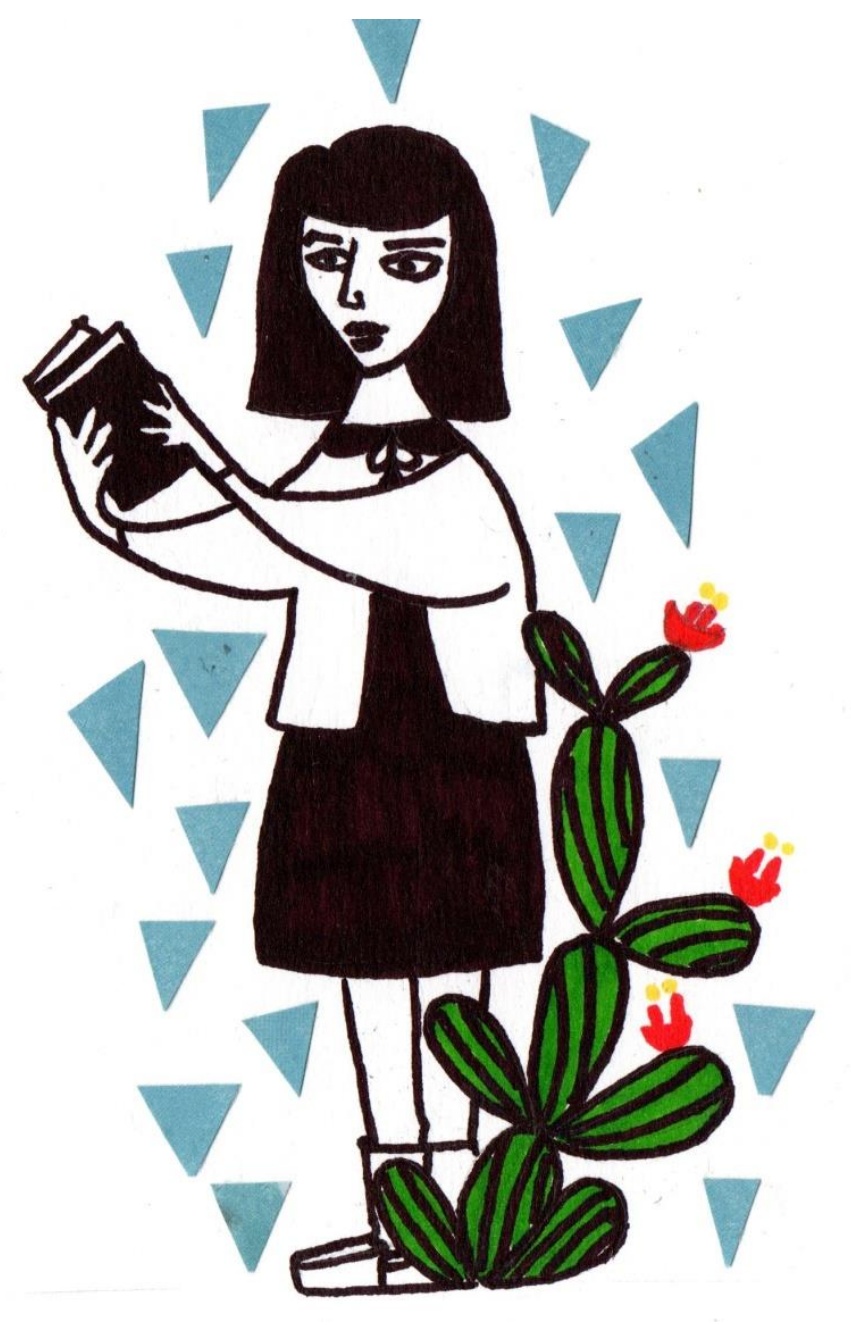

CONSIDERAÇÕES FINAIS

Sob forte chuva: por histórias, teorias e críticas à revelia dos gabinetes 
Enquanto historiadoras feministas, procuramos não o ecoar monótono da repetição do mesmo, mas as vibrações dos acordes múltiplos de uma história possivel, instauradora de diversidade, não da diferença.

tânia navarro swain

Parte significativa da crítica e da historiografia literárias brasileiras, com base em discursos já estabelecidos a respeito da literatura, deu prosseguimento a uma série de prerrogativas, parâmetros, valores e limites relativos ao conceito de literatura. Contudo, a oficialização de uma ideologia crítica e historiográfica não impossibilitou a permanência de constantes produções literárias dissonantes a essa ideologia, embora permanentemente consideradas inferiores na "república mundial das letras" (Casanova, 2002).

Ao olhar o discurso historiográfico buscando-se vestígios dessas poéticas dissonantes, percorrendo-se o que ficou de fora desse discurso e colocando-se no centro de discussão o que foi deixado de fora, observa-se que sempre se perseguiram continuidades, repetições. A exemplo do caso de Domingos Caldas Barbosa, outros escritores foram desprestigiados pela crítica literária em razão de sua poética diferenciar-se dos padrões literários estéticos da então grande literatura e aproximarse de padrões ligados a uma literatura mais popular e de bases orais.

Como pode ser possível haver uma única tradição cultural e literária brasileira, considerando-se nossa extensão territorial, nossa estratificação social, sendo uma característica de nosso país a heterogeneidade cultural? A nossa história colonial e a nossa forma de organização social produzem diferentes espaços. A esse respeito, Aníbal Quijano afirma:

Algumas sociedades são definidas com base em uma ordem de dominação entre grupos sociais portadores de universos culturais diferentes estruturalmente, não só no que se refere aos elementos que as constituem - sua própria organização interna -, mas também em relação a seus valores básicos. Tal, por exemplo, é o caso das sociedades coloniais no território que hoje é a América Latina, das regiões andinas e mesoamericanas, ou de certas sociedades africanas e asiáticas da atualidade. Nesse processo de dominação, as sociedades pré-existentes foram integradas e, como resultado, surgiram novas formações históricosociais cuja característica central, dentro da problemática que aqui nos preocupa, é a heterogeneidade estrutural básica em todas as dimensões e, em particular, na dimensão da cultura (Quijano, 2014, p. 676, tradução nossa). 
A insistente manutenção de um único sistema literário, de uma única história e historiografia literárias, de um único cânone literário, de um único campo literário irradiador de valores, bem como a consequente diminuição, deslegitimação e exclusão de obras dissonantes a esses valores unívocos ignoram nossa própria formação cultural e social. Isso acontece também no âmbito do campo do cordel, em que a vontade de unificação e sedimentação dessa tradição exclui outras possibilidades de produção dessa poética, conforme atesta a estudiosa Ana Maria Galvão:

\begin{abstract}
Impressionei-me, ao me deter com cuidado e acuidade sobre a grande massa de textos sobre literatura de cordel que encontrei nas bibliotecas, nos acervos, nos catálogos das editoras, nos sebos, nas livrarias, com a quantidade do que já foi produzido sobre o tema no Brasil. Impressionoume também a homogeneidade dessa produção quanto a certas afirmações, a certas idéias, a certas maneiras de descrever, de falar sobre o objeto, que eram recorrentes na grande maioria dos textos. Como ocorre em trabalhos similares realizados sobre cultura popular em outros países, a princípio tudo parece já estudado e esclarecido: um estudo repete o outro, complexificando pouco afirmações exaustivamente repetidas (GALVÃO, 2001, p.21).
\end{abstract}

Com a fixação dessa tradição de alimentação do mesmo, tudo o que se distingue é rechaçado, aos moldes do estabelecido em termos de cânone, cujas ideias centrais são seleção e valor, objetivos tidos como intrínsecos ao fazer da crítica. Por cânone, entende-se

um conjunto de textos que passou pelo teste do tempo e que foi
institucionalizado pela educação e pela crítica como clássicos, dentro de
uma tradição, vem a ser o polo irradiador de paradigmas de que e do
como se escreve, do que e como se lê. Tradicionalmente, a sua
constituição está pautada no processo de reprodução do mesmo, pois a
força homogeneizadora que atua sobre a seleção reafirma as identidades e
afinidades e exclui, portanto, as diferenças, uma vez que essas são
incompatíveis com um todo que se quer uniforme e coerente em termos
de estéticos por excelência, argumento geralmente invocado na
ratificação do estatuto canônico de uma obra (Schmidt, 1996, p. 116).

Para os defensores do cânone, os princípios de seletividade "só são elitistas à medida que se fundem em critérios severamente artísticos” (Bloom, 1995, p. 30), sendo o estético incólume às relações de poder, que se detém ao mundo de lutas pelo acesso de todos às "altas literaturas", objetivo último do ensino de literatura (Perrone-Moisés, 1998). 
Outro fato é que mesmo entre os que desconfiam dos valores eleitos pelo cânone e acusam-nos de parcial vige, em alguma medida, essa concepção ${ }^{65}$. Flávio Kothe, um dos pesquisadores que questionam os valores do cânone, aceita a premissa de que é necessária a seleção na construção de uma historiografia literária, porque, para ele, “o pluriculturalismo pode até ser mais 'ético', mas não garante em si verdade nem arte" (Kothe, 1997, p. 26).

Conforme salientado por Schmidt, a formação de um cânone é resultado do estabelecimento de pressupostos e paradigmas de valorações dentro de um contexto em que muitos fatores entram em jogo, como, por exemplo, gênero literário e temáticas prestigiados, bem como estilo predominante em uma época. Os críticos literários dentro de seus gabinetes são um dos principais agentes nesse balaio de discursos que forma o que entendemos por literatura. $\mathrm{O}$ que compreendemos por literatura não apenas foi regido pelas normas, padrões e correntes estabelecidos por uma elite artística e intelectual, como também foi escrito, em sua grande maioria, por ela, que detém as regras do jogo do cânone.

Atualmente, como já salientado, passamos por um momento de questionamento da validade da noção de cânone ${ }^{66}$. A busca por determinação de valor, objetivo tido como intrínseco à crítica, é hoje colocado em questão como algo, no mínimo, relativo e passível de ponderação, principalmente pelos emergentes descentramentos epistemológicos motivados "pelos novos movimentos sociais: o feminismo, as lutas negras, os movimentos de libertação nacional, os movimentos antinucleares e ecológicos" (Hall, 2003, p. 21). A emergência de novos agentes no campo de produção da crítica contamina-a com outros objetivos, que não a construção de um cânone, de seus valores e de seus donos legítimos. Harold Bloom, como crítico defensor da noção de cânone, denomina a esses movimentos como "membros da Escola do Ressentimento" (Bloom, 1995, p. 28), em posicionamento de deboche e ataque aos novos grupos que questionam o discurso canônico.

Parecendo ser descendente direta do estudioso estadunidense Harold Bloom, a crítica literária Leyla Perrone-Moisés afirma: "A literatura, como disciplina escolar e universitária, parece ameaçada a desaparecer" (Perrone-Moisés, 2006, p. 17), diz

\footnotetext{
65 Ressalte-se, nesse âmbito, a crítica literária feminista, que, em sua maioria, não compartilha o objetivo da crítica hegemônica, mas questiona seus pressupostos.

${ }^{66}$ Há grande tradição de estudos contra-canônicos no âmbito dos estudos feministas e afro-brasileiros, bem como no contexto mais amplo de literatura latino-americana e hispânica.
} 
isso logo ao iniciar seu artigo "Literatura para todos", em que acusa os cursos básico e secundário como a raiz do problema e os cursos de graduação como prolongamento desses, inclusive nas defasagens dos discentes, que não são, segundo a autora, preparados "a adquirir maiores conhecimentos e competências" (Perrone-Moisés, 2006, p. 23).

Isso ocorre, de acordo com a autora, porque vivemos "o desprestígio progressivo do ensino da 'alta literatura' ou 'literatura difícil'”' (Perrone-Moisés, 2006, p. 27), desencadeado pela "excessiva preocupação com o 'contexto social' e a 'identidade', que aparece em todos os documentos do MEC, assim como o temor de um 'elitismo' que caracterizaria o ensino dos textos canônicos” (Perrone-Moisés, 2006, p. 28). A estudiosa conclui seu artigo defendendo ser o ensino das "altas literaturas" democratizador e subversivo, na medida em que está disponível a todos os alfabetizados.

O posicionamento de Leyla Perrone-Moisés desconsidera completamente outras tradições culturais, artísticas, literárias como dignas de serem integradas ao estudo de literatura, e mesmo relaciona a inserção dessas tradições no currículo com o precário nível de conhecimento dos alunos que chegam às universidades. A ojeriza aos estudos culturais fundamenta essas colocações, que reiteram a ideia de valores estáticos e canônicos.

Os produtores lidam com uma tradição, seja ela crítica ou literária, e com as demandas de inovação, que podem ser da própria tradição ou dos produtores, que trazem sua posicionalidade e formas de pertencimento no mundo - classe, raça, gênero, orientação sexual, nível de instrução formal, cultura familiar e social, entre outros elementos. Esse contexto gerado por novas demandas, empoderamento e militância de outros agentes do discurso impulsiona uma renovação da produção e da crítica, que se fazem com outros objetivos.

A visibilidade e a legitimidade de diversos produtores de cultura, arte e literatura talvez sejam as principais diretrizes desse novo momento epistemológico, até mesmo porque dessa forma muitos produtores de discursos críticos dão a ver o seu próprio local de enunciação, muitas vezes também marcado pelo signo das diferenças de classe, gênero, raça etc. Talvez essa seja a consequência primeira da redemocratização dos espaços de fala. A suposta intransponibilidade, fixidez e inquestionabilidade da ideia de cânone vem sendo paulatinamente substituída por valores de democratização, diversidade e heterogeneidade do campo social, tão 
combatidos por críticos defensores do cânone que vêem as produções artísticas em separado do mundo social.

A própria noção de tradição passa por um processo de subversão, ao entrarem em cena outras e diferentes tradições. Nada seria alterado se nos campos da literatura e do cordel novas tradições culturais e literárias não questionassem as que as antecederam, ultrapassando a barreira da reavaliação.

Se hoje é raridade encontrarmos publicações que busquem construir uma história da literatura ou uma historiografia literária e se a história da literatura vem sendo construída mediante ensaios e artigos publicados em livros esparsos, talvez seja porque estejamos vivendo um momento de reformulação, ou ao menos de revisão, de nosso modo de conceber a literatura, seus paradigmas e pressupostos teóricos e metodológicos.

Altera-se paulatinamente a posicionalidade de uma crítica, que substitui a ação de canonizar pela ação de questionar o canonizado e, posteriormente, acessar outros valores de tradição, de leitura, de recepção, de julgamento, permitindo-se, ao menos, a coexistência legítima, e sem hierarquias, de diferentes tradições culturais, artísticas, literárias.

É importante salientar que não foi objetivo desta tese subestimar e deslegitimar as contribuições dos críticos literários (Sílvio Romero, José Veríssimo, Afrânio Coutinho e Antonio Candido) ou dos críticos do cordel que serviram de interlocutores (pesquisadores da FCRB, Átila Almeida, José Alves Sobrinho, Raymond Cantel e prefaciadores da Coleção Biblioteca de Cordel), mas os limites de sua aplicação, que foram evidenciados pela existência de outras tradições culturais e literárias. Tomar essa tradição crítica de modo hegemônico reproduziria um esquema de subordinação, colonização a uma epistemologia que a colonialidade do poder instaurou.

Ao me decidir não trilhar um caminho já estabelecido e legitimado de análise crítica, sei que incorro, no mínimo, em um grande problema: minhas palavras articulam tão somente uma entrevoz, conforme conceitua a estudiosa feminista Andrea Nye (1995), e um balbucio, nos termos de Hugo Achugar (2006), sendo incapaz de formular uma epistemologia pronta e fechada para o estudo de todos os textos literários ou de todos os cordéis.

O que me conforta é saber que o mero início da movência dos discursos em direção à articulação de uma voz consiste em uma forma de abalar, mesmo que 
diminutamente, as estruturas vigentes, de modo que a articulação de um discurso já é capaz de interferir no discurso hegemônico. Esse ínfimo movimento epistemológico é o objetivo desta empreitada, que se propõe fragmentária, localizada e marginal, já que do contrário se faria excludente, como os discursos que questiona.

Quando se fala de uma poética em formação, que se propõe entre diferentes tradições e se diferencia de cada uma delas, como são as obras de Bastinha e Salete Maria da Silva, é impossível não se encharcar de impasses e não se localizar em um beco sem saída. Como trazer ao espaço da crítica literária e do cordel uma poética que é devota de uma tradição da oralidade e devota de uma agenda militante marxista e feminista?

Buscarei responder a essa indagação com base em um dos cordéis de Salete Maria, denominado Porque não sou obrigada, sendo esse justamente o primeiro argumento que trago como resposta: Porque não sou obrigada a seguir um traçado para o estudo de qualquer produção artística, e porque não sou obrigada a estudar o que alguém a priori chancelou como literatura para fazer crítica literária, até mesmo porque a grande maioria da história, da teoria e da crítica, seja da literatura ou do cordel, reforçam, e não questionam ou desafiam, os pressupostos de dominação colonial e de poder, de um modo geral.

A rebeldia que fomenta essas respostas não é maior que o imperativo de submissão que fundamenta as teorias da literatura. De acordo com o crítico Antoine Compagnon, "a teoria da literatura, como toda epistemologia, é uma escola de relativismo, não de pluralismo, pois não é possível deixar de escolher" (Compagnon, 2003, p. 262), contudo, como já mencionado, esse pressuposto pode ser questionado e mesmo desafiado por um fazer crítico que ignora a supremacia do cânone e de a seleção ser o único caminho a quem se atreve a falar de literatura. Nesse sentido, é importante considerar as ideias de Terry Eagleton.

\footnotetext{
Ocorre simplesmente que a teoria literária não é considerada relevante para tais questões [sociais]. Minha opinião, como já disse, é de que a teoria literária tem uma relevância muito particular para este sistema político: ela contribui, conscientemente ou não, para manter e reforçar seus pressupostos (Eagleton, 2006, p. 296).
}

Por isso, é tão importante pensar o local e os valores da história, crítica e teoria literárias e do cordel e enfrentar os interesses de hegemonia. A posição canônica, de uma crítica que prescinde de pensar-se em um sistema de poder, é alheia a ideais de democratização, diversidade e heterogeneidade. 
Assim, da mesma forma que a literatura e o cordel se transformam e ressignificam para permanecer vivos, a crítica terá de se ressignificar para permanecer viva. A meu ver é necessário reformular as categorias de análise e os pressupostos críticos, teóricos e metodológicos desenvolvidos para o estudo do cordel e da literatura de ontem no estudo do que é produzido hoje, até mesmo porque nós, críticos e críticas de hoje já somos outros, muitos outros. Caso contrário, ignoraremos que somos vidas afeitas à luta e que não somos obrigados a nada. 


\section{REFERÊNCIAS BIBLIOGRÁFICAS}

ABREU, Márcia (1999). Histórias de cordéis e folhetos. Campinas: Mercado de Letras: ALB.

ACHUGAR, Hugo (2006). Planetas sem boca: escritos efêmeros sobre arte, cultura e literatura. Tradução de Lyslei Nascimento. Belo Horizonte: Editora UFMG.

ADICHIE, Chimamanda (2009). Vídeo "Chimamanda Adichie: O perigo da história única".

ADORNO, Theodor; HORKHEIMER, Max (1985). A indústria cultural: o Iluminismo como mistificação das massas. Dialética do esclarecimento: fragmentos filosóficos. Tradução de Guido Antonio de Almeida. Rio de Janeiro: Jorge Zahar.

ALCOFORADO, Doralice F. Xavier (2007). Oralidade e literatura. In: LEITE, Eudes Fernando e FERNANDES, Frederico (orgs.). Oralidade e literatura 3: outras veredas da voz. Londrina-PR: EDUEL, v. 3.

ALMEIDA, Átila Augusto F. de e SOBRINHO, José Alves (1978). Dicionário biobibliográfico de repentistas e poetas de bancada. Tomo I e II. Campina Grande: Universitária; João Pessoa: Centro de Ciências e Tecnologia. (1981). Romanceiro popular nordestino: marcos e vantagens. Paraíba: UFPB.

ALVES FILHO, Ivan (1999). 500 anos em documentos. Rio de Janeiro: Mauad.

ALVES, Luis Alberto (2013). A dimensão política da obra de Afrânio Coutinho. A crítica literária brasileira em perspectiva. Cotia, São Paulo: Ateliê Editorial.

AMARO, Cuíca do Santo [José Gomes] (2000). Cuíca do Santo Amaro: controvérsia no cordel. Mark J. Curran (Introdução e Seleção). São Paulo: Hedra. (Coleção Biblioteca de Cordel).

AMORA, Antônio Soares (1986). A literatura do setecentos. In: COUTINHO, Afrânio; COUTINHO, Eduardo de Faria. $3^{\text {a }}$. ed. A literatura no Brasil. Rio de Janeiro: José Olympio; Niterói: UFF - Universidade Federal Fluminense (v. 2).

AMORA, Antônio Soares (1994). Fidelino Figueiredo na origem dos estudos de Literatura Portuguesa no Brasil. Estudos Avançados. São Paulo, v. 8, n. 22, p. 423-426.

AMORIM, Maria Alice (2007). No visgo do improviso ou a peleja virtual entre cibercultura e tradição. 118 f. Dissertação (Mestrado em Comunicação e Semiótica) - Programa de Estudos Pós-graduados em Comunicação e Semiótica, Pontíficia Universidade Católica de São Paulo.

ASSARÉ, Patativa [Antônio Gonçalves da Silva] (1956). Inspiração nordestina. Rio de Janeiro: Borsoi.

(2002 [1978]). Cante lá que eu canto cá. 13ª . ed. Petropolis: Vozes.

(2005). Patativa do Assaré uma voz do nordeste. $2^{\mathrm{a}}$. ed. Sylvie Debs (Introdução e Seleção). São Paulo: Hedra. (Coleção Biblioteca de Cordel). 
ATHAYDE, João Martins de (2005). João Martins de Athayde. Mário Souto Maior (Introdução e Seleção). São Paulo: Hedra (Coleção Biblioteca de Cordel).

AZEVEDO, Fernando de (1986). A escola e a literatura. In: COUTINHO, Afrânio; COUTINHO, Eduardo de Faria. $3^{\text {a }}$. ed. A literatura no Brasil. Rio de Janeiro: José Olympio; Niterói: UFF - Universidade Federal Fluminense. (v. 1).

AZEVEDO, Téo. Téo Azevedo (2003). Sebastião Geraldo Breguez (Introdução e Seleção). São Paulo: Hedra (Coleção Biblioteca de Cordel).

BAKHTIN, Mikail (1996 [1965]). A Cultura popular na Idade Média e no Renascimento: o contexto de François Rabelais. São Paulo: Hucitec/ UnB.

BAPTISTA, Abel Barros (2005). O cânone como formação: a teoria da literatura brasileira de Antonio Candido. In: O livro agreste. Campinas: Editora Unicamp.

BASSANEZI,C. Mulheres dos Anos Dourados (2004). In: DEL PRIORE, Mary(org.), História das mulheres no Brasil. São Paulo: Editora UNESP.

BASTOS, Elide Rugai; REGO, Walquiria D. Leão (1999). "Moralidade do compromisso". In: BASTOS, Elide Rugai; REGO, Walquiria D. Leão (org). Intelectuais e políticas: a moralidade do compromisso. São Paulo: Olhos d'água.

BATISTA, Francisco das Chagas (1997). Cantadores e poetas populares. 2a . ed. João Pessoa: UFPB - Editora Universitária.

(2007). Francisco das Chagas Batista. Altimar de Alencar Pimentel (Introdução e Seleção). São Paulo: Hedra (Coleção Biblioteca de Cordel).

BATISTA, Sebastião Nunes (1973). Restituição da autoria de folhetos. Catálogo, tomo I. (Literatura popular em verso). Estudos. Rio de Janeiro: MEC/Fundação Casa de Rui Barbosa.

(1982). Poética popular do Nordeste. (Literatura popular em verso). Estudos. Nova Série. Rio de Janeiro: MEC/Fundação Casa de Rui Barbosa.

BATISTA. Paulo Nunes (2005). Paulo Nunes Batista. Maria do Socorro Gomes Barbosa (Introdução e Seleção). São Paulo: Hedra (Coleção Biblioteca de Cordel).

BENSUSAN, Hilan (2008). Excessos e exceções: por uma ontologia sem cabimento. São Paulo: Ideias e Letras.

BHABHA, Homi (2012). O local da cultura. Tradução de Eliana Lourenço de Lima Reis. Minas Gerais: Editora UFMG.

BLOOM, Harold (1995). Uma elegia para o cânone. In: O cânone ocidental. São Paulo: Objetiva.

BOSI, Alfredo (2008). Dialética da colonização. 4ª ed. São Paulo: Companhia das Letras.

BOURDIEU, Pierre (1996). As regras da arte: gênese e estrutura do campo literário. Tradução de Maria Lúcia Machado. 2a . ed. São Paulo: Companhia das Letras. 
(2006). O poder simbólico. Tradução de Fernando Tomaz. 9a. ed. Rio de Janeiro:

Bertrand Brasil.

(2007). A distinção: crítica social do julgamento. Tradução de Daneila Kern e

Guilherme J. F. Teixeira. São Paulo: Edusp; Porto Alegre: Zouk.

BURKE, Peter (1989). Cultura popular na idade moderna. Tradução de Denise Bottmann. $2^{\text {a }}$. ed. São Paulo: Companhia das Letras.

BUTLER, Judith (1993). Bodies that matters: on the discursive limits of sex. New York: Routledge.

(1998). Fundamentos contingentes: o feminismo e a questão do pós-modernismo.

Cadernos Pagu, n. 11, 1998, p. 11-42. Tradução de Pedro Maia Soares para versão do artigo "Contingent Foundations: Feminism and the Question of Postmodernism", no Greater Philadelphia Philosophy Consortium, em setembro de 1990.

CAIRO, Luiz Roberto (1996). O salto por cima da própria sombra: o discurso crítico de Araripe Júnior: uma leitura. São Paulo: Annablume.

CAMPOS, Haroldo (1989). O sequestro do barroco na formação da literatura brasileira: o caso Gregório de Matos. Salvador: Fundação Casa de Jorge Amado.

CANCLINI, Nestor Garcia (1998). Cultura hibrida: estratégias para entrar e sair da modernidade. São Paulo: EDUSP.

CANDIDO, Antonio ([1984] 2004). Uma palavra instável. In: Vários escritos. $4^{\mathrm{a}}$. ed. Rio de Janeiro: Ouro Sobre Azul; São Paulo: Duas Cidades.

([1988] 2004). O direito à literatura. In: Vários escritos. $4^{\mathrm{a}}$. ed. Rio de Janeiro: Ouro Sobre Azul; São Paulo: Duas Cidades.

(1980). Clima. In: Teresina etc. Rio de Janeiro: Paz e Terra.

(1981). Exposición de Antonio Candido. In: PIZZARRO, Ana (coord.). La literatura letionamericana como processo. Buenos Aires: Association pour l'etude sócioculturelle des Arts, des litteratures de l'Amerique Latina.

(1986). O escritor e o público. In: COUTINHO, Afrânio; COUTINHO, Eduardo de Faria. $3^{a}$. ed. A literatura no Brasil (v. 1). Rio de Janeiro: José Olympio; Niterói: UFF Universidade Federal Fluminense.

São Paulo.

(1988). O método crítico de Sílvio Romero. São Paulo: Editora da Universidade de

(1997). Iniciação à literatura brasileira (resumo para principiantes). São Paulo: Editora Humanitas.

(2000). Formação da literatura brasileira: momentos decisivos (v. 1 e 2). $6^{\text {a }}$. ed. Belo Horizonte: Itatiaia.

(2004). O discurso e a cidade. $3^{\text {a }}$. ed. Rio de Janeiro: Ouro sobre Azul. 
(2006) Literatura e subdesenvolvimento. In: . A educação pela noite. $5^{\mathrm{a}}$. ed. Rio de Janeiro: Ouro sobre Azul.

CARDOSO, Wilton (1986). A língua literária. In: COUTINHO, Afrânio; COUTINHO, Eduardo de Faria. $3^{\mathrm{a}}$. ed. A literatura no Brasil (volume 1). Rio de Janeiro: José Olympio; Niterói: UFF - Universidade Federal Fluminense.

CARVALHO, Gilmar de (2002a), Patativa poeta pássaro do Assaré. 2ª ed. Fortaleza: Omni Editora Associados.

(2002b). Vozes e letras do cordel. CULT: Revista Brasileira de Literatura, ano 5, n. 54, p. 43-49, jan.

CARVALHO, José de Rodrigues (1967). Cancioneiro do Norte. $3^{\text {a }}$. ed. Rio de Janeiro: Instituto Nacional do Livro.

CASANOVA, Pascale (2002). As pequenas literaturas. In: A República Mundial das Letras. São Paulo: Estação Liberdade.

CASCUDO, Luís da Câmara (1986). O folclore: literatura oral e literatura popular. In: COUTINHO, Afrânio; COUTINHO, Eduardo de Faria. 3. ${ }^{a}$ ed. A literatura no Brasil (volume 1). Rio de Janeiro: José Olympio; Niterói: UFF - Universidade Federal Fluminense, p. 183-192.

CASTRO, José Ariel (1986). Formação e desenvolvimento da língua nacional brasileira. In: COUTINHO, Afrânio; COUTINHO, Eduardo de Faria. 3. ${ }^{a}$ ed. A literatura no Brasil (volume 1). Rio de Janeiro: José Olympio; Niterói: UFF - Universidade Federal Fluminense.

CAVALCANTE, Rodolfo Coelho (2003). Rodolfo Coelho Cavalcanti. Eno Theodoro Wanke (Introdução). São Paulo: Hedra (Coleção Biblioteca de Cordel).

CHARTIER, Roger (1999). A aventura do livro: do leitor ao navegador; conversações com Jean Lehum. São Paulo: UNESPE/IMESP. Editora UNESP. (2002). Os desafios da escrita. Tradução de Fúlvia M. L. Moretto. São Paulo:

CHAUÍ, Marilena (2006). Intelectual engajado: uma figura em extinção?. In: NOVAES, Adauto (org.). O silêncio dos intelectuais. São Paulo: Companhia das Letras.

CIRESE, A. M. (1980). Ensayos sobre las culturas subalterna. Cuadernos de la casa Chata. Cidade do México.

CLÉMENT, Jean-Pierre; LEMAIRE, Ria (2005). Raymond Cantel: La littérature populaire brésilienne. Poitiers: Centre de Recherches Latino-Américaines.

COLASANTI, Marina (1997). Por que nos perguntam se existimos. In: SHARPE, Peggy (org.). Entre resistir e identificar-se: para uma teoria da prática da narrativa brasileira de autoria feminina. Florianopolis: Mulheres; Goiania: EdUFG.

COMPAGNON, Antoine (2003). O demônio da teoria: literatura e sendo comum. Tradução de Cleonice Paes Barreto Mourão e Consuelo Fortes Santiago. Belo Horizonte: Editora UFMG. 
COUTINHO FILHO, Francisco (1972). Violas e repentes. Rio de Janeiro: Leitura.

COUTINHO, Afrânio (1953). Correntes cruzadas. Rio de Janeiro: A Noite.

(1980). Introdução à literatura no Brasil. Rio de Janeiro: Civilização Brasileira.

(1986). Preliminares. COUTINHO, Afrânio; COUTINHO, Eduardo de Faria. $3^{\text {a }}$. ed. A literatura no Brasil (volume 1). Rio de Janeiro: José Olympio; Niterói: UFF Universidade Federal Fluminense.

COUTINHO, Eduardo de Faria (1996). Literatura comparada, literaturas nacionais e o questionamento do cânone. Revista brasileira de literatura comparada. $\mathrm{n}^{\circ} 3$. Rio de Janeiro: Abralic, p. 67-73.

CURRAN, Marck J. (1973). A sátira e a crítica social na literatura de cordel. Literatura popular em versos. Estudos. Tomo I. Rio de Janeiro: MEC- Fundação Casa de Rui Barbosa.

(1987). A presença de Rodolfo Coelho Cavalcanti na moderna literatura de cordel. Rio de Janeiro: Nova Fronteira.

DALCASTAGNÈ, Regina (2012). Literatura brasileira contemporânea: um território contestado. Rio de Janeiro;Vinhedo: Editora da UERJ;Horizonte.

DAUPHIN. C (1992). Mulheres sós. In: DUBY, G.; PERROT, M. (orgs.). História das mulheres no Ocidente no Século XIX. Porto, Portugal: Afrontamento.

DAUS, Ronald (1982). O ciclo dos cangaceiros na poesia popular do Nordeste. Literatura popular em versos. Estudos. Tomo I. Rio de Janeiro: MEC - Fundação Casa de Rui Barbosa.

DERRIDA, Jacques (1995). A escritura e a diferença. Tradução de Narua Beatriz Marques Nizza da Silva. 2a . ed. São Paulo: Perspectiva (Debates, 49).

(1999). Gramatologia. Tradução de Miriam Schnaiderman e Renato Janini Ribeiro. São Paulo: Perspectiva.

DIÉGUES JÚNIOR, Manuel (1973). Ciclos temáticos na literatura de cordel. Literatura popular em versos. Estudos. Tomo I. Rio de Janeiro: MEC - Fundação Casa de Rui Barbosa. folclore, 2 ).

(1975). Literatura de cordel. Rio de Janeiro: Olímpica Editora, 1975 (Cadernos de

DUARTE, Eduardo de Assis (2014). Literatura afro-brasileira: abordagens na sala de aula. Rio de Janeiro: Pallas.

DUTRA, Waltensir (1986). O arcadismo na poesia lírica, épica e satírica. In: COUTINHO, Afrânio; COUTINHO, Eduardo de Faria. $3^{\mathrm{a}}$. ed. A literatura no Brasil (v. 2). Rio de Janeiro: José Olympio; Niterói: UFF - Universidade Federal Fluminense.

EAGLETON, Terry (2005) Depois da teoria: um olhar sobre os Estudos Culturais e o pósmodernismo. Tradução de Maria Lucia Oliveira. Rio de Janeiro: Civilização Brasileira.

(2006). Teoria da literatura: uma introdução. $6^{a}$ ed. Tradução de Waltensir Dutra. São Paulo: Martins Fontes. 
FAORO, Raymundo (2012 [1958]). Os donos do poder: formação do patronato político brasileiro. São Paulo: Biblioteca Azul.

FEITOSA, Luiz Tadeu (2003). Patativa do Assaré: a trajetória de um canto. São Paulo: Escrituras.

FERREIRA, Jerusa Pires (1997). Livros e editoras populares. In: FERREIRA, Jerusa Pires et al. (Org.). Livros, editoras e projetos. São Paulo: Ateliê Editorial Com - Arte. São Bernardo do Campo, SP: Bartira.

FERRÉZ (2006). O pão e a revolução. Ninguém é inocente em São Paulo. Rio de Janeiro: Objetiva.

FISCHER, Luís Augusto (2013). Formação, hoje: uma hipótese analítica, alguns pontos cegos e seu vigor. In: CORDEIRO, Rogério. A crítica literária brasileira em perspectiva. Cotia, São Paulo: Ateliê Editorial.

FOUCAULT, Michel (1990). História da Sexualidade 2. Rio de Janeiro: Graal.

Graal. (1993). História da Sexualidade 1: a vontade de saber. 11ª ed. Rio de Janeiro:

(2005). Ordem do discurso. $16^{a}$. ed. Tradução de Aura Fraga de Almeida Sampaio. São Paulo: Loyola.

(2007). Os intelectuais e o poder: conversa entre Michel Foucault e Guilles Deleuze. Microfísica do poder. $25^{\text {a }}$. ed. Organização e tradução de Roberto Machado. Rio de Janeiro: Edições Graal, p. 69-78.

FREIRE, José da Rocha [Zé Melancia] (2005). Zé Melancia. Martine Kunz (Introdução e Seleção). São Paulo: Hedra (Coleção Biblioteca de Cordel).

FREYRE, Gilberto (2006 [1933]). Casa grande \& senzala. São Paulo: Global.

FUNDAÇÃO CASA DE RUI BARBOSA (1962). Literatura popular em verso. Rio de Janeiro: MEC/FCRB. Catálogo.

Antologia.

(1964). Literatura popular em verso. Tomo I. Rio de Janeiro: MEC/FCRB/UFPB.

(1976). Literatura popular em verso. Tomo II. Leandro Gomes de Barros 1. Rio de Janeiro: MEC/FCRB/FURN. Antologia.

(1977). Literatura popular em verso. Tomo IV. Francisco das Chagas Batista. Rio de Janeiro: MEC/FCRB. Antologia.

(1983). O cordel e os desmantelos do mundo. In: LESSA, Orígenes; LUNA, Vera Lúcia de e Silva. Rio de Janeiro: FCRB. (Literatura popular em verso). Antologia. Nova Série1.

Nova série.

(1987). O cordel testemunha da história do Brasil. Rio Janeiro: FCRB. Antologia. 
(1989). O negro na Literatura de Cordel. Rio de Janeiro: FCRB. Estudos, n. 7. Disponível em: www.casaruibarbosa.gov.br/template_01/default.asp?VID_Secao=10. Acesso em: 10 abr. 2010.

FURTADO, Celso (2007 [1959]). Formação econômica do Brasil. São Paulo: Companhia das Letras.

GADZEKPO, John Rex Amuzu (2004). Do folheto à tela cibernética: histórico, cotidiano e sobrevivência do cordel. In: MARTINS, Clerton (Org.). Antropologia das coisas do povo. São Paulo: Roca.

GALVÃO, Ana Maria de Oliveira (2001). Cordel: leitores e ouvintes. Belo Horizonte: Autêntica.

GAMA, Luiz ([1860?] 2000). Prótase. Primeiras Trovas Burlescas e outros poemas. Organização, introdução e notas de Ligia Fonseca Ferreira. São Paulo: Martins Fontes.

GAUDENCIO, Sale Mário (2014). Representação da informação de cibercordéis em blogs: uma análise sob a luz da semântica discursiva. 2014. 232 f. Dissertação (Mestrado em Informação, conhecimento e sociedade) - Universidade Federal da Paraíba, João Pessoa.

GELB, Ignace J (1952). A Study of Writing: the foundations of grammatology. London: Routledge and Kegan Paul.

GILBERT, Sandra M.; GUBAR, Susan (1979). Infection in the Sentence: The Woman Writer and the Anxiety of Authorship. In: The Madwoman in the Attic: The Woman Writer and the Nineteenth-Century Literary Imagination.

GINZBURG, Carlo (1987). O queijo e os vermes: o cotidiano e as ideias de um moleiro perseguido pela inquisição. Tradução de Maria Betânia Amoroso e José Paulo Paes. São Paulo: Companhia das Letras.

GINZBURG, Jaime (2002). Idealismo e consciência política em teoria da literatura. Revista da ANPOLL, v. 1, n. 13, jul./dez. p. 51-71.

1, p. 98-107.

(2008). O valor estético: entre universalidade e exclusão. ALEA (online), v. 10, n.

GOODY, Jack; WATT, Ian (1996). Cultura escrita en sociedades tradicionales. Barcelona, España: Gedisa.

GRAMSCI, Antonio (1968). Os intelectuais e a organização da cultura. Tradução de Carlos Nelson Coutinho. Rio de Janeiro: Civilização Brasileira.

HALL, Stuart (2003). A identidade cultural na pós-modernidade. Tradução de Tomaz Tadeu da Silva e Guacira Lopes Louro. Rio de Janeiro: DP\&A.

HARDT, Michael; NEGRI, Antonio (2001). Império. Tradução de Berilo Vargas. 2a . ed. Rio de Janeiro: Record.

HAVELOCK, Eric A. (1996). A musa aprende a escrever: reflexões sobre a oralidade e a literacia da antiguidade ao presente. Tradução de Maria Leonor Santa Bárbara. Lisboa: Gradiva. 
(1997). Prefácio a Platão. Tradução de E. A Dobránzsky. Campinas: Papirus.

HELENA, Raimundo Santa [Raimundo Luiz do Nascimento] (2003). Raimundo Santa

Helena. Bráulio Tavares (Introdução e Seleção). São Paulo: Hedra (Coleção Biblioteca de Cordel).

HOLANDA, Sérgio Buarque de (1953). Antologia dos poetas brasileiros fase colonial. v. 1. Editora MEC.

(1997 [1936]), Raízes do Brasil. 3ª ed. São Paulo: Companhia das Letras.

HOLLANDA, Heloísa Buarque de (1993). O que querem os dicionários?. In: ARAÚJO, Lúcia Nascimento. Ensaístas brasileiras. Rio de Janeiro: Rocco.

INNIS, Harold Adams (1964 [1951]). The Bias of Communication. Intro. Marshall McLuhan. Toronto: Univerity of Toronto Press.

JOB, Sebastiana Gomes de Almeida (1991). Prece de uma solteirona.

(1998). Dona Flor e seus namorados.

JOSÉ, Severino [Zacarias José dos Santos] (2001). Severino José. Luiz de Assis Monteiro (Introdução e Seleção). São Paulo: Hedra (Coleção Biblioteca de Cordel).

KOLODNY, Annete ([1976] 1980). Dancing Through the Minefield: Some Observations on the Theory, Practice and Politics of a Feminist Literary Criticism. Feminist Studies 6 (1980): $1-25$.

KOTHE, Flávio R (1997). Cânone colonial: ensaio. Brasília: Editora Universidade de Brasília.

LAURETIS, Teresa (1990). Eccentric subject: feminist theory and historical consciousness. Revista Feminist Studies, v. 16, n. 1.

(1994). A tecnologia do gênero. Tradução de Susana Borneo Funck. In:

HOLLANDA, Heloísa Buarque de (org.). Tendências e impasses: o feminismo como crítica da cultura. Rio de Janeiro: Rocco.

LE GOFF, Jacques (1990). História e memória. Tradução de Bernardo Leitão. Campinas, SP: Editora da UNICAMP.

LEAL, Virgínia Maria Vasconcelos (2008). As escritoras contemporâneas e o campo literário brasileiro: uma reflexão de gênero. Tese de doutorado. Brasília: Programa de PósGraduação em Literatura, Universidade de Brasília.

LEMAIRE, Ria (1988). Passions et positions: contribution pour une sémiotique du sujet dans la poésie lyrique en langues romanes. Amsterdam: Rodopi.

(1994). Repensando a história literária. In: HOLLANDA, Heloísa Buarque de. (org.). Tendências e impasses: o feminismo como crítica da cultura. Rio de Janeiro: Rocco. 
(2002). Herói literário e historiador: caminhos cruzados nos prefácios de Casagrande \& senzala. In: GIUCCI, Guillermo et al. (orgs.). Casa grande e senzala. Edição crítica. Coleção Archivos, n. 55. Paris: Edições Unesco.

(2007). Folheto ou literatura de cordel: uma questão de vida ou morte. In: Anais do XII Congresso de Folclore. Natal, Comissão Nacional de Folclore.

(2007). Reler os textos - resgatar as vozes?. Tradições populares açorianas. Ponta Delgada-Açores: Ed. da Universidade.

(2011). As verdades da verdade: o folheto entre oralidade e escrita. Literatura culta e popular em Portugal e no Brasil: homenagem a Arnaldo Saraiva. Porto: CITCEM Edições Afrontamento.

LESSA, Orígenes (1984). A voz dos poetas. Rio de Janeiro: FCRB (Literatura popular em verso).

LEVI-STRAUSS, Claude (1962). La pensée sauvage. Paris: Librairie Plon.

LÉVY, Pierre (1999). Cibercultura. São Paulo: Editora 34.

Loyola. (2007). Inteligência coletiva: para uma antropologia do ciberespaço. São Paulo:

LORD, Albert B (1960). The singer of tales. Cambridge, MA: Harvard University Press.

LUCENA, Bruna Paiva de (2009). Novas dicções no campo literário brasileiro: Patativa do Assaré e Carolina Maria de Jesus. Estudos de literatura brasileira contemporânea. Brasília, n. 34, jul./dez. p. 73-93.

(2010). Cante lá que eu canto cá: poéticas populares dentro e fora da moldura. Estudos de literatura brasileira contemporânea. Brasília, n. 35, jan./jun.

(2010). Espaços em disputa: o cordel e o campo literário brasileiro. Dissertação (Mestrado em Literatura) - Universidade de Brasília.

(2010). Nas brenhas da tradição: a cordelista maudita Salete Maria. In:

DALCASTAGNÈ, Regina; LEAL, Virgínia Maria Vasconcelos (orgs.). Deslocamentos de gênero na narrativa brasileira contemporânea. São Paulo: Horizonte.

MACHADO DE ASSIS, Joaquim Maria (1959 [1873]). Notícias da atual literatura brasileira: instinto de nacionalidade. In: . Machado de Assis: crítica, notícia da atual literatura brasileira. São Paulo: Agir.

MALARD, Letícia (2013). José Veríssimo: crítico literário. In: CORDEIRO, Rogério. A crítica literária brasileira em perspectiva. Cotia, São Paulo: Ateliê Editorial.

MANNHEIM, Karl (1956). O problema do intelectual. Tradução de Sylvio Uliana. In: . Essays on the sociology of culture London: Routledge and Kegan Paul.

Perspectiva. (1974). Sociologia da cultura. Tradução de Roberto Gambini. São Paulo: 
MARQUES, Reinaldo Martiniano (2011). Domingos Caldas Barbosa. In: DUARTE, Eduardo de Assis. Literatura e afrodescendância no Brasil: antologia crítica. Belo Horizonte: Editora UFMG.

MARTÍN-BARBERO, Jesús (2003). Dos meios às mediações: comunicação, cultura e hegemonia. Rio de Janeiro: Ed. UFRJ.

MARTINS, Neco [Manoel Martins de Oliveira] (2004). Neco Martins. Gilmar de Carvalho (Introdução e Seleção). São Paulo: Hedra (Coleção Biblioteca de Cordel).

MATA, Anderson Luís Nunes da (2010). As fraturas no projeto de uma literatura nacional: representação na narrativa brasileira contemporânea. 2010. 180 f. Tese (Doutorado em Literatura) - Universidade de Brasília, Brasília.

MAXADO, Franklin (2007). Franklin Maxado. Antônio Amaury Corrêa de Araújo (Introdução e Seleção). São Paulo: Hedra (Coleção Biblioteca de Cordel).

MAYR, Ernst (1963). Animal species and evolution. Cambridge, Mass: Belknap Press.

MCLUHAN, Marshall (1998 [1962]). The Gutenberg galaxy. Toronto: Toronto.

MELO, Rosilene Alves de (2003). Arcanos do verso: trajetórias da tipografia São Francisco em Juazeiro do Norte, 1926-1982. 2003. 221 f.. Dissertação (Mestrado em História) - Departamento de História, Universidade Federal do Ceará, Fortaleza.

MENDES, Simone de Paula dos Santos (2011). Um estudo da argumentação em cordéis midiatizados: da enunciação performática à construção discursiva da opinião. Tese (Doutorado em Linguística do Texto e do Discurso). Universidade Federal de Minas Gerais, Belo Horizonte.

MENDONÇA, Maristela Barbosa de (1993). Uma voz feminina no mundo do folheto. Brasília: Thesaurus.

MICELI, Sérgio (2011). Intelectuais à brasileira. São Paulo: Companhia das Letras.

MIGNOLO, Walter D. (2003). Histórias locais/ Projetos globais: colonialidade, saberes subalternos e pensamento liminar. Tradução de Solange Ribeiro de Oliveira. Belo Horizonte: Editora UFMG.

MOREIRA, Maria Eunice (2013). O Brasil em papel: ideias e propostas no pensamento crítico do romantismo. In: CORDEIRO, Rogério et al (org.). A crítica literária brasileira em perspectiva. Cotia, São Paulo: Ateliê Editorial.

MOTTA, Leda Tenório da (2002). Sobre a crítica literária brasileira no último século. Rio de Janeiro: Imago.

MOURALIS, Bernard (1982). As contraliteraturas. Coimbra: Almedina.

MUCHEMBLED, Robert (1991[1978]). Culture populaire et culture des élites dans la France moderne (XVe-XVIIIe siècle). Paris: Flammarion.

NAVARO-SWAIN, Tania (2006). Os limites discursivos da história: imposição de sentidos. Labrys: Revista de Estudos Feministas, n. 9. 
NYE, Andrea (1995). Teoria feminista e as filosofias do homem. Tradução de Nathanael C. Caixeiro. Rio de Janeiro: Rosa dos Tempos.

ONG, Walter J. (2004 [1958]). Ramus, method, and the decay of dialogue: from the art of discourse to the art of reason. Chicago: University of Chicago Press.

ORTIZ, Renato (1986). Cultura brasileira e identidade nacional. 2ª ed. São Paulo: Brasiliense.

PARRY, Milmam (1928). L'épithete traditionnelle dans Homere. Paris: Les Belles Lettres.

PEREIRA, Lúcia Miguel ([1950], 1988). História da literatura brasileira: prosa de ficção, de 1870 a 1920. Belo Horizonte/São Paulo: Itatiaia/Editora da Universidade de São Paulo.

PERRONE-MOISÉS, Leyla (1998). Altas literaturas: escolha e valor na obra crítica de escritores modernos. São Paulo: Companhia das Letras.

São Paulo.

(2006). Literatura para todos. Literatura e sociedade, n. 9, p. 16 -29, dez. 2006.

PRADO JÚNIOR, Caio (2011 [1942]). Formação do Brasil contemporâneo: colônia. São Paulo: Companhia das Letras.

(2012 [1933]). Evolução política do Brasil: e outros estudos. São Paulo:

Companhia das Letras.

PRADO, Paulo (2012 [1928]). Retrato do Brasil: ensaio sobre a tristeza brasileira. 10ª ed. São Paulo: Companhia das Letras.

QUIJANO, Anibal ([1971]2014). Dominación y cultura. Notas sobre el problema de la participación cultural. In: Cuestiones y horizontes : de la dependencia histórico-estructural a la colonialidad/descolonialidad del poder. Buenos Aires: CLACSO.

Lima.

(1992). Colonialidad y modernidad/racionalidad. Peru indígena, v.13, n. 29.

(2005). Colonialidade do poder, eurocentrismo e América Latina. In: LANDER, Edgardo (org). A colonialidade do saber: eurocentrismo e ciências sociais. Perspectivas latino-americanas. Colección Sur Sur, CLACSO, Ciudad Autónoma de Buenos Aires, Argentina, p. 227-278.

QUINTELA, Vilma Mota (2005). O cordel no fogo cruzado da cultura. 2005. 226 f.. Tese (Doutorado em Letras e Linguística). Instituto de Letras, Universidade Federal da Bahia, Salvador.

RAMA, Angel (1984). A cidade das Letras. Tradução de Emir Sade. São Paulo: Brasiliense.

RAZZINI, Márcia de Paula Gregório (2010). História da disciplina Português nas escolas secundárias brasileiras. Revista tempos e espaços em educação, v. 4. jan./jun. p. 43-58.

REDFIELD, Robert (1969). The social organization of tradition. In: Peasant society and culture: an anthropological approach to civilization. 
REIS, Maria Firmina dos (2004). Úrsula. 4ª . ed. Atualização do texto e posfácio de Eduardo de Assis Duarte. Florianópolis: Editora Mulheres; Belo Horizonte: PUC Minas.

REIS, Roberto (1992). Cânon. In: JOBIM, José Luis. Palavras da crítica: tendências e conceitos no estudo da literatura. Rio de Janeiro: Imago.

RENNÓ, Adriana Campos (1999). Violando as regras: uma (re)leitura de Domingos Caldas Barbosa. São Paulo: Arte \& Ciência.

(2005). Caldas Barbosa e o pecado das orelhas: a poesia árcade, a modinha e o lundu (textos recolhidos e antologia poética). São Paulo: Arte \& Ciência.

RICHARD, Nelly (2002). Intervenções críticas: arte, cultura, gênero e política. Tradução de Rômulo Monte Alto. Belo Horizonte: Editora UFMG.

RINARÉ, Rouxinol do [Antonio Carlos da Silva] (2007). Rouxinol do Rinaré. Ribamar Lopes (Introdução e Seleção). São Paulo: Hedra (Coleção Biblioteca de Cordel).

ROCHA, João Cezar de Castro (2011a). Crítica literária: em busca do tempo perdido? Chapecó: Argos.

(2011b). Sílvio Romero: a polêmica como sistema?. CORDEIRO, Rogério et al. (org.). A crítica literária brasileira em perspectiva. Cotia, São Paulo: Ateliê Editorial.

ROMERO, Sílvio (1888). História da literatura brasileira: fatores da literatura brasileira. Disponível em: <http://www.santoandre.sp.gov.br/pesquisa/ebooks/344495.pdf>. Acesso em: 15 mar. 2014.

(2001). História da literatura brasileira. Rio de Janeiro: Imago (edição comemorativa).

SAID, Edward (2007). Orientalismo: o Oriente como invenção do Ocidente. Tradução de Rosaura Eichenberg. São Paulo: Companhia das Letras.

SALDANHA, Zé (2001). Zé Saldanha. Gutenberg Costa (Introdução e Seleção). São Paulo: Hedra (Coleção Biblioteca de Cordel).

SALLES, Vicente (1971). Guajarina, folhetaria de Francisco Lopes. Revista Brasileira de Cultura. Conselho Federal de Cultura. Ministério da Educação. Rio de Janeiro, ano III, v. 9, p. 87-102. julho/setembro.

SANTANA, Sammyra (2014). Como surgiu o blog Cordelirando. Disponível em: <http://cordelirando.blogspot.com.br/2014/07/como-surgiu-o-blogcordelirando.html.>.Acesso em: 6 jul., 2014.

SANTOS, Boaventura de Souza (2003). Por uma concepção multicultural de direitos humanos In: SANTOS, Boaventura de Souza. Reconhecer para libertar: os caminhos do cosmopolitismo multicultural. Rio de Janeiro: Civilização Brasileira.

SANTOS, Francisca Pereira dos (2008). Romaria de versos: mulheres cearenses autoras de cordel. Cariri: SESC. 
(2009). Novas cartografias no cordel e na cantoria: desterritorialização de gênero nas poéticas das vozes. Tese (Doutorado em Literatura e Cultura). Universidade Federal da Paraíba, UFPB.

(2011). Aguá da mesma onda: a peleja poética epistolar entre a poetisa Bastinha e o poeta Patativa do Assaré. Fortaleza: Iris.

SANTOS, Francisca Pereira; SILVA, Salete Maria (2004). Dimas, o bom ladrão?. In: HOLANDA, Arlene (org.). Cor de cordel. Fortaleza: Premius.

SANTOS, Idelette Muzart Fonseca dos (1995). Escritura da voz e memória do texto: abordagens atuais da literatura popular brasileira. In: BERND, Zilá; MIGOZZI, Jacques (org.). Fronteiras do literário, Literatura oral e popular Brasil/França. Porto Alegre: Editora da UFRGS.

SANTOS, Maria Inês Detsi de Andrade (2004). Gênero e comunicação: o masculino e o feminino em programas populares de rádio. São Paulo: Annablume.

SANTOS, Olga de Jesus (1989). O negro na literatura de cordel. Rio de Janeiro: Fundação Casa de Rui Barbosa. (Literatura popular em verso). Estudos. Nova série.

SARAIVA, Antonio José; Lopes, Osório (1996). História da literatura portuguesa. 17ª . ed. Porto: Porto Editora.

SARAIVA, Arnaldo (1975). Literatura marginalizada. Porto: [s. n.].

SAWAYA, Luiza (2011). Domingos Caldas Barbosa: para além da Viola de Lereno. Dissertação (Mestrado em Estudos Românicos). Lisboa: FLUL.

SCHMIDT, Rita Teresinha (1994). Da ginolatria à genologia: sobre a função teórica e a prática feminista. In: FUNK, Susana Bornéo (org.). Trocando ideias sobre a mulher e a literatura. Florianópolis, SC: Universidade Federal de Santa Catarina, 1994.

(1995). Repensando a cultura, a literatura e o espaço da autoria feminina. In: NAVARRO, Márcia Hoppe (org.). Rompendo o silêncio. Porto Alegre: Editora da UFRGS, 1995.

(1996). Cânone e contra-cânone: nem aquele que é o mesmo nem este que é o outro. In: CARVALHAL, Tânia Franco (org.). O discurso crítico na América Latina. Porto Alegre: IEL - Editora da Unissinos, 1996.

(1997). O papel do profissional de Letras: compromisso com a realidade.

Cadernos do Instituto de Letras, Porto Alegre, UFRGS, n. 18, dez.

(1998). Em busca da história não contada ou: o que acontece quando o objeto começa a falar? Revista do mestrado em Letras da UFMS. jan./jul. p. 183-196.

(2002). A crítica feminista na mirada da crítica". Ilha do Desterro, n. 42.

Florianópolis: jan./jun., p. 103-125.

(2006). Refutações ao feminismo: (des)compassos da cultura letrada brasileira.

Estudos Feministas, Florianópolis, v. 14, n. 3, p. 765, jan. 
SCHOLES, Robert; KELLOG, Robert (1977). A natureza da narrativa. Recife: McGrawHill do Brasil.

SCHÜLER, Donaldo (2001). Na conquista do Brasil. São Paulo: Ateliê Editorial.

SCOTT, James C (2011). Exploração normal, resistência normal. Revista Brasileira de Ciência Política. Brasília, n. 5, p. 217-243, jul.

SHOHAT, Ella; STAM, Robert (2006). Crítica da imagem eurocêntrica: multiculturalismo e representação. Tradução de Marcos Soares. São Paulo: Cosac Naify.

SILVA, Alexandra Barbosa da (1997). Entre a feira e a academia: a questão da legitimidade entre cordelistas no Rio de Janeiro. 1997. Dissertação (Mestrado em Antropologia Social) Museu Nacional - UFRJ. Rio de Janeiro.

SILVA, Expedito Sebastião da (2001). Expedito Sebastião da Silva. Martine Kunz (Introdução e Seleção). São Paulo: Hedra (Coleção Biblioteca de Cordel).

SILVA, Franklin Leopoldo (2006). O imperativo ético de Sartre. In: NOVAES, Adauto (org). O silêncio dos intelectuais. São Paulo: Companhia das Letras.

SILVA, Manoel Caboclo (2000). Manoel Caboclo. Gilmar de Carvalho (Introdução e Seleção). São Paulo: Hedra (Coleção Biblioteca de Cordel).

SILVA, Minelvino Francisco (2005). Minelvino Francisco Silva. Introdução e Seleção de Edilene Matos. São Paulo: Hedra (Coleção Biblioteca de Cordel).

SILVA, Salete Maria da (2005). Mulher também faz cordel. (2008). Maria, Helena. (2010). O milagre travesthriller: a história da travesti que (com fé) engravidou. (2012a). A desforra de Bartira. (2012b). Manifesto pelas mães trabalhadoras. (2014). 20 anos de cordel: tô aqui pra celebrar.

SLATER, Candace (1984). A vida no barbante: a literatura de cordel no Brasil. Rio de Janeiro: Civilização Brasileira.

SOARES, José (2007). José Soares. Introdução e Seleção de Mark Dinneen.São Paulo: Hedra (Coleção Biblioteca de Cordel).

SOBRINHO, José Alves (1975). Sabedoria de caboco. Campina Grande: Gráfica Baiana. (1982) Glossário da poesia popular. Campina Grande: Editel. (1994). Matulão de um andarilho. Campina Grande: Gráfica União. (2003). Cantadores, repentistas e poetas populares. Campina Grande: Bagagem. 
SODRÉ, Nelson Werneck (1944). Formação da sociedade brasileira. Rio de Janeiro: José Olympio.

Mauad.

(1998). Vamos deter a traição. In: . Tudo é Política. Rio de Janeiro:

(2001). História da Imprensa no Brasil. São Paulo: Martins Fontes.

SOUSA, Maurílio Antônio Dias de (2009). A Estrella da Poesia: impressões de uma trajetória. Dissertação (Mestrado em Letras e Lingüística). Instituto de Letras, Universidade Federal da Bahia, Bahia.

SOUZA, Eneida Maria de (2002). Os livros de cabeceira da crítica. In: Crítica cult. Belo Horizonte: Editora UFMG.

SOUZA, Liêdo Maranhão de (1976). Classificação popular da literatura de cordel. Petrópolis: Vozes.

SOUZA, Roberto Acízelo de (2013). A crítica literária no Brasil Oitocentista: um panorama. Rogério Cordeiro et al (org.). A crítica literária brasileira em perspectiva. Cotia, São Paulo: Ateliê Editorial.

SPENGLER, Oswald (1964). A decadência do Ocidente. Rio de Janeiro: Zahar.

SPIVAK, Gayatri Chakravorty (2003). ¿Puede hablar el subalterno?. Revista Colombiana de Antropología. Bogotá, n. 39, p. 297-364.

STEGAGNO-PICCHIO, Luciana (1997). História da literatura brasileira. Rio de Janeiro: Nova Aguilar.

SÜSSEKIND, Flora (1993). Papéis colados. Rio de Janeiro: Editora da UFRJ.

SWAIN, Tânia Navarro (2000). A invenção do corpo feminino ou a hora e a vez do nomadismo identitários. Textos de História, Brasília, v. 8, n. 1/2, p. 47-86.

TERRA, Ruth Brito Lemos (1983). Memória de lutas: literatura de folhetos do Nordeste (1893-1930). São Paulo: Global.

(s.d.). Coletânea de poesia popular nordestina. Revista do Departamento de Extensão Cultural e Artística, ano 4. Recife: EFPE.

THOMPSON, Edward Palmer (1987[1963]). A formação da classe operária inglesa, v. 3. Rio de Janeiro: Paz e Terra.

TINHORÃO, José Ramos (2004). Domingos Caldas Barbosa: o poeta da viola, da modinha e do lundu (1740-1800). São Paulo: Editora 34.

TOCQUEVILLE, Alexis de (1987). A democracia na América. 4ª ed. Belo Horizonte: Itatiaia.

TRAVESTHRILLER (2015). Direção: Orlando Pereira e Nivea Uchôa. 28 min. Disponível em: <https://www.youtube.com/watch?v=kMSp9KUn1mg>. Acesso em: 3 mar. 2015. 
VARNHAGEN, Francisco Adolfo de (1850). Florilégio da poezia brazileira. Tomo II, Lisboa: Imprensa Nacional.

VASCONCELOS, Carolina Michaëlis de (1990). Cancioneiro da ajuda. Lisboa: Imprensa Nacional, Casa da Moeda.

VERÍSSIMO, José (1916). História da literatura brasileira. Disponível em: <http://www.psb40.org.br/bib/b248.pdf>. Acesso em: 3 maio, 2012.

(1969). Publicistas, oradores, críticos. In: . História da Literatura

Brasileira [1916]. 5. ${ }^{\mathrm{a}}$ ed. Rio de Janeiro: José Olympio.

(1998). História da literatura brasileira: de Bento Teixeira (1601) a Machado de Assis (1908). Brasília: Editora Universidade de Brasília.

VIANA, Antonio Klévisson (2007). Klévisson Viana. José Neumanne (Introdução e Seleção). São Paulo: Hedra (Coleção Biblioteca de Cordel).

VICENTE, Zé [Lindolfo Marques de Mesquita] (2005). Zé Vicente. Vicente Salles. (Introdução e Seleção). São Paulo: Hedra (Coleção Biblioteca de Cordel).

VIVEIROS DE CASTRO, Eduardo (1996). Os pronomes cosmológicos e o perspectivismo ameríndio. Mana, Rio de Janeiro, v. 2, n. 1.

(2002). O nativo relativo. Mana. Rio de Janeiro, v. 8, n. 1.

WATT, Ian (1996). A ascensão do romance: estudos sobre Defoe, Richardson e Fielding. Tradução de Hildegard Feist. São Paulo: Companhia das Letras.

WEBER, João Hernesto (2009). Tradição literária \& tradição crítica. Porto Alegre:

Movimento.

WHITE, Hayden (2001). O texto histórico como artefato literário. In: Trópicos do discurso: ensaios sobre a crítica da cultura. Tradução de Alípio de França Neto. $2^{\mathrm{a}}$ ed. São Paulo: EDUSP.

WOLF, F.A. (1988 [1795]). Prolegomena ad Homerum, Halle: Princeton.

ŽIŽEK, Slavoj (2007). Um mapa da ideologia. Tradução de César Benjamin. Rio de Janeiro: Contraponto.

ZUMTHOR, Paul (1993). A letra e a voz na literatura medieval. São Paulo: Companhia das Letras. 